\title{
Aplicações de Processamento e Análise Avançada de Imagens para a Caracterização de Imagens de Microscopia de Força Atômica
}

\author{
Carlos Alberto Rodrigues
}

Tese apresentada ao Instituto de Física de São Carlos, da Universidade de São Paulo, para obtenção do título de Doutor em Ciências: Física Aplicada, sub-área: Física Computacional.

Orientador: PROF. Dr. LuCiAnO DA Fontoura CoStA Co-orientador: Prof. Dr. Roberto MEndonçA FARIA

São Carlos

2003 
Dedico esta tese à minha esposa Rosalina e à minha mãe Lúcia pelo amor, compreensão e apoio. 


\section{Agradecimentos}

Primeiramente a Jeová Deus por me ter dado a vida, forças para realizar este trabalho e uma esperança para o futuro;

Ao meu orientador Prof. Luciano da Fontoura Costa pelas enriquecedoras discussões, consideração, paciência e apoio em todas as situações;

Ao meu co-orientador Prof. Roberto Mendonça Faria, por me ter dado apoio desde o início da pós-graduação e pelos muitos ensinamentos;

Ao Prof. Osvaldo Novaes Oliveira Jr. pela atenção e apoio que resultou numa frutífera colaboração;

Ao Prof. Marcelo Pereira da Silva, pela parceria desde o início e que resultou em muitas discussões vitais relacionadas ao AFM;

Ao Prof. Sergei Sheyko pela acolhida hospitaleira e pela oportunidade de trabalhar com o seu grupo;

A Nara Souza, Ivan Bechtold, Alexandre Marletta e Letícia Vega pela colaboração e pelo que aprendi nas muitas discussões;

Aos amigos do grupo de Visão Cibernética: Leandro Estrozi, Edson Nakamura, Silvia Cristina, Andrea Bianchi, Daniela Sabino, Li Zhaohui, Ricardo Fabbri, Renata Arantes, Leandro Carrijo, Bruno Travençolo, Luis Consularo, Luis Rios que de uma forma ou de outra me ajudaram nestes anos e pela agradável companhia;

A Mara, Neuza, Betânia e todos da biblioteca do IFSC pela atenção impecáveis;

Ao Marquinhos, Cláudia e Sueli que sempre me auxiliaram com toda a disposição;

A Wladerez e todos da secretaria que sempre me atenderam com toda a atenção;

Ao IFSC-USP e ao DC-UNC at Chapel Hill-EUA pela estrutura e a FAPESP pela bolsa de Doutorado Direto. 


\section{Conteúdo}

1 Introdução $\quad 1$

2 Microscopia de Força Atômica $\quad 6$

2.1 Introdução . . . . . . . . . . . . . . . . . . . . . . 6

$2.2 \mathrm{O} \mathrm{AFM} \ldots \ldots \ldots \ldots \ldots$

2.3 Modos de operação . . . . . . . . . . . . . . . . . . . . . . . . . 8

2.3.1 Modo Contato . . . . . . . . . . . . . . . . . . 8

2.3.2 Modo não contato . . . . . . . . . . . . . . . . . . . 10

2.3.3 Modo contato intermitente (tapping) . . . . . . . . . . 11

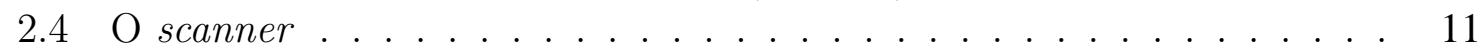

2.4.1 Design do scanner e operação . . . . . . . . . . . . . . . . 12

2.4.2 Não linearidades do scanner . . . . . . . . . . . . . . . . . . . . . . . . . . 13

2.4.3 Arrasto (creep) . . . . . . . . . . . . . . . . . . . 17

2.4.4 Acoplamento cruzado (bow) . . . . . . . . . . . . 20

2.5 Sondas . . . . . . . . . . . . . . . . . . . . 23

2.6 Aplicações em polímeros . . . . . . . . . . . . . . . . . . 25

2.6.1 Imagens de AFM de polímeros orientados . . . . . . . . . . . 26

3 Processamento e Análise de Imagens em SPM 29

3.1 O uso de softwares de análise e processamento de imagens . . . . . . . . . . . . . . . . . . . 29

3.2 Algoritmos de análise e processamento de imagens . . . . . . . . . . . . 29

3.2.1 Processamento de Imagens . . . . . . . . . . . . . . . . . . . . 30

3.2.2 Análise de Imagens . . . . . . . . . . . . . . . . . . . . . . . 32

3.3 Softwares para microscopia de varredura por sonda . . . . . . . . . . 33

3.3.1 Não comerciais (freewares) . . . . . . . . . . . . . . . . . 34

3.3.2 Comerciais . . . . . . . . . . . . . . . . 37

4 Process. de Imagens de superfícies para alinhamento... 39

4.1 Introdução . . . . . . . . . . . . . . . . . . . . . . 39

4.2 Materiais e métodos . . . . . . . . . . . . . . . . . 40

4.2.1 Tratamento de superfícies . . . . . . . . . . . . . . . 40

4.2.2 Técnicas experimentais . . . . . . . . . . . . . . . 41

4.2.3 Determinação da energia de ancoramento . . . . . . . . . . . . . 41

4.2.4 Processamento das imagens . . . . . . . . . . . . . . . . 43

4.3 Resultados experimentais e discussão . . . . . . . . . . . . . . . . . . . . 49

4.4 Conclusões . . . . . . . . . . . . . . . . . . . . . 56 
5 Caracteriz. da morfologia de filmes LBL POMA/PVS 59

5.1 Introdução . . . . . . . . . . . . . . . . . . . . . . . . . . . . . . . . 59

5.2 Análise de imagens de AFM de filmes LBL POMA/PVS . . . . . . . . 61

5.2.1 Determinação das coordenadas dos picos . . . . . . . . . . 61

5.2 .2 Dilatações exatas . . . . . . . . . . . . . . . . . . 62

5.2 .3 Diagramas de Voronoi . . . . . . . . . . . . . . . . . . 65

5.3 Aplicações . . . . . . . . . . . . . . . . . . . . . . . . . . . . . . 67

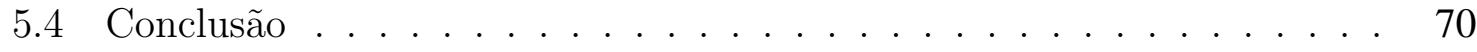

6 Análise do aumento de PL em filmes PPV 72

6.1 Introdução . . . . . . . . . . . . . . . . . . . . . . 72

6.2 Aumento da luminescência em filmes PPV . . . . . . . . . . . . . 73

6.3 Parte experimental . . . . . . . . . . . . . . . . . . . . . . . 74

6.3 .1 Preparação do substrato . . . . . . . . . . . . . . . . 74

6.3 .2 Obtenção da grade . . . . . . . . . . . . . . . . . . . . . 74

6.4 Análise das imagens . . . . . . . . . . . . . . . . . . . . . . 75

6.4 .1 Primeiros vizinhos . . . . . . . . . . . . 76

6.4 Transformada de Fourier 2D . . . . . . . . . . . . . 76

6.4.3 Densidade espectral de potência . . . . . . . . . . . . . . 77

6.4.4 Filtragem por Fourier . . . . . . . . . . . . . . . . . 78

6.5 Resultados e discussão . . . . . . . . . . . . . . . . . . . . . . . 80

6.6 Conclusão . . . . . . . . . . . . . . . . . . . . . . . . . . . . . . 89

7 Curvatura espontânea de brushes de polímeros 90

7.1 Introdução . . . . . . . . . . . . . . . . . . . . . . . . . . . 90

7.2 Algoritmos envolvidos . . . . . . . . . . . . . . . . . 91

7.2 .1 Extração do contorno . . . . . . . . . . . . . . . . . . . . 91 91

7.2 .2 Transformada Distância . . . . . . . . . . . . . . . . 93

7.2 .3 Esqueletização . . . . . . . . . . . . . . . . . . . . . . . . . 999 94

7.2 .4 Curvatura . . . . . . . . . . . . . . . . . . . . . . 97

7.3 Procedimento para obtenção da curvatura das macromoléculas . . . . . 102

7.4 Parte experimental . . . . . . . . . . . . . . . . . . . . 112

7.4 .1 Materiais . . . . . . . . . . . . . . . . 112

7.4 .2 Caracterização . . . . . . . . . . . . . . . . . . 112

7.4 .3 Preparação das amostras . . . . . . . . . . . . . . . . 113

7.4.4 Microscopia de força atômica . . . . . . . . . . . . . . . 113

7.5 Resultados e discussão . . . . . . . . . . . . . . . . . . . . . . . 113

7.6 Conclusão . . . . . . . . . . . . . . . . . . . . . . . . . . . 118

8 Conclusão e comentários finais 119

8.1 Introdução . . . . . . . . . . . . . . . . . . . . . . . . . . . . . . . 119

8.2 Conclusões . . . . . . . . . . . . . . . . . . . . . . . . . . . . . . . . . . . . . . . 119

8.3 Contribuições da tese e desenvolvimentos futuros . . . . . . . . . . 123

$\begin{array}{ll}\text { Bibliografia } & 125\end{array}$ 
$\begin{array}{lr}\text { A O software SPIA } & 134\end{array}$

A.1 Menu File . . . . . . . . . . . . . . . . . . . . . . . . . . . . 135

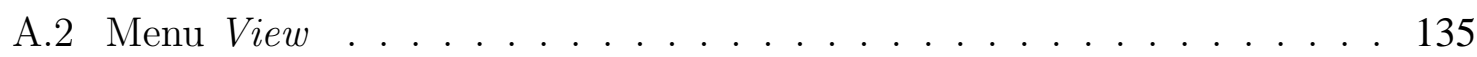

A.3 Menu Analyze . . . . . . . . . . . . . . . . . . . 135

A.4 Menu Modify ... . . . . . . . . . . . . . . . . . 136

A.5 Menu Windows . . . . . . . . . . . . . . . . . . . 136

B Formato do arquivo do Nanoscope III 137

B.1 Organização geral do arquivo . . . . . . . . . . . . . . . . . 137

B.2 Convertendo os dados da imagem em alturas . . . . . . . . . . . . . . 138

B.2.1 Calculando os valores para as versões $4.3 \mathrm{x}$ e $4.4 \mathrm{x}$. . . . . . . . 139 


\section{Lista de Figuras}

2.1 Sistema do AFM. . . . . . . . . . . . . . . . . . . . 7

2.2 Força interatômica vs. distância [18] . . . . . . . . . . . . . . 8

2.3 Varredura do scanner do AFM da Park Intruments. [18] . . . . . . . . 12

2.4 Tubo do scanner [18]. . . . . . . . . . . . . . . . . . . . . . . 13

2.5 Não linearidade intrínseca do scanner [18] . . . . . . . . . . . . . . . . 14

2.6 Histerese do scanner [28]. . . . . . . . . . . . . . . . . . . . 15

2.7 Efeito da histerese em imagens de $100 \mu m \times 100 \mu m$, nas direções de traço e retraço $[28] . \ldots \ldots \ldots \ldots \ldots \ldots$

2.8 Histerese na altura $[18] . \ldots \ldots \ldots$

2.9 Deformação das cerâmicas com o tempo, em função da voltagem aplicada. 17

2.10 Creep de um scanner [18] . . . . . . . . . . . . . . . . . . . . . . 18

2.11 Creep na direção $z[18] \ldots \ldots$. . . . . . . . . . . . . . . . . . . . . . . . . 19

2.12 Creep na direção $z[28] \ldots \ldots \ldots$. . . . . . . . . . . . . . . . 20

2.13 Movimento do scanner com acoplamento cruzado [18]. . . . . . . . . . 21

2.14 Efeitos do acoplamento cruzado sobre um degrau [18] . . . . . . . . . . 21

2.15 Efeitos combinados de histerese, creep e acoplamento cruzado em um

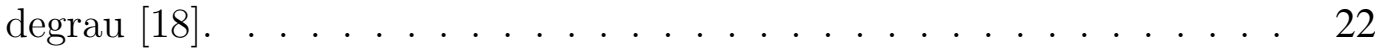

2.16 Esquema do efeito da ponta do AFM sobre a imagem da amostra: (a) Superfície da amostra, (b) perfil da imagem da superfície, dilatada pela

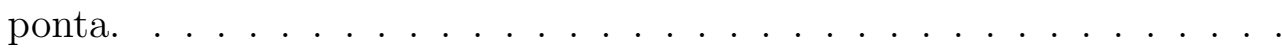

2.17 (a) Imagem de AFM mostrando o empacotamento de cadeias sobre a superfície de PE cold-extruded. (b) Zoom da figura(a). A periodicidade de $0.25 \mathrm{~nm}$ ao longo da imagem corresponde a conformação trans das

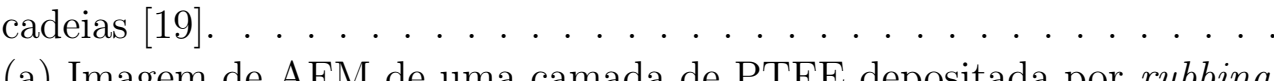

2.18 (a) Imagem de AFM de uma camada de PTFE depositada por rubbing em um substrato de vidro. (b) Vista da superfície da figura (a) após filtragem. (c) Esquema mostrando a cadeia helicoidal 136 de PTFE [19].

4.1 Esquema experimental para determinação da energia de ancoramento azimutal. . . . . . . . . . . . . . . . . . . .

4.2 Representação dos processos (retângulos) e dados (caixas arredondadas) envolvidos na análise dos canais superficiais estudados. . . . . . . . . .

4.3 Segmentação das imagens de AFM. Esquerda: Imagem original. Direita: Canais segmentados. Varredura: $3 \times 3 \mu m^{2}$. . . . . . . . . . .

4.4 (a) Região $3 \times 3$ da imagem; (b) máscara usada para calcular $\partial g / \partial x$; (c) Máscara usada para calcular $\partial g / \partial y$. Estas máscaras são conhecidas como operadores de Sobel. . . . . . . . . . . . . . . . . . . . . . . 
4.5 Imagens das superfícies. (a) PVA, (b) PMMA, (c) Teflon. . . . . . . . .

4.6 Orientações dos canais nos substratos em imagens de AFM. PMMA 3x e 6x representam quantas vezes foi efetuado o processo de esfregamento.

4.7 Representação em histogramas. (a) Distribuição das alturas ao longo dos canais, em tons de cinza; (b) orientação interna dos canais. O ângulo refere-se a orientação do vetor gradiente de cada pixel ao longo dos canais com o plano horizontal. . . . . . . . . . . . . . . . 52

4.8 Distâncias entre os sulcos, em unidades de pixels. . . . . . . . . . . . 53

4.9 Textura do cristal líquido sobre os substratos estudados: PVA, PMMA e Teflon. À esquerda: Imagens originais obtidas por microscopia óptica. À direita: Imagem limiarizada. Varredura: 1 x $1 \mathrm{~mm}^{2}$. . . . . . . . . 54

4.10 Corte transversal aos canais dos filmes de Teflon, nas imagens de AFM. 57

5.1 Imagem de AFM do filme POMA/PVS. Varredura: 1 x $1 \mu \mathrm{m}^{2} \ldots \ldots$. . . 61

5.2 Três cortes na imagem. (a) Limiar 240, 7 componentes conexos, (b) Limiar 210, 29 componentes conexos, (c)Limiar 194, 55 componentes conexos. . . . . . . . . . . . . . . . . . .

5.3 Contagem dos picos na imagem. Para 100 cortes, foram encontrados 366 picos, para um tempo de processamento de 5 minutos (Pentium III,

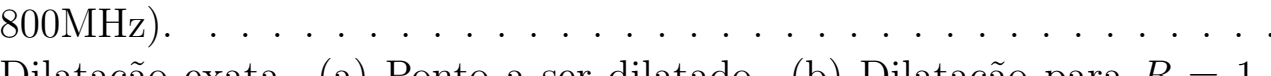

5.4 Dilatação exata. (a) Ponto a ser dilatado. (b) Dilatação para $R=1$. (c) Dilatação para $R=\sqrt{(2)}$. (d) Dilatação para $R=2$. . . . . . . . .

5.5 (a) Contagem dos glóbulos. (b) Diagrama de Voronoi. Cada região possui um tom de cinza diferente. Varredura: $2 \times 2 \mu \mathrm{m}^{2}$. . . . . . . .

5.6 (a) Uma imagem contendo vários objetos conexos. (b) Diagrama generalizado de Voronoi. . . . . . . . . . . . . . . . . . . . . . . 66

5.7 Superposição da imagem original de POMA e seu respectivo diagrama de Voronoi. . . . . . . . . . . . . . . . . . . . . . .

5.8 Imagens de AFM de filmes LBL com uma camada de POMA adsorvida sobre 10 bicamadas de POMA/PVS, sendo que cada camada foi adsorvida com um tempo de 3 min. O tempo de adsorção para a $11^{a}$ camada de POMA foi de 30 min. A concentração da solução foi (a) $0.03 \mathrm{~g} / \mathrm{L}$, (b) $0.3 \mathrm{~g} / \mathrm{L} \mathrm{e} \mathrm{(c)} 0.6 \mathrm{~g} / \mathrm{L} \ldots \ldots \ldots \ldots$

5.9 Esquerda: Imagens de AFM $\left(500 \times 500 \mathrm{~nm}^{2}\right)$ para filmes POMA/PVS adsorvidos de soluções de POMA com três concentrações: $0.6,0.3$ e $0.03 g / l$. Meio: Perfil transversal das imagens. Direita: Distribuição dos raios dos glóbulos. . . . . . . . . . . . . . . . . .

6.1 Aparato experimental para a obtenção da grade. . . . . . . . . . . . 75

6.2 Imagem de AFM e sua DEP. Varredura: 500x500 $\mu m^{2}$. . . . . . . . . 78

6.3 Baixas frequências da DEP selecionadas e sua transformada inversa. . . 79

6.4 Eliminação das baixas frequências, filtro passa alta. . . . . . . . . . . . 80

6.5 Imagem óptica da região irradiada (I) e não irradiada (NI) . . . . . . . . . 81

6.6 Espectros de PL (300 K), antes (0 min.) e depois (35 min.) da exposição à radiação de um filme PPV sob condições atmosféricas, em unidades aleatórias. 
6.7 Imagem de AFM no modo tapping das regiões não irradiada (a) e irradiada (b). Os dois glóbulos na região não irradiada são defeitos gerados no processo de conversão térmica para a obtenção do PPV. Varredura: $10 \times 10 \mu m^{2}$

6.8 Distribuição das alturas de todos os pixels da imagem (512x512 alturas, em cada caso).

6.9 Distribuição dos picos contados, após 150 cortes na imagem. Região não irradiada: 3209 picos. Região irradiada: 16151 picos. . . . . . . . . . . 84

6.10 Distâncias entre os 100 primeiros picos vizinhos. . . . . . . . . . . . . . 85

6.11 (a) Imagem da grade de difração. (b) A mesma imagem equalizada. Varredura: $25,58 \mu m^{2}$. . . . . . . . . . . . . . . . . 86

6.12 Imagem da DEP da grade. . . . . . . . . . . . . . . . . . . . 87

6.13 (a) Seleção das frequências da grade. (b) Transformada inversa. Ondulações provocadas pela difração do laser. . . . . . . . . . . . . . . .

6.14 (a) Perfil da imagem da figura 6.11(a). (b) Perfil da imagem da figura 6.13(b). Há superposição de frequências visto que ocorreu a seleção de mais de uma frequência. . . . . . . . . . . . . . . . . . . .

7.1 A curvatura espontânea de uma brush cilíndrica adsorvida em uma superfície plana pode ser induzida pela redistribuição das cadeias laterais relativas à backbone. . . . . . . . . . . . . . . . . . . . . 99 91

7.2 Esquema para o algoritmo de perseguição de contorno. . . . . . . . . . 92

7.3 Vizinhança de oito para o pixel $\mathrm{P}$ do contorno. . . . . . . . . . . . . . . 93

7.4 Distância d $(\mathrm{P}, \mathrm{C})$. . . . . . . . . . . . . . . . . . . . . 93

7.5 Objeto e visualização de sua transformada distância. . . . . . . . . . . . 94

7.6 Retângulo e seu esqueleto. . . . . . . . . . . . . . . . . . . . . . 95

7.7 Histograma dos raios necessários para a reconstrução do retângulo da figura $7.6 \ldots \ldots \ldots$. . . . . . . . . . . . . . . . . 96

7.8 (a) Pixels do contorno. (b) Contorno rotulado. (c) Propagação dos rótulos. 97

7.9 (a) Contorno. (b) Transformada Distância. (c) Rótulos propagados. (d) Imagem das diferenças. . . . . . . . . . . . . . . . . . . . . . . . . . 98

7.10 (a) e (b) Reconstrução para limiar 20. (c) e (d) Reconstrução para limiar 120. . . . . . . . . . . . . . . . . . . 99

7.11 Contorno e encolhimento após filtragem. . . . . . . . . . . . . . . 101

7.12 (a) Imagem de brushes. (b) Imagem limiarizada, limiar $=130$. Varredura: $1 \mathrm{x} 1 \mu \mathrm{m}^{2} \ldots \ldots \ldots \ldots . \ldots \ldots 3$

7.13 Esqueletos das brushes. . . . . . . . . . . . . . . . . . . 104

7.14 Situações de uma vizinhança. O pixel analisado é o central. Neste caso trata-se de uma extremidade. . . . . . . . . . . . . . . . . . . . . . . 104

7.15 Situações de duas vizinhanças. Os vizinhos são vizinhos entre si. O pixel central é extremidade. . . . . . . . . . . . . . . . . . . . . . . . 104

7.16 Os pontos de junção possuem ao menos três vizinhos que não são vizinhos entre si. . . . . . . . . . . . . . . . . . . 105

7.17 Nestes casos os pixels do centro são eliminados por serem irrelevantes. . 105

7.18 Situação dos esqueletos após a eliminação dos ramos pequenos. . . . . . 106 
7.19 Após a eliminação dos esqueletos com mais de três pontas, restam apenas as backbones. . . . . . . . . . . . . . . . . . . 107

7.20 Todos os pixels das backbones foram dilatados em um pixel de cada lado. 108

7.21 Semi-círculos de raios 25, 40 e 60, respectivamente. . . . . . . . . . 108

7.22 Curvatura total do contorno do semicírculo de raio 60. . . . . . . . . 109

7.23 Histograma das curvaturas. . . . . . . . . . . . . . . . . . . . . 110

7.24 Intervalos em vermelho, $(0<k<0.01)$ e em azul, $(k>0.01) \ldots \ldots .111$

7.25 Grau de polimerização $=9$. (a) Antes da compressão (b) Após a expansão. Varredura: $1 \times 1 \mu \mathrm{m}^{2} \ldots \ldots \ldots \ldots \ldots$. . . . . . . . 114

7.26 Grau de polimerização $=27$. (a) Antes da compressão (b) Após a expansão. Varredura: $1 \times 1 \mu \mathrm{m}^{2} \ldots \ldots \ldots \ldots \ldots \ldots$

7.27 Grau de polimerização $=35$. (a) Antes da compressão (b) Após a expansão. Varredura: $1 \times 1 \mu \mathrm{m}^{2} \ldots \ldots \ldots \ldots \ldots \ldots$

7.28 Grau de polimerização $=51$. (a) Antes da compressão (b) Após a expansão. Varredura: $1 \times 1 \mu \mathrm{m}^{2} \ldots \ldots \ldots \ldots$. . . . . . . . 117

A.1 Interface do SPIA. . . . . . . . . . . . . . . . . . . . . . . 134

B.1 Estrutura do arquivo de dados da imagem (Nanoscope Command Reference Manual). . . . . . . . . . . . . . . . . . . . . . . 138 


\section{Lista de Tabelas}

4.1 Medidas das orientações dos canais. . . . . . . . . . . . . . . 51

4.2 Energia de ancoramento para os substratos PMMA e Teflon . . . . . . 55

5.1 Estrutura de dados SEDR. . . . . . . . . . . . . . . . . . 65

5.2 Análise quantitativa das imagens de AFM. São apresentados o número dos glóbulos, raio máximo, mínimo e médio dos glóbulos, rugosidade RMS, para as três concentrações. . . . . . . . . . . . . . . . . 71

7.1 Raio 25. Curvatura exata $=0,04 \ldots \ldots \ldots \ldots \ldots$

7.2 Raio 40. Curvatura exata $=0,025 \ldots \ldots \ldots \ldots \ldots \ldots$

7.3 Raio 60. Curvatura exata $=0,0168 \ldots \ldots \ldots \ldots \ldots$

7.4 Pesos moleculares das brushes por MALLS-GPC. . . . . . . . . . . . 112

7.5 Largura da gaussiana. . . . . . . . . . . . . . . . . . . . . . 118 


\section{Lista de Abreviaturas e Símbolos}

- SPIA - Scanning Probe Image Analysis

- SPM - Scanning Probe Microscopy

- AFM - Atomic Force Microscopy

- STM - Scanning Tunelling Microscopy

- CL - cristais líquidos

- PTFE - politetrafluoroetileno

- PP - polipropileno

- PVA - polivinil alcool

- PMMA - polimetil metacrilato

- PE - polietileno

- LBL - Layer-by-layer

- POMA - poli(o-metoxianilina)

- PVS - ácido polivinil sulfônico

- PPV - poli(p-fenileno vinileno)

- PL - fotoluminescência

- PTHT - poli(cloreto de xilideno tetrahidrotiofeno)

- pBPEM - poli(metacrilato de 2-(2-bromo propioniloxi)etila)

- DFT - transformada discreta de Fourier

- DEP - densidade espectral de potência

- I - Irradiada

- NI - Não irradiada

- PBA - poli-butil acrilato 
- ATRP - Polimerização radicalar por trasferência de átomos (Atom Transfer Radical Polimerization)

- GPC - Cromatografia de permeação em gel

- BMP - Bit - Map, formato de imagem

- Pixel - Picture Element

- ASCII - American Standard Code for Information Interchange

- POO - Programação Orientada a Objetos

- MDI - Multiple Document Interface 


\section{Resumo}

Esta tese aborda a aplicação de técnicas avançadas de processamento e análise de imagens em problemas originais envolvendo imagens de microscopia de força atômica. Para isso, foi desenvolvida uma série de algoritmos para a caracterização e o entendimento do processo de formação de novos materiais poliméricos com perspectivas de inúmeras aplicações tecnológicas. As análises envolveram a determinação da orientação da morfologia de substratos para alinhamento de cristais líquidos, contagem e estimativa dos raios de domínios em filmes automontados POMA/PVS, análise do aumento da fotoluminescência em filmes PPV e estudos da curvatura espontânea de macromoléculas de polímeros. Dentre os algoritmos principais podemos citar a determinação da inclinação dos autovalores da matriz de covariância das coordenadas dos pontos da forma, aplicação da técnica dos máximos regionais e diagramas de Voronoi, filtros passabanda 2D através da transformada de Fourier e extração da curvatura multiescala. A implementação destes algoritmos envolveu algoritmos básicos de análise de imagens tais como esqueletização, dilatações exatas e extração do contorno de formas. A principal contribuição deste trabalho foi a implementação do software denominado SPIA (Scanning Probe Image Analysis) que possui ferramentas para análise e processamento de imagens incluindo todas as que foram utilizadas no decorrer deste trabalho além de outras ferramentas. Este software foi desenvolvido em ambiente Delphi sob o paradigma da orientação a objetos para plataformas Windows NT/9X/2000/XP. Possui uma interface amigável e semelhante a outros softwares dedicados a processamento de imagens. Todas as técnicas aplicadas foram testadas extensivamente e os resultados que corroboram sua eficiência são mostrados ao longo da tese. 


\section{Abstract}

This thesis address the application of advanced techniques of processing and analysis of images in original problems involving images of atomic force microscopy. For this, a series of algorithms for characterization and understanding of process of formation of new polymeric materials was developed and implemented, with perspectives of many technological applications. The analysis was applied to the determination of orientation of the morphology of substrates for alignment of liquid crystals, counting and estimative of radiuses of granules in layer-by-layer polymer films, analysis of enhancement of photoluminescence in PPV cast films, as well as the study of curvature spontaneous of macromolecules. The principal algorithms included are determination of inclination of eigenvectors of matrix of covariance of coordinates of points of shape, application of regional maxima technique and Voronoi diagrams, passband filters 2D through Fourier Transform and curvature multiscale. The implementation of these algorithms involved a series of image analysis algorithms such as squeletonization, exact dilations and extracting of contour of shapes. The principal contribution of this work was to develop a software called SPIA (Scanning Probe Image Analysis) that includes tools for analysis of processing of images including that were used in this work. This software was developed in Delphi under object orientation paradigm to Windows NT/9X/2000/XP. It has a friendly interface similar to other image processing softwares. All this techniques were tested extensively and the results that corroborate the robustness of the algorithms are included throughout the thesis. 


\section{Capítulo 1}

\section{Introdução}

A área de processamento de imagens tem progredido continuamente. Compreende diversos métodos com o objetivo de melhorar a informação contida na imagem para a devida interpretação. Muitas vezes, fala-se de processamento e análise de imagens como uma mesma área, mas convém que façamos uma distinção. A análise de imagens engloba todas as medidas que são feitas nas imagens, que de outra forma não seria possível, ou muito difícil para o homem fazer. Seguindo esta tendência, quando estivermos falando de processamento, também estaremos incluindo análise de imagens.

A aplicação destas áreas é tão vasta quanto se possa imaginar. Onde quer que se usem imagens, alguma forma de processamento e análise eventualmente terá de ser feita. Por exemplo, na medicina o processamento é feito para melhorar o contraste ou o nível de intensidade das cores para uma melhor interpretação das imagens de Raios-X e outras imagens biomédicas. Geógrafos usam a mesma técnica ou similar para estudar padrões de poluição em imagens aéreas ou de satélite. $\mathrm{Na}$ arqueologia, métodos de processamento de imagens restauraram com sucesso imagens borradas que eram os únicos registros de artefatos raros perdidos ou danificados após serem fotografados. Na Física e em outros campos relacionados, as técnicas computacionais fazem contínuos melhoramentos em áreas tais como plasmas de alta energia e microscopia. Similarmente, técnicas bem sucedidas de análise e processamento podem ser encontradas em astronomia, biologia, medicina nuclear, defesa e aplicações industriais. 
A interdisciplinaridade é uma característica marcante desta área, pois o processamento das imagens envolverá conhecimento do problema em que a aplicação está sendo feita. Além disso, o desenvolvimento dos algoritmos requer conhecimentos de linguagens de computação, física e matemática, necessários para a implementação dos mesmos.

Com a invenção do Microscópio de Varredura por Sonda (SPM, Scanning Probe Microscopy), que conferiu o prêmio Nobel de Física de 1986 a Binnig e Rohrer [1], surgiu mais uma área na microscopia para a aplicação das técnicas de processamento de imagens. Em 1986, Binnig, Quate e Gerber inventaram o Microscópio de Força Atômica (AFM) [2] , que pode produzir imagens de superfícies não condutoras e condutoras em escala nanométrica. Isto abriu uma gama de aplicações muito grande, especialmente em Ciência dos Materiais.

A partir de então, um número cada vez maior de grupos de pesquisa tem utilizado este equipamento para ter uma compreensão mais detalhada das propriedades dos novos materiais. No entanto, nota-se através da literatura que a maioria dos trabalhos envolvendo imagens de polímeros através do AFM, restringe-se somente a uma análise visual. Este tipo de abordagem além de qualitativa é limitada pelo fato de que muitas vezes a simples inspeção visual pode levar a conclusões totalmente contrárias à realidade. A utilização de algoritmos apropriados para análise de imagens existe mas observa-se que é restrita a poucos grupos de pesquisa.

Por outro lado o Instituto de Física de São Carlos, possui a infra-estrutura necessária para esta interação. O Grupo de Polímeros Bernard Gross (GPBG) conta com um AFM que tem servido a diversas pesquisas realizadas neste Instituto. Inserido também neste Instituto está o grupo de pesquisa em Visão Cibernética que ao longo dos anos vem adquirindo experiência em abordagens multidisciplinares envolvendo visão computacional e biológica, neurociência matemática e computacional, análise e processamento de imagens. Dessa interdisciplinaridade inerente e sólida infra estrutura existente em nosso Instituto surgiu esse trabalho de pesquisa que visa a aplicação e desenvolvimento de técnicas avançadas de análise e processamento de imagens no grupo de Visão Cibernética em imagens geradas pelos grupos de 
pesquisa do GPBG. No decorrer de nosso trabalho outros grupos de Polímeros em outras Instituições também passaram a fazer colaboração conosco.

As interações com os grupos de polímeros ocorreram através de diversas reuniões, realizadas em nosso instituto ou junto aos outros grupos, onde se discutiu o problema e escolha da metodologia a ser adotada. Nestas reuniões as imagens foram apresentadas e o problema físico foi discutido, para que pudéssemos ter uma compreensão razoável do problema. As medidas nas imagens foram sugeridas levando-se em consideração a sua relevância para o trabalho e sua viabilidade computacional. Depois de definida a metodologia os algoritmos foram desenvolvidos e os resultados apresentados aos grupos de polímeros. Dependendo de sua eficiência em descrever a morfologia do filme, foram aceitos ou alterados para o melhoramento das medidas.

A principal contribuição deste trabalho é o desenvolvimento de um software de processamento e análise de imagens que reúne todas as técnicas que foram desenvolvidas ao longo da pesquisa. O software denominado SPIA (Scanning Probe Image Analysis) foi desenvolvido no ambiente Delphi de programação sob o paradigma da programação orientada a objetos (POO). Possui uma interface amigável, semelhante aos softwares voltados para o processamento de imagens. Ao final deste trabalho, este software torna-se disponível aos grupos de pesquisa deste Instituto para que possa auxiliar na análise de suas imagens.

Nesta tese não serão discutidos os princípios básicos de processamento e análise de imagens digitais. Estes conceitos são muito bem explorados em referências básicas tais como $[3,4,5,6,7,8]$. Sendo assim, os capítulos 2 e 3 introduzem a microscopia de Força Atômica e a análise e processamento de imagens aplicadas e imagens de AFM. Os capítulos seguintes irão se concentrar nos trabalhos desenvolvidos em colaboração com outros grupos de polímeros. Deste modo, cada um destes capítulos trará uma explanação dos algoritmos desenvolvidos para o processamento e análise das imagens, detalhes sobre o desenvolvimento do trabalho, discussão dos resultados e uma conclusão. Caso um algoritmo seja usado em mais de um capítulo, será citado o capítulo em que o algoritmo é explanado. A seguir, serão 
comentados brevemente o conteúdo dos próximos capítulos.

O capítulo 2 traz uma visão geral do princípio de funcionamento do Microscópio de Força Atômica (AFM) e seus modos de operação. Este capítulo se concentra nos aspectos críticos da formação da imagem, no que diz respeito à geração de ruídos e distorções. Neste aspecto, destaca-se a não-linearidade do scanner e dilatação da imagem provocada pela sonda. No final é apresentado um exemplo de como o AFM tem sido usado para a caracterização de polímeros.

Foi feita uma revisão bibliográfica sobre o desenvolvimento de softwares específicamente para a análise e o processamento de imagens de AFM e o resultado é mostrado no capítulo 3. Alguns são de aplicação geral e outros são mais específicos, dependendo da pesquisa para a qual o software foi desenvolvido. Dentre esses softwares, bem poucos são freeware. A maioria não foi disponibilizada para uso de outros pesquisadores ou então são vendidos mediante uma licença, dificultando que outros pesquisadores que não tenham intercâmbio com pessoas da área de processamento de imagens possa fazer um estudo quantitativo de suas imagens. Um aspecto importante que se destaca neste capítulo é a necessidade de se fazer um processamento nas imagens para corrigir as distorções geradas pelo scanner e pela sonda. Nos trabalhos apresentados nesta tese, este processamento foi feito através do software que faz parte do sistema do AFM da Digital Instruments, Nanoscope III.

O capítulo 4 descreve o primeiro trabalho realizado, em colaboração com o IF/USP. O objetivo é estudar superfícies de amostras usadas para o alinhamento de cristais líquidos. Para isso as imagens foram analisadas para descrever a orientação obtida após um processo de alinhamento e avaliar os diferentes tipos de substrato quanto a sua eficiência em fornecer um bom alinhamento. Também inclui um estudo da energia de ancoramento para cada um desses substratos.

No capítulo 5 foram processadas imagens de filmes poliméricos produzidos pela técnica de automontagem LBL (layer by layer) eletrostática no IFSC/USP, através da qual os filmes multicamadas são obtidos por se alternar camadas de polímeros de cargas diferentes. 
O objetivo foi o de caracterizar estes filmes através de algoritmos que realizaram a contagem e a estimativa dos raios dos domínios contidos nas imagens.

O fenômeno do aumento da luminescência em filmes PPV, (poli-p-fenil-vinileno), é analisado no capítulo 6. Este efeito é obtido após a irradiação da amostra por um laser. Para caracterizar este efeito, o algoritmo de contagem de domínios apresentado no capítulo anterior é usado também neste trabalho. São analisadas as imagens antes e depois da irradiação. Como aplicação prática, foi criada uma grade de difração no polímero. Através de um processo de filtragem por Fourier, foi medida a estrutura periódica da grade, que veio a estar em concordância com o aparato experimental. Este trabalho também foi realizado em colaboração com o grupo de Polímeros do IFSC/USP.

O capítulo 7 traz o um estudo da curvatura espontânea de macromoléculas, conhecidas como brushes moleculares. Trata-se de copolímeros densamente enxertados, com a propriedade de ter sua conformação controlada através de alguns procedimentos experimentais. A alteração de sua conformação foi estudada através da aplicação do algoritmo de extração de curvaturas de contornos periódicos adaptado para esta situação. A importância deste trabalho reside no fato de que o controle de tais estruturas as tornam prospectivas unidades básicas em dispositivos nanoscópicos. Este trabalho foi realizado em um doutorado sanduíche no Department of Chemistry da University of North Carolina nos EUA. 


\section{Capítulo 2}

\section{Microscopia de Força Atômica}

\subsection{Introdução}

A invenção da Microscopia de Varredura por Sonda (Scanning Probe Microscope), SPM [9], proporcionou um extraordinário impulso na ciência fundamental, na tecnologia e em várias áreas do conhecimento humano. Em suas duas modalidades principais, STM (Scanning Tunneling Microscopy) [1] e AFM (Atomic Force Microscopy) [10], têm trazido notáveis contribuições à ciência, em especial à física, biologia, ciência dos materiais e microeletrônica, porque elas podem resolver detalhes da amostra, atingindo até mesmo a escala atômica $[11,12,116,14]$. A maior inspiração para esta geração de novos microscópios surgiu do trabalho de Binnig e Rohrer, que receberam em 1986 o Prêmio Nobel em Física [15] por inventarem o STM. O STM pode produzir imagens somente de superfícies de substâncias que conduzem elétrons e, como consequência, revela a organização atômica de inúmeros materiais. Algum tempo depois do lançamento do STM, Binnig, Quate e Gerber inventaram o AFM [2], que pode produzir imagens de superfícies não condutoras e condutoras. Tanto o STM como o AFM tem em comum o processo de captação de imagens. O estudo contínuo da interpretação destas imagens é fundamental pois é uma das ferramentas mais importantes em todo o processo de investigação da estrutura íntima da matéria.

Visto que o AFM pode produzir imagens de condutores e isolantes, mantendo-se as amostras no ar, no liquido ou no vácuo, esta modalidade possui uma gama maior de aplicações em relação ao STM. O AFM tem sido utilizado em diferentes áreas do conhecimento. Além 
das áreas já citadas podemos incluir a geologia e eletroquímica [16, 17].

Considerando que este trabalho concentrou-se na análise e processamento de imagens de polímeros, todas as imagens analisadas foram obtidas através do AFM. A seguir, será descrito o princípio de funcionamento do AFM e exemplos de sua aplicação em polímeros.

\subsection{O AFM}

O AFM produz imagens topográficas de superfícies condutoras e não condutoras, podendo atingir resolução nanométrica. A figura 2.1 apresenta a estrutura do sistema do AFM.

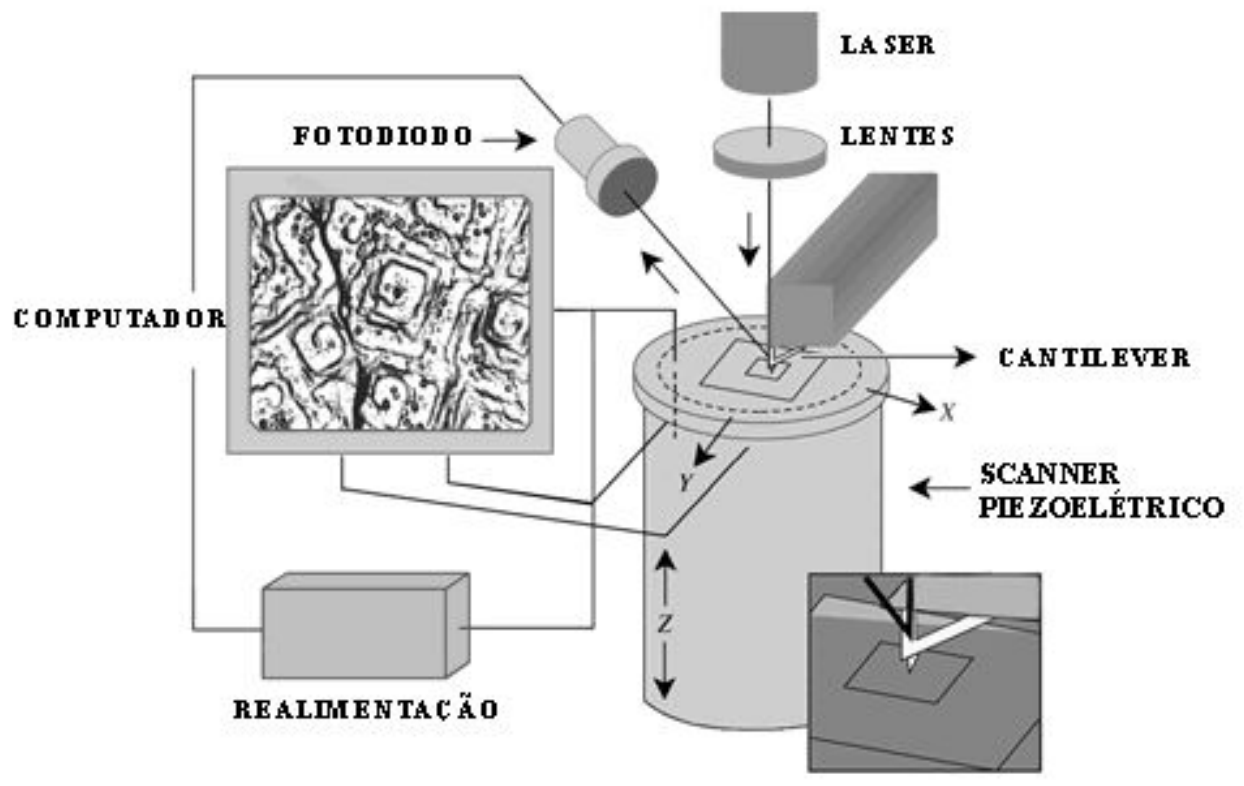

Figura 2.1: Sistema do AFM.

O cantiléver (haste) varre a superfície da amostra com uma ponta de alguns mícrons de comprimento e geralmente com menos de 20 nanômetros de diâmetro. A ponta está localizada na extremidade do cantiléver, que possui um comprimento de 100 a $200 \mu \mathrm{m}$. As forças entre a ponta e a superfície da amostra fazem com que o cantiléver se aproxime ou se afaste. Um fotodetector (fotodiodo) mede a deflexão do cantiléver à medida que a ponta varre a amostra ou a amostra é deslocada sob a ponta e com esses dados o computador gera 
um mapa da topografia da superfície.

Diversas forças contribuem para a deflexão do cantiléver. A força mais comumente associada com AFM é a força de van der Waals [18]. A dependência da força de van der Waals com a distância entre a ponta e a amostra é mostrada na figura 2.2.

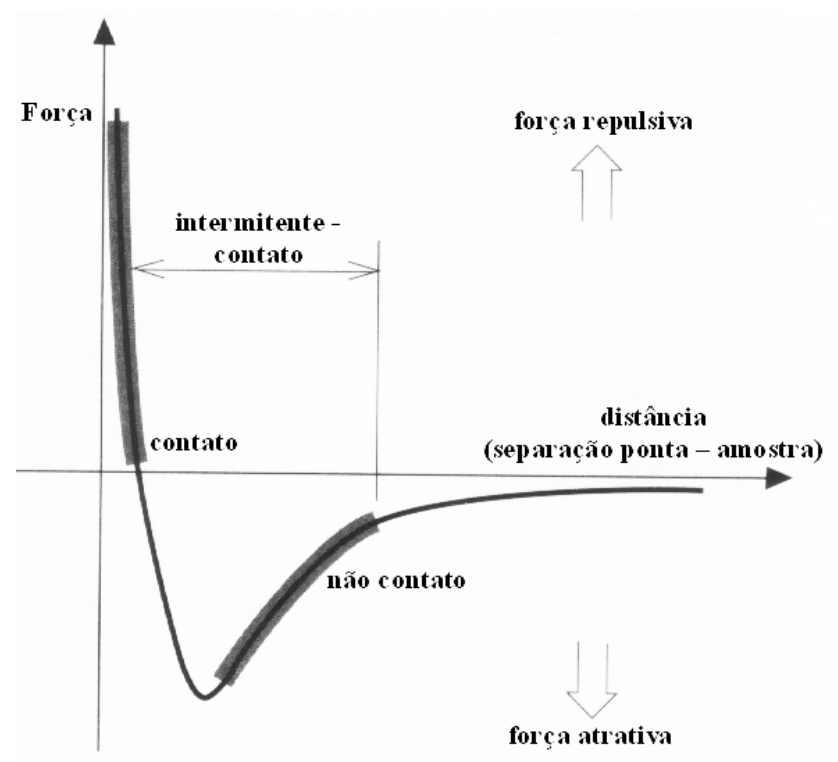

Figura 2.2: Força interatômica vs. distância [18].

Duas regiões distintas são destacadas nesta figura : 1) região de contato; e 2) região de não contato. Na região de contato, o cantiléver é mantido a poucos ângstrons da superfície da amostra e a força interatômica entre a ponta e a amostra é repulsiva. Na região de não contato, o cantiléver é mantido de dezenas a centenas de ângstrons da superfície da amostra, e a força interatômica entre a ponta e a amostra é atrativa. Estes dois modos de operação serão apresentados nas seções seguintes.

\subsection{Modos de operação}

\subsubsection{Modo Contato}

No modo contato, também conhecido como modo repulsivo, a ponta faz um leve "contato físico" com a amostra. A ponta é fixada na extremidade do cantiléver que possui uma baixa constante elástica, mais baixa que a constante elástica que mantém os átomos juntos na 
amostra. À medida que o scanner se desloca sob a ponta, a força de contato faz com que o cantiléver seja flexionado de modo a se adaptar as variações da topografia.

A deflexão do cantiléver pode ser medida por diversos métodos (deflexão óptica, controle interferométrico, piezoresistividade) [19], mas o esquema de deflexão óptica [20] é o mais comumente usado e uma de suas vantagens é a sua alta relação sinal-ruído [21]. Este esquema é mostrado na figura 2.1, onde um feixe de laser reflete no cantiléver e atinge o fotodetector. Ao passo que o cantiléver se movimenta, a posição do feixe do laser no fotodetector varia. $\mathrm{O}$ fotodetector pode medir deslocamentos de luz tão pequenos quanto 10 Å. A razão entre caminho de percurso do cantiléver ao fotodetector pelo comprimento do cantiléver produz uma amplificação mecânica. Por conta disso, o sistema pode detectar um movimento vertical do cantiléver da ordem de sub-ângstrons.

Uma vez que o AFM tenha detectado a deflexão do cantiléver, um arquivo com os dados topográficos será gerado conforme seja adotado o modo de altura constante ou força constante.

No modo de altura constante, a variação espacial da deflexão do cantiléver pode ser usada diretamente para gerar os dados topográficos porque a altura do scanner é fixa à medida que a varredura é feita. Este modo é adotado quando é necessário gerar imagens na escala atômica de superfícies planas, onde as variações na deflexão do cantiléver são pequenas e as forças aplicadas também serão menores. O modo de altura constante é também essencial para a geração de imagens em tempo real de superfícies que estão em constante alteração, onde é necessário uma alta velocidade de varredura.

No modo de força constante, os dados fornecidos pela deflexão do cantiléver podem ser usados como entrada para um circuito de realimentação que move o scanner para cima e para baixo na direção $z$ (vertical), respondendo à topografia de tal modo que a deflexão do cantiléver seja mantida constante e conseqüentemente a força total aplicada à amostra também é mantida constante. A variação da distância vertical executada pelo scanner é armazenada pelo computador para formar a imagem topográfica da superfície da amostra. O 
"loop" de realimentação pode manter a força da ponta sobre a amostra em torno de $10^{-9} \mathrm{~N}$. Neste modo, a velocidade de varredura é limitada pelo tempo de resposta do circuito de realimentação, mas a força total exercida na amostra pela ponta é bem controlada. O modo de força constante é geralmente adotado na maioria das aplicações.

\subsubsection{Modo não contato}

O modo não contato é uma das muitas técnicas em que o cantiléver vibra próximo da superfície da amostra [22]. O espaçamento entre a ponta e a amostra para o modo não contato é da ordem de alguns nanômetros. Este espaçamento é indicado na curva de força de van der Waals na figura 2.2 como o regime não contato.

$\mathrm{O}$ modo não contato mede a topografia com pouco ou nenhum contato entre a ponta e a amostra. Semelhante ao modo contato, o modo não contato pode ser usado para medir a topografia de isolantes, semicondutores e condutores elétricos. A força total entre a ponta e amostra no regime não contato é muito baixa, geralmente em torno de $10^{-12} \mathrm{~N}$, vantajoso para se estudar amostras maleáveis ou elásticas.

No modo não contato, o sistema vibra com uma freqüência em torno de 100 a $400 \mathrm{kHz}$, com uma amplitude de poucas dezenas a centenas de ângstrons. Deste modo, ele é capaz de detectar alterações na freqüência ou na amplitude da vibração à medida que a ponta se aproxima da superfície da amostra. A sensibilidade deste esquema provê uma resolução vertical da ordem de sub-ângstrons na imagem, da mesma forma que no modo contato. O sistema monitora a frequiência ressonante ou a amplitude vibracional do cantiléver e a mantém constante com a ajuda de um circuito de realimentação que move o scanner para cima e para baixo. Por se manter a freqüência ressonante ou amplitude constante, o sistema também mantém a distância média ponta-superfície constante. Como no modo contato, o movimento do scanner é usado para gerar os dados das alturas.

O modo não contato não sofre dos efeitos do atrito sobre a amostra, causados pela ponta, conforme é observado no modo contato após diversas varreduras. Por outro lado, este modo 
não tem encontrado aplicabilidade geral devido à instabilidade e resolução reduzida [23]. Esta limitação foi contornada através do modo contato intermitente ou tapping.

\subsubsection{Modo contato intermitente (tapping)}

Este modo é similar ao não contato, exceto pelo fato de que a ponta vibrante fica mais próxima da amostra de modo que ela chega a "bater" na amostra e é utilizado para contornar as limitações impostas pelo modo contato. Assim como no caso do modo não contato, o modo intermitente é utilizado para se estudar materiais moles [23, 24]. Conforme esperado, a comparação das imagens no modo contato e no modo intermitente mostra que as superfícies são menos modificadas no modo intermitente [25]. A região de operação na curva da força de van der Waals pode ser vista na figura 2.2. Como no caso não contato, a amplitude de oscilação do cantiléver é alterada em resposta ao espaçamento entre a ponta e a amostra. Uma imagem representando a topografia da superfície é obtida por se monitorar essas mudanças.

Algumas amostras são mais apropriadas para o modo intermitente ao invés dos outros modos. O modo intermitente irá prejudicar menos a amostra que o modo contato porque elimina as forças laterais entre a ponta e a amostra.

\subsection{O scanner}

Praticamente em todos os SPM, um scanner piezelétrico é utilizado para mover a ponta sobre a amostra (ou a amostra sob a ponta). O sistema eletrônico do SPM dirige o scanner numa varredura conforme mostra a figura 2.3 .

O scanner move-se ao longo da primeira linha de varredura e volta. Dá um passo na direção perpendicular para a segunda linha de varredura e assim por diante. Os dados do SPM são registrados somente em uma direção, geralmente chamada de direção de varredura rápida, para minimizar o registro de erros resultantes da histerese do scanner (veja a seção 2.4.2). A direção perpendicular em que o scanner avança linha por linha, é chamada direção de varredura lenta. 


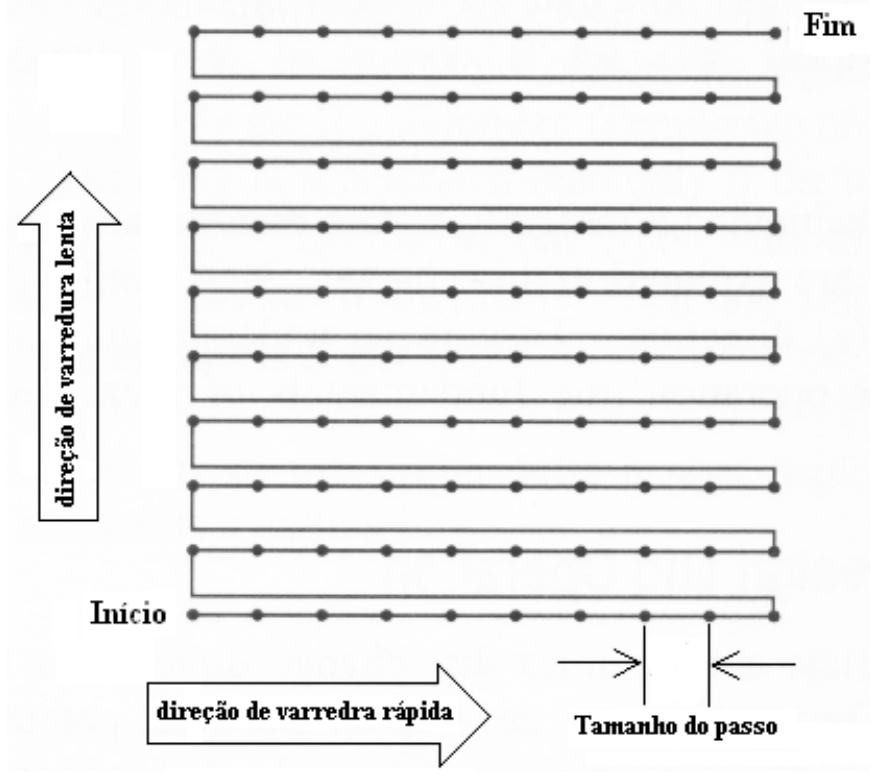

Figura 2.3: Varredura do scanner do AFM da Park Intruments. [18].

O espaçamento entre os pontos de dados é chamado de tamanho de passo. O tamanho de passo é determinado pelo tamanho da varredura e o número de pontos de dados por linha. Em uma imagem típica de SPM, a varredura varia de dezenas de ângstrons a 100 mícrons e de 64 a 512 pontos de dados por linha. (Alguns sistemas oferecem 1024 pontos por linha). O número de linhas em um conjunto de dados geralmente é igual ao número de pontos por linha. As dificuldades em se obterem medidas precisas que reflitam a topografia da amostra serão discutidas nas seções seguintes. Para se obter um entendimento dos mecanismos por detrás da operação do scanner, os fundamentos dos scanners piezelétricos serão apresentados.

\subsubsection{Design do scanner e operação}

Os materiais piezelétricos são cerâmicas que mudam de dimensão em resposta a aplicação de uma voltagem. Do mesmo modo, eles desenvolvem um potencial elétrico em resposta a pressão mecânica. Os scanners piezelétricos podem ser utilizados para o movimento nas direções $x, y$ e $z$ por se expandir em algumas direções e se contrair em outras [26]. Muitos SPMs usam variações de uma forma tubular simples, conforme figura 2.4. Nesta figura o scanner é um tubo oco. 


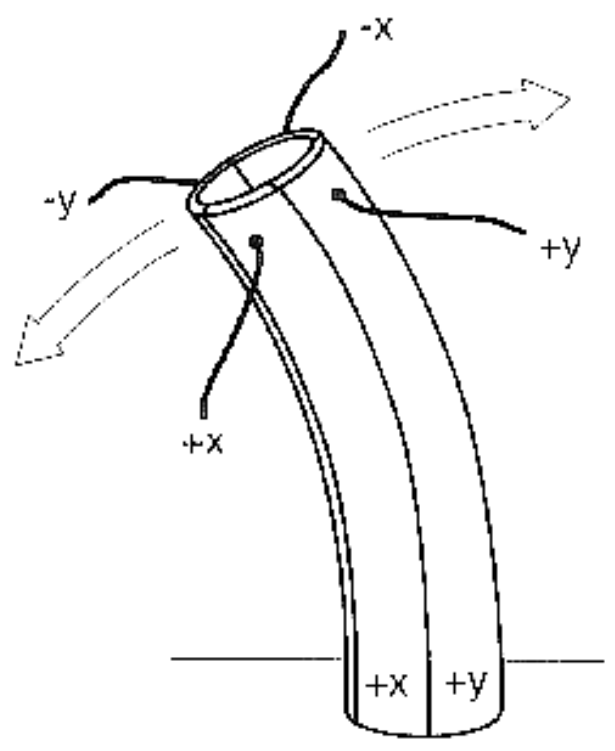

Figura 2.4: Tubo do scanner [18].

Eletrodos são conectados do lado de fora do tubo, nos pontos $+x,-x,+y \mathrm{e}-y$. Um eletrodo também é conectado no centro do tubo para provocar o movimento na direção $z$. Quando tensões alternadas são aplicadas nos eletrodos $+x \mathrm{e}-x$, por exemplo, a deformação induzida no tubo faz com que ele se flexione para frente e para trás na direção $x$. As voltagens aplicadas ao eletrodo $z$ fazem com que o scanner se estenda ou se contraia verticalmente. A geração de imagens em escala atômica requer um scanner com um tubo mais curto com um coeficiente piezomecânico na faixa de $15-20 \AA / \mathrm{V}$, o que permite o movimento da ponta com precisão de 0,01 Å. Para se escanear áreas maiores que $100 \mu m$ x $100 \mu m$, é necessário o uso de um scanner com um tubo mais longo com um coeficiente na faixa de 200-300 $\mathrm{nm} / \mathrm{V}$.

Os scanners piezelétricos são elementos críticos em SPMs, importantes pela sua resolução da ordem de subângstrons, seu tamanho compacto e sua resposta de alta velocidade. No entanto, junto com essas propriedades essenciais, há alguns desafios.

\subsubsection{Não linearidades do scanner}

Como uma primeira aproximação, a deformação em um scanner piezelétrico varia linearmente com a voltagem aplicada. (A deformação é a variação no comprimento dividida pelo comprimento original, $\Delta l / l)$. A equação 2.1 descreve a relação ideal entre a deformação e 
um campo elétrico aplicado :

$$
S=d E
$$

onde $S$ é a deformação em $\AA / \mathrm{m}, E$ é o campo elétrico em $\mathrm{V} / \mathrm{m}$ e $d$ é o coeficiente de deformação em $\AA$ AVV. O coeficiente de deformação é característico de um dado material piezelétrico.

Na prática, o comportamento dos scanners piezelétricos não é simples, pois a relação entre a deformação e o campo elétrico diverge do comportamento linear ideal. Estas divergências serão descritas nas seções seguintes.

\section{Não linearidade intrínseca}

Suponha que a voltagem aplicada comece do zero e gradualmente aumente para algum valor finito. Se a extensão do material piezelétrico é plotado como função da voltagem aplicada, o gráfico não será uma linha reta, mas uma curva em forma de $S$, conforme a figura 2.5. A linha pontilhada no gráfico é um ajuste linear dos dados.

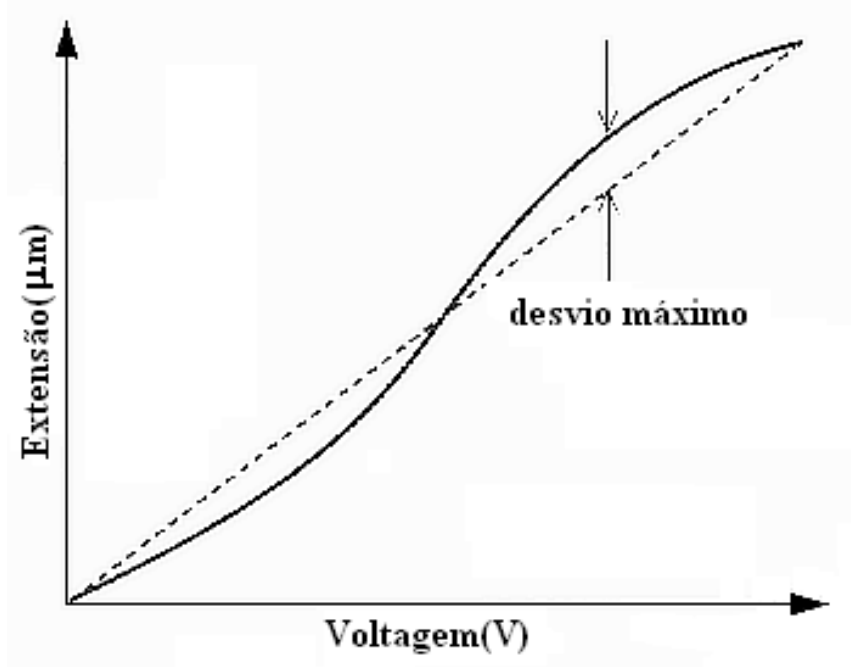

Figura 2.5: Não linearidade intrínseca do scanner [18].

No plano da superfície da amostra, o efeito da não linearidade intrínseca é a distorção da medida da grade da figura 2.3. Visto que o scanner não se move linearmente com a 
voltagem aplicada, os pontos da medida não serão igualmente espaçados. Como resultado, uma imagem de SPM de uma superfície com estruturas periódicas mostrará espaçamentos não uniformes e estruturas lineares curvas [27]. Superfícies menos regulares talvez não mostrem distorções perceptíveis embora a distorção esteja presente.

Perpendicular ao plano da superfície da amostra, na direção $z$, a não linearidade intrínseca provoca erros nas medidas de altura. A altura é calibrada por se escanear uma amostra de altura conhecida, comparando-se com as medidas obtidas pelo SPM.

Outras técnicas de correção através de software serão apresentadas na seção 3.2.1.

\section{Histerese}

Além da não linearidade do scanner, as cerâmicas piezelétricas demonstram histerese em seu funcionamento. Suponhamos que a voltagem comece a ser aplicada a partir de zero, aumentando gradualmente a voltagem até um valor finito e depois diminuindo até zero. Se fizermos um gráfico do comprimento da cerâmica como função da voltagem aplicada, a curva descendente não será a mesma que a ascendente, seguindo um outro caminho, conforme mostrado na figura 2.6 .

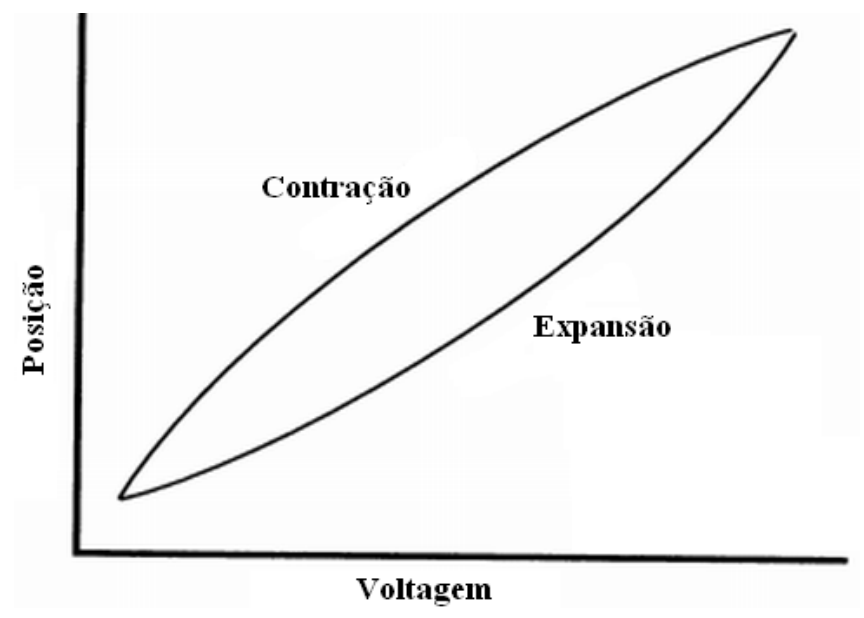

Figura 2.6: Histerese do scanner [28].

Isto significa que o scanner se move menos por volt aplicado no começo da expansão, do que no final. O mesmo é verdadeiro quando o scanner se contrai, ele se move menos por volt aplicado no começo de sua contração do que próximo ao fim. 
A histerese de um scanner piezelétrico é a razão da diferença máxima entre as duas curvas e a extensão máxima que a voltagem pode criar no scanner: $\Delta Y / Y_{\max }$. O efeito da histerese pode chegar a $20 \%$ em materiais piezelétricos [18].

Conforme mencionado antes, os dados de SPM são geralmente gerados em um sentido para minimizar erros de captação, causados pela histerese do scanner. A figura 2.6 mostra que os dados gerados no retorno são ligeiramente deslocados, distorcendo as medidas na grade da figura 2.3.

Tanto a não-linearidade como a histerese provocam distorções nas imagens de SPM se não forem corretamente corrigidas. Exemplos desses efeitos em imagens de AFM são mostrados na figura 2.7 em uma grade de calibração. A profundidade de cada quadrado é de $180 \mathrm{~nm}$ e $10 \mu \mathrm{m}$ de lado.

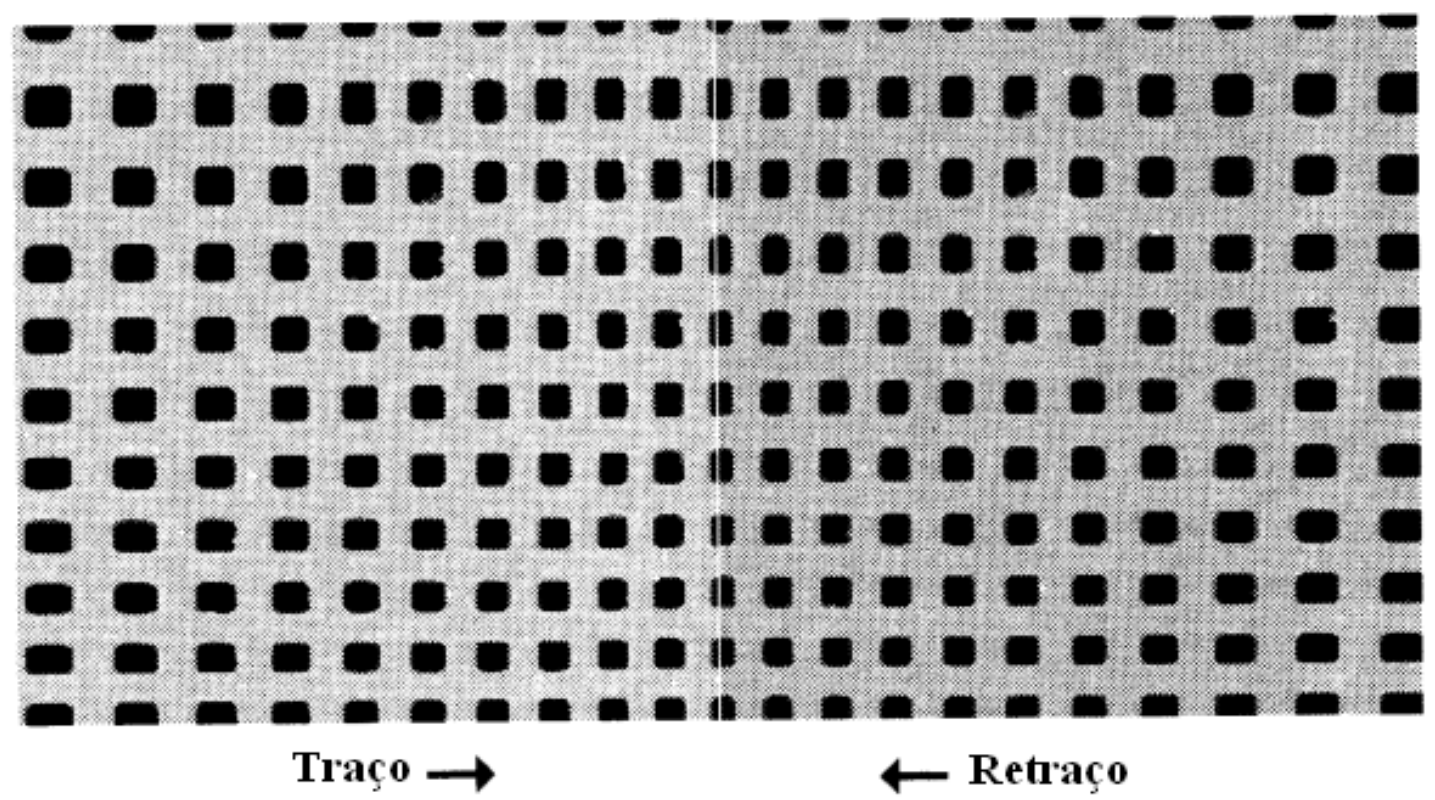

Figura 2.7: Efeito da histerese em imagens de $100 \mu m$ x $100 \mu m$, nas direções de traço e retraço [28].

A histerese na direção perpendicular ao plano da amostra provoca erros nas medidas de altura, conforme a figura 2.8 .

De acordo com a curva da figura 2.6, vemos que se a ponta encontra um degrau na superfície da amostra, uma certa voltagem é necessária para que o scanner se contraia. Quando a ponta passa por esse degrau o scanner terá que se expandir, e essa expansão exigirá uma 


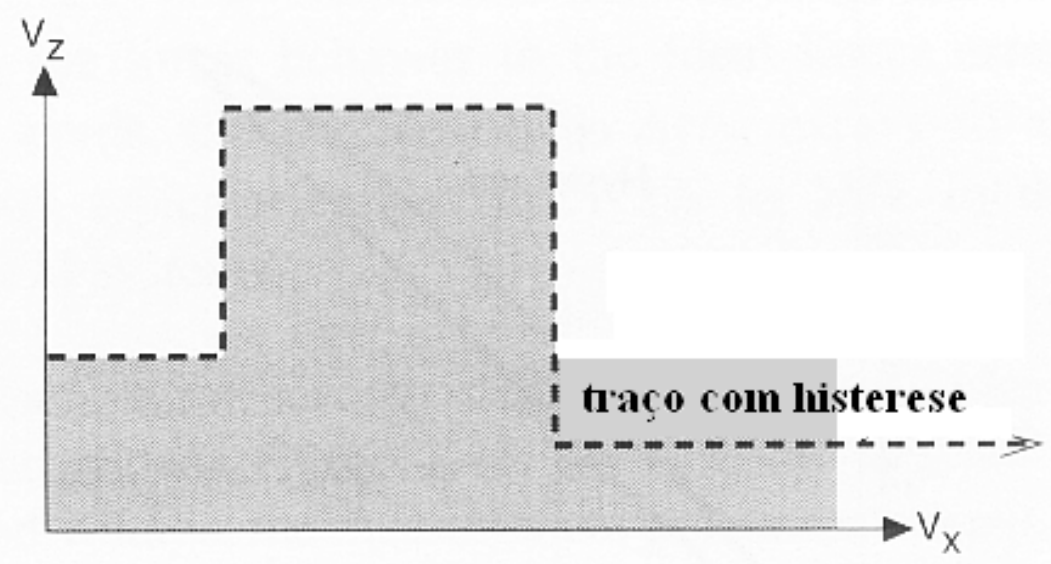

Figura 2.8: Histerese na altura [18].

voltagem maior do que a que foi necessária na contração. A figura 2.8 mostra o efeito das diferenças de voltagem aplicadas ao scanner nas medidas de altura.

\subsubsection{Arrasto (creep)}

Este é um efeito pelo qual uma cerâmica continua a deformar-se depois de uma rápida variação de voltagem, como se mostra na figura 2.9 , e é devido a um reordenamento de domínios. Este efeito também é mais pronunciado em cerâmicas macias e maciças. Há também um excesso (overshoot) no deslocamento depois da aplicação da voltagem, seguido de uma "ressonância" (ringing) da cerâmica.

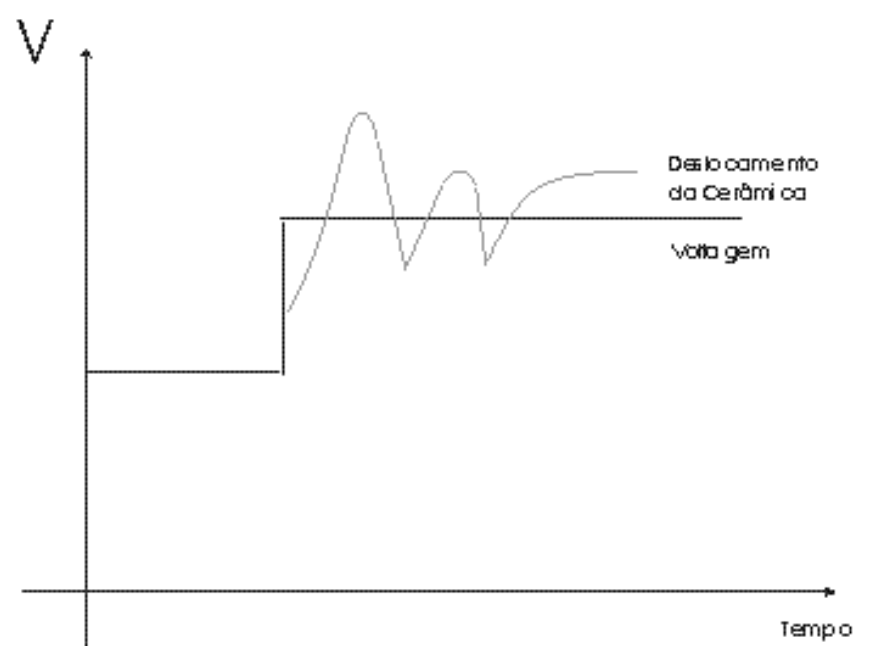

Figura 2.9: Deformação das cerâmicas com o tempo, em função da voltagem aplicada.

Isto se traduz nas imagens da seguinte forma. Quando se aplica no material piezelétrico 
uma voltagem, ele não muda de dimensões imediatamente. A mudança ocorre em dois passos: o primeiro acontece em menos de milissegundos e o segundo em muito mais tempo. Na figura 2.10, esse segundo passo é o indicado por $\Delta x_{c}$ e define o creep propriamente dito.

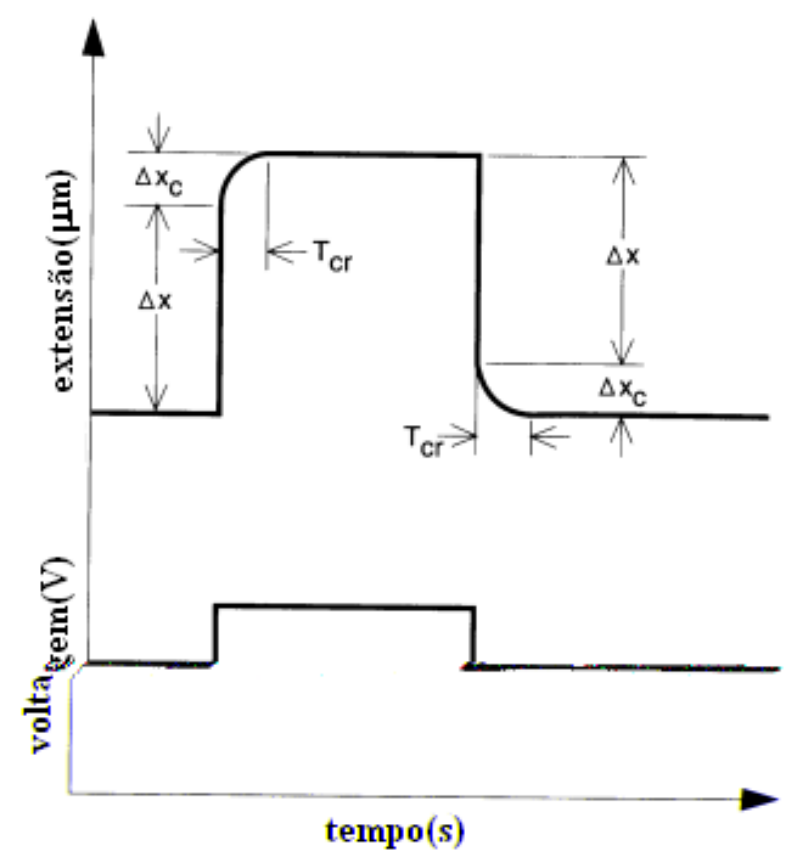

Figura 2.10: Creep de um scanner [18].

Quantitativamente o creep é a razão entre a segunda variação dimensional e a primeira, isto é $\Delta x_{c} / \Delta x$. O creep é expresso como uma percentagem e é geralmente dado em função do intervalo de tempo característico $T_{c r}$ durante o qual ocorre. Valores típicos são de $1 \mathrm{a}$ $20 \%$ em tempos que variam de 10 a 100 segundos.

O tempo gasto para fazer a varredura coloca o movimento lateral do scanner na parte curvada do gráfico da figura 2.10. Como resultado disto, duas varreduras feitas a diferentes velocidades irão mostrar diferentes medidas se houver creep. Outro efeito do creep no plano $(x, y)$ é que ele pode interferir na localização de uma parte da amostra quando se quer fazer um zoom. Querendo por exemplo caracterizar um defeito sobre uma amostra, em geral se começa por fazer uma ampla varredura para localizar esse defeito. A seguir, se faz uma varredura de maior resolução, com o defeito centrado nela. Para fazer este zoom, o microscópio aplica uma voltagem visando mover o scanner até a posição desejada. Devido a 
essa voltagem, se houver creep, pode-se perder a localização do defeito (isto se chama $d r i f t$ ).

Na direção $z$, os efeitos do creep podem ser vistos na figura 2.11 .

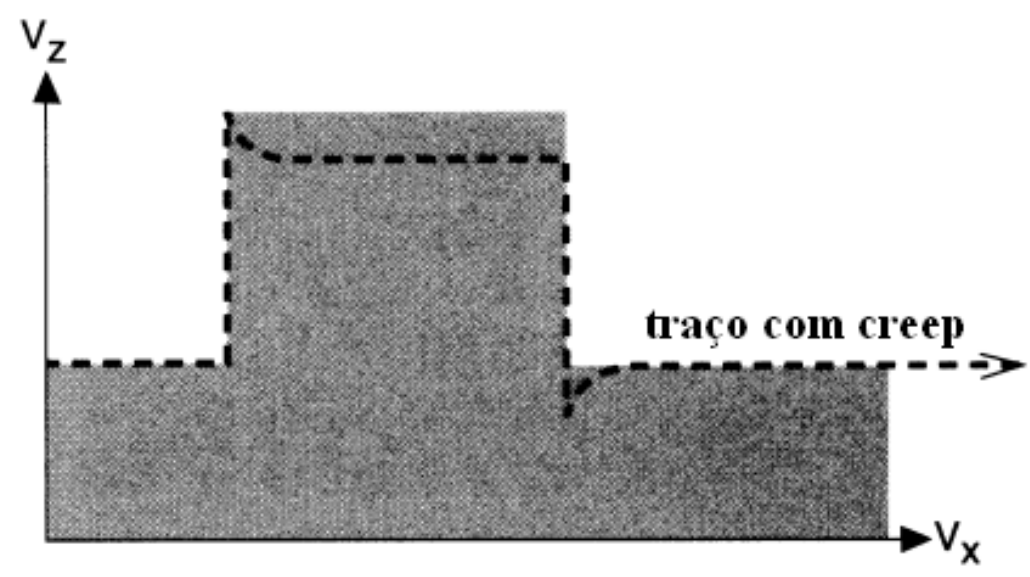

Figura 2.11: Creep na direção $z$ [18].

Quando a ponta passa sobre o degrau, de baixo para cima, o scanner sofre uma contração com a voltagem aplicada, que corresponde à altura total do degrau. Entretanto, nos próximos segundos, o scanner continua a se contrair lentamente à medida que acontece o creep. Para manter a ponta em contato com a amostra o sistema deve aplicar uma voltagem na direção contrária para compensar o creep. Quando a ponta percorre o degrau de cima para baixo, ocorre a mesma coisa. O scanner se dilata para se acomodar ao degrau, e depois continua a se "arrastar" (creep). Novamente o sistema deverá aplicar uma voltagem na direção oposta, para manter o contato entre a ponta e a amostra.

O efeito do creep sobre o perfil de um degrau é apenas um exemplo. Este mesmo efeito em uma imagem pode ser observado na figura 2.12. Trata-se de uma grade de calibração do sistema do AFM.

A ponta escaneou a superfície de cima para baixo e um degrau de $10 \mu m$ na direção $X$ aconteceu no começo da varredura. Esta distorção foi causada pelo creep, devido ao degrau da grade. A distorção ocorreu em apenas uma linha. Para degraus maiores $(>50 \mu m)$, pode levar mais de uma linha para o creep ser eliminado [28]. 


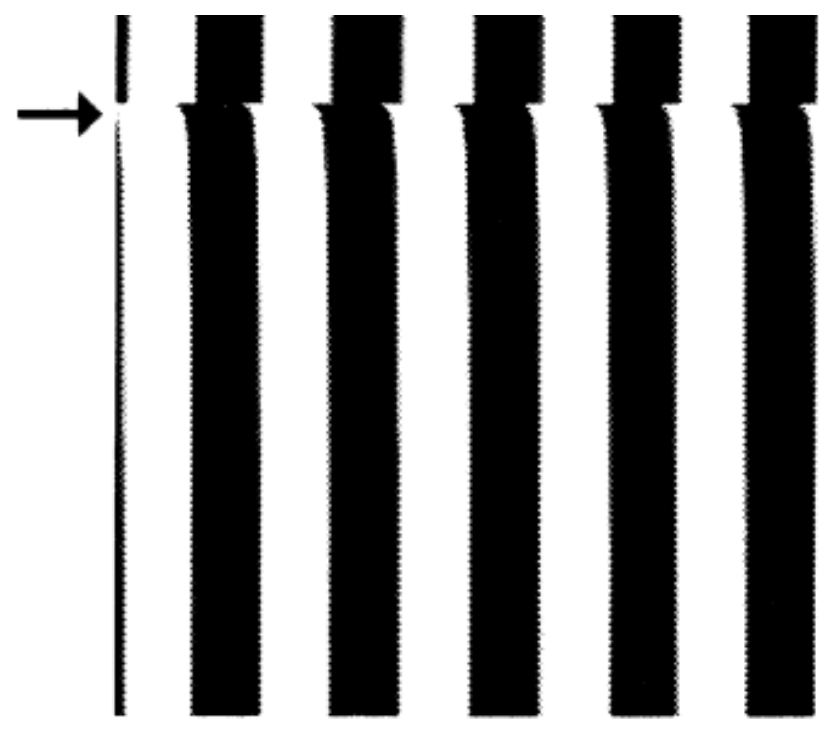

Figura 2.12: Creep na direção $z$ [28].

Para uma amostra típica com um relevo escarpado que representam defeitos, grãos ou outras particularidades da amostra, o creep pode fazer com que um detalhe contido em uma imagem de SPM pareça ter de um lado uma crista e do outro lado uma sombra. Se houver sombras onde a ponta desceu em uma escarpa inclinada e cristas onde a ponta subiu na mesma escarpa ou em outra, o creep pode ser o responsável. Revertendo o sentido da varredura rápida e fazendo-se outra imagem da mesma região, pode ajudar a separar os artefatos criados pelo creep das verdadeiras cristas e vales [18] (veja a seção 3.2.1).

\subsubsection{Acoplamento cruzado (bow)}

Este termo, mais conhecido por cross coupling ou bow, refere-se à tendência que existe nos movimentos em $x$ e $y$ de terem uma componente espúria do movimento em $z$, como se mostra na figura 2.13 .

Este movimento é bastante complexo e provém de diferentes fontes. Por exemplo, da não uniformidade do campo elétrico ao longo do scanner. O efeito de interferência dos movimentos em diferentes direções não é constante e tem uma expressão tensorial. O maior efeito é geométrico e se produz devido à maneira em que o scanner é construído, em forma tripóide ou tubular. 


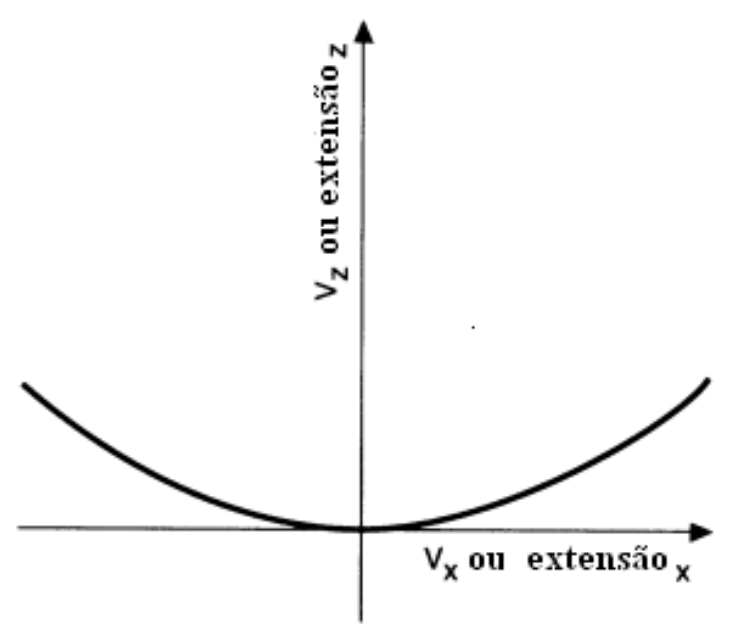

Figura 2.13: Movimento do scanner com acoplamento cruzado [18].

O movimento em $x$ e $y$ do tubo é produzido quando um dos seus lados se encolhe e o outro se expande. Como resultado disto, o scanner varre em arco e não num plano. A voltagem aplicada para mover um tubo ao longo dos eixos $x$ e $y$, isto é, paralelo à superfície da amostra, deve fazer que o scanner se estique ou se contraia ao longo do eixo z, isto é, perpendicularmente à amostra, pois é necessário manter a ponta em contato com a amostra. À medida que a varredura aumenta (o que exigirá um scanner maior), o efeito do acoplamento cruzado tende a aumentar também com o quadrado do tamanho da varredura [28]. O acoplamento cruzado num SPM pode resultar em que uma superfície seja vista em forma de bacia, em vez de plana, como mostra a figura 2.14, para o caso de um degrau.

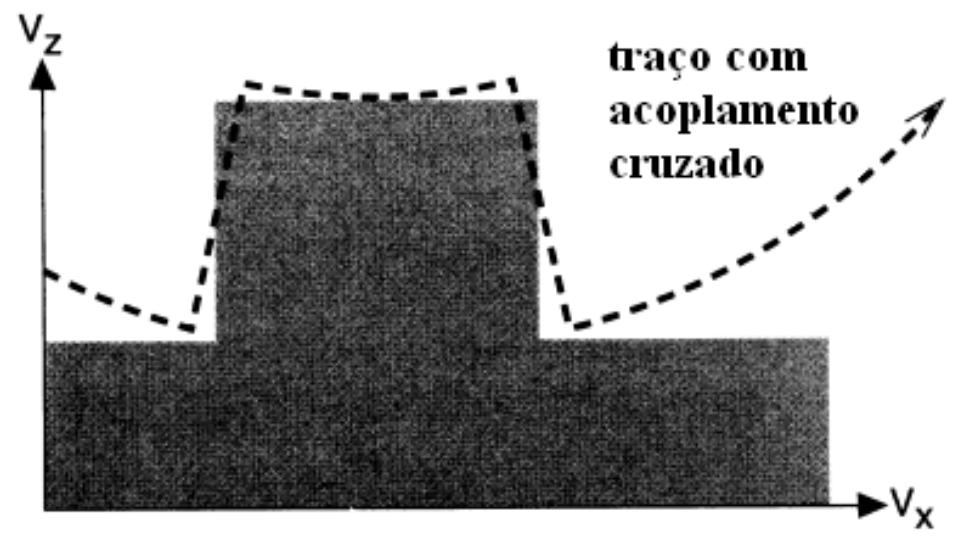

Figura 2.14: Efeitos do acoplamento cruzado sobre um degrau [18]. 
Para interpretar esta figura, é necessário lembrar que uma imagem de SPM é adquirida a partir da voltagem necessária para compensar a curvatura gerada pelo arco do scanner. A forma de bacia pode nem sempre ser muito evidente pois o background curvado pode ser retirado processando a imagem por software. A melhor forma de determinar se o scanner tem acoplamento cruzado é usar uma amostra com um raio de curvatura conhecido (por exemplo uma lente).

A imagem de um degrau, com todas estas deformações, poderia parecer com a mostrada na figura 2.15 .

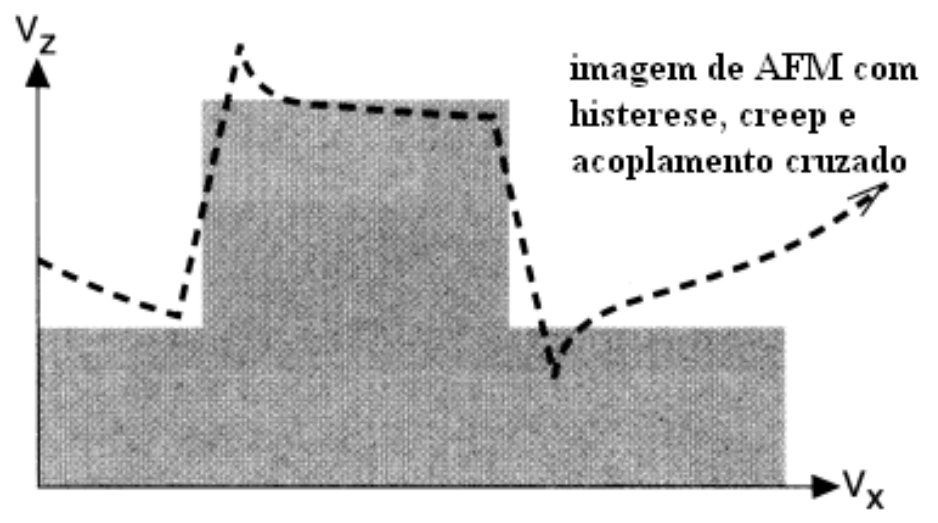

Figura 2.15: Efeitos combinados de histerese, creep e acoplamento cruzado em um degrau [18].

Outras distorções existentes no sistema piezelétrico são o envelhecimento [18], rugosidade, inclinação da amostra (tilt) $[29,30]$. Em geral, o comportamento não linear dos scanners piezelétricos descrito até aqui tem sido corrigido através do software que acompanha o sistema do SPM ou outros softwares com algoritmos desenvolvidos com esse objetivo (veja a seção 3.3). Alguns sistemas no mercado usam soluções através de hardware que eliminam a maioria das não linearidades ao invés de apenas corrigi-las. As soluções por hardware são divididas em óptica, capacitiva e por medida de tensão [27, 31, 18]. Os melhores sistemas combinam hardware e software para as correções. 


\subsection{Sondas}

As sondas que são normalmente usadas para medidas em AFM são cantiléveres com pontas integradas de $\mathrm{Si}_{3} \mathrm{~N}_{4}$ ou silício [32]. Os cantiléveres são preparados com diferentes comprimentos, espessuras e formas. Sua constante elástica varia de 0,01 a $50 \mathrm{~N} / \mathrm{m}$. A forma da ponta e a constante elástica $k$ do cantiléver são parâmetros importantes nas medidas de AFM. Dois aspectos críticos envolvendo a ponta e a qualidade das imagens é a resolução obtida e a dilatação morfológica com a ponta, que serão descritas a seguir.

A resolução lateral de uma imagem de AFM é determinada por dois fatores: o tamanho do passo da imagem e o raio mínimo da ponta. Por exemplo, para uma imagem de 512 por 512 pontos, uma varredura de $1 \mu m$ por $1 \mu m$ teria um tamanho de passo - e resolução lateral - em torno de $20 \AA$.

As pontas mais finas disponíveis comercialmente, podem ter um raio de até 50 Å. Devido a área de interação entre a ponta e a amostra ser uma fração do raio da ponta, estas pontas fornecem tipicamente uma resolução lateral de 10 a $20 \AA$.

A maioria dos artefatos da imagem em SPM surge de um fenômeno conhecido como convolução com a ponta. Este termo na verdade não é apropriado porque sugere um procedimento reversível envolvendo a transformada de Fourier. O termo mais apropriado seria “dilatação morfológica” ou simplesmente dilatação, cuja operação inversa “erosão" é tambem chamada erroneamente de "deconvolução". Sendo assim, cada ponto de dado em uma imagem representa uma dilatação da forma da superfície pela forma da ponta. Quanto mais fina for a ponta em relação ao detalhe, melhor será o perfil obtido pelo SPM e menor será a dilatação. O resultado desta dilatação é que os picos terão um volume maior que o real e os vales terão um volume menor. A figura 2.16 demonstra a origem da dilatação com a ponta e o efeito nos picos e vales, através de perfis na amostra e imagem resultante.

Muitas amostras apresentam detalhes com lados escarpados, e por este motivo, apresentarão dilatação com a ponta. A profundidade de um vale, só será reproduzida de forma 


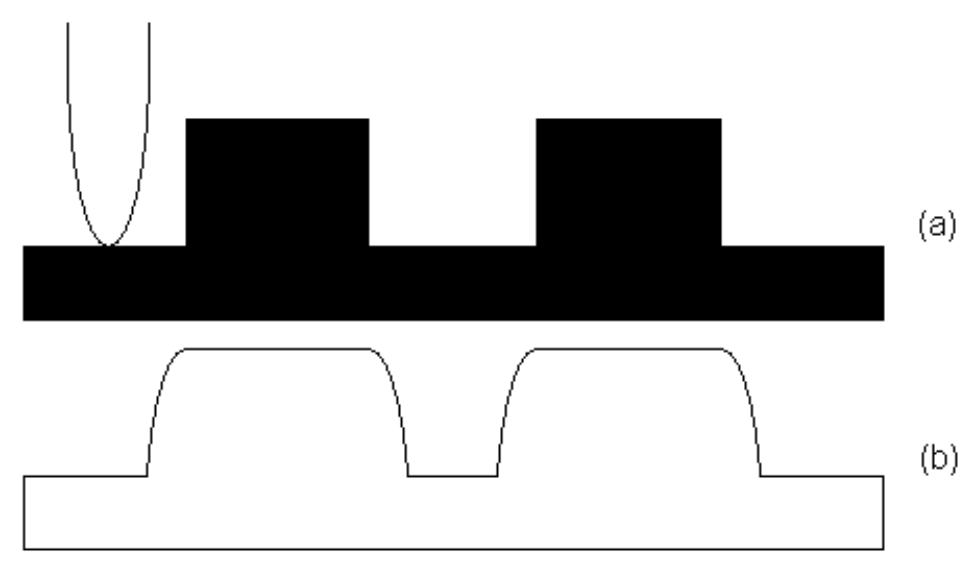

Figura 2.16: Esquema do efeito da ponta do AFM sobre a imagem da amostra: (a) Superfície da amostra, (b) perfil da imagem da superfície, dilatada pela ponta.

precisa se a ponta tocar na base do vale. Se a ponta for mais larga que o vale, sua profundidade não será reproduzida com exatidão. Este problema não ocorre com a altura dos picos mais altos, pois em geral, a ponta faz contato com as partes mais altas da superfície. Isto significa que nas distorções provocadas pela interação da ponta com a amostra, a resolução vertical é mais precisa que a resolução lateral.

Para minimizar os efeitos da ponta, o seu tamanho característico deve ser similar ou menor que o objeto a ser estudado. Para alcançar resolução atômica, a ponta tem de terminar em um pequeno conjunto de átomos [33]. A fim de se escanear uma profundidade da ordem de mícrons, o diâmetro da ponta não pode exceder essa ordem. Além disso, uma grande variedade de formas de ponta podem ser necessárias para medir amostras com reentrâncias ou escarpas em sua topografia [34]. Para obter medidas confiáveis, é necessário usar materiais padrões de referência, que permitam uma calibração precisa [31]. Além do cuidado com a escolha da ponta, é possível obter um melhoramento da imagem através de softwares, que fazem a erosão da imagem da superfície com a forma da ponta. Isto será discutido na seção 3.3.1. 


\subsection{Aplicações em polímeros}

Importantes propriedades de materiais poliméricos, tais como adesão, atrito, molhamento, crescimento, penetrabilidade, compatibilidade biológica, são fortemente influenciadas pelas suas superfícies. Em geral, a estrutura e a morfologia da camada mais externa é diferente daquelas no interior do polímero. Sendo assim, uma análise compreensiva da superfície é necessária para se correlacionar as estruturas da superfície com propriedades químicas e físicas. Por outro lado, a caracterização de superfícies em geral é uma tarefa difícil devido ao limitado número de técnicas apropriadas para tais investigações. Neste contexto, a microscopia de varredura por sonda assumiu grande importância por apresentar uma família de técnicas avançadas para análise de superfícies [19]. Embora o STM tenha sido inventado primeiro, o atual progresso na microscopia de varredura por sonda em polímeros tem sido através do AFM. A característica universal das forças repulsivas entre a ponta e a amostra, que são empregadas para análise de superfícies em AFM, possibilita o exame de uma variedade muito grande de materiais. Inicialmente, os estudos em AFM eram direcionados para a visualização da morfologia dos polímeros, nanoestrutura e ordem molecular. Essas investigações tem sido realizadas em um grande número de amostras poliméricas [35]. Atualmente, o espectro de aplicações do AFM em polímeros se alargou substancialmente devido à descoberta de novas possibilidades em AFM. Em adição a perfis de alta resolução da morfologia da superfície e nanoestrutura, o AFM permite a determinação das propriedades locais dos materiais e mapeamento da composição da superfície em amostras heterogêneas. Adicionalmente, além da camada mais externa é possível examinar a estrutura próxima a superfície. Apesar de ter sido introduzido após o STM, para o estudo da topografia de superfícies não condutoras, o AFM transformou-se em uma técnica multifuncional apropriada para a caracterização da topografia, adesão, mecânica e outras propriedades na escala de centenas de mícrons a nanômetros. Materiais poliméricos, que desempenham um papel importante na tecnologia moderna tem sido examinados por AFM [36]. Um crescente interesse tecnológico nas propriedades dos polímeros em escala nanométrica enfatiza a importância da aplicação do AFM em polímeros. 
Será apresentado a seguir, um exemplo de como a técnica de AFM tem sido usada no estudo da morfologia de superfícies poliméricas.

\subsubsection{Imagens de AFM de polímeros orientados}

A morfologia e a estrutura molecular de polímeros orientados são de grande interesse devido a uma grande variedade de aplicações tecnológicas [115]. Uma dessas aplicações que envolve o esticamento uniaxial do polímero e que resulta em uma estrutura de cadeia estendida é utilizada na preparação de materiais orientados. A deformação desses polímeros tem sido examinada por diferentes métodos (difração, espectroscopia, microscopia eletrônica) e os principais processos moleculares que acompanham essa deformação são conhecidos. No entanto, mesmo a teoria amplamente aceita de Peterlin [38] não pode explicar todos os experimentos, devido ao pouco conhecimento dos detalhes estruturais na escala de $1-100 \mathrm{~nm}$. A caracterização destes detalhes em escala nanométrica pode ser melhorada significativamente através do AFM.

A figura 2.17 [19] mostra imagens de cadeias de polímeros individuais para a superfície de uma amostra de polietileno (PE) cold-extruded, obtidas através de AFM.

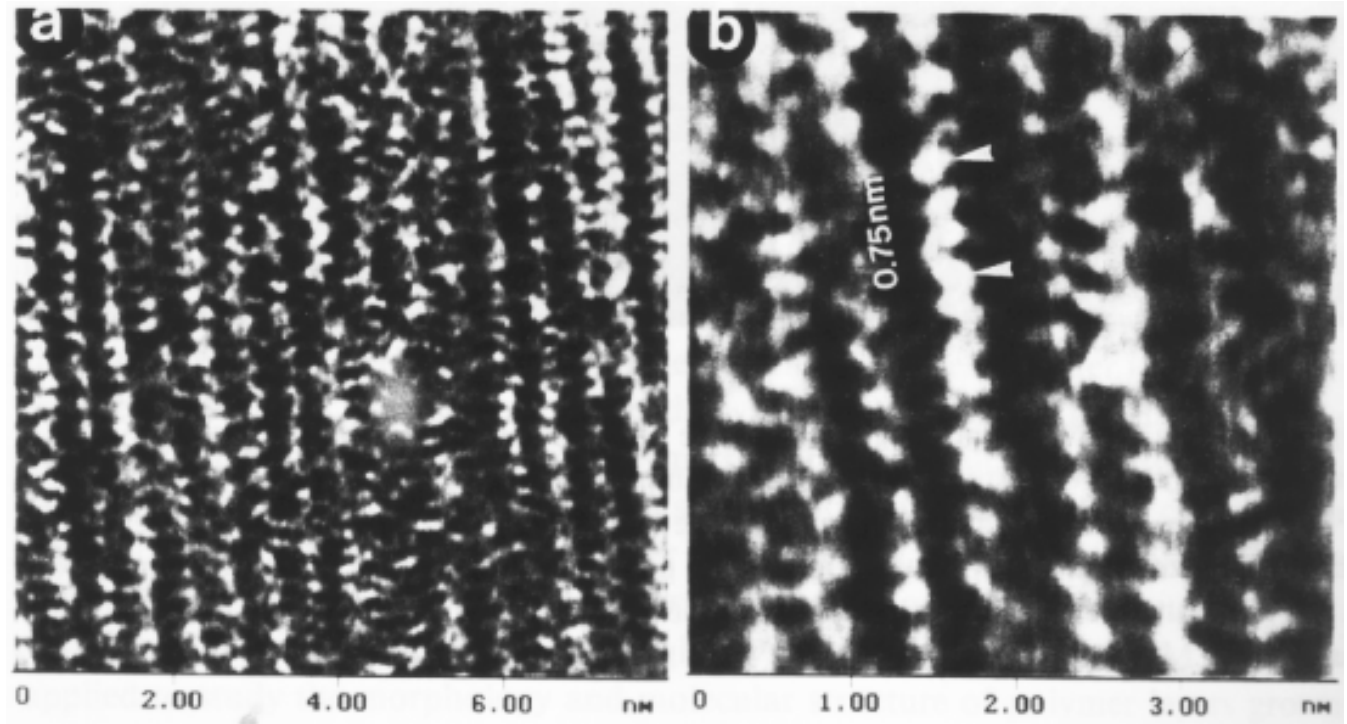

Figura 2.17: (a) Imagem de AFM mostrando o empacotamento de cadeias sobre a superfície de PE cold-extruded. (b) Zoom da figura(a). A periodicidade de $0.25 \mathrm{~nm}$ ao longo da imagem corresponde a conformação trans das cadeias [19]. 
Nestas imagens, as cadeias de PE são vistas como linhas verticais que são separadas por $0.5 \mathrm{~nm}$, com calombos de período $0.25 \mathrm{~nm}$. Estes parâmetros se correlacionam com aqueles esperados para um empacotamento cristalino onde todas as moléculas trans de PE foram esticadas. Imagens similares foram obtidas de filmes PE esticados de alto peso molecular (UHMW) [39].

A imagem de AFM de uma camada de politetrafluoroetileno (PTFE) depositada em substrato observada na figura 2.18, também mostra um empacotamento de cadeias de periodicidade $0,56 \mathrm{~nm}$, concordando com os dados estruturais obtidos por Raios-X [19].
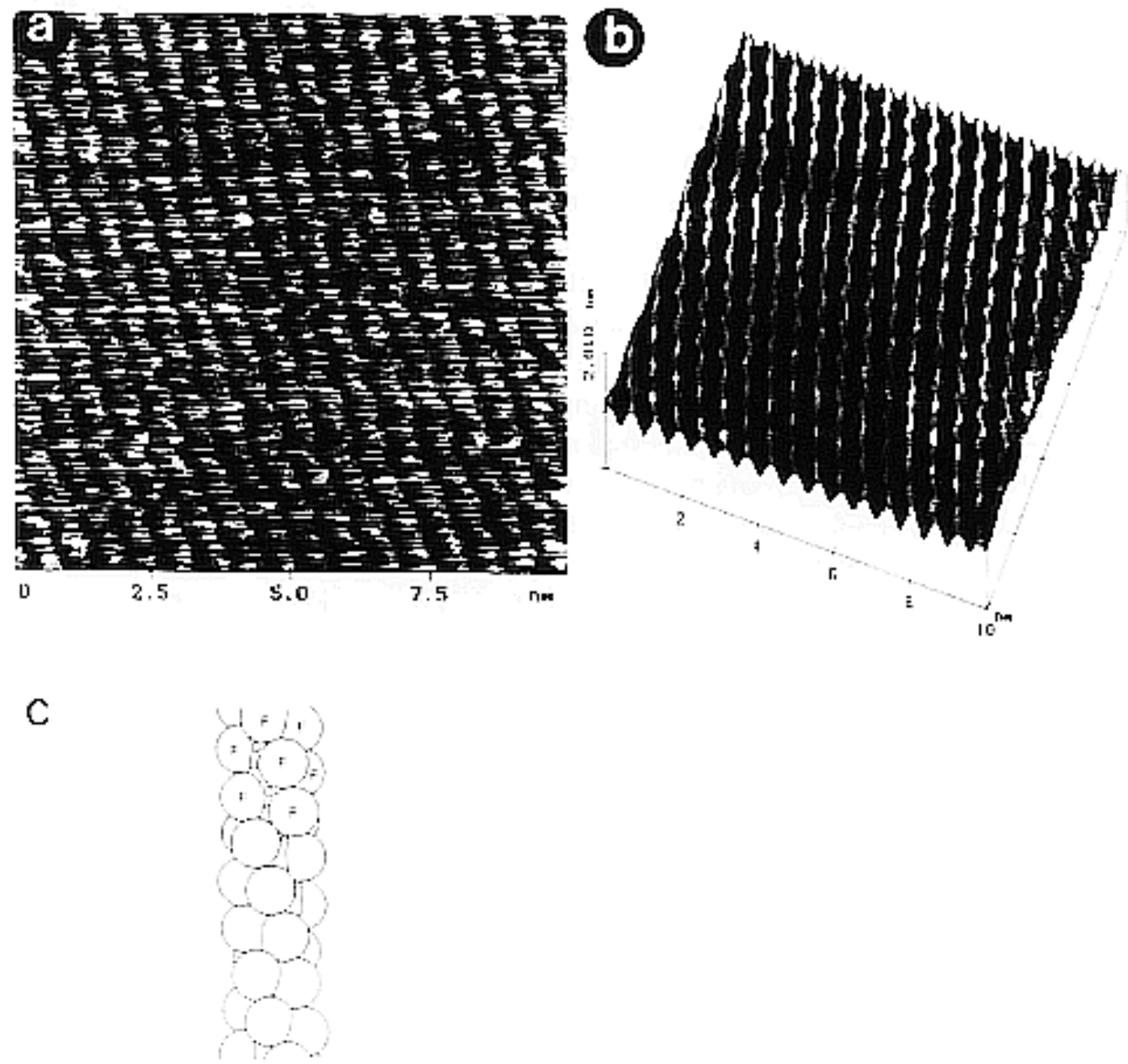

Figura 2.18: (a) Imagem de AFM de uma camada de PTFE depositada por rubbing em um substrato de vidro. (b) Vista da superfície da figura (a) após filtragem. (c) Esquema mostrando a cadeia helicoidal $13_{6}$ de PTFE [19].

As distâncias entre os calombos ao longo das linhas que representam cadeias PTFE $(0,83 \mathrm{~nm})$ são iguais à metade do período $(1,69 \mathrm{~nm})$ ao longo da cadeia helicoidal $13_{6}$, fi- 
gura 2.18. Deste modo, através do AFM é possível estudar a conformação de moléculas poliméricas. Também, em estudos de amostras esticadas de polipropileno (PP), foi possível distinguir cadeias com orientações para a esquerda e para a direita [40]. 


\section{Capítulo 3}

\section{Processamento e Análise de Imagens em SPM}

\subsection{O uso de softwares de análise e processamento de imagens}

Nos primeiros anos de uso do SPM, as análises das imagens eram restritas apenas a inspeção visual, sujeitas a algumas etapas de processamento disponíveis no software do fabricante do equipamento. No entanto, este tipo de análise mostrou-se bastante subjetivo, qualitativo e impreciso, não permitindo uma caracterização mais objetiva, quantitativa e automatizada da amostra. Por este motivo, diversos pesquisadores viram a necessidade de desenvolver algoritmos e softwares específicos para que determinadas medidas pudessem ser feitas nas imagens. Deste modo, propriedades importantes concernentes à geometria e morfologia da amostra puderam ser identificadas e classificadas. A partir daí, surgiu na literatura uma série de trabalhos de caráter interdisciplinar, em que algum algoritmo da área de processamento ou análise de imagens passou a ser utilizado como ferramenta auxiliar na caracterização de imagens de SPM e outros foram desenvolvidos com essa finalidade.

\subsection{Algoritmos de análise e processamento de imagens}

A área de imagens se divide em diversas subáreas, dentre as quais destacam-se duas nesta tese: análise de imagens e processamento de imagens. O processamento de imagens envolve 
a transformação de uma imagem em outra, a fim de se reduzir o ruído ou distorções incorporadas no processo de captação da imagem. A análise de imagens envolve a obtenção de medidas das propriedades dos elementos contidos na imagem. Nas seções seguintes serão apresentados estudos que exemplificam estas duas subáreas.

\subsubsection{Processamento de Imagens}

No SPM, o processo de captação das imagens vem acompanhado de distorções conforme foi abordado nas seções 2.4 e 2.5 , provocadas tanto pela não linearidade do scanner como pela interação entre a ponta e a amostra. Os softwares desenvolvidos pelos fabricantes do SPM usualmente possuem algum algoritmo para calibração e correção destas distorções [28]. No entanto, tais algoritmos são limitados e dependem sempre de amostras padrão para a calibração. Nos últimos anos, vários algoritmos foram desenvolvidos para minimizar estas distorções e que nem sempre dependem de amostras padrão [31, 41]. Para um préprocessamento, o filtro da mediana[3, 6] tem se mostrado o mais indicado [43, 114], a fim de se eliminar riscos e ruídos provocados pela ponta do cantilever. Basicamente, este filtro não-linear envolve o ordenamento dos 8-vizinhos de cada pixel na imagem e o valor mediano é atribuído na imagem filtrada.

O problema da não linearidade do scanner tem sido contornado medindo-se a sua posição através de um detector, e então usar esta informação para corrigir as não-linearidades. R. C. Barret e C. F. Quate [27], desenvolveram um sensor optico para medir os movimentos do scanner. Com esta informação, foi desenvolvido um algoritmo para a correção da imagem via software e uma outra solução que corrige a imagem em tempo real, através de um sistema de realimentação que corrige o posicionamento do scanner para cada ponto de dados da imagem. O método através da realimentação em tempo real trouxe melhores resultados, mas diminuiu a velocidade do sistema do SPM para a captação da imagem e introduziu na imagem ruídos do sensor e do sistema de controle. J. F. Jorgensen et al. [42], desenvolveram um método para medir a histerese e corrigir a imagem. Para isso, fizeram uma alteração no 
sistema do STM para que a imagem pudesse ser escaneada da superfície nos dois sentidos da direção $x$, resultando em um par de imagens de uma mesma área. Através da comparação das duas imagens, o efeito da histerese foi modelada segundo uma função quadrática, que foi interpolada com as imagens originais, produzindo imagens corrigidas. Um outro método que eles desenvolveram, faz uso da transformada de Fourier das imagens e o modelo quadrático do método anterior. Através de um algoritmo iterativo, o pico no espaço de frequências correspondente ao padrão repetitivo contido na imagem original é maximizado resultando numa imagem sem distorção.

A distorção provocada pela interação entre a ponta e a amostra ocorre devido a dilatação da amostra pela ponta [43], entre outros fatores [44] (veja a seção 2.5). Isto faz com que os detalhes contidos nas imagens pareçam mais largos do que são na realidade. Para minimizar este efeito, torna-se necessária a aplicação de métodos que estimem a geometria da ponta, e através desta geometria a imagem real pode ser reconstruída. Um dos primeiros algoritmos propostos para a solução deste problema foi o do Reiss et al. [45], supondo a forma parabolóide para a ponta. Vesenka et al. [46] publicou uma solução que é uma especialização destas geometrias particulares, ou seja, esferas, parabolóides ou elipsóides. Estas soluções baseiam-se na idéia de que superfícies não interpenetrantes em contato devem ser tangentes no ponto de contato. Para a reconstrução das pontas em geral, é necessário o cálculo numérico das inclinações. Isto tem sido difícil na prática [47], devido à introdução de ruídos através dos processos de derivação. Como alternativa, uma outra abordagem baseada em morfologia matemática tem sido usada por diversos autores $[47,48,49,50]$. Esta abordagem é aplicável a qualquer forma da ponta (ponta e amostra que possam ser expressas como um array de alturas) e que não requer derivadas numéricas.

Qualquer um desses métodos pode ser usado para reconstrução; a superfície da amostra, se a forma da ponta for conhecida ou a forma da ponta, se a superfície da amostra for conhecida. No entanto, para se estimar a forma da ponta, o requisito de que o caracterizador da espécie da ponta (por exemplo, uma grade de dimensões conhecidas) pode ser uma 
limitação. As dimensões fornecidas pelo fabricante podem não ser precisas, e esse caracterizador pode sofrer alteração durante a varredura [41]. Uma alternativa para a estimativa da forma da ponta usando caracterizadores de ponta de geometria desconhecida, foi desenvolvida por Vilarrubia [50] e Williams et al. [51]. Dongmo et al. [52] descreve uma outra técnica relacionada com essas anteriores. Estes métodos, que vieram a ser conhecidos como blind reconstruction, determinam a forma da ponta a partir da imagem sem o conhecimento a priori da forma da amostra. Fazendo-se uma boa escolha dos caracterizadores da ponta, a forma obtida a partir destes métodos se aproxima muito bem da forma real da ponta [53]. Este algoritmo foi usado em um teste [54] em que pontas de diamante foram reconstruídas e o resultado comparado com a imagem obtida através do microscópio eletrônico de varredura (SEM). Em uma outra situação [55], foram extraídas imagens de uma mesma região de um filme de propileno biaxialmente orientado, uma através de uma ponta contaminada e outra com uma ponta limpa. A ponta contaminada foi reconstruída e usada para dilatar a imagem produzida pela ponta limpa. A imagem resultante era semelhante à obtida diretamente pela ponta contaminada. Estes resultados indicaram que o método blind reconstruction reproduziu com boa precisão a forma das pontas, nos dois casos.

\subsubsection{Análise de Imagens}

Os trabalhos publicados em análise de imagens tem sido bastante diversificados, de acordo com a medida a ser feita na imagem. Convém observar que não são muitos os trabalhos publicados nesta área, envolvendo imagems de SPM. Isto demonstra a falta de intercâmbio dos grupos que trabalham com SPM com os que desenvolvem técnicas computacionais de análise.

Mesmo assim, alguns trabalhos vem sendo desenvolvidos. Dentre esses, destacam-se aqueles que envolvem medidas de contagem e comprimento de objetos $[56,57,58]$, medidas de rugosidade [59], medidas de distribuição estatística [60], dimensão fractal [61] e outras propriedades que caracterizam a amostra. 
Spisz et al. desenvolveram um método denominado SSDS (solid-state DNA sizing) para determinação do comprimento do DNA, visualizados em imagens de AFM [56, 57]. Este método envolve segmentação por limiarização, esqueletização para o afinamento e depois a somatória das distancias entre pixels conectados. Este algoritmo foi integrado ao software AFMIPS para processar centenas de DNAs em uma imagem e mais de 1500 imagens por dia. Sanchez-Sevilla et al. [62] aprimoraram este algoritmo calculando os comprimentos através da filtragem gaussiana introduzida por Cesar e Costa [63], somando distâncias reais, e assim obtendo os comprimentos de uma forma mais precisa.

Algoritmos de detecção de partículas e suas propriedades são muito úteis em diversos casos. Este trabalho geralmente é feito manualmente pelo próprio usuário, o que é bastante cansativo. Por este motivo, são desenvolvidos algoritmos que realizem esta atividade automaticamente. M. J. J. Jack et al. [58] desenvolveram um procedimento para contagem automática de nanopartículas e suas áreas. Inicialmente foi feita a subtração do background a fim de eliminar as ondulações da superfície, depois foi aplicado um limiar sobre a imagem para segmentar as partículas. Deste modo, informações de interesse tais como tamanho das partículas e a localização são determinadas. Shane E. Roark et al. [64] também fizeram contagem automática de partículas mas os pixels que definem uma partícula foram "fitados" por um elipsóide ou esferóide, através do método dos mínimos quadrados. Após isso, as propriedades das partículas foram determinadas.

\subsection{Softwares para microscopia de varredura por sonda}

O sistema que acompanha o SPM geralmente traz consigo um software para a análise e processamento das imagens, desenvolvido pelo fabricante, tais como a Park Scientific Instruments, Topometrix e a Digital Instruments. No entanto, nem sempre estes softwares trazem os recursos necessários para determinadas medidas, ou suas funções são limitadas. Também, tais programas são como uma "caixa preta", pois não se sabe exatamente como as rotinas foram implementadas. Diversos softwares vem sendo desenvolvidos com a capacidade de 
fazer medidas mais complexas, mas são distribuídos comercialmente, tornando dispendioso o seu uso. Sendo assim, alguns grupos de pesquisa viram a necessidade de desenvolver seus próprios softwares para que suas necessidades fossem atendidas. Uma das dificuldades encontradas pelos desenvolvedores é que cada fabricante do microscópio criou um formato para o arquivo da imagem, tornando difícil o desenvolvimento de um software compatível com vários formatos diferentes [65]. Mesmo assim, existem alguns softwares que são compatíveis com diversos formatos de imagens disponíveis no mercado. Alguns dos softwares que foram desenvolvidos por grupos de pesquisa são disponibilizados através de uma requisição, outros estão disponíveis para download através da home page do grupo e outros estão sendo distribuídos comercialmente, significando que o usuário precisa pagar para obter uma licença de uso. Nas seções seguintes serão apresentados os principais softwares disponíveis para processamento e análise de imagens de SPM, sendo que alguns são distribuídos livremente e outros comercialmente.

\subsubsection{Não comerciais (freewares)}

P. M. Williams desenvolveu um software denominado Genesis Graphics System [66], adotando processamento paralelo em plataformas UNIX. Este sistema possui diversas rotinas de processamento e análise, inclusive simulação da dilatação e erosão da ponta com a amostra na imagem. Posteriormente este sistema foi colocado em um servidor da web, de tal modo que usuários de todas as partes do mundo passaram a processar suas imagens do sistema através da internet [67].

O software ElbaView, desenvolvido por Igor Nevernov et al. [68], sob o paradigma da orientação a objetos, constitui um ambiente de processamento de imagens que aceita diferentes formatos. Os dados são convertidos em objetos e podem ser salvos em um único documento. Bohmig et al. [69] desenvolveu um sistema que combina os algoritmos dos pacotes Khoros (processamento de imagens e sinais) e $\mathrm{HDF}^{1}$. Esta combinação permite a

\footnotetext{
${ }^{1}$ Hierarchical Data Format, formato de arquivo independente que permite armazenar todos os dados relevantes para análise junto com o arquivo original
} 
manipulação de diferentes formatos de arquivo e possui a flexibilidade de conectar as diversas funções de processamento de imagens como módulos em um fluxograma.

Um software com algumas funções interessantes é o SPM Image Magic ${ }^{2}$, desenvolvido por Alexander Kryzhanovsky. Este software processa imagens tanto da Topometrix como da Digital Instruments fazendo um gráfico de qualquer perfil da imagem e a subtração do background, planificando uma imagem distorcida pelos efeitos da não linearidade, histerese e creep do scanner. No entanto, a função de análise de partículas, que permite a contagem e outras medidas nos objetos contidos na imagem não está disponível na versão freeware que é disponibilizada pelo autor. Outro software com funções semelhantes é o STM Analyzer, desenvolvido por Alexander Gusev e Fabrice Charra, que processa somente imagens produzidas pelos STM e SNOM.

Existem alguns softwares especializados em remover as distorções incorporadas pela dilatação da amostra pela ponta e em calibrar o sistema do SPM. Entre os que realizam a “deconvolução", encontramos o Midas ${ }^{3}$ e o Deconvo ${ }^{4}$. O Midas faz a dilatação da imagem com uma ponta cuja forma o usuário pode escolher e também a erosão de uma imagem gerada por AFM. Este software foi desenvolvido por Peter Markiewicz [70]. O Deconvo pode estimar a forma da ponta através da imagem de AFM, através do algoritmo blind estimation, publicado nos trabalhos de Vilarrubia [50, 53, 41, 54]. Também pode aplicar algoritmos de dilatação e erosão da imagem e fornecer um mapa da imagem mostrando as regiões em que há ou não certeza de que a superfície real foi reproduzida. Além desses, podemos citar o Statscan ${ }^{5}$ que calibra a medida da altura no SPM através de imagens de grade, podendo compensar as distorções provocadas pela não linearidade e histerese do scanner.

Alguns softwares foram disponibilizados para o domínio público. Isto significa que seu código fonte está disponível livremente para qualquer usuário. Isto é bastante vantajoso, pois o usuário pode alterar o código, conforme o necessário. Mesmo que não não se queira

\footnotetext{
${ }^{2}$ http://www.geocities.com/alexkryzh/

${ }^{3}$ http://www.weizmann.ac.il/surflab/peter/midas98/index.html

${ }^{4}$ http://www.siliconmdt.com/freeware/deconvo.htm

${ }^{5}$ http://www.siliconmdt.com/freeware/statscan.htm
} 
recompilar o software, o usuário pode examinar o código fonte e saber exatamente o que o programa está fazendo. Em algumas situações, a rotina de processamento só será útil se o usuário souber exatamente os detalhes do algoritmo empregado para calcular o resultado. Um exemplo neste sentido é o software DataScan [71]. Além da vantagem de ser de código aberto, foi desenvolvido em Java, sendo portanto independente de plataforma. Outro exemplo de software de domínio público é o NIH Image ${ }^{6}$. Trata-se de um aplicativo para Macintosh, de autoria de Wayne Rasband do National Institute of Health, nos EUA. Este software foi desenvolvido inicialmente para análise de imagens de obtidas por microscópios ópticos. Visto que seu código fonte foi disponibilizado para o domínio público, diversos outros programas foram feitos derivados deste. Uma de tais variações é o Image SXM ${ }^{7}$, desenvolvido por. D. Barret [65] e que processa mais de 20 diferentes formatos de arquivos gerados por microscópios de varredura. Este software pode ser customizado através de macros, pequenos textos que contém uma sequência de comandos. Isto permite que se defina uma sequência de operações a ser aplicada a um arquivo ou a uma imagem $[72,73]$.

O NIH Image foi portado para a plataforma Windows pela Scion, um fabricante de gravadores de frames de vídeos, com o nome de Scion Image ${ }^{8}$. O código fonte para esta versão não é de domínio público, portanto o software não pode ser customizado. Uma outra variação do NIH Image, é o Image $/{ }^{9}{ }^{9}$, desenvolvido também por Wayne Rasband. Este software possui as mesmas características do NIH Image e é independente de plataforma, pois foi escrito em Java. Apesar de ser voltado para análise de imagens, ainda não tem funções específicas para imagens de microscopia de varredura. No entanto, por ser de código livre, provavelmente estas funções deverão aparecer com o tempo.

Acrescentando mais um aplicativo baseado no NIH Image, há uma outra alternativa para usuários da plataforma Windows. A Nanotec Eletronica, uma companhia espanhola que fabrica microscópios de varredura por sonda, distribui uma aplicação chamada WSxM ${ }^{10}$ que

\footnotetext{
${ }^{6} \mathrm{http}: / /$ rsb.info.nih.gov/nih-image

${ }^{7}$ http://reg.ssci.liv.ac.uk

${ }^{8} \mathrm{http}: / /$ www.scion.com

${ }^{9}$ htpp://rsb.info.nih.gov/ij

${ }^{10} \mathrm{htpp}: / /$ www.nanotec.com
} 
processa os formatos dos arquivos das imagens do seu próprio sistema de SPM, e mais dois outros: os da Digital Instruments e os da Free University of Berlin. Futuras versões deverão aceitar formatos de arquivos de outros fabricantes. Assim como os outros softwares fornecidos por organizações comerciais, o código fonte não está disponível. Dentre os freewares, o WSxM é o que possui mais recursos de análise e processamento para imagens de SPM.

\subsubsection{Comerciais}

Diversas empresas têm comercializado softwares para processamento e análise de imagens. Os principais são os seguintes:

1. ForceView $200{ }^{11}$ e SPMCON ${ }^{12}$ : Estes softwares são sharewares que processam curvas de força nas imagens produzidas pelo SPM da Digital Instruments;

2. FitEdge ${ }^{13}$ : Destinado a calibração lateral e vertical das imagens de SPM e detecção dos efeitos da não linearidade e histerese do scanner. Esta calibração é feita através de imagens de estruturas cristalinas conhecidas para validar a precisão das imagens obtidas através do SPM.

3. Intelligent View ${ }^{14}$ : Este software possui várias funções de caráter geral, tanto para processamento como para análise de imagens. Isto inclui as seguintes funções :

- Processamento de imagens : Filtros para o melhoramento das imagens, redução de ruído, convolução.

- Transformada de Fourier : FFT, DFT, convolução, deconvolução, autocorrelação, filtros passa alta/passa baixa/passa banda.

- Transformada Wavelet : Transformada Discreta Wavelet (DWT) com várias wavelets.

\footnotetext{
${ }^{11}$ http://www.uni-muenster.de/Physik/PI/Fuchs/index.html

${ }^{12}$ www.wardgroup.umn.edu.software.html

${ }^{13} \mathrm{http}: / / \mathrm{www}$. siliconmdt.com

${ }^{14}$ http://www.yoonlab.com/
} 
- Morfologia Matemática : Erosão, dilatação, abertura, fechamento, esqueletização, detecção de bordas, diagrama de Voronói.

- Análise de Objetos : Identificação de objetos, extração de propriedades, etc.

- Possibilidade de customização do software para utilização de várias rotinas em de modo sequencial.

Por ser um software pago, algumas dessas funções estão desabilitadas na versão de demonstração, sendo que outras funcionam normalmente, permitindo que diversos processamentos sejam feitos.

4. SPIP - Scanning Probe Image Processor ${ }^{15}$ : Atualmente, este é o software de análise e processamento de imagens com mais recursos, pois integra todas as funções dos softwares anteriores, com mais opções, e ainda outras possibilidades. Algumas de suas funções são as seguintes :

- Calibração lateral, vertical [29] e correção das distorções provocadas pelo scanner. Utiliza o algoritmo blind reconstruction [41, 51].

- Análise da imagem por correlação, para a extração de propriedades repetitivas nas imagens.

- Análise da rugosidade através de 20 parâmetros de rugosidade.

- Correção da inclinação através da escolha de métodos e grau do polinômio

- Processsamento da maioria dos formatos de arquivos gerados pelos sistemas de SPM disponíveis no mercado e possibilidade de customização para processamento de imagens de formatos desconhecidos.

\footnotetext{
${ }^{15} \mathrm{http}: / /$ www.imagemet.com/spip/spip.html
} 


\section{Capítulo 4}

\section{Processamento de Imagens de superfícies para alinhamento de cristais líquidos}

\subsection{Introdução}

Em aplicações tecnológicas os cristais líquidos (CL) são geralmente confinados em celas para se obter o devido alinhamento. A eficiência destes dispositivos depende em grande parte de quão uniforme é este alinhamento [74]. Vários métodos de se obter um alinhamento uniforme tem sido propostos, tais como o esfregamento da superfície, grades de relevo superficiais, processo de fotoalinhamento e assim por diante. No entanto, o mecanismo do alinhamento molecular ainda não é bem compreendido [75].

Com o objetivo de entender melhor os processos por detrás destes alinhamentos, foi desenvolvido um trabalho em parceria com o Grupo de Fluidos Complexos do Instituto de Física da USP de São Paulo. Foram processadas e analisadas imagens de substratos usados para o alinhamento de cristais líquidos e imagens de cristais líquidos depositados nesses substratos, para se investigar parâmetros ópticos e morfológicos dessas amostras. Tais parâmetros afetam decisivamente na eficiência do alinhamento dos CL.

Foram analisados três tipos de substratos: PVA (poli-vinil álcool), PMMA (poli-metil metacrilato) e Teflon. Os polímeros PVA e PMMA foram depositados variando-se o processo de esfregamento e para o Teflon variou-se a temperatura de deposição. Para estes substratos, investigamos a morfologia superficial através das imagens de AFM e a qualidade 
da orientação induzida ao cristal líquido (quando confinado em celas confeccionadas com estes substratos), foi analisada através de imagens de microscopia óptica de luz polarizada. Também através deste processo foi determinada a energia de ancoramento azimutal. Sobre essas imagens foram aplicadas técnicas apropriadas de processamento e análise de imagens a fim de caracterizar as propriedades da morfologia e textura das superfícies. Este trabalho foi feito em colaboração com o aluno de doutorado Ivan H. Bechtold, o Prof. J. J. Bonvent da Universidade de Mogi da Cruzes e a Prof ${ }^{a}$. Elisabeth A. de Oliveira do Instituto de Física da USP.

\subsection{Materiais e métodos}

\subsubsection{Tratamento de superfícies}

Antes de qualquer tratamento específico as lâminas de vidro foram devidamente limpas: inicialmente as lâminas são lavadas com detergente, em seguida colocadas num ultra-som em 3 etapas consecutivas (30 minutos cada) imersas em produtos distintos (na ordem: acetona, álcool e água destilada). Finalmente, as lâminas foram enxaguadas intensamente com água destilada para remover qualquer resíduo remanescente e postas para secar num forno.

O PVA e o PMMA foram dissolvidos na concentração de $2 \%$ de massa em água e clorofórmio, respectivamente. A solução é depositada sobre as lâminas de vidro via spin coating a 3000 RPM. Após a deposição, as lâminas depositadas são deixadas por 30 minutos num forno para evaporação do solvente. Sobre estes substratos também foi utilizado processo de esfregamento, para o qual foi utilizado um pedaço de veludo comum. O esfregamento foi manual, enrolando-se um pedaço deste veludo num cilindro e deslizando-se sobre a superfície polimérica, levemente pressionado.

Para a deposição do Teflon as lâminas de vidro são aquecidas até a temperatura desejada, então desliza-se manualmente uma barra de Teflon levemente pressionada sobre as lâminas. Foram efetuadas deposições para 3 temperaturas distintas: 130,150 e $170^{\circ} \mathrm{C}$. 


\subsubsection{Técnicas experimentais}

- Microscopia de Força Atômica (AFM) para caracterizar a morfologia dos substratos estudados;

- Microscopia óptica de luz polarizada para investigar a qualidade da orientação induzida ao cristal liquido por estes substratos. Para esta análise foram confeccionadas celas com $10 \mu \mathrm{m}$ de espessura. O cristal líquido (5CB - Merck) foi introduzido por efeito de capilaridade;

- Operador de Sobel para estimar a orientação do gradiente em cada um dos pixels ao longo dos canais produzidos pelo processo de esfregamento;

- Análise dos componentes principais para determinar a orientação dos canais.

\subsubsection{Determinação da energia de ancoramento}

Foi elaborado um estudo para determinar a energia de ancoramento do cristal líquido para estes substratos, que é a energia de interação entre o cristal líquido e a superfície. Como estamos investigando superfícies que induzem uma orientação planar ao cristal líquido, queremos determinar a energia de ancoramento azimutal. Essa energia pode ser estimada através do método da cela híbrida em formato de cunha, impondo uma distorção do diretor na amostra (twist). Na lâmina de referência, foi feito o processo de esfregamento em PVA, muito estudado e bem estabelecido por diversos autores, por impor um ancoramento forte ao cristal líquido $\left(W \phi \approx 1,5 \cdot 10^{-5} \mathrm{~J} / \mathrm{m}^{2}\right)$. Na lâmina de teste depositamos o polímero para o qual deseja-se determinar a energia de ancoramento. O motivo de construirmos a cela em cunha foi o de podermos realizar medidas para distâncias distintas entre as lâminas numa mesma cela. Numa extremidade as lâminas de vidro tratadas foram unidas uma em contato direto com a outra, e na outra extremidade utilizamos um espaçador de Mylar de espessura conhecida. Veja-se a figura 4.1 abaixo.

A medida é feita com um microscópio óptico de luz polarizada, introduzindo-se a amos- 


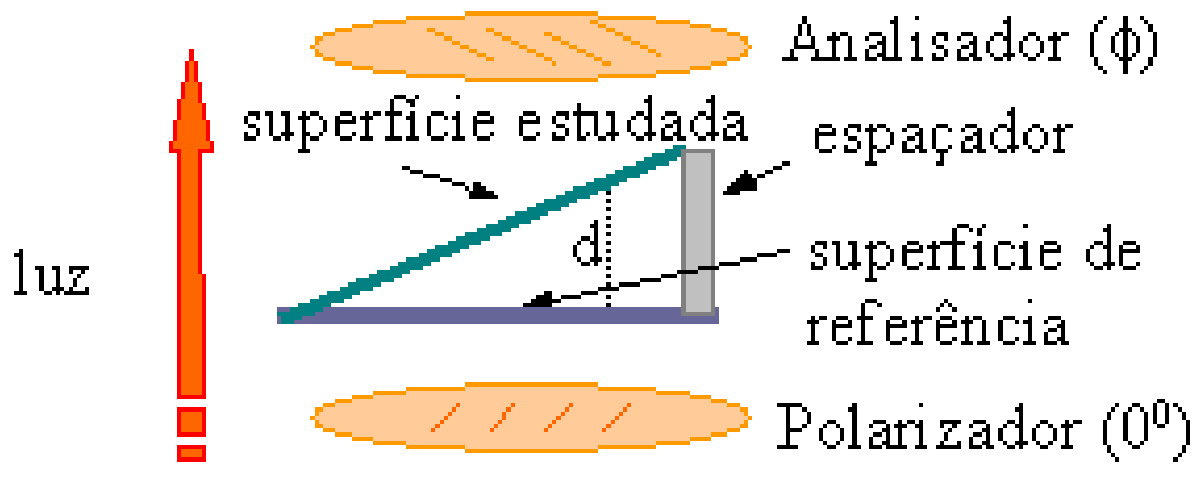

Figura 4.1: Esquema experimental para determinação da energia de ancoramento azimutal.

tra entre o polarizador e o analisador, de tal forma que a direção de esfregamento do PVA esteja paralela ao polarizador. Na superfície estudada a direção de tratamento deve ser perpendicular à direção do tratamento usado na lâmina de referência. A direção da orientação de equilíbrio do cristal líquido próximo à superfície de teste pode ser obtida girando-se o analisador até encontrar a condição de máximo de luz transmitida. A orientação é medida em termos do ângulo de twist da amostra $(\phi)$, que corresponderá ao ângulo entre a orientação imposta pelo tratamento com PVA (considerando que nessa superfície a energia de ancoramento é muito forte, ou seja, a condição inicial é mantida) e a direção de equilíbrio encontrada na outra superfície.

Quando a energia de ancoramento na superfície estudada também é forte, espera-se $\phi \approx$ $90^{\circ}$, o que representa um twist total. No entanto, se a energia de ancoramento é fraca, esperase $\phi \approx 0^{0}$, o que significa que em toda a amostra (inclusive na outra superfície) o diretor assume a direção de orientação imposta pela superfície com PVA.

O cálculo da energia de ancoramento azimutal foi desenvolvido por Valery P. Vorflusev et al. [76]. Utilizando a teoria elástica contínua para cristais líquidos, eles obtiveram que:

$$
W_{\phi}=\frac{2 K_{22} \phi}{d \sin (2 \phi)}
$$

onde $K_{22}$ é a constante elástica de twist do cristal líquido e $d$ o espaçamento entre as lâminas. 
Para o cristal líquido termotrópico 5CB, utilizado neste estudo, o valor da constante elástica é $K_{22} \approx 4 \cdot 5 \cdot 10^{-12} N$. Dessa forma, com os valores de $\phi$ e $d$ medidos é possível obter uma estimativa da energia de ancoramento azimutal para os tratamentos superficiais utilizados. Esse método é particularmente sensível para energias de ancoramento azimutal fracas $\left(W \phi \leq 5.10^{-6} \mathrm{~J} / \mathrm{m}^{2}\right)$. A energia é considerada forte para $W \phi \geq 1.10^{-5} \mathrm{~J} / \mathrm{m}^{2}$.

No caso de uma superfície com relevo periódico, a energia de ancoramento azimutal pode ser calculada teoricamente pela equação de Berreman [77]:

$$
W_{B}=\frac{2 \pi^{3} K a^{2}}{\lambda^{3}}
$$

onde $K$ é a média da constante elástica de splay e bend $\left(K \approx 1,4.10^{-11} N\right.$ para o $\left.5 \mathrm{CB}\right)$; $a$ e $\lambda$ são a amplitude e a periodicidade dos sulcos, respectivamente. Para obter bons resultados com este método é importante que a periodicidade da superfície seja bem regular.

\subsubsection{Processamento das imagens}

O método aqui empregado visa extrair maiores informações das imagens de AFM dos substratos estudados, utilizando métodos numérico-computacionais de análise de imagens. Nesse processo, a imagem de AFM é processada para a segmentação de objetos de interesse dentro da imagem, que neste trabalho são canais superficiais devido ao tratamento superficial. Em seguida, são realizadas uma série de medidas geométricas dos objetos segmentados e os resultados obtidos são usualmente organizados em histogramas para uma melhor visualização das tendências globais exibidas pela medida. O pré-processamento e segmentação dos objetos de interesse, bem como os quatro tipos de medidas escolhidos para a superfície, estão descritos na figura 4.2. Todas estas etapas de processamento são feitas através do software SPIA. Não foi feita a análise das imagens do PVA, visto que os canais criados através do processo de esfregamento não foram muito pronunciados. No entanto, o substrato será útil para a determinação da energia de ancoramento dos outros substratos, para efeito de comparação. 


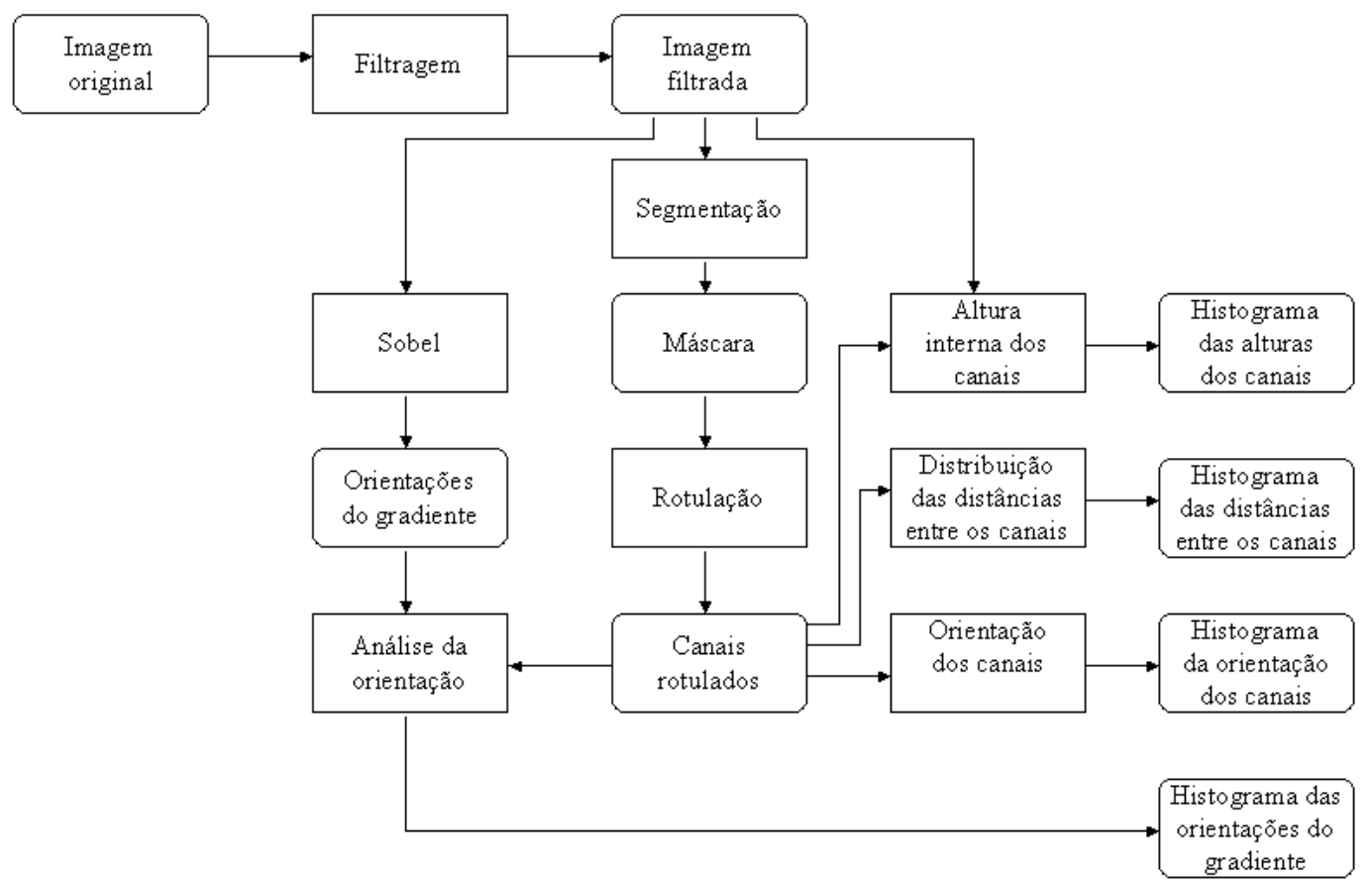

Figura 4.2: Representação dos processos (retângulos) e dados (caixas arredondadas) envolvidos na análise dos canais superficiais estudados.

O pré-processamento, a segmentação dos canais, bem como as quatro medidas escolhidas para caracterizar os substratos são descritas a seguir. Também serão comentadas as razões físicas para sua escolha e a respectiva base matemática e a implementação computacional.

\section{Pré-processamento das imagens e segmentação.}

A fim de se reduzir o ruído inerente ao processo de captação da imagem no sistema do AFM, o filtro da mediana $[3,6]$, é aplicado nas imagens. Este filtro tem-se mostrado bastante eficiente em imagens de AFM [43, 114].

Considerando que os objetos de interesse são os canais ao longo do substrato, a imagem filtrada é a seguir processada para se isolar cada canal. Este processo é conhecido por segmentação e neste caso foi feito manualmente. Foi adotada esta opção a fim de se garantir que os canais fossem efetivamente selecionados. A figura 4.3 mostra a imagem original e a imagem segmentada. A parte em cinza, é a que corresponde na imagem original aos canais. Estas imagens segmentadas são chamadas de máscaras. 

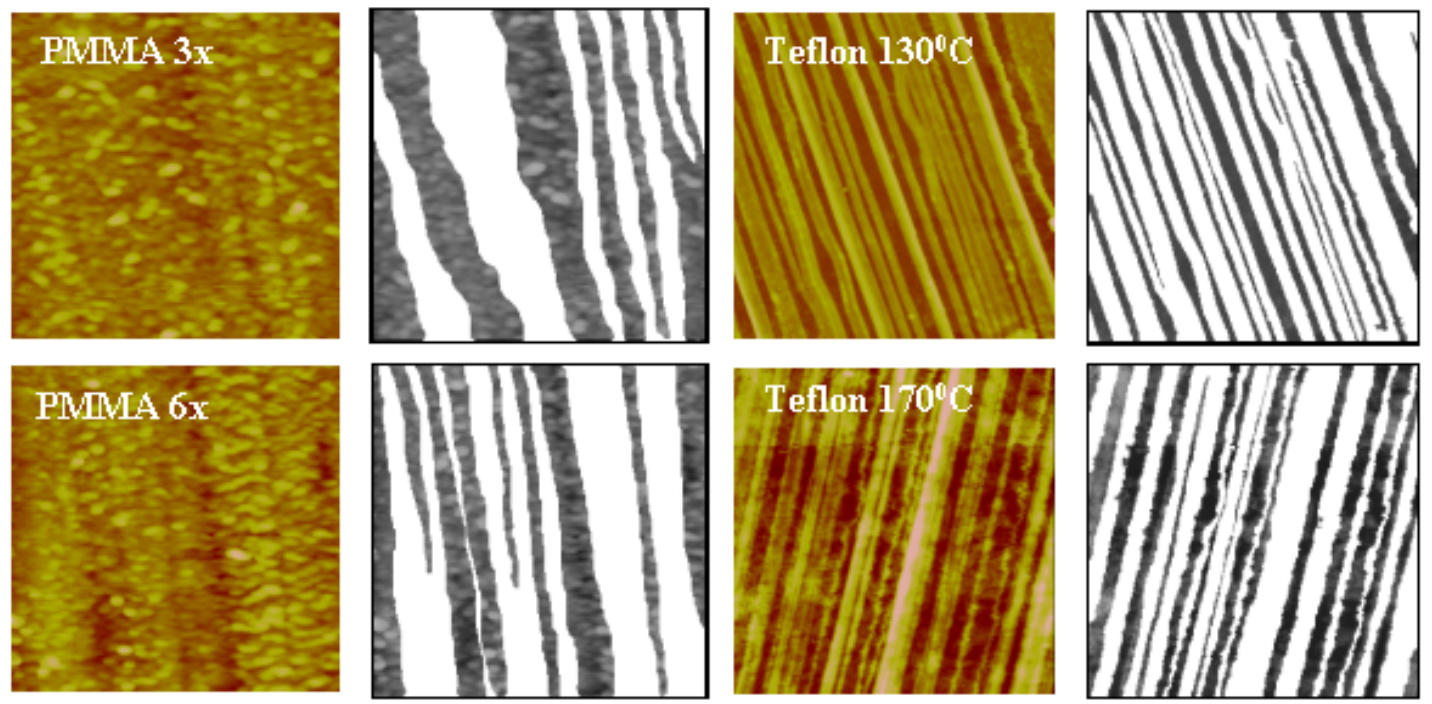

Figura 4.3: Segmentação das imagens de AFM. Esquerda: Imagem original. Direita: Canais segmentados. Varredura: 3 × $3 \mu \mathrm{m}^{2}$.

A próxima etapa no processo é a rotulação onde os canais são rotulados de tal modo que se possa obter medidas individuais dos pixels de cada canal ou de todos os canais ao mesmo tempo. As medidas que serão apresentadas a seguir, são baseadas nos pixels dos canais contidos nessas máscaras.

\section{Distribuição de alturas}

Esta medida representa um aspecto geométrico importante para a caracterização dos canais. Foram obtidos histogramas das alturas ao longo de todos os canais que possibilitarão avaliar a homogeneidade dos canais (veja a figura 4.7).

\section{Distribuição da orientação dos canais.}

Como estamos investigando o efeito dos canais no processo de orientação de cristais líquidos, é importante realizar medidas que caracterizem esta distribuição. Isto é feito aplicando-se a análise dos componentes principais [6] sobre cada canal isolado, que fornecerá a orientação preferencial (ou eixo principal). A abordagem que envolve a determinação dos eixos principais é de grande utilidade para se estudar as características das formas. Nesta técnica, a direção em que cada forma é mais alongada (ou seja, a direção em que há maior dispersão 
dos pixels da forma) é conhecida como eixo maior. Perpendicular ao eixo maior, encontra-se o eixo menor. O eixo maior e menor compreendem os eixos principais.

Neste caso, os vetores aleatórios correspondem às coordenadas dos pixels da forma. O procedimento para a obtenção dos eixos principais envolve o seguinte : Uma forma qualquer é representada por um conjunto de pontos, $\left\{\left(x_{1}, y_{1}\right),\left(x_{2}, y_{2}\right), \ldots,\left(x_{n}, y_{n}\right)\right\}$, tanto do interior como do contorno. Estas coordenadas poderão ser dispostas em uma matriz $S$ de ordem $n \mathrm{x}$ 2. A matriz de covariância $K$ da matriz $S$ pode ser obtida através da equação,

$$
K=\frac{1}{N} S^{T} S-\vec{\mu}_{\vec{X}}\left(\vec{\mu}_{\vec{X}}\right)^{T}
$$

onde $\vec{\mu}_{\vec{X}}$ é um vetor cujos elementos são as médias das coordenadas $x$ e $y$ da forma. Os eixos principais da forma, terão a mesma orientação dos autovetores de $K$. O autovetor associado com o maior autovalor possui a inclinação do eixo principal enquanto que o outro autovetor terá a inclinação do eixo menor. Esta operação produz o efeito de estabelecer um novo sistema de coordenadas cuja origem está no centróide do conjunto de pontos e seus eixos estão na direção dos autovetores de K. [3, 6].

\section{Orientações internas}

Dada a influência de um canal específico no processo de organização das moléculas de cristal líquido, a presença de pequenas estruturas (por ex: pequenos domínios poliméricos) ao longo dos canais pode afetar a orientação, por isso é importante a quantificação das orientações internas dos canais. Para isso, foi utilizado o operador de Sobel [3, 6], através do qual é possível estimar a orientação do gradiente em cada um dos pixels ao longo dos canais segmentados.

O vetor gradiente de um campo escalar $2 D$ diferenciável $z=g(x, y)$ é o vetor dado pela equação : 


$$
\vec{\nabla} g(x, y)=\frac{\partial g}{\partial x} \hat{i}+\frac{\partial g}{\partial y} \hat{j}
$$

o módulo deste vetor será :

$$
\nabla g(x, y)=\left[\left(\frac{\partial g}{\partial x}\right)^{2}+\left(\frac{\partial g}{\partial y}\right)^{2}\right]^{1 / 2}
$$

O vetor gradiente de um campo escalar $2 D$ aponta para a direção da variação máxima da função, em cada ponto específico $(x, y)$. Aplicando em imagens, a orientação do vetor gradiente irá fornecer o grau de homogeneidade da superfície. Baixos valores de inclinação indicam uma superfície plana e altos valores uma superfície com regiões íngremes.

Aplicando em imagens, consideremos uma vizinhança qualquer representada pela seguinte região da figura 4.4 (a):

\begin{tabular}{|l|l|l|}
\hline$Z_{1}$ & $Z_{2}$ & $Z_{3}$ \\
\hline$Z_{4}$ & $Z_{5}$ & $Z_{6}$ \\
\hline$Z_{7}$ & $Z_{8}$ & $Z_{9}$ \\
\hline
\end{tabular}

(a)

\begin{tabular}{|c|c|c|}
\hline-1 & -2 & -1 \\
\hline 0 & 0 & 0 \\
\hline 1 & 2 & 1 \\
\hline
\end{tabular}

(b)

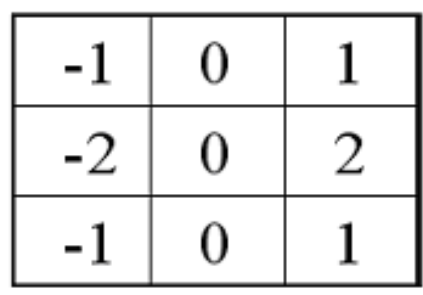

(c)

Figura 4.4: (a) Região 3 x 3 da imagem; (b) máscara usada para calcular $\partial g / \partial x$; (c) Máscara usada para calcular $\partial g / \partial y$. Estas máscaras são conhecidas como operadores de Sobel.

Os z's representam os valores em tons de cinza. A equação 4.4 pode ser aproximada no ponto $z_{5}$ de várias maneiras. $\mathrm{O}$ modo mais simples é usar a diferença $\left(z_{5}-z_{8}\right)$ na direção $x$ e $\left(z_{5}-z_{6}\right)$ na direção $y$. Neste caso, o módulo do gradiente será :

$$
\nabla g(x, y)=\left[\left(z_{5}-z_{8}\right)^{2}+\left(z_{5}-z_{6}\right)^{2}\right]^{1 / 2}
$$

A direção do gradiente será obtida por,

$$
\alpha(x, y)=\arctan \left(\frac{\frac{\partial g}{\partial y}}{\frac{\partial g}{\partial x}}\right)
$$


onde o ângulo $\alpha$ é medido em relação ao eixo $x$.

Uma outra maneira de se calcular as derivadas parciais é através do método do operador de Sobel. A vantagem deste operador é que além de diferenciar ele suaviza o processo da diferenciação. Visto que as derivadas provocam ruídos, o processo de suavização representa uma vantagem para o operador de Sobel. De acordo com a figura 4.4 as máscaras de derivada baseadas no operador de Sobel são :

$$
\frac{\partial g}{\partial x}=\left(z_{7}+2 z_{8}+z_{9}\right)-\left(z_{1}+2 z_{2}+z_{3}\right)
$$

e

$$
\frac{\partial g}{\partial y}=\left(z_{3}+2 z_{6}+z_{9}\right)-\left(z_{1}+2 z_{4}+z_{7}\right)
$$

onde os $z^{\prime} s$ são os níveis de cinza dos pixels que são sobrepostos pelos elementos das máscaras. O cálculo das derivadas parciais em relação ao pixel do centro da máscara permite a determinação da orientação do vetor gradiente para este pixel bem como o módulo do vetor. Para conseguir o próximo valor, a máscara é centralizada no próximo pixel da imagem, e se repete o mesmo procedimento. Esta sequência continua até que todos os pixels sejam processados pelo operador. No final, os valores das inclinações são apresentados em histogramas.

\section{Distribuição espacial}

Esta medida nos mostra quão regulares são as distâncias entre os canais. Isto é importante porque as posições relativas entre os canais influenciam na organização das moléculas de cristal líquido. Em cada máscara foi calculada a distancia entre os sulcos adjacentes na horizontal, para cada linha da imagem. Todas as distancias entre os sulcos são mostrados através de histogramas ( veja a figura 4.8). 


\subsection{Resultados experimentais e discussão}

A figura 4.5 mostra as imagens tridimensionais dos substratos, obtidas através do AFM.

Pode-se perceber as diferenças de relevo entre os tratamentos de superfície utilizados e as medidas de rugosidade para cada substrato.
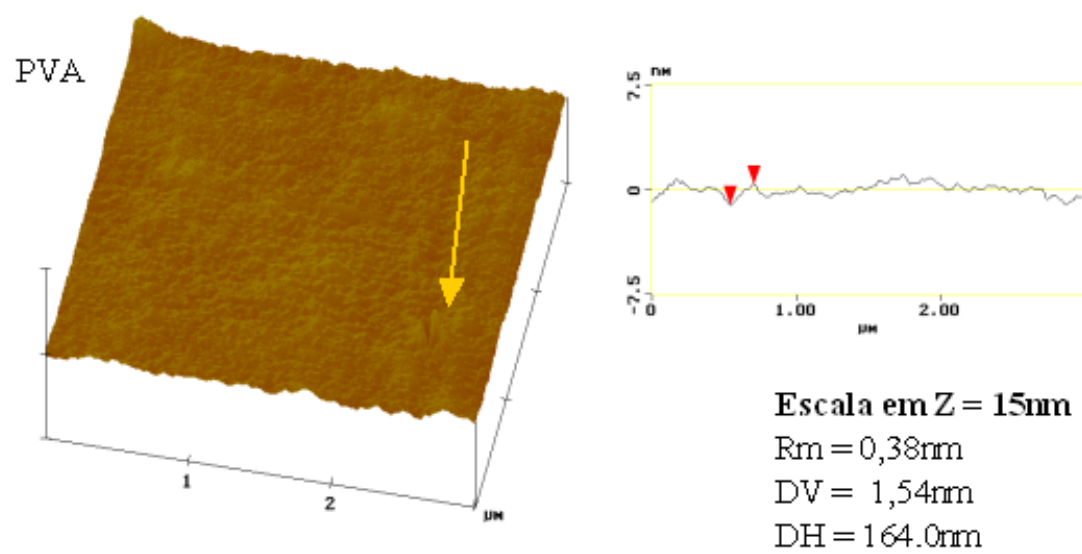

(a)
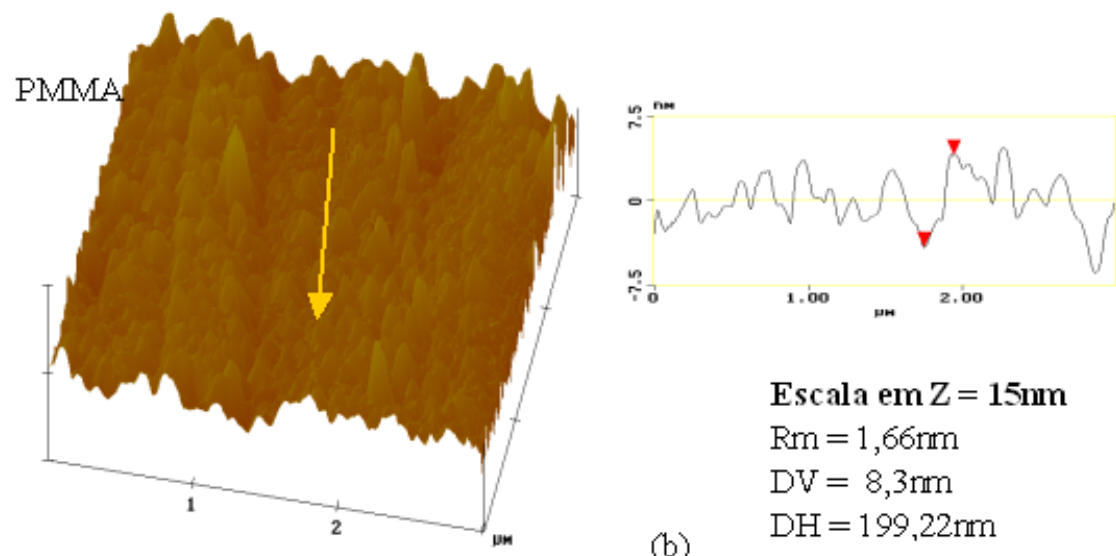

Escala em $\mathrm{Z}=15 \mathrm{~nm}$

$\mathrm{Rm}=1,66 \mathrm{~nm}$

$\mathrm{DV}=8,3 \mathrm{~nm}$

(b)

$\mathrm{DH}=199,22 \mathrm{~nm}$
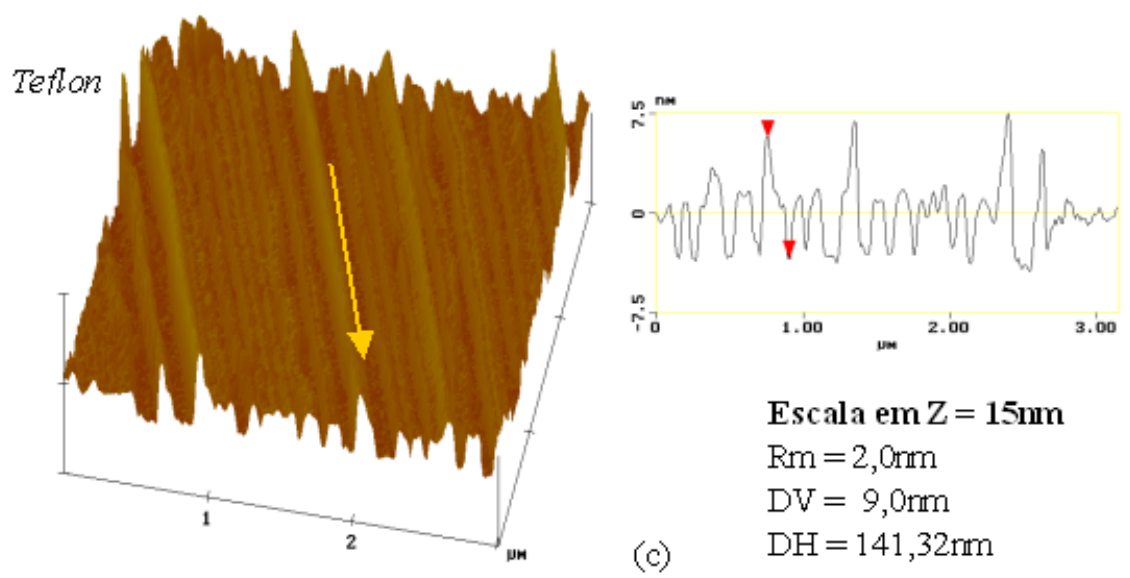

Figura 4.5: Imagens das superfícies. (a) PVA, (b) PMMA, (c) Teflon. 
As setas amarelas indicam as direções de esfregamento no caso do PVA e do PMMA e a direção de deposição no caso do Teflon. Ao lado de cada imagem encontra-se uma figura obtida por um corte transversal às direções de tratamento juntamente com os dados da rugosidade média (RM), distância vertical (DV) e distância horizontal (DH). DV e DH referem-se à posição da seta vermelha no corte transversal em cada caso. É possível notar que o PVA apresenta a superfície menos rugosa $(\mathrm{RM}=0,38 \mathrm{~nm})$, enquanto que o Teflon possui a mais rugosa $(\mathrm{RM}=2,0 \mathrm{~nm})$ e com um relevo mais regular.

As diferenças morfológicas devido ao tratamento em uma mesma superfície são estudadas com o processamento de imagens apresentado anteriormente. Investigamos as variações morfológicas devido ao processo de esfregamento sobre o filme de PMMA e da temperatura de deposição no filme de Teflon.
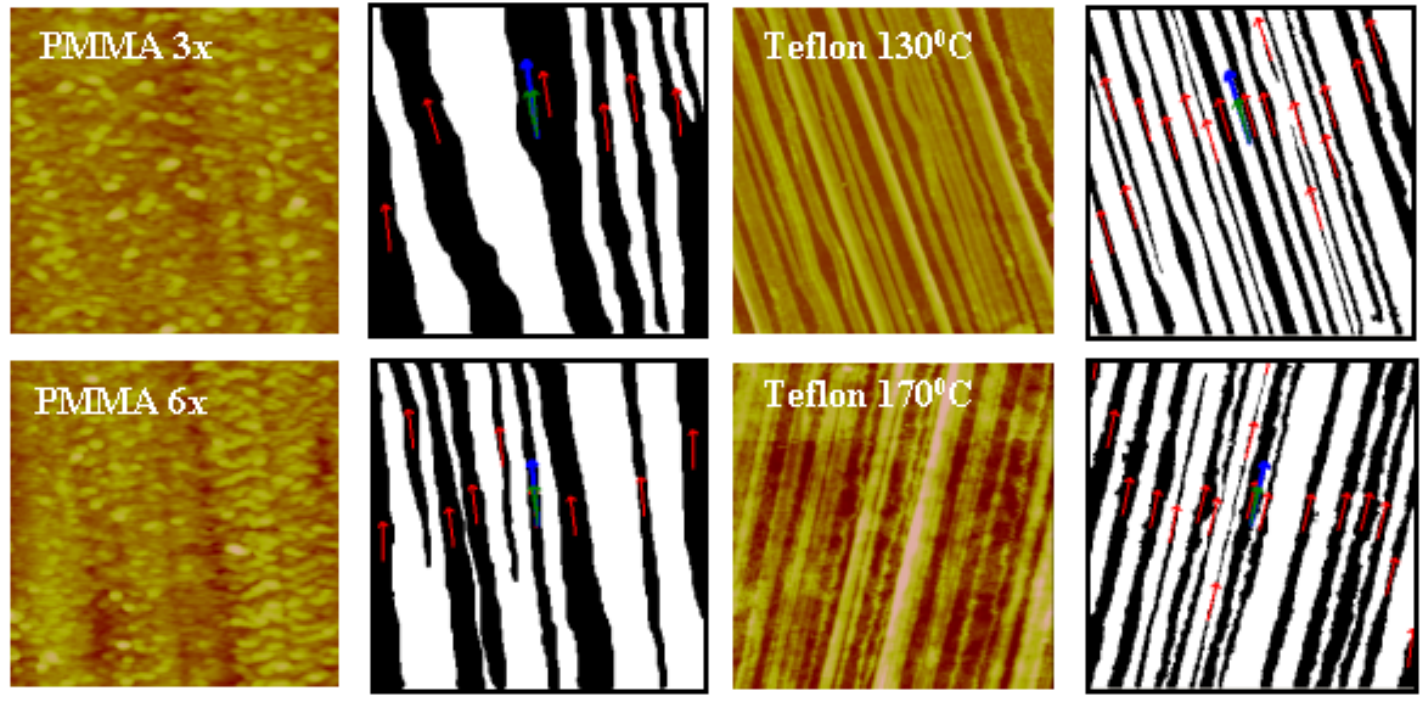

Figura 4.6: Orientações dos canais nos substratos em imagens de AFM. PMMA 3x e 6x representam quantas vezes foi efetuado o processo de esfregamento.

A figura 4.6 apresenta as orientações dos sulcos através do algoritmo de análise dos componentes principais. As imagens da direita (branco e preto) são imagens binárias das imagens segmentadas mostradas na figura 4.3. No nosso estudo, o interesse está em caracterizar os canais formados pelos processos de tratamento superficial. As setas indicam as orientações dos canais, de acordo com a direção de tratamento.

A tabela 4.1 indica o número de canais, orientação média dos canais e o desvio padrão, 
para cada uma das imagens.

Tabela 4.1: Medidas das orientações dos canais.

\begin{tabular}{|c|c|c|c|}
\hline & $n^{o}$ de canais & orientação média (graus) & desvio padrão \\
\hline PMMA (3x) & 6 & 100,33 & 4,57 \\
\hline PMMA (6x) & 9 & 96,13 & 2,56 \\
\hline Teflon $\left(130^{0}\right)$ & 20 & 109,53 & 1,42 \\
\hline Teflon $\left(170^{0}\right)$ & 18 & 77,61 & 1,93 \\
\hline
\end{tabular}

Estes dados mostram que o Teflon obteve orientações mais uniformes, com um desvio padrão menor. Já o PMMA 3x obteve o desvio maior, indicando uma menor homogeneidade em relação aos outros substratos.

A partir da segmentação das imagens pode-se caracterizar a distribuição das alturas e das orientações dos pixels ao longo dos canais. O resultado desta análise está representado em forma de histogramas, figura 4.7. As alturas são representadas em tons de cinza (0 a 255) e ângulo de orientação varia de 0 a $180^{\circ}$.

Com respeito às distribuições das alturas ao longo dos canais (figura 4.7(a)) podemos observar que quando o processo de esfregamento é aumentado (3x para 6x, PMMA), a altura máxima dos canais aumenta, no entanto a maior quantidade de pontos se encontra aproximadamente no mesmo patamar de altura (110). No caso do aumento da temperatura de deposição do Teflon (130 para $170^{\circ} \mathrm{C}$ ), a altura máxima praticamente não se altera, mas a maior quantidade de pontos passa para um patamar mais alto (90 para 110). A largura dos histogramas nesta medida está relacionada com a homogeneidade na profundidade dos canais.

Analisando a distribuição de orientações internas dos canais (figura 4.7(b)) no Teflon, observa-se que ela é composta na maior parte de baixos ângulos ou próximos de $180^{\circ}$. Isto significa que o relevo interno destes canais é aproximadamente plano, sem grandes variações de altura. Isto se harmoniza com os histogramas de altura do Teflon, que são estreitos e concentrados na altura de 100 (em tons de cinza). O mesmo não ocorre para o PMMA. Há uma grande variação das orientações, havendo um pico em torno de $90^{\circ}$. Isto indica que a superfície dos canais é bastante irregular, com variações bruscas de altura. Esta informação 


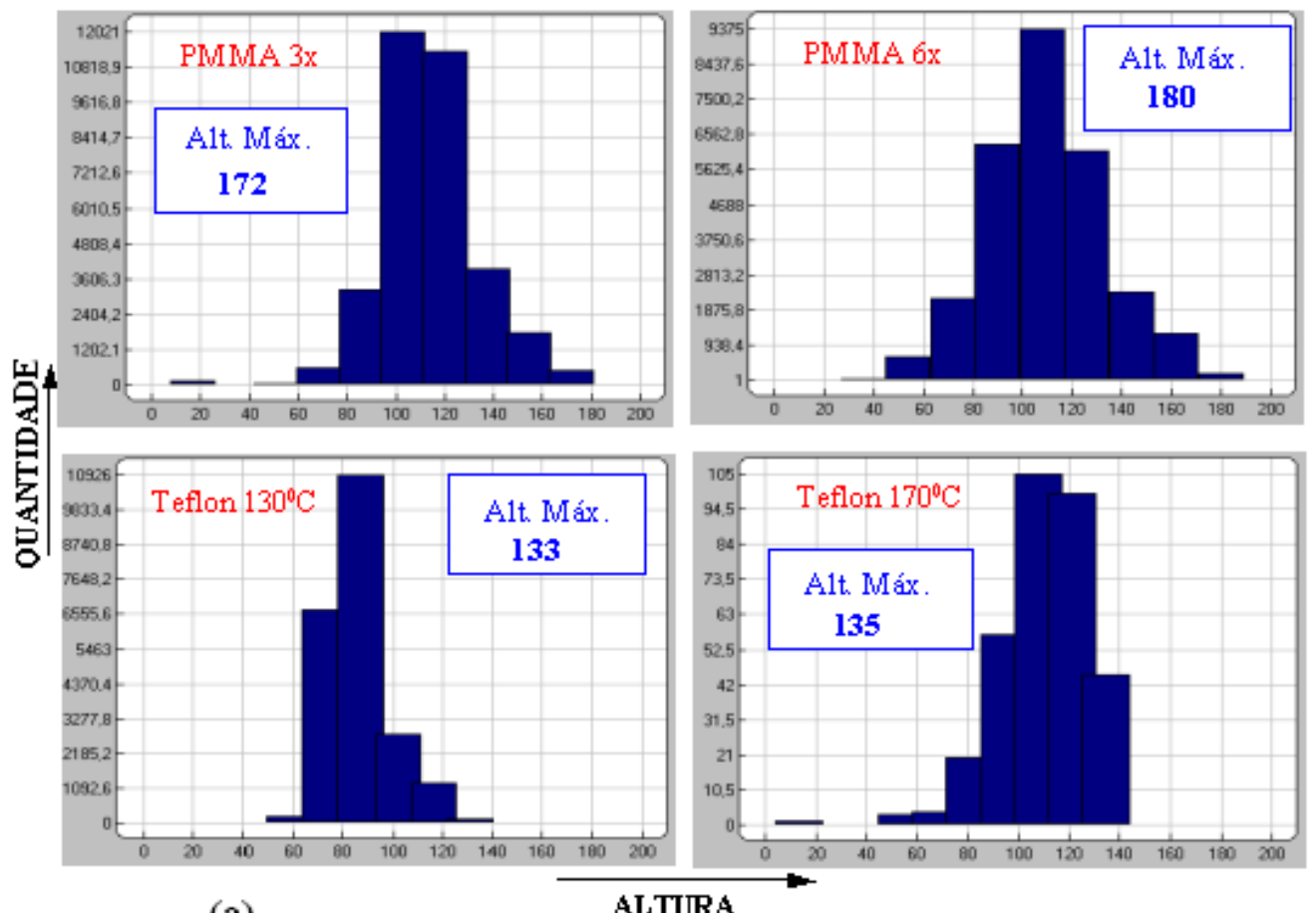

(a)

ALTURA

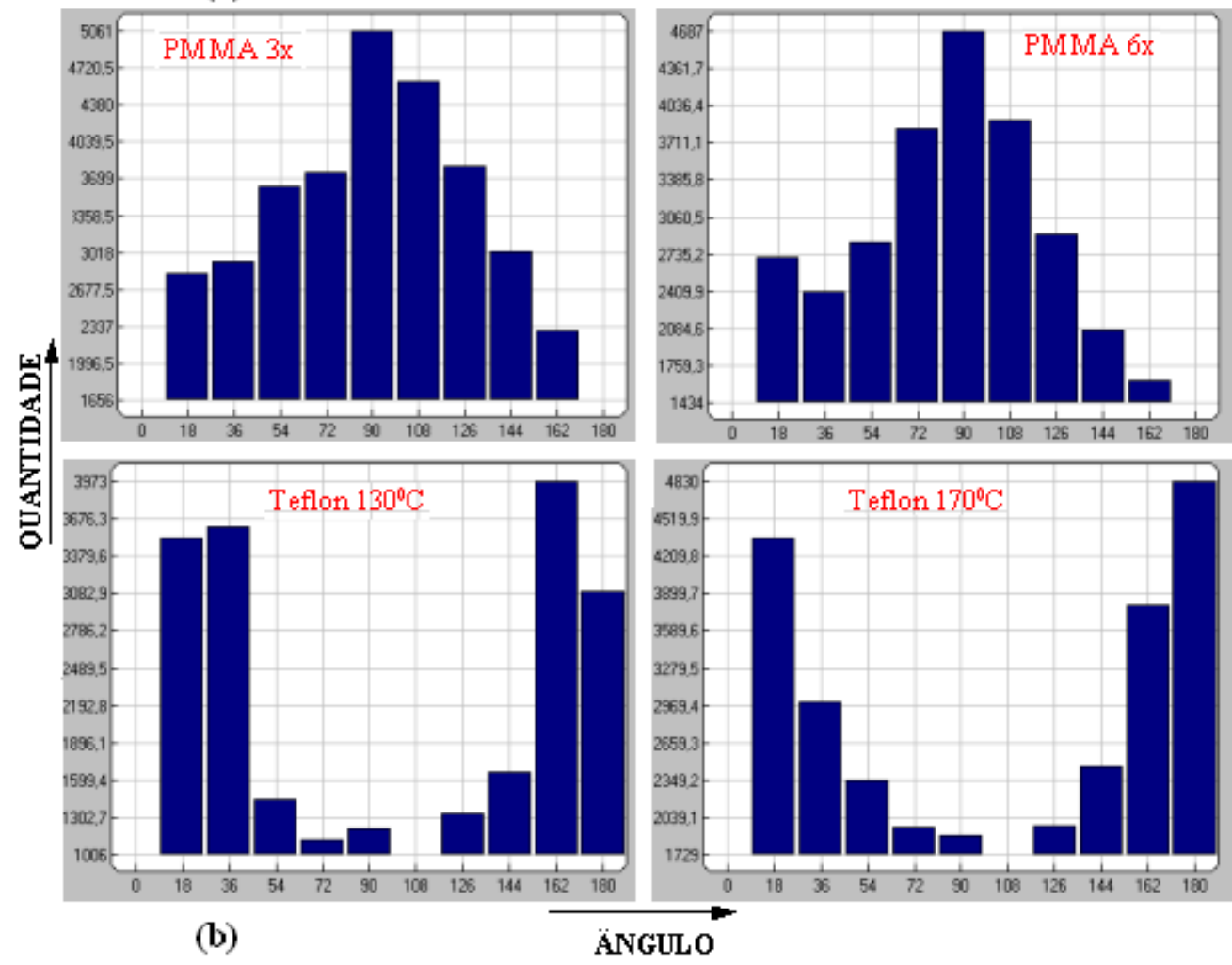

Figura 4.7: Representação em histogramas. (a) Distribuição das alturas ao longo dos canais, em tons de cinza; (b) orientação interna dos canais. O ângulo refere-se a orientação do vetor gradiente de cada pixel ao longo dos canais com o plano horizontal. 
também é confirmada pelos histogramas de altura que são mais largos.

Os histogramas das distâncias entre os sulcos também caracterizam os substratos, figura 4.8. Comparando estes histogramas com as imagens segmentadas da figura 4.3 vemos que estão relacionadas. Para o PMMA 3x os histogramas indicam uma predominância de distâncias menores devido à metade dos sulcos estarem espaçados regularmente. Já o PMMA 6x possui uma distribuição maior de distancias apesar de também haver uma predominância de distâncias menores. Já o Teflon observa-se através das imagens que os canais são mais regulares e isto é comprovado pelos histogramas pois há uma concentração de distâncias menores.

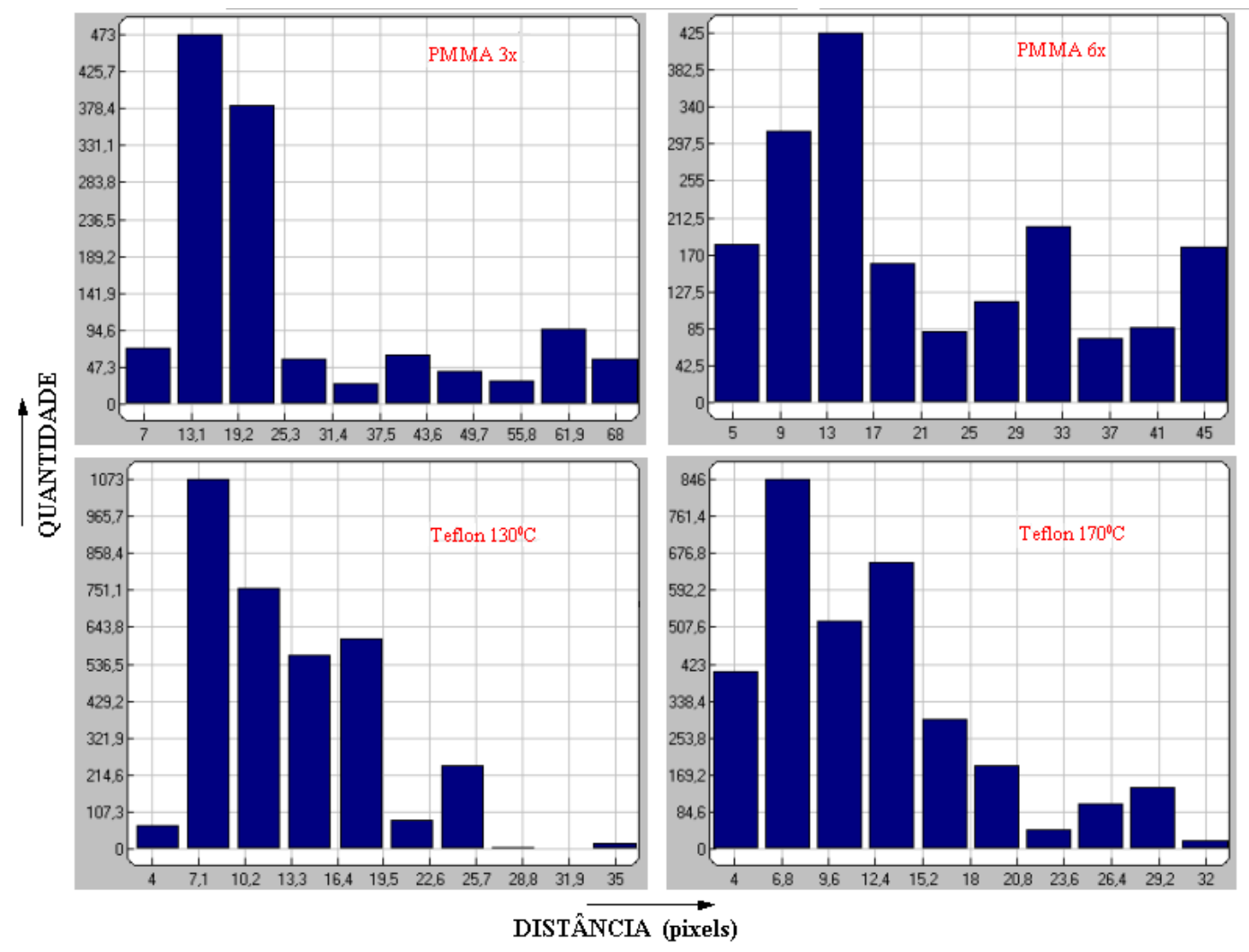

Figura 4.8: Distâncias entre os sulcos, em unidades de pixels.

Os resultados da caracterização dos substratos com o processamento de imagens mostrados na figura 4.7, podem ser relacionados com medidas do cristal líquido confinado em celas confeccionadas com estes substratos. Confeccionamos celas de $10 \mu \mathrm{m}$ de espessura para avaliar a orientação induzida ao cristal líquido por estes substratos. As imagens de textura também foram limiarizadas para facilitar a visualização, figura 4.9. 

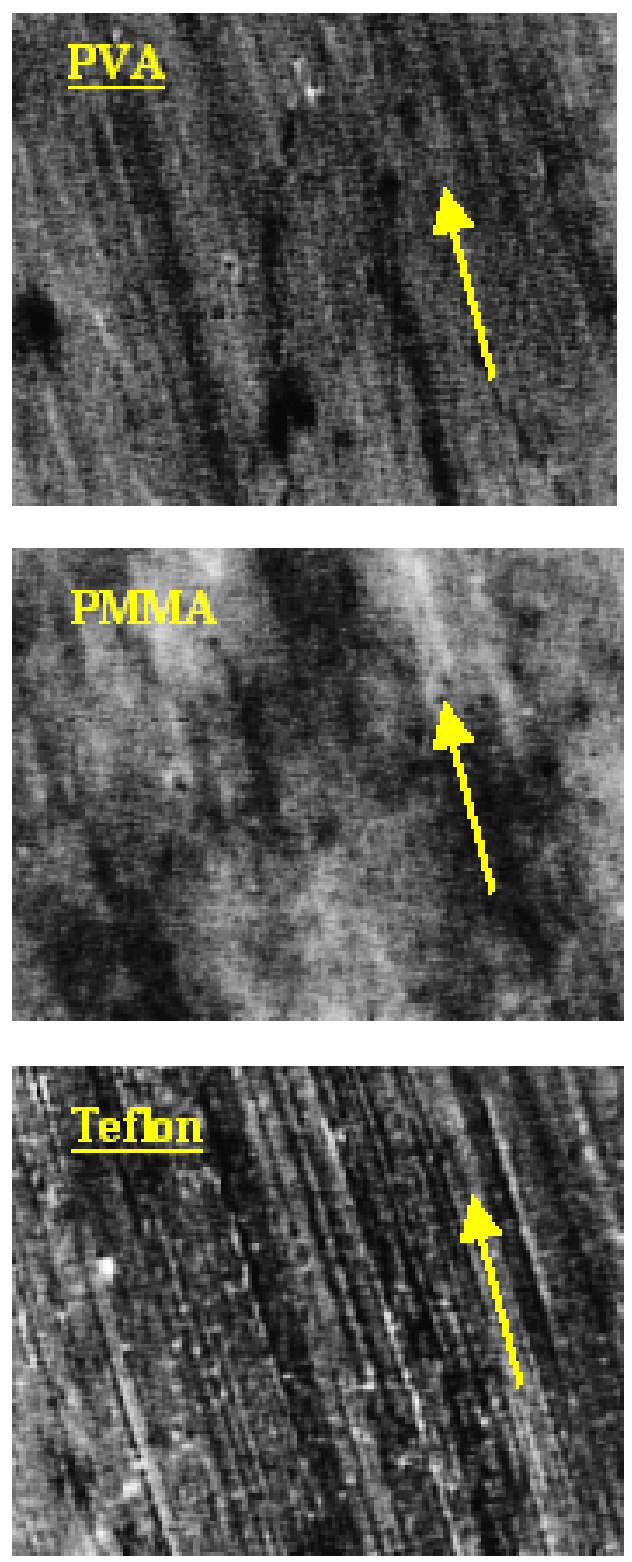
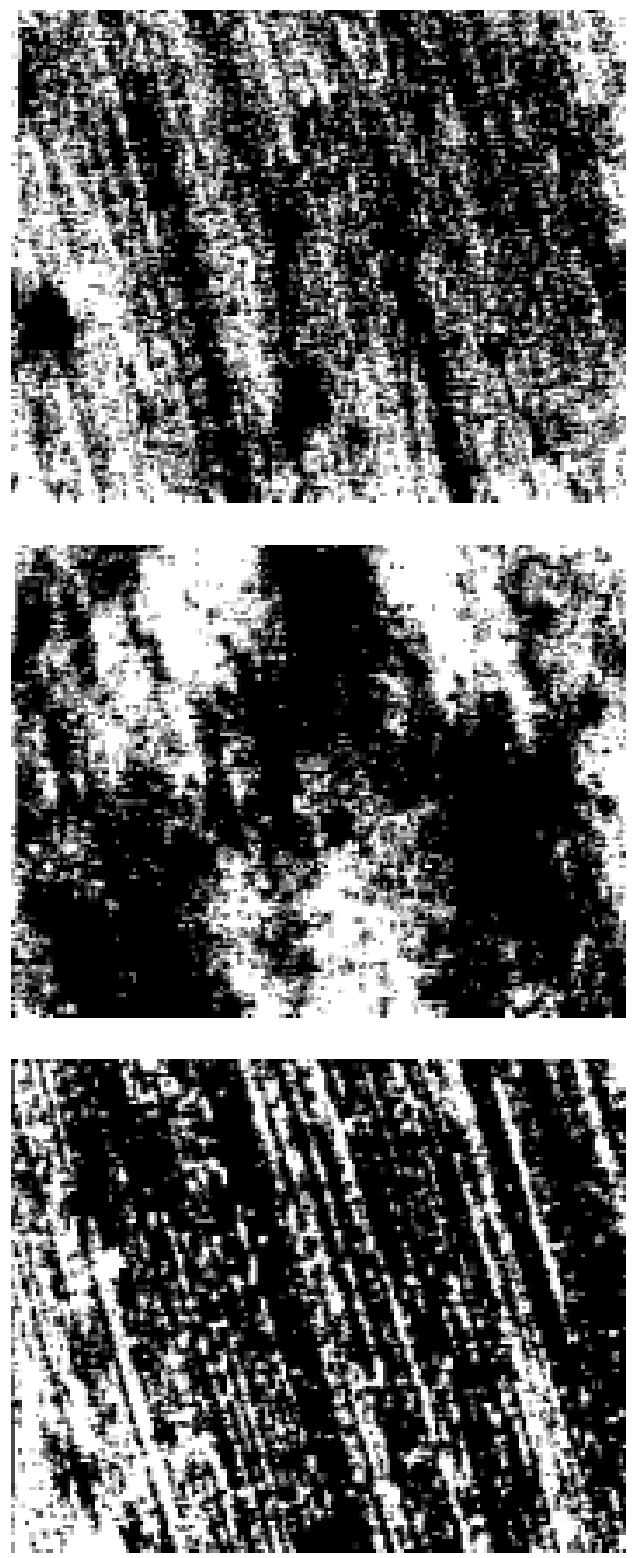

Figura 4.9: Textura do cristal líquido sobre os substratos estudados: PVA, PMMA e $T e$ flon. À esquerda: Imagens originais obtidas por microscopia óptica. À direita: Imagem limiarizada. Varredura: $1 \times 1 \mathrm{~mm}^{2}$.

Na figura 4.9 é possível observar que as características do substrato são transmitidas para a textura do cristal líquido. Dessa forma, como o filme de PVA apresenta a superfície menos rugosa (ver imagens de AFM, figura 4.5), induz uma orientação mais homogênea ao cristal líquido. No entanto, o PMMA apresenta a textura menos homogênea, apesar de sua rugosidade não ser a maior. Podemos associar isso à distribuição de orientação mais localizada dos canais do filme de Teflon (figura 4.7(b)). 
Depois de 3 meses, a orientação induzida ao CL pelo PVA permaneceu a mesma, enquanto que no caso do PMMA e do Teflon, observou-se uma diminuição na qualidade da orientação. Isto indica que a interação das moléculas de CL com o substrato de PVA é mais forte.

A energia de ancoramento azimutal para os substratos de PMMA e Teflon, juntamente com a variação em seu tratamento, foi determinada utilizando o método da cela híbrida apresentado anteriormente. Os valores obtidos estão apresentados na Tabela 4.2. No caso do filme de Teflon, como o relevo superficial apresenta uma boa periodicidade, fizemos o cálculo com a equação de Berreman (equação 4.2), para efeito de comparação.

Tabela 4.2: Energia de ancoramento para os substratos PMMA e Teflon

\begin{tabular}{|c|c|c|c|c|c|}
\hline & PMMA(3x) & PMMA(6x) & Teflon $\left(130^{0} \mathrm{C}\right)$ & Teflon $\left(150^{0} \mathrm{C}\right)$ & Teflon $\left(170^{0} \mathrm{C}\right)$ \\
\hline $\mathrm{W} \phi\left(J / m^{2}\right)$ & $1.1 \times 10^{-6}$ & $1.3 \times 10^{-6}$ & $1.0 \times 10^{-5}$ & $8.9 \times 10^{-6}$ & $6.2 \times 10^{-6}$ \\
\hline $\mathrm{W}_{B}\left(J / m^{2}\right)$ & - & - & $5,1.10^{-7}$ & $1,7.10^{-7}$ & $5,8.10^{-8}$ \\
\hline
\end{tabular}

Comparando-se os valores da energia de ancoramento azimutal obtidos para os dois substratos (PMMA e Teflon, Tabela 4.2), observa-se que esta energia é maior para o filme de Teflon. Este fato parece estar relacionado com a maior homogeneidade dos canais, como obtido a partir do processamento das imagens de AFM (figura 4.6).

Para o PMMA a energia de ancoramento é aumentada quando o processo de esfregamento sobre a superfície é aumentado. Da caracterização dos canais superficiais, obtivemos que a altura máxima dos canais e a distribuição das alturas dos canais superficiais criados pelo esfregamento aumentam (figura 4.7). Isso quer dizer que à medida que os canais se tornarem um pouco mais altos, os defeitos ao longo dos canais também aumentam. Essas características deveriam diminuir a energia de ancoramento, no entanto, se observa o contrário. Isso quer dizer que para este substrato a morfologia da superfície parece não ter muita influência. Este aumento de energia então se dá pela formação de cargas superficiais pelo processo de esfregamento, como observado por Matsuda [79]. Este fenômeno é também confirmado por Bechtold et al [80]. Neste caso, pode-se concluir que os canais não desempenham o papel mais importante para a energia de ancoramento azimutal do cristal 
líquido.

No caso do Teflon, o aumento da temperatura de deposição implica na diminuição da energia de ancoramento azimutal. Esta observação está de acordo com o que esperávamos através do resultado das análises do processamento das imagens de AFM, onde a profundidade máxima dos canais praticamente não se altera, por outro lado, ocorre um aumento no número de defeitos ao longo dos canais (figura 4.7).

Os valores das amplitudes $a$ e períodos $(\lambda)$ necessários para fazer o cálculo da energia de ancoramento azimutal $\left(W_{B}\right)$ com a equação 4.2 , foram obtidos com um corte transversal à direção dos canais nas imagens de AFM dos filmes de Teflon, ver figura 4.10. Os valores calculados também estão apresentados na Tabela 4.2.

Para os filmes de PMMA não foi possível fazer os cálculos de $W_{B}$ com a equação 4.2, devido à baixa regularidade da periodicidade superficial. As diferenças obtidas utilizando os dois métodos de determinação da energia de ancoramento azimutal são perfeitamente justificáveis se considerarmos que o método da cela híbrida é uma medida macroscópica da interação do cristal líquido com a superfície como um todo, enquanto que a equação de Berreman se apóia no relevo local considerando-o reprodutível por toda a superfície. No caso de uma superfície perfeitamente periódica os dois valores certamente são praticamente iguais.

\subsection{Conclusões}

As medidas de microscopia de força atômica (AFM) forneceram dados sobre a morfologia da superfície que, depois de tratados, puderam ser comparados com observações da textura induzida ao cristal líquido por estas superfícies e da energia de ancoramento. Observamos que a superfície de Teflon apresenta o relevo mais regular, com canais bem definidos (da ordem de $300 \mathrm{~nm}$, dependendo da temperatura de deposição) na direção de deposição, enquanto que o PVA apresenta a superfície menos rugosa. As imagens de textura 4.9, mostram que a superfície de PVA apresenta a orientação mais homogênea. O que se observa para to- 


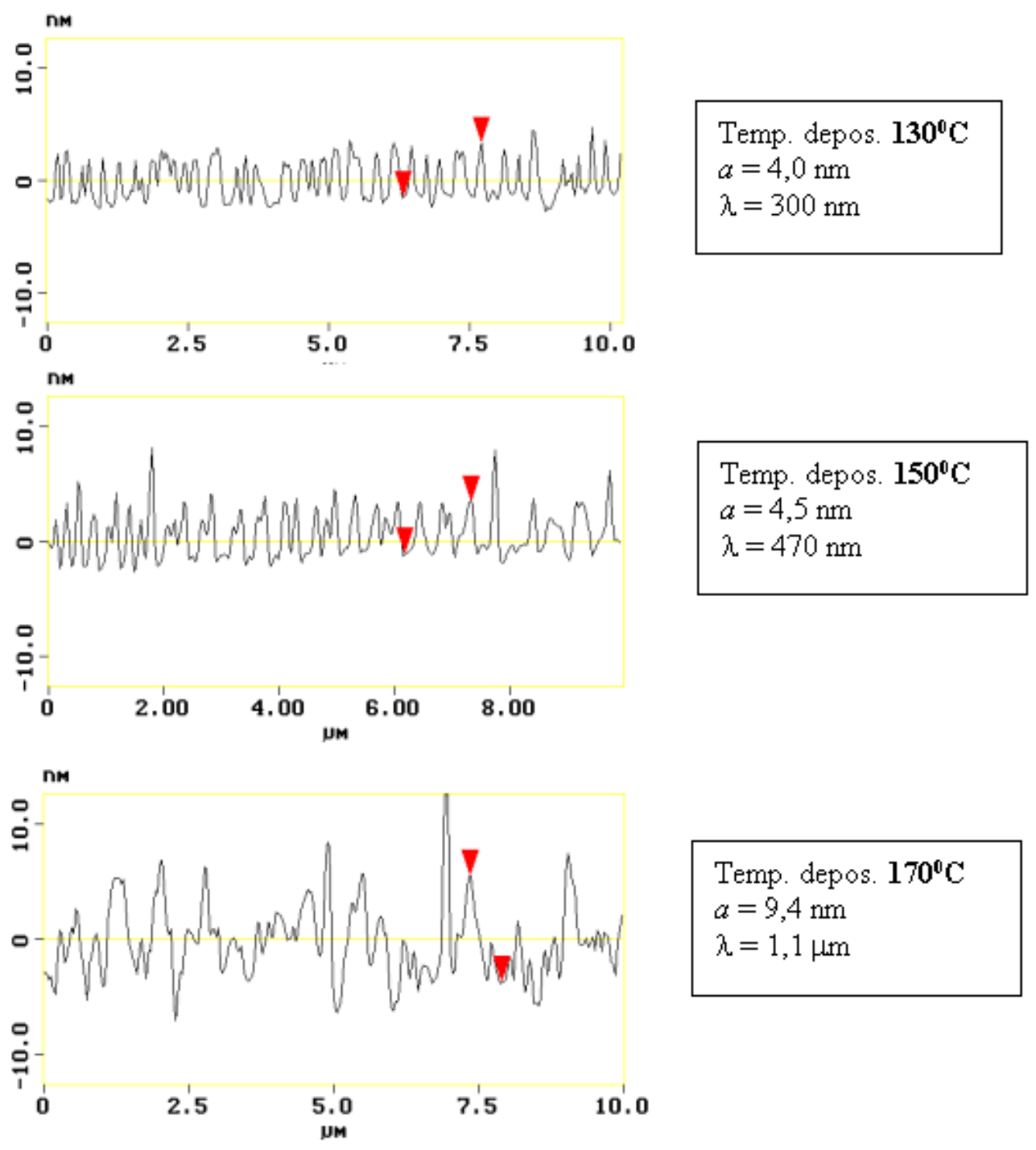

Figura 4.10: Corte transversal aos canais dos filmes de Teflon, nas imagens de AFM.

dos os tratamentos é uma relação direta entre as características da superfície com a qualidade da orientação das moléculas de cristal líquido.

Também constatamos com o processamento de imagens que aumentando o número de vezes o processo de esfregamento, as irregularidades ao longo dos canais na superfície de PMMA aumentam, dificultando o processo de orientação dos CL. Ao contrário do que se esperava, a energia de ancoramento aumentou. Isso está relacionado com a formação de cargas na superfície devido ao esfregamento [80] e não a existência dos canais.

O aumento da temperatura de deposição do Teflon aumenta a espessura do filme e torna 
a superfície mais irregular. A caracterização da morfologia ao longo dos canais mostrou que a profundidade relativa aumentou, bem como, o aparecimento de defeitos. Neste caso, como esperado,a energia de ancoramento diminuiu.

Os valores da energia de ancoramento azimutal obtidos para o PMMA estão no regime de energias consideradas fracas ( $W \phi \leq 5 \cdot 10^{-6} \mathrm{~J} / \mathrm{m}^{2}$ ), enquanto que o PVA e o Teflon se encontram no regime de energias consideradas fortes $\left(W \phi \geq 1.10^{-5} \mathrm{~J} / \mathrm{m}^{2}\right)$. Portanto, podemos concluir que a formação de canais não é o fator mais relevante para a energia de ancoramento dos cristais líquidos, outros fatores como interações moleculares (essas interações dependem da composição química dos materiais) entre o cristal líquido e a superfície a formação de cargas devido ao processo de esfregamento são dominantes no caso do PMMA. No caso do PVA não existem cargas induzidas por esfregamento [80] e por este motivo a sua energia de ancoramento é devido somente às interações moleculares. Os resultados deste trabalho foram publicados em [81, 78]. 


\section{Capítulo 5}

\section{Caracterização da morfologia de filmes LBL POMA/PVS}

\subsection{Introdução}

A microscopia de varredura por sonda (SPM) tem sido uma ferramenta útil para a investigação da morfologia de filmes finos e em alguns casos para a análise dos mecanismos de formação dos filmes $[82,83]$. Isto é particularmente importante para filmes poliméricos produzidos através da técnica de automontagem LBL (layer-by-layer) eletrostática [84, 85, 86, 87], através da qual os filmes multicamadas são obtidos alternando-se camadas de polímeros de cargas diferentes. A microscopia de força atômica (AFM), em particular, permite estimar a rugosidade média, que depende do processo de adsorção na formação da multicamada [88]. Por exemplo, filmes LBL fabricados através de polieletrólitos fortemente carregados são molecularmente finos e homogêneos na escala nanométrica [89]. Nestas multicamadas, a adsorção é governada por interações iônicas. No entanto, em polímeros tais como polianilinas, as interações secundárias também contribuem para a adsorção. Deste modo, as ligações $\mathrm{H}$ em polianilinas podem criar camadas adsorvidas mais espessas do que com fortes polieletrólitos [90]. A rugosidade pode também ser considerada alta, com valores iguais ao da espessura de várias camadas [91].

Em geral, a análise da morfologia dos filmes envolve a extração de informação quantitativa através das imagens de SPM ou AFM, tais como parâmetros de rugosidade, ta- 
manho dos aglomerados e dimensão fractal. Embora estas medidas já forneçam dados úteis, elas deixam de capturar importantes propriedades da morfologia da superfície. Neste capítulo, será apresentado um método para a caracterização da morfologia de filmes automontados de soluções de ácido polivinil sulfônico, PVS, como polieletrólito aniônico e poli(o-metoxianilina), POMA, [103] como polieletrólito catiônico. Foi estimada com razoável precisão a natureza polidispersa dos domínios globulares do filme de POMA. Os softwares convencionais para análise de imagens são capazes de estimar apenas o número e a área dos glóbulos para específicos cortes na superfície da imagem, que são obtidos usualmente por limiarização. Uma melhor estimativa para o número e área dos glóbulos pode ser obtida utilizando uma técnica que leva em consideração diversos cortes na superfície da imagem a fim de analisar todo o relevo tridimensional e não apenas determinada altura. Neste estudo, empregamos um método baseado em dois conceitos de análise de formas, a saber, segmentação hierárquica dos glóbulos da imagem seguido pelo particionamento generalizado de Voronoi do espaço da imagem. A primeira parte do método analisa a imagem a partir da sua altura máxima para baixo, identificando e contando cada pico existente em toda a superfície. A segunda parte usa o conceito de dilatações exatas [92] para propagar fronteiras cujo centro é a coordenada do pico. Através deste método, o espaço da imagem é particionado de tal forma que qualquer ponto na região particionada está mais próximo do pico central do que qualquer outro. Este particionamento da imagem permite estimar as áreas dos glóbulos contidos na imagem. Os raios dos glóbulos são obtidos dos raios de círculos de área igual à das partições. A seguir serão apresentados os algoritmos envolvidos no método, sua aplicação em imagens de filmes de polímeros LBL juntamente com a discussão dos resultados e a conclusão. Este trabalho foi feito em colaboração com a aluna de doutorado Nara C. de Souza e o Prof. Osvaldo N. Oliveira Jr. do Instituto de Física da USP de São Carlos. 


\subsection{Análise de imagens de AFM de filmes LBL POMA/PVS}

A abordagem para análise de imagens empregada aqui envolve duas etapas principais: Determinação das coordenadas dos picos e o particionamento da imagem em um diagrama de Voronoi. A estatística dos raios dos círculos equivalentes será usada para caracterizar a distribuição dos glóbulos nos filmes.

\subsubsection{Determinação das coordenadas dos picos}

A imagem do polímero a ser caracterizado é mostrada na figura 5.1. Trata-se de uma superfície definida pela agregação de vários domínios esféricos. Nesta imagem foi aplicado antes o filtro da mediana a fim de reduzir os ruídos introduzidos pela ponta do AFM.

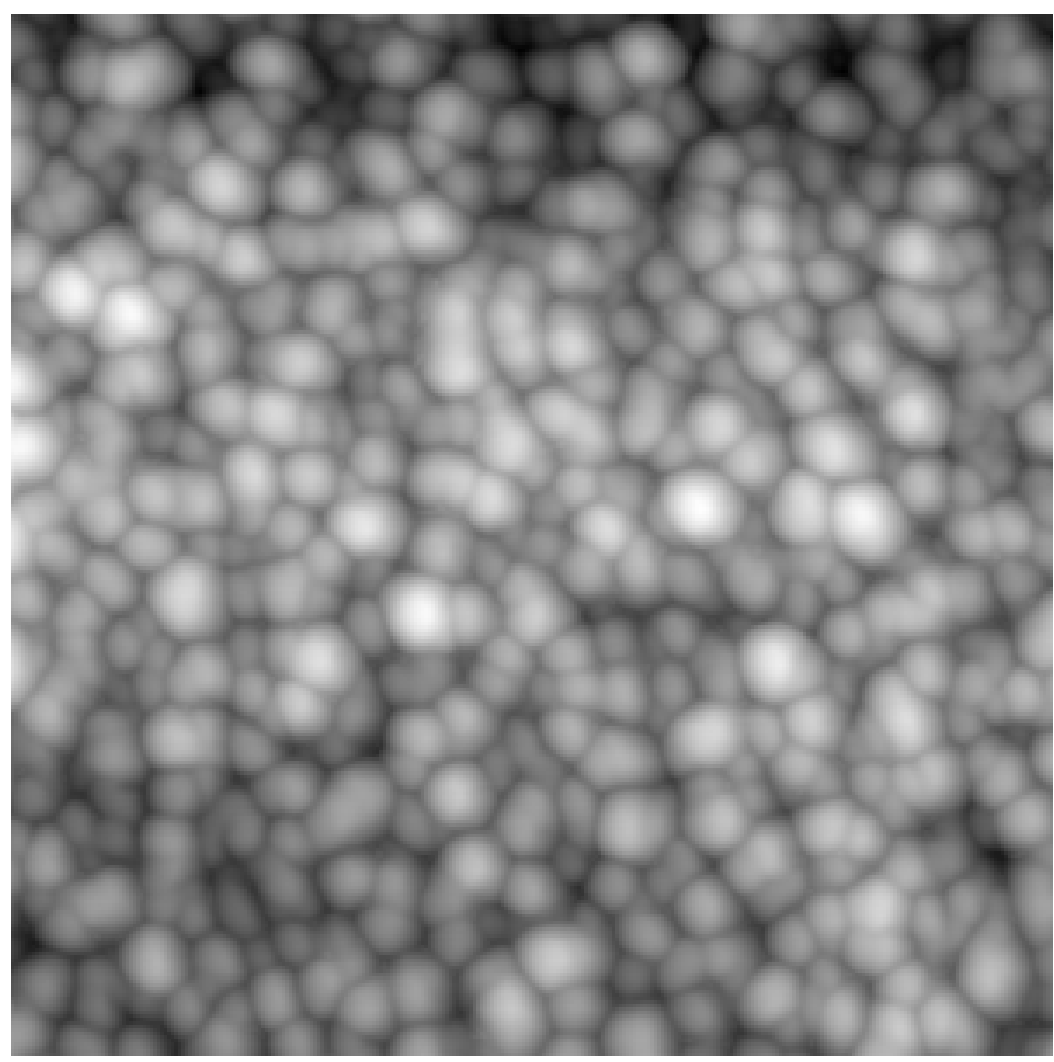

Figura 5.1: Imagem de AFM do filme POMA/PVS. Varredura: $1 \mathrm{x} 1 \mu \mathrm{m}^{2}$.

Para identificar cada um desses glóbulos, adotamos uma técnica relacionada ao conceito dos máximos regionais [93], baseado no fato de que a maioria dos domínios é convexa. O método envolve a procura por componentes conexos em imagens binárias obtidas por se li- 
miarizar a imagem em diversas alturas ou tons de cinza, em sentido decrescente. No software SPIA, o usuário tem a opção de escolher quantos cortes poderão ser feitos na imagem. Para cada subsequente limiar ou corte, cada componente conectado é identificado procurando todos seus pontos e seus vizinhos. Cada pico contido em cada um desses componentes é obtido através do centro de massa do respectivo componente. Visto que os domínios são convexos, a evolução de um componente conectado à medida que a altura diminui implica que cada novo corte conterá os mesmos componentes anteriores e possivelmente novos componentes. A figura 5.2 ilustra o resultado de três cortes na imagem da figura 5.1 e os respectivos componentes conexos. As imagens foram limiarizadas nos limiares 240, 210 e 194 (tons de cinza), respectivamente.

A figura 5.3 mostra a contagem para 100 cortes resultando numa contagem de 366 picos na imagem. O software coloca um ponto vermelho sobre cada pico encontrado.

Apesar da simplicidade do algoritmo, a maioria dos glóbulos foi identificada. Deve-se observar no entanto que, como os glóbulos não correspondem a esferas perfeitas, os pontos não estão exatamente no centro.

\subsubsection{Dilatações exatas}

As dilatações exatas têm sido úteis para estimar diversas propriedades das formas, tais como dimensão fractal $[94,95]$ e esqueletos multiescala $[94,95,96,92]$. Neste estudo, a dilatação exata foi utilizada para obter o diagrama discreto de Voronoi para os glóbulos da figura 5.1. O conceito de dilatação exata, introduzido em [95], permite a determinação precisa de todas as dilatações, correspondentes a cada raio $R$, dos pontos de qualquer objeto em uma grade de N-dimensões. Embora tais dilatações sejam simples em espaços contínuos, a situação é mais complicada em redes ortogonais, onde apenas um número menor de distâncias é possível.

Para ilustrar, consideremos uma forma constituída de um único ponto isolado, conforme a figura 5.4(a). Se começarmos a dilatar este único ponto com o primeiro raio possível, $R=1$, a primeira dilatação será representada pela figura 5.4(b). Isto quer dizer que todas 


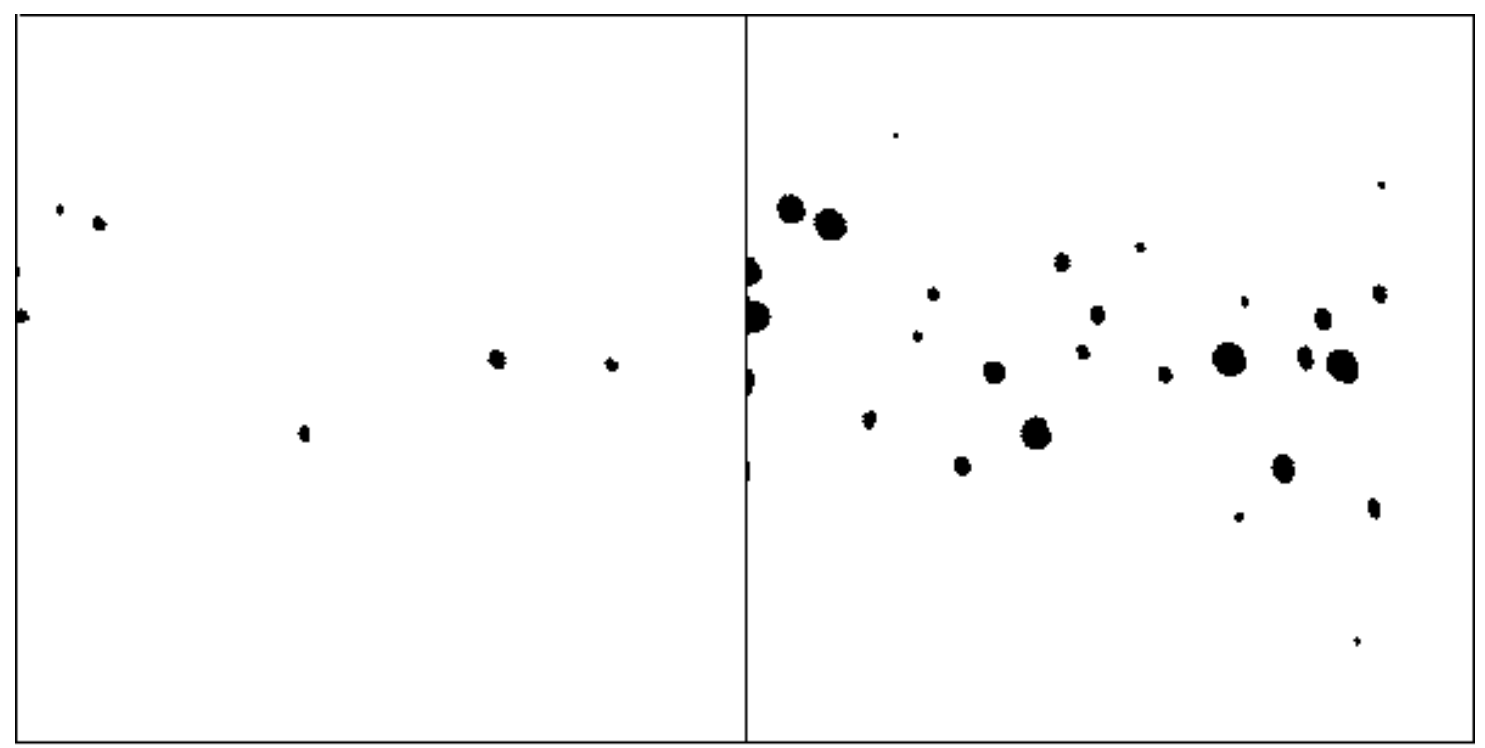

(a)

(b)

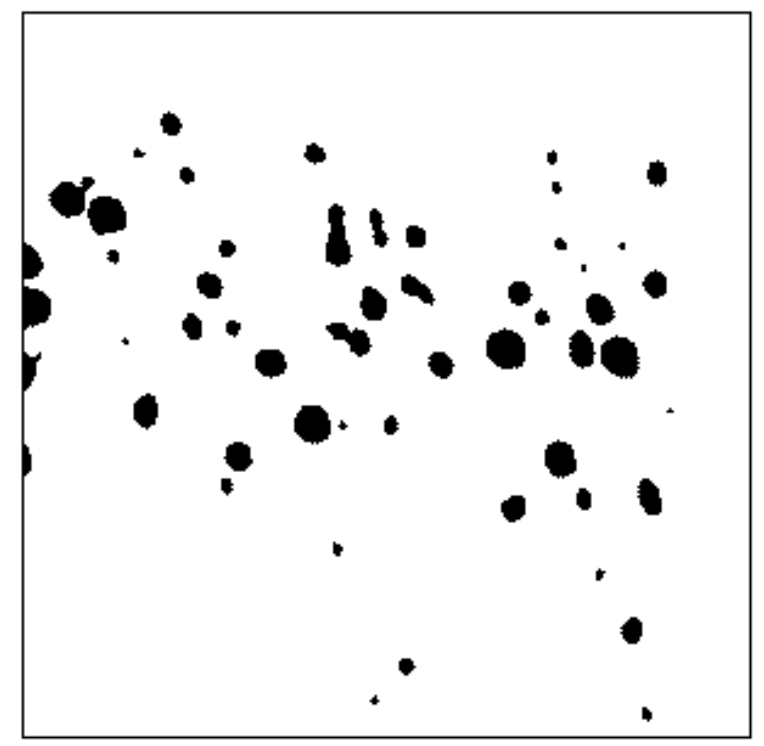

(c)

Figura 5.2: Três cortes na imagem. (a) Limiar 240, 7 componentes conexos, (b) Limiar 210, 29 componentes conexos, (c)Limiar 194, 55 componentes conexos.

as dilatações com $0<R<1$ produzem o mesmo ponto isolado da figura 5.4(a). À medida que aumentamos $R$, a próxima alteração será verificada somente para $R=\sqrt{2}$, produzindo a forma dilatada na figura 5.4(c).

Nota-se claramente que devido à natureza discreta da rede, somente uma parte do conjunto infinito de raios contínuos será permitida. Os raios assim definidos são chamados distâncias exatas. O algoritmo desenvolvido guarda uma lista das distâncias possíveis bem 


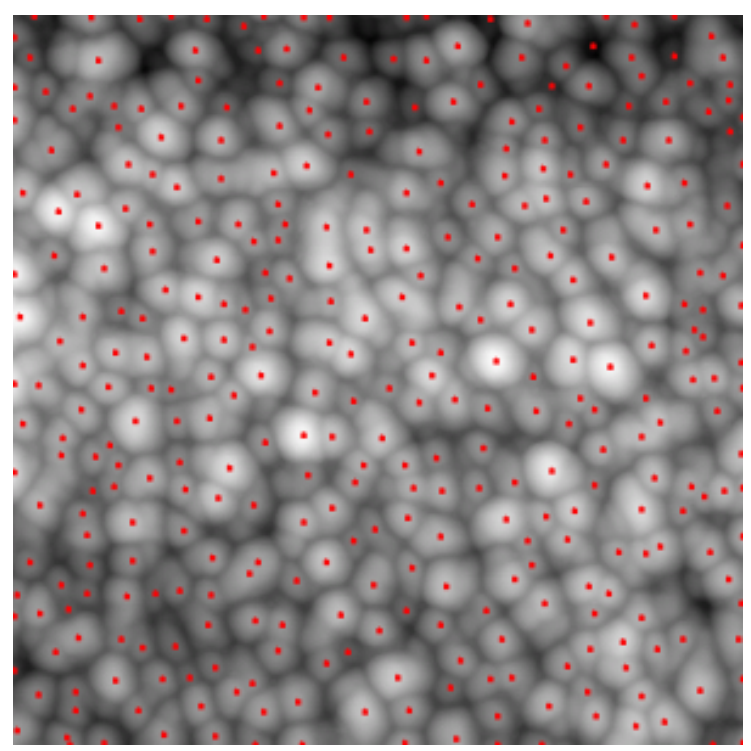

Figura 5.3: Contagem dos picos na imagem. Para 100 cortes, foram encontrados 366 picos, para um tempo de processamento de 5 minutos (Pentium III, 800MHz).

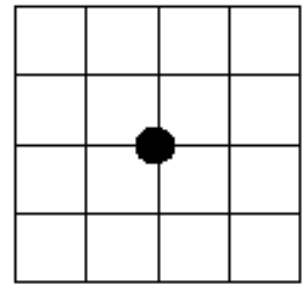

(a)

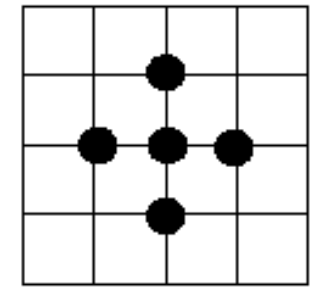

(b)

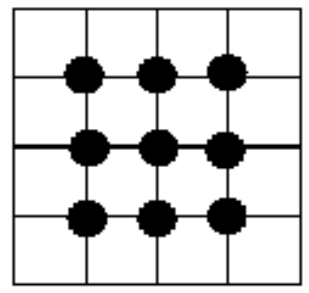

(c)

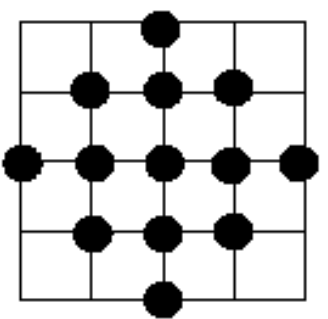

(d)

Figura 5.4: Dilatação exata. (a) Ponto a ser dilatado. (b) Dilatação para $R=1$. (c) Dilatação para $R=\sqrt{(2)}$. (d) Dilatação para $R=2$.

como as coordenadas dos pontos correspondentes a estas distâncias. A tabela 5.1 contém as quatro primeiras distâncias calculadas em relação a um ponto em $(0,0)$, e as coordenadas dos pontos correspondentes a estas distâncias.

Esta lista de distâncias bem como as coordenadas dos pontos é chamada de representação das distâncias Euclidianas ordenadas (sorted Euclidian distance representation, SEDR), pelo fato de considerar a métrica Euclidiana para o cálculo das distâncias. A forma dilatada do ponto da figura 5.4 (a) mostrada na Figura 5.4(d) $($ Raio $=2)$ corresponde às dilatações exatas da forma original, que neste caso é um ponto. Embora seja extremamente simples, este método pode se tornar vagaroso se muitas distâncias forem consideradas. Em tais casos é possível usar o esquema de propagação rápida proposto em [97] a fim de se obterem as 
Tabela 5.1: Estrutura de dados SEDR.

\begin{tabular}{|c|c|c|}
\hline Distância & $N_{o}$ de pontos & Coordenadas \\
\hline 0 & 1 & $(0,0)$ \\
\hline 1 & 4 & $(1,0),(0,1),(-1,0),(0,-1)$ \\
\hline$\sqrt{2}$ & 4 & $(1,1),(1,-1),(-1,-1),(-1,1)$ \\
\hline 2 & 4 & $(2,0),(0,2),(-2,0),(0,-2)$ \\
\hline
\end{tabular}

dilatações exatas.

\subsubsection{Diagramas de Voronoi}

Qualquer conjunto de pontos isolados $P_{i}, i=1,2, \ldots, N$, em $R^{2}$ define um respectivo $d i$ agrama de Voronoi de $R^{2}$. Este diagrama corresponde ao particionamento de $R^{2}$ em $N$ regiões, que podemos chamar de $D_{i}$, associadas com cada um dos pontos $P_{i}$, de tal modo que qualquer ponto dentro da região $D_{i}$ está mais próximo do ponto $P_{i}$. Os pontos que são equidistantes a dois ou mais pontos $P_{i}$ definem as fronteiras de separação [6]. Como exemplo, a figura 5.5 mostra uma imagem de AFM de POMA, e o respectivo particionamento de Voronoi a partir dos picos localizados.

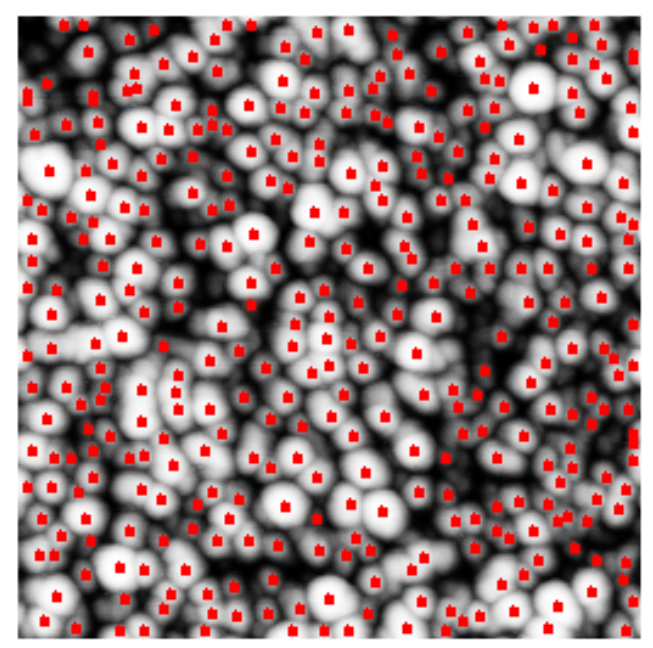

(a)

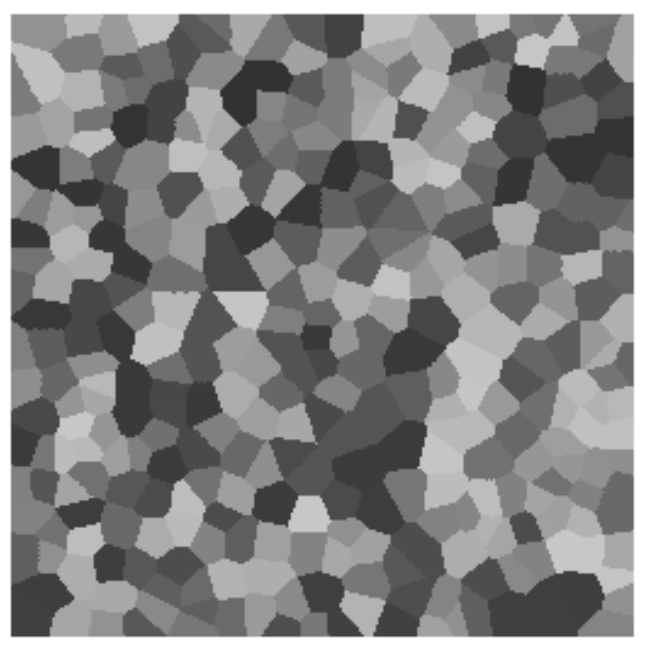

(b)

Figura 5.5: (a) Contagem dos glóbulos. (b) Diagrama de Voronoi. Cada região possui um tom de cinza diferente. Varredura: $2 \times 2 \mu \mathrm{m}^{2}$.

O diagrama de Voronoi fornece um meio eficiente de se particionar o espaço $R^{2}$ no sentido de que cada região $D_{i}$ pode ser entendida como uma região de influência do ponto $P_{i}$. 
O conceito do diagrama de Voronoi pode ser generalizado para um conjunto de formas isoladas, ao invés de pontos. Neste caso temos o diagrama generalizado de Voronoi, conforme ilustrado na figura 5.6.

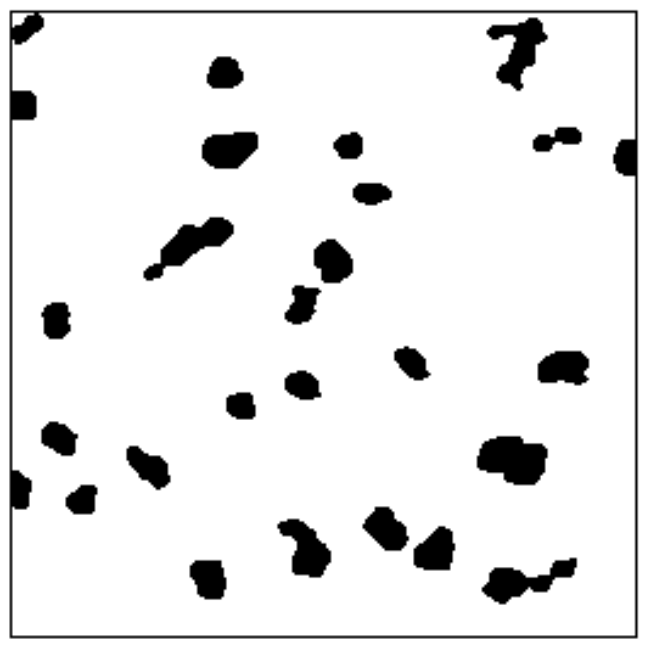

(a)

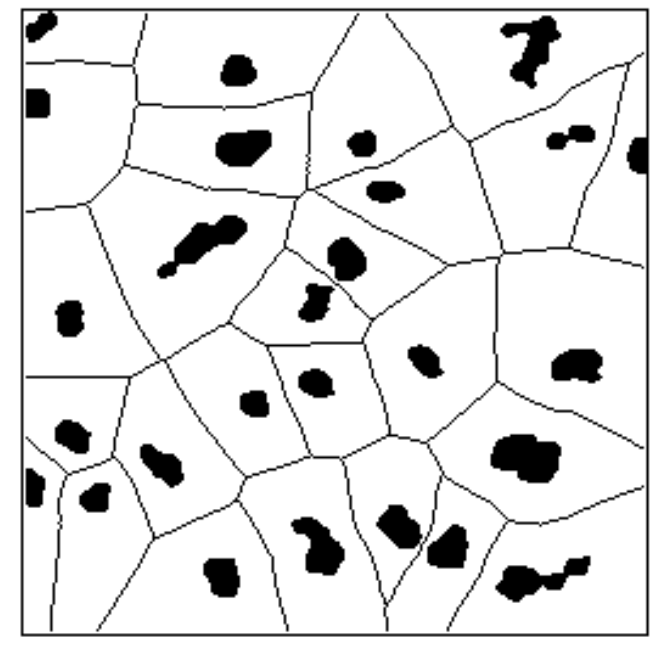

(b)

Figura 5.6: (a) Uma imagem contendo vários objetos conexos. (b) Diagrama generalizado de Voronoi.

Embora uma série de algoritmos eficientes para o cálculo dos diagramas de Voronoi tenha sido publicada na literatura [98], estes algoritmos são relativamente complexos. No nosso caso, foi aplicado o algoritmo das dilatações exatas [6]. Isto é possível por se rotular cada um dos pixels adjacentes aos picos com um valor sucessivo inteiro, propagando esses rótulos durante a dilatação exata. No fim deste processo uma representação do diagrama de Voronoi é obtido. Na figura 5.5 observamos a imagem e seu respectivo diagrama de Voronoi, sendo que cada região está representada por um tom de cinza diferente, relacionado ao número inteiro propagado. A partir deste diagrama temos uma aproximação das regiões dos glóbulos. Estas regiões podem ser facilmente reconhecidas pois cada uma possui um tom de cinza distinto. O diagrama é percorrido e a área de cada região é calculada contando-se a quantidade de pixels em cada uma. Esta área é atribuída a um círculo e o respectivo raio é calculado para cada região. Todos estes raios são calculados e guardados numa lista e depois mostrados num histograma que permite a identificação do intervalo de raios predominantes na amostra. 
A figura 5.7 mostra a imagem da figura 5.1 superposto ao seu respectivo diagrama de Voronoi. Pode-se observar que o particionamento corresponde razoavelmente à região dos domínios convexos. As regiões que não corresponderem aos glóbulos podem ser eliminadas através de um recurso do software SPIA e seu raio não será contado. O critério de escolha é baseado na inspeção visual.

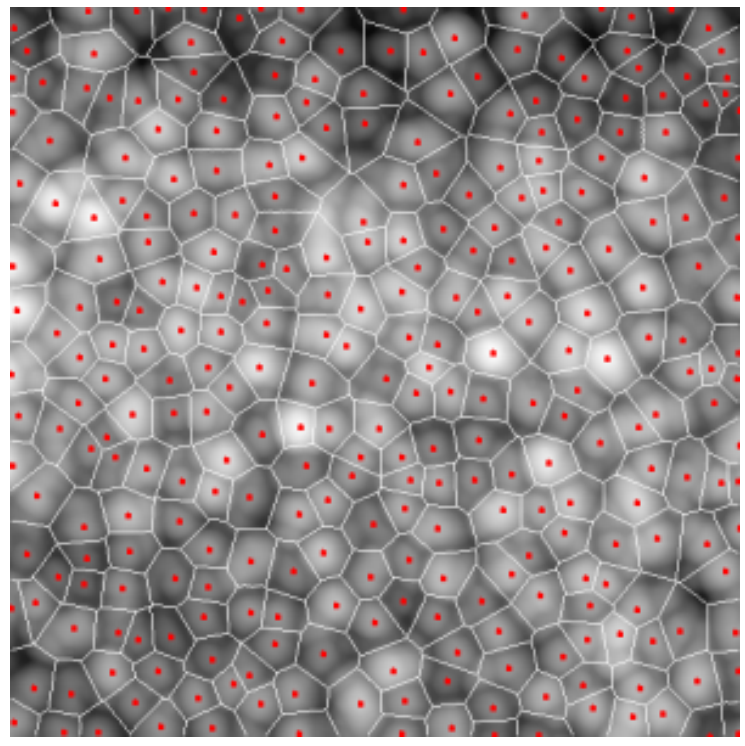

Figura 5.7: Superposição da imagem original de POMA e seu respectivo diagrama de Voronoi.

\subsection{Aplicações}

A título de ilustração, serão empregados os métodos abordados na seção anterior para caracterizar estatisticamente propriedades importantes em filmes LBL de POMA alternados com PVS, que dependem das condições de fabricação. Iremos nos concentrar nos efeitos da concentração da solução, que afetam a morfologia do filme consideravelmente. O procedimento para a fabricação do filme é descrito em [84, 99]. A POMA foi sintetizada quimicamente de acordo com a rota descrita em [100], em que a massa molar média esperada é de aproximadamente $30.000 \mathrm{~g} / \mathrm{mol}$, com uma polidispersividade de 4. As soluções de POMA foram preparadas dissolvendo-se o polímero em água deionizada fornecida pelo sistema de purificação Milli-Q. A solução original foi preparada com 1,202g de POMA em $20 m L$ de acetonitrila e $980 m L$ de água, para uma concentração de POMA de $0.6 g / L$. Soluções mais 
diluídas de 0,3 e $0,03 g / L$ foram preparadas a partir de diluições com água deionizada da solução original. $\mathrm{O}$ pH de todas as soluções foi ajustado para 3 com solução aquosa de $\mathrm{HCl}$ 1 M. A morfologia do filme foi investigada usando o microscópio Nanoscope III (Digital Instruments) no modo intermitente para obtenção de imagens de $512 \times 512$ pixels.

A figura 5.8 mostra as imagens tridimensionais de filmes LBL obtidos com POMA nas concentrações de $0.03 \mathrm{~g} / \mathrm{L}$, (b) $0.3 \mathrm{~g} / \mathrm{L}$ e (c) $0.6 \mathrm{~g} / \mathrm{L}$, com uma janela de varredura de $500 \times 500 \mathrm{~nm}^{2}$. A figura 5.9 mostra à esquerda as imagens de altura dos filmes LBL POMA/PVS, o perfil em determinada linha de varredura e à direita, histogramas com a distribuição dos raios dos agregados. O número e o raio dos glóbulos foram determinados de acordo com a metodologia descrita na seção anterior [103]. O aumento da concentração faz com que diminua o número dos glóbulos mas aumente o raio médio e sua dispersão. O raio aumenta em um fator de 4, o que leva a um aumento de 16 vezes na área ocupada por cada domínio. Isto explica a diminuição por um fator de aproximadamente 20 no número de glóbulos, considerando que a área total é fixa. A tabela 5.2 resume as informações quantitativas obtidas usando os métodos apresentados neste capítulo.

Os resultados mostram que o tamanho dos glóbulos se torna mais disperso à medida que aumenta a concentração, enquanto que o centro da distribuição é deslocado para um raio maior. Para filmes obtidos com a solução S3 (c=0.03 g/L), o tamanho dos glóbulos não varia significativamente, levando a uma baixa rugosidade. Poder-se-ia esperar que a rugosidade média (RMS) aumentasse com a concentração. No entanto a tabela 5.2 mostra que a rugosidade para filmes obtidos com $\mathrm{c}=0.6 \mathrm{~g} / \mathrm{L}$ é mais baixa que para $\mathrm{c}=0.3 \mathrm{~g} / \mathrm{L}$. A razão para este resultado é que a janela de varredura $500 \times 500 \mathrm{~nm}^{2}$ é próxima das dimensões dos glóbulos no filme com maior concentração. Assim, há poucos glóbulos cuja altura varia substancialmente. Uma descrição mais detalhada sobre a aplicação deste método de caracterização pode ser vista em [101], onde se discute a influência da concentração no processo de agregação de glóbulos em filmes LBL. O mesmo método foi aplicado em [102] para a aplicação do modelo de Avrami ao processo de adsorção em filmes LBL POMA/PVS e em [103] no estudo 

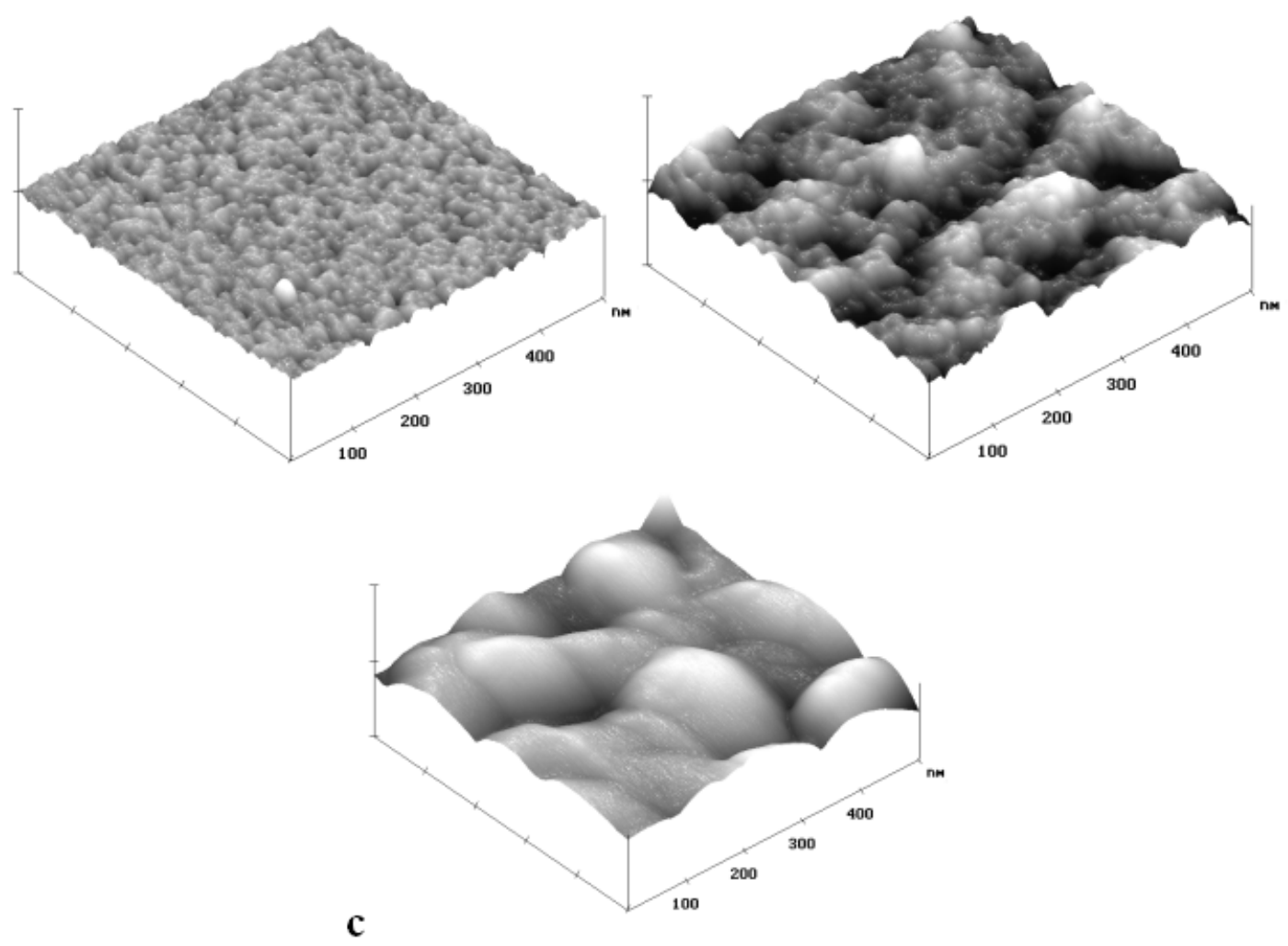

Figura 5.8: Imagens de AFM de filmes LBL com uma camada de POMA adsorvida sobre 10 bicamadas de POMA/PVS, sendo que cada camada foi adsorvida com um tempo de 3 min. O tempo de adsorção para a $11^{a}$ camada de POMA foi de $30 \mathrm{~min}$. A concentração da solução foi (a) $0.03 \mathrm{~g} / \mathrm{L}$, (b) $0.3 \mathrm{~g} / \mathrm{L} \mathrm{e} \mathrm{(c)} 0.6 \mathrm{~g} / \mathrm{L}$.

do efeito da concentração da solução também em filmes LBL POMA/PVS. 

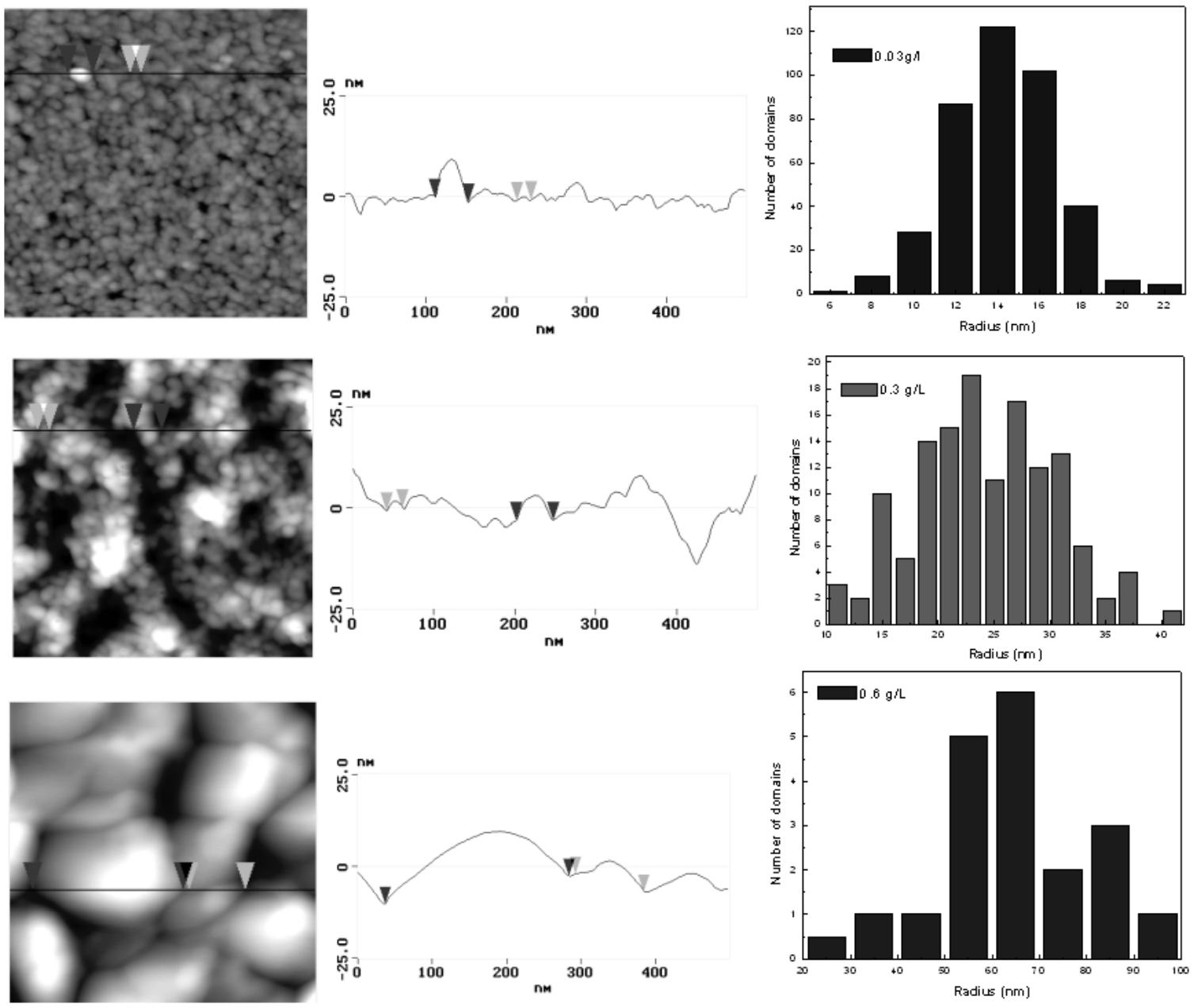

Figura 5.9: Esquerda: Imagens de AFM (500x500 $\left.\mathrm{nm}^{2}\right)$ para filmes POMA/PVS adsorvidos de soluções de POMA com três concentrações: 0.6, 0.3 e $0.03 g / l$. Meio: Perfil transversal das imagens. Direita: Distribuição dos raios dos glóbulos.

\subsection{Conclusão}

Os métodos descritos para contagem de glóbulos e estimativa de raios constituem uma ferramenta útil de razoável precisão para caracterização não só de filmes poliméricos mas de qualquer imagem em que haja domínios aproximadamente convexos. Uma descrição do método pode ser vista em [103]. Os resultados mostraram que ocorreu um aumento de quatro vezes nos raios dos glóbulos com a concentração da solução de POMA, usada na adsorção. Atribuise isso ao aumento da interação polímero-polímero em altas concentrações. Os resultados deste trabalho foram publicados em $[103,102,101]$. 
Tabela 5.2: Análise quantitativa das imagens de AFM. São apresentados o número dos glóbulos, raio máximo, mínimo e médio dos glóbulos, rugosidade RMS, para as três concentrações.

\begin{tabular}{|l|l|l|l|l|l|}
\hline $\begin{array}{l}\text { Concentração } \\
(\mathrm{g} / \mathrm{L})\end{array}$ & $\begin{array}{l}N^{o} \\
\text { glóbulos }\end{array}$ & $\begin{array}{l}\text { Raio mínimo } \\
(\mathrm{nm})\end{array}$ & $\begin{array}{l}\text { Raio } \\
\text { máximo } \\
(\mathrm{nm})\end{array}$ & $\begin{array}{l}\text { Raio médio } \\
(\mathrm{nm})\end{array}$ & $\begin{array}{l}\text { Rugosidade } \\
\text { RMS (nm) }\end{array}$ \\
\hline \hline $0.03(\mathrm{~S} 3)$ & 398 & 5 & 23 & $14 \pm 3$ & 2 \\
\hline $0.3(\mathrm{~S} 2)$ & 134 & 11 & 42 & $24 \pm 6$ & 12 \\
\hline $0.6(\mathrm{~S} 1)$ & 19 & 27 & 91 & $60 \pm 20$ & 8 \\
\hline
\end{tabular}




\section{Capítulo 6}

\section{Análise do aumento de fotoluminescência em filmes PPV}

\subsection{Introdução}

Neste capítulo são utilizados algoritmos apresentados no capítulo anterior, os histogramas de alturas de todos os pixels da imagem e contagem dos picos. Os picos são definidos como os pontos mais claros da imagem, que representam as alturas mais elevadas. Além desses, foram desenvolvidos algoritmos de filtragem através da transformada de Fourier, para seleção ou exclusão de determinadas frequências na imagem e o histograma das distâncias dos picos entre si. Estes algoritmos são utilizados para extração de medidas em imagens de AFM a fim de se estudar o fenômeno do aumento da fotoluminescência em filmes de PPV irradiados por laser. O capítulo apresenta inicialmente uma motivação para o estudo deste fenômeno e em seguida é descrito o aparato experimental envolvido, os algoritmos desenvolvidos, resultados, discussão e a conclusão. Este trabalho foi feito em colaboração com a Prof ${ }^{a}$. Yara G. Gobato da UFSCar, os Profs. Alexandre Marletta da Universidade Federal de Uberlândia, Roberto M. Faria, Cléber R. Mendonça e a pesquisadora Letícia Vega do Instituto de Física da USP de São Carlos. 


\subsection{Aumento da luminescência em filmes PPV}

O desenvolvimento recente dos estudos de superfícies através do AFM tem sido estimulado como consequência do interesse em aplicações tecnológicas de semicondutores orgânicos em dispositivos usando-se diodos emissores de luz poliméricos. O problema fundamental é a correlação entre a topologia da superfície e as propriedades óptico-eletrônica dos filmes poliméricos. A análise de superfícies de polímeros emissores de luz tem sido explorada extensivamente através do AFM [104, 105], sendo que este procedimento possui a vantagem de proporcionar uma alta resolução espacial e de exercer forças muito baixas sobre a superfície da amostra [2]. No caso de polímeros conjugados, a emissão de luz foi possível após considerável progresso na rota de síntese química e no processamento de polímeros solúveis, baseados principalmente em poli(p-fenileno vinileno), PPV e seus derivados [106]. Entretanto, ainda restam grandes dificuldades tecnológicas na produção de filmes finos com boa homogeneidade e estabilidade química. Mais recentemente foram estudadas as alterações químicas e físicas na superfície dos filmes e interpretados como um fator limitante em aplicações tecnológicas destes semicondutores orgânicos [107]. O efeito principal é a degradação do polímero via processo foto-oxidativo durante a fabricação dos filmes na presença de atmosfera agressiva. Este processo oxidativo introduz defeitos estruturais (grupos carbonila) ao longo da cadeia principal do polímero reduzindo o comprimento das conjugações efetivas e agindo como um eficiente canal não radiativo [108, 109]. Recentemente foi demonstrado um efeito oposto com um aumento considerável na fotoluminescência (300\%) usando o processo foto-oxidativo em filmes finos de PPV [111, 112]. O modelo qualitativo para explicar este efeito é baseado na formação de um perfil de degradação da interface ar/polímero para o volume (bulk) durante a foto-irradiação do filme no ar. Portanto, os efeitos de superfície não são conhecidos e podem representar um fator limitante para o uso deste procedimento a fim de se obter materiais opticamente modificados. Neste capítulo serão estudados os efeitos físicos da reação de foto-oxidação sobre filmes PPV através de imagens de AFM e o software SPIA para análise estatística das pro- 
priedades das superfícies. Os resultados mostram uma pequena diminuição da rugosidade média, passando de 4 (região não irradiada) para 2.9nm (região irradiada). Observou-se também um aumento significativo $(\sim 10$ vezes $)$ da quantidade de picos acompanhados por um deslocamento da altura média dos pixels da imagem, de 12.85 para $6.68 \mathrm{~nm}$ da região não irradiada para a irradiada, respectivamente. Através do processo de foto-oxidação e uma técnica holográfica foi produzida uma grade de difração de período de $1.41 \mu \mathrm{m}$ na superfície do PPV sendo que isso foi confirmado pelas medidas feitas na imagem de AFM. A pequena diferença em altura pico-vale da grade indica que o aumento da fotoluminescência (PL) é um efeito essencialmente de volume (bulk) devido a variações no índice de refração e não de superfície.

\subsection{Parte experimental}

\subsubsection{Preparação do substrato}

O polímero precursor do PPV padrão, poli(cloreto de xilideno tetrahidrotiofeno), (PTHT), foi sintetizado seguindo a rota descrita em [113]. Os filmes PTHT foram depositados em substratos hidrofóbicos e mantidos sob vácuo $\left(10^{-2} \mathrm{~atm}\right)$ por 12 horas a fim de se remover o solvente. Estes filmes foram convertidos em filmes de PPV através de uma conversão térmica a $230^{0} \mathrm{C}$ por duas horas sob vácuo a $10^{-2} \mathrm{~atm}$. A espessura final do filme PPV foi de $0,9 \mu \mathrm{m}$. A irradiação dos filmes PPV foi realizada sob condições atmosféricas usando-se um laser de íon de argônio $\left(A r^{+}\right)$operando em $458 \mathrm{~nm}$ com baixa irradiância $\left(200 \mathrm{~mW} / \mathrm{cm}^{2}\right)$. O sinal PL foi gravado por um espectrômetro Spex 500M e detectado por um sistema fotocontador conectado a um fotomultiplicador Hamamatsu R518.

As imagens de AFM foram produzidas com o Nanoscope IIIa Multimode da Digital Instruments no modo tapping. A área escaneada foi de $10 \times 10 \mu m^{2}$ a uma taxa de $0.7 \mathrm{~Hz}$.

\subsubsection{Obtenção da grade}

O aparato experimental para a obtenção da grade é mostrado na figura 6.1. 


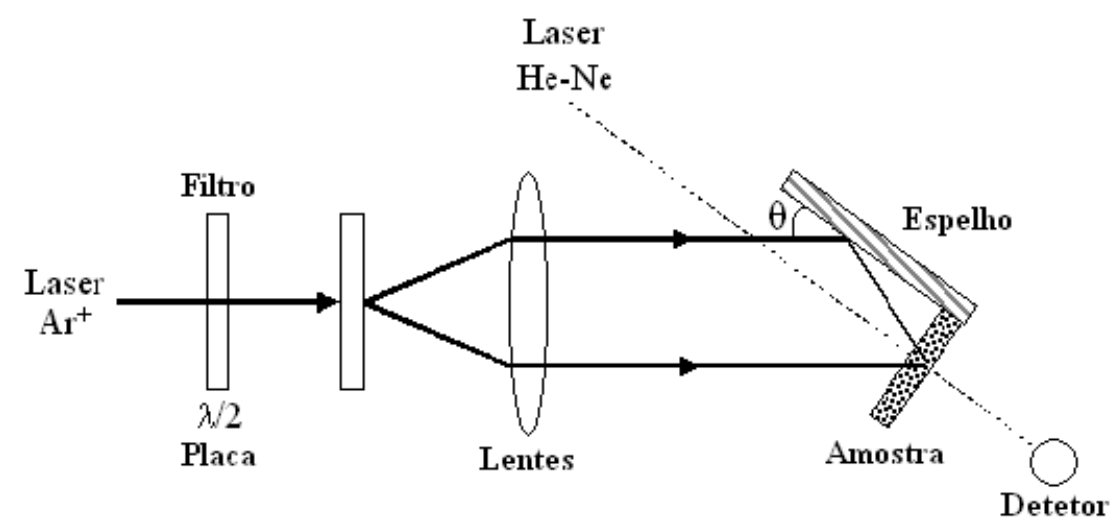

Figura 6.1: Aparato experimental para a obtenção da grade.

O espelho de Lloyd é usado para produzir um padrão de interferência $[115,116]$. Um laser de argônio polarizado linearmente operando em $\lambda=488 \mathrm{~nm}$ foi usado para produzir a grade. Este feixe de laser passa através de uma placa de meia onda para controlar sua polarização e é expandido e colimado antes de irradiar a amostra. Metade do feixe colimado atinge diretamente a amostra enquanto que a outra parte é refletida na amostra através do espelho. O ângulo incidente do feixe foi de $\theta=10^{\circ}$, resultando em um espaçamento da grade de cerca de $1.41 \mu \mathrm{m}$. Um laser de baixa potência, He-Ne, operando em $633 \mathrm{~nm}$ foi usado como feixe de prova para medir a eficiência da difração da grade, permitindo o monitoramento do processo de formação.

\subsection{Análise das imagens}

A análise e o processamento das imagens foram feitas através do software SPIA, desenvolvido especialmente para isso. Inicialmente foi aplicado o filtro da mediana, para a eliminação de ruídos criados no processo da captação da imagem. Este filtro mostrou-se eficiente em remover ruídos impulsivos e riscos provocados pela ponta do cantilever [114]. Outro processamento aplicado foi a equalização da imagem, para aumentar a escala dinâmica dos níveis de cinza e consequentemente produzir um aumento no contraste da imagem. Após este processamento serão apresentados os algoritmos utilizados na análise das imagens. 


\subsubsection{Primeiros vizinhos}

Foi aplicada a função de contagem de picos descrita na seção 5.2. Após a contagem e identificação dos picos, o usuário tem a opção de clicar com o mouse sobre determinado pico e entrar com a quantidade $n$ de primeiros picos vizinhos que deseja localizar. O SPIA fornece uma lista com todas as distâncias entre o pico que foi clicado e seus primeiros $n$ vizinhos.

\subsubsection{Transformada de Fourier 2D}

O teorema de Fourier declara que é possível descrever funções unidimensionais ou bidimensionais como uma soma de uma série de senos, cossenos de frequências crescentes ou funções exponenciais básicas. A transformada de Fourier de uma função 2D $f(x, y)$ é representada por $F(u, v)$ e descreve a quantidade de cada freqüência que deve ser acrescentada para formar $f(x, y)$. A representação da transformada de Fourier direta e inversa constituem um par de equações e para sinais 2D discretos são definidas como sendo [6],

$$
F(u, v)=\frac{1}{N M} \sum_{x=0}^{M-1} \sum_{y=0}^{N-1} f(x, y) e^{\left[-j 2 \pi\left(\frac{u x}{M}+\frac{v y}{N}\right)\right]}
$$

$\mathrm{e}$

$$
f(x, y)=\sum_{u=0}^{M-1} \sum_{v=0}^{N-1} F(u, v) e^{\left[j 2 \pi\left(\frac{x u}{M}+\frac{y v}{N}\right)\right]}
$$

Aplicada em imagens, $f(x, y)$ representa a imagem em tons de cinza ou alturas no caso das imagens produzidas pelo AFM. $M$ é o número de pixels da imagem na direção $x$ e $N$ é o número de pixels da imagem na direção $y$.

Os incrementos de cada função estão relacionados através das expressões: 


$$
\Delta u=\frac{1}{M \Delta x}
$$

$\mathrm{e}$

$$
\Delta v=\frac{1}{N \Delta y}
$$

Esta formulação é conhecida com DFT (discret Fourier transform) e para o caso de imagens de AFM, $M=N$.

\subsubsection{Densidade espectral de potência}

A aplicação da transformada de Fourier em uma imagem resulta em uma imagem das intensidades das freqüências que compõem a imagem original. Para a visualização da transformada, é comum plotar o seu PSD (power spectral density) ou densidade espectral de potência (DEP)[117, 118]. Uma das definições para a DEP é dada por :

$$
P(u, v)=|F(u, v)|^{2}=R^{2}(u, v)+I^{2}(u, v)
$$

A figura 6.2 mostra uma imagem de AFM e sua respectiva DEP com um limiar de 113, a fim de destacar as frequências mais intensas.

Em imagens, as variáveis $x$ e $y$ representam a escala em metros (ou nanômetros) e as variáveis $u$ e $v$ representam o inverso do metro (ou inverso do nanômetro). Os termos de baixa freqüência próximos da origem da DEP são responsáveis pela estrutura geral da imagem ao passo que os componentes de alta freqüência fornecem os contornos da imagem e os detalhes finos. Uma estrutura periódica no domínio espacial da imagem será representada por dois picos na imagem da DEP em um raio relacionado ao período da freqüência correspondente ao atributo da imagem e a direção deste pico em relação à origem corresponde à 

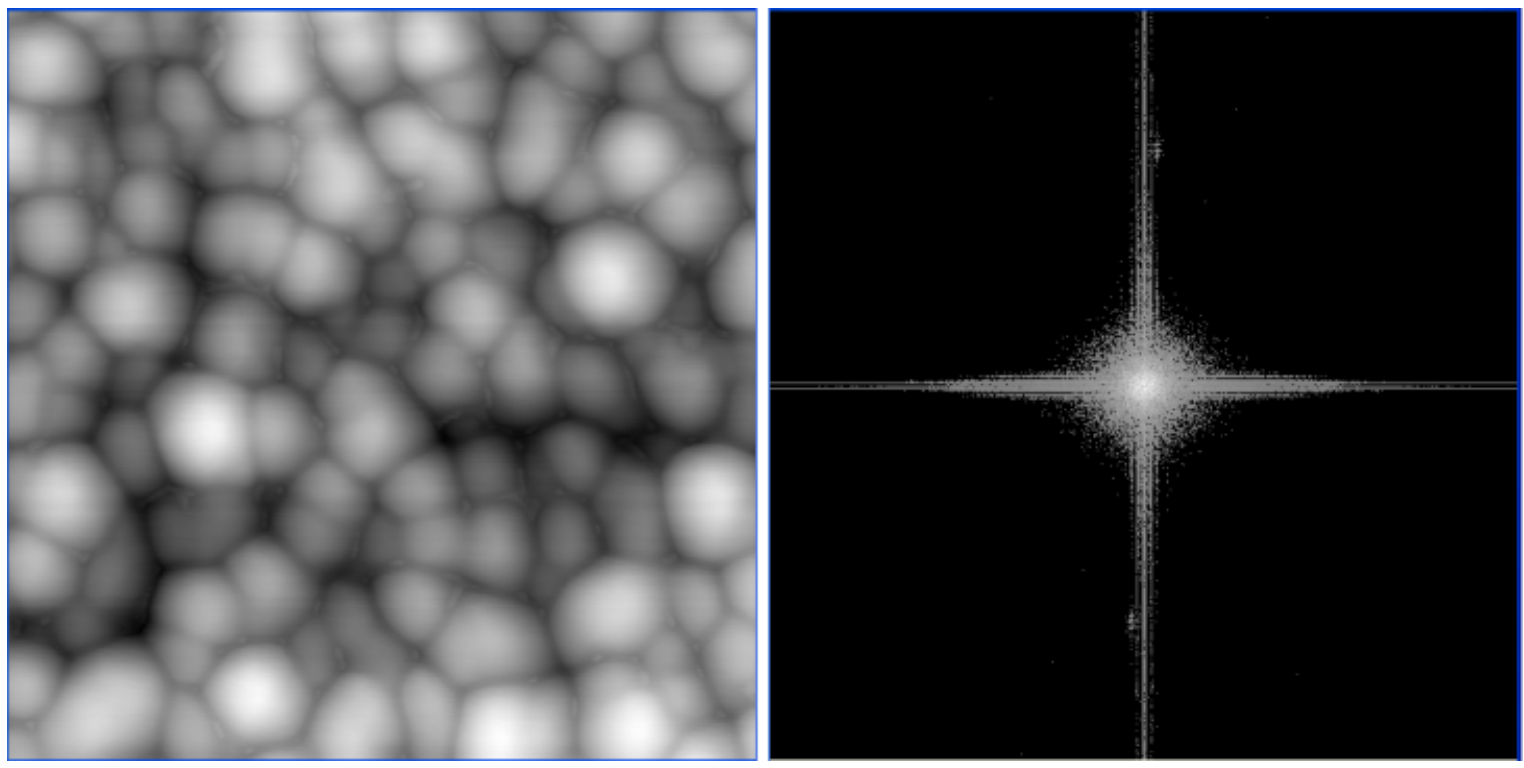

Figura 6.2: Imagem de AFM e sua DEP. Varredura: 500x500 $\mu \mathrm{m}^{2}$.

orientação deste atributo. A seleção de determinadas frequências no espaço da DEP e sua transformada inversa permitirá a filtragem e visualização de estruturas periódicas contidas na imagem.

\subsubsection{Filtragem por Fourier}

A filtragem por Fourier permite que se possa selecionar estruturas periódicas a fim de se estudar suas propriedades. Esta filtragem pode ser realizada no domínio da frequência multiplicando-se a transformada de Fourier do sinal a ser analisado por uma função de filtro e fazer a transformada inversa $\left(\digamma^{-1}\right)$ deste resultado. Isto significa que se $f(x, y)$ é a função a ser filtrada, $F(u, v)$ é sua respectiva transformada de Fourier e $V(u, v)$ é a função de filtro, o sinal filtrado de $f(x, y)$ será representado por $g(x, y)$ e será obtido por [6],

$$
g(x, y)=\digamma^{-1}\{F(u, v) V(u, v)\}
$$

Esta operação equivale a convolução da função $f(x, y)$ com a transformada inversa de Fourier $v(x, y)$ da função filtrante $V(u, v)$ [6]. Para ilustrar este procedimento, considere a imagem de AFM na figura 6.2 e sua DEP. No software SPIA o usuário pode estabelecer um 
filtro por selecionar um intervalo de freqüências através de uma máscara circular (função filtrante) de raio variável, conforme figura 6.3.
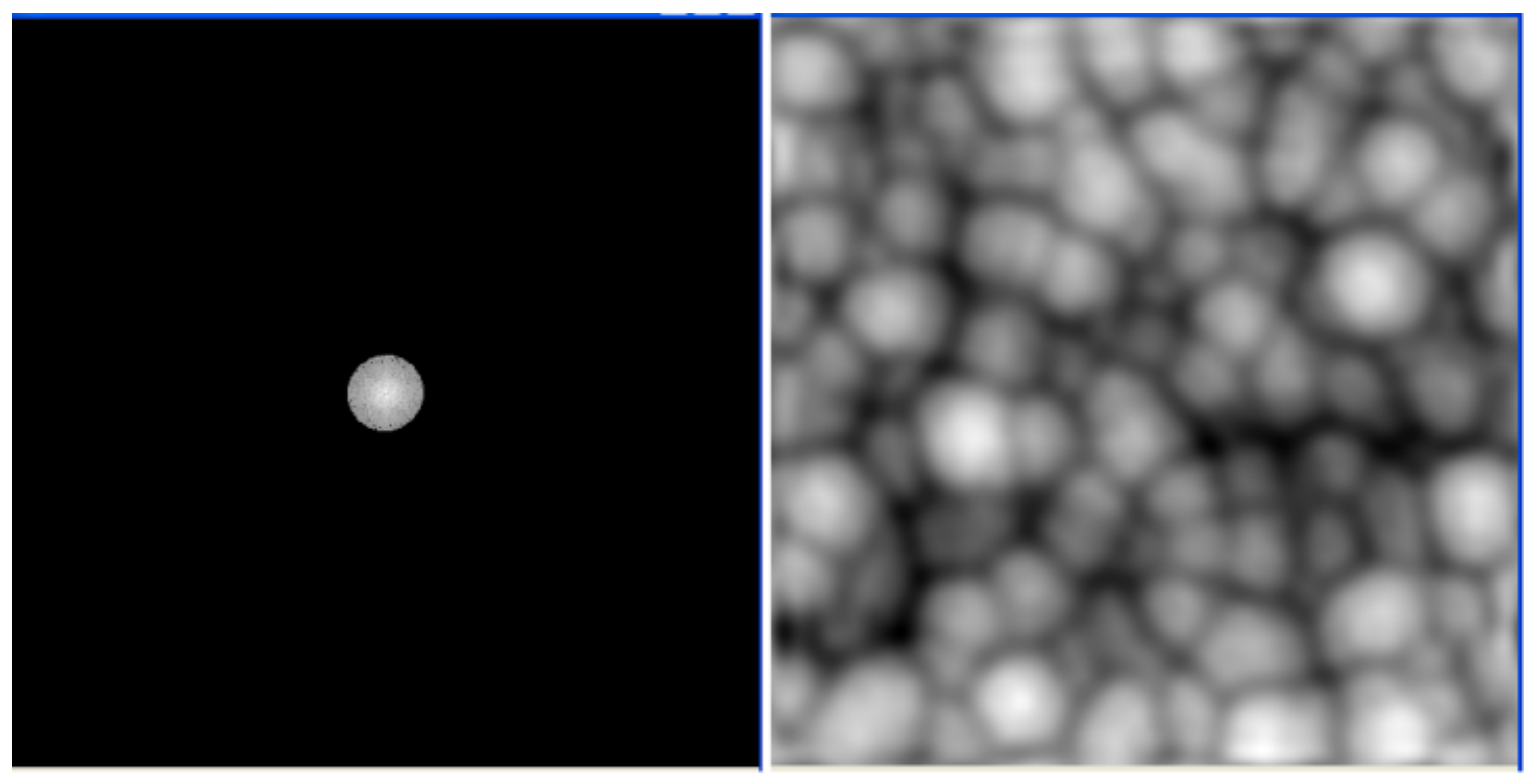

Figura 6.3: Baixas frequências da DEP selecionadas e sua transformada inversa.

O software que acompanha o sistema do AFM fornecido pela Digital Instruments possui uma função semelhante, mas usa uma máscara quadrada. Esta máscara tem-se mostrado ineficiente por não se realizar uma boa seleção de frequências e favorecer determinadas orientações inexistentes, resultando em informações enganosas. Filtros circulares tem-se mostrado mais eficientes, introduzirem menos ruído [110]. Neste caso, foram selecionadas as baixas frequências e as freqüências restantes foram eliminadas, de tal modo que ao se aplicar a transformada inversa de Fourier a imagem final conterá somente a informação referente às baixas freqüências. A figura 6.3 mostra o resultado após a filtragem. Observa-se a forma geral da imagem, mas sem os detalhes de contorno, correspondentes as altas frequências que foram eliminadas. Neste caso, a filtragem corresponde a um filtro passa-baixas. No entanto o usuário tem a opção de colocar a máscara circular em qualquer parte da imagem da DEP e escolher o raio apropriado, selecionando um intervalo maior ou menor de frequências a serem capturadas.

Outra opção para o usuário é a de escolher através da máscara circular o intervalo de freqüências que serão eliminadas, ou seja, o processo inverso. Deste modo, ao se fazer a 
transformada inversa, as informações referentes àquelas freqüências serão eliminadas. Um exemplo dessa opção pode ser vista na figura 6.4.
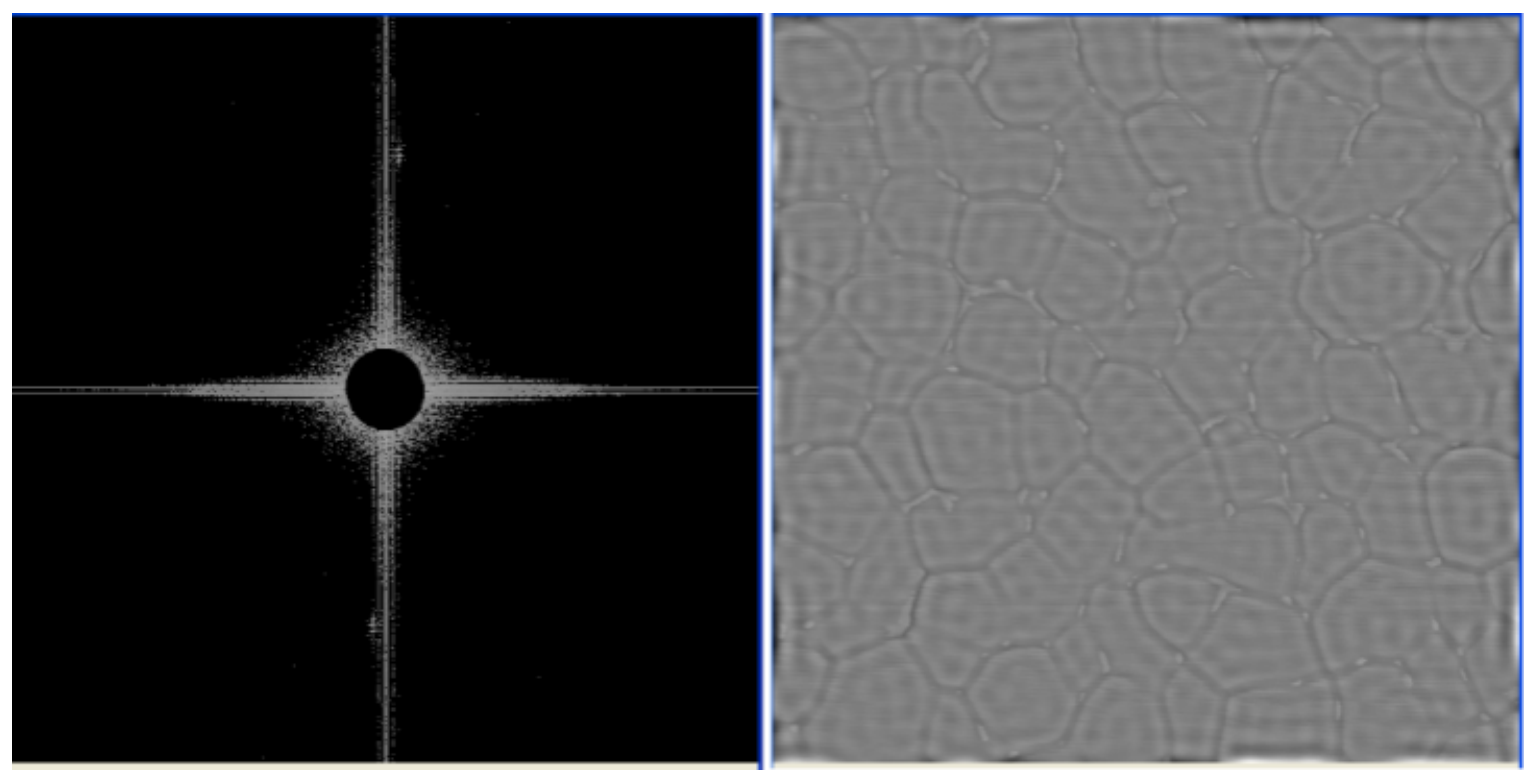

Figura 6.4: Eliminação das baixas frequências, filtro passa alta.

Pode-se observar que foram mantidas somente as altas frequências, responsáveis pelos contornos dos objetos na imagem.

Através desse processo de filtragem por máscara de raio variável, qualquer estrutura periódica contida na imagem da DEP pode ser eliminada ou selecionada. Também este processo pode ser usado para implementar os filtros comuns de passa-altas ou passa-baixas, para detecção ou eliminação de bordas, conforme exemplificados nas figuras 6.3 e 6.4.

\subsection{Resultados e discussão}

As modificações macroscópicas na superfície do PPV foram examinadas através de imagens do microscópio óptico. A figura 6.5 mostra as regiões irradiadas (I) e não irradiadas (NI), claramente distintas e que foram obtidas através de uma câmara CCD acoplada ao microscópio. Observa-se que a maior parte da luz foi transmitida na região irradiada (I), de acordo com o espectro de absorção [112]. Nesta escala macroscópica, a imagem mostra qualitativamente uma baixa não homogeneidade em ambas regiões da superfície, com defeitos morfológicos 
(áreas claras) distribuídos aleatoriamente sobre a superfície. Estes defeitos morfológicos na região NI foram produzidos durante o processo de conversão térmica.

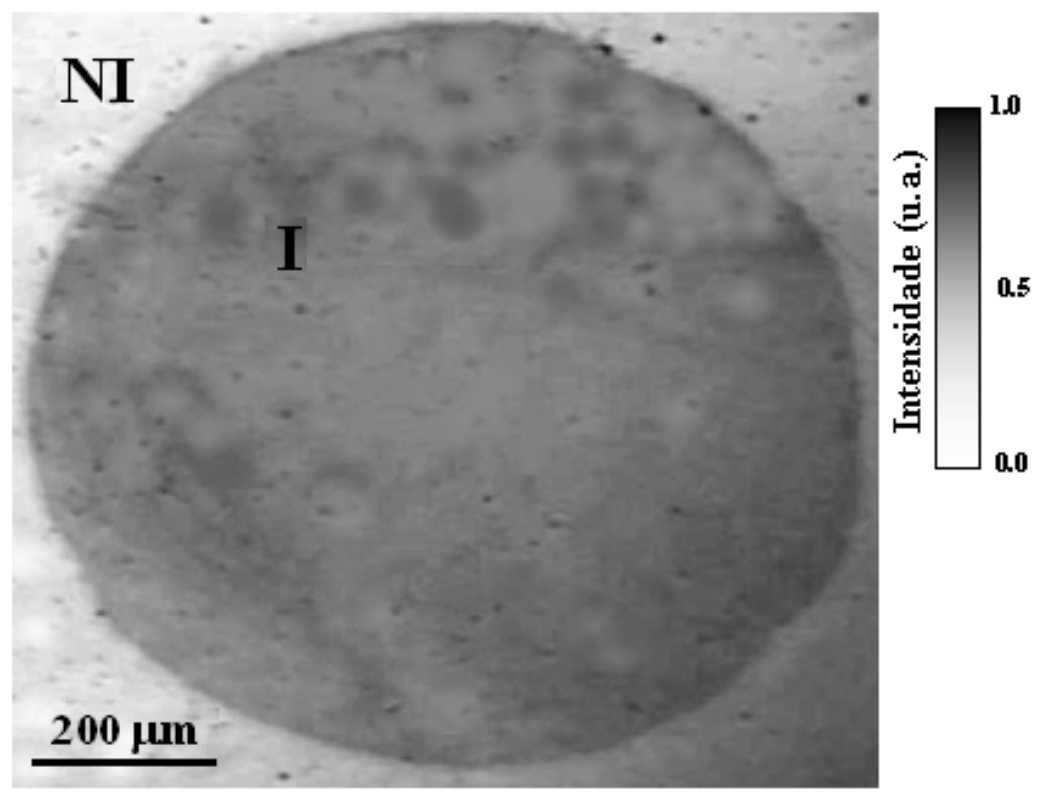

Figura 6.5: Imagem óptica da região irradiada (I) e não irradiada (NI).

A figura 6.6 mostra os espectros de PL do filme PPV antes (0 min.) e depois (35 min.) da exposição ao laser de argônio (458nm) em $200 \mathrm{~mW} / \mathrm{cm}^{2}$ sob condições atmosféricas.

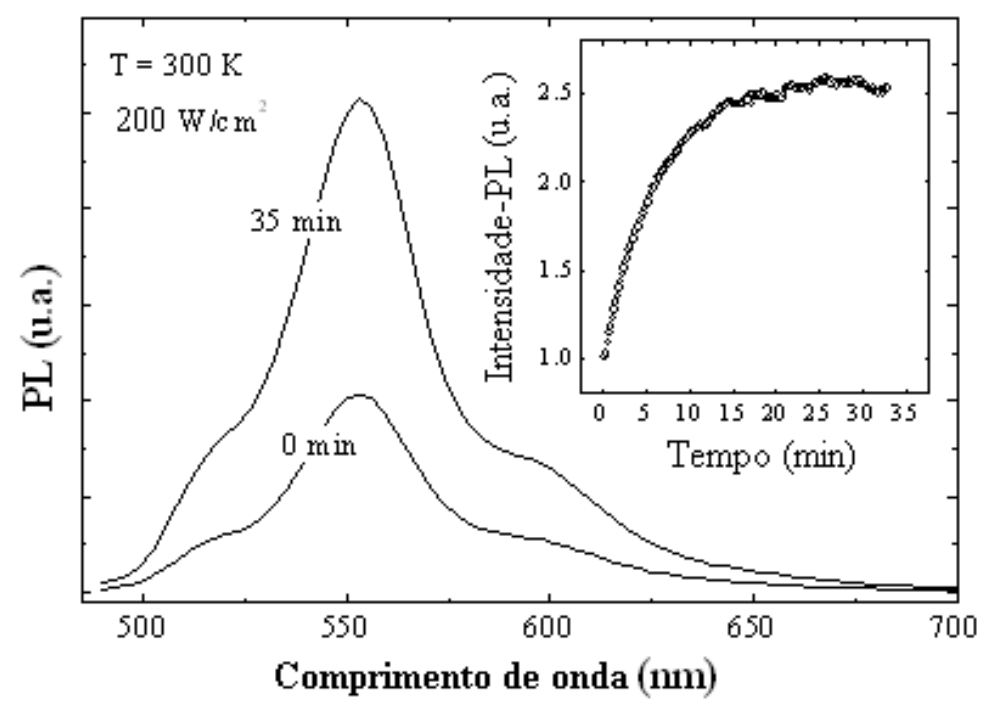

Figura 6.6: Espectros de PL $(300 \mathrm{~K})$, antes $(0 \mathrm{~min}$.) e depois $(35 \mathrm{~min}$. $)$ da exposição à radiação de um filme PPV sob condições atmosféricas, em unidades aleatórias.

Os espectros apresentam a mesma forma e posição do pico de zero-fônon em $516 \mathrm{~nm}$ $(2.4 \mathrm{eV})$. Durante o tempo de exposição de 35 min., a razão entre o pico de zero-fônon e sua 
primeira réplica em $553 \mathrm{~nm}$ permanece constante e igual 0.29 (parâmetro Huang-Rhys S). Este valor indica um alto acoplamento elétron-fônon característico de filmes estruturalmente desordenados. No detalhe desta figura observa-se a dependência da intensidade integrada dos espectros de PL em função do tempo de exposição à excitação luminosa, mostrando que a intensidade relativa de emissão aumenta $150 \%$ atingindo uma saturação com um tempo de 30 min. As evidências da foto-degradação são observadas pelos espectros de absorvância no intervalo do UV-Vis e infravermelho (IR) de acordo com medidas publicadas em [111]. Após a exposição à luz, o espectro de absorção é deslocado para o azul e o espectro de IR apresenta um aumento maior no pico $1690 \mathrm{~cm}^{-1}$, identificado como a incorporação do grupo carbonila $(\mathrm{C}=\mathrm{O})[119,120,121]$.

A figura 6.7 mostra as imagens de AFM obtidas no modo tapping para a região irradiada e não irradiada, indicada como NI e I na figura 6.5.
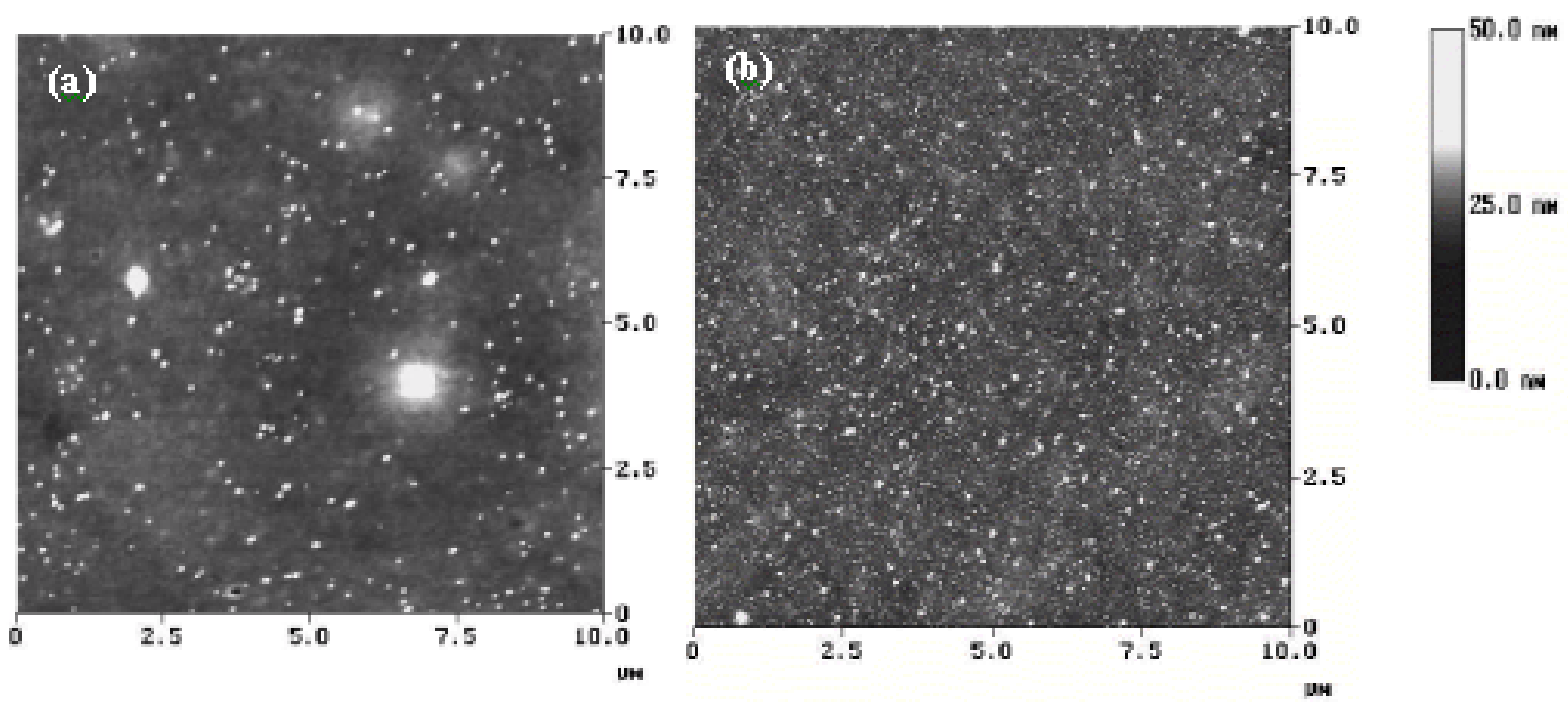

Figura 6.7: Imagem de AFM no modo tapping das regiões não irradiada (a) e irradiada (b). Os dois glóbulos na região não irradiada são defeitos gerados no processo de conversão térmica para a obtenção do PPV. Varredura: 10x10 $\mu \mathrm{m}^{2}$.

Uma simples análise visual destas imagens mostra uma diferença significante entre essas regiões. A região não irradiada mostra um número menor de picos com alturas maiores que $25 \mathrm{~nm}$ (veja a escala de altura da figura ) distribuídos randômicamente sobre a superfície. A região irradiada apresenta um aumento considerável no número de picos, com alturas mai- 
ores que $25 \mathrm{~nm}$ distribuídas mais homogeneamente sobre a superfície. A rugosidade RMS para a região NI é $4 \mathrm{~nm}$ e para a região I é de $2.9 \mathrm{~nm}$. Estes dados incluem alterações induzidas na superfície durante a exposição do filme PPV ao laser mas não são suficientes para se concluir que a superfície I é mais homogênea que a região não irradiada. A análise visual da superfície de filmes poliméricos é de caráter apenas qualitativo carecendo de medidas reais que descrevam quantitativamente as propriedades da superfície. A medida de rugosidade é limitada porque diferentes superfícies podem ter a mesma rugosidade, sendo apenas um número para descrever a imagem inteira. Fica evidente a necessidade de outras medidas que possam descrever de forma particular cada imagem que está sendo analisada.

A metodologia utilizada neste capítulo descreve quantitativamente as imagens de AFM através de um estudo estatístico da distribuição de todas as alturas na imagem e das distâncias entre os picos. A primeira observação é um aumento substancial no número total de picos, sendo que a região irradiada apresenta aproximadamente 5 vezes mais picos (16151) do que a não irradiada (3209), para 150 cortes. A figura 6.8 mostra a distribuição das alturas da região não irradiada e irradiada. A altura zero é atribuida à menor altura de todas e se torna o referencial para as outras.

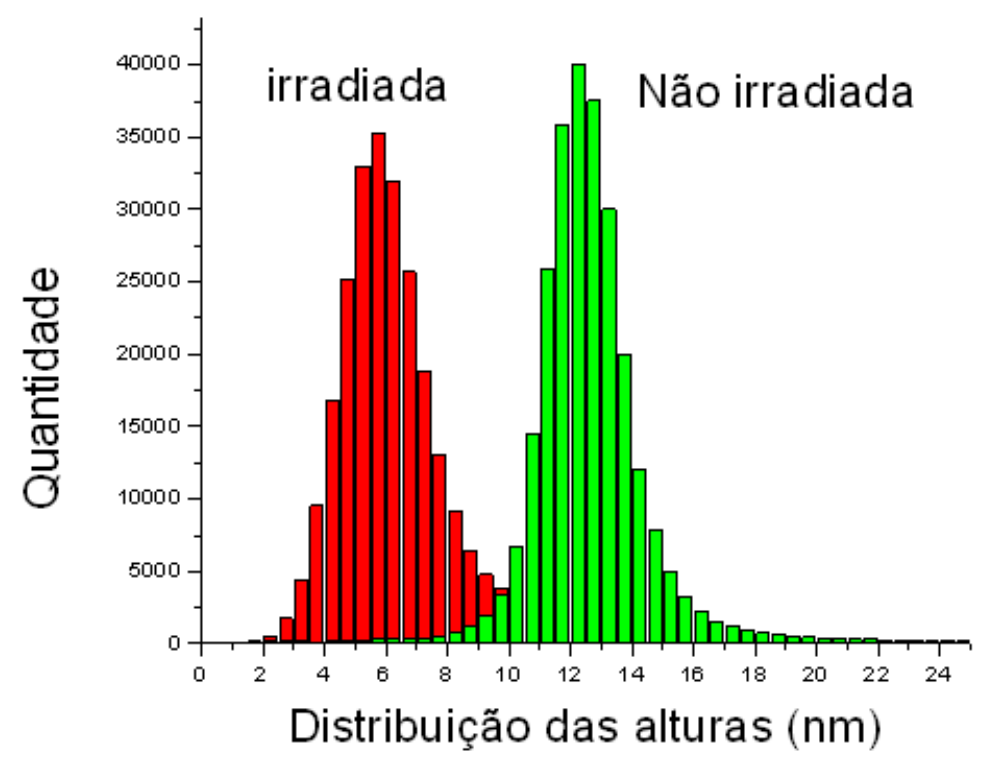

Figura 6.8: Distribuição das alturas de todos os pixels da imagem ( $512 \times 512$ alturas, em cada caso). 
Em ambas regiões, a contribuição maior está no intervalo entre 2.5 e $17 \mathrm{~nm}$. Para estes dados iniciais, podemos observar que a fração de pixels que excedem as alturas de $17 \mathrm{~nm}$ e $20 \mathrm{~nm}$ nas regiões I e NI respectivamente constituem apenas $1 \%$ do número total de alturas em cada caso. A largura da distribuição é estreita, sendo $2.4 \mathrm{~nm}$ e $2.8 \mathrm{~nm}$, centralizadas em $12.4 \mathrm{~nm}$ e $5.9 \mathrm{~nm}$ para as regiões NI e I respectivamente. Estes resultados mostram uma pequena tendência para o aumento da uniformidade da superfície com a diminuição das alturas dos pixels. Comparando-se com a imagem de AFM da figura 6.7, observamos que a contribuição maior para a superfície está centralizada na região com alturas menores $(<$ $17 \mathrm{~nm})$, as quais não são perceptíveis através de inspeção visual.

A figura 6.9 apresenta a distribuição dos picos para as regiões não irradiada e irradiada após 150 cortes. Os histogramas refletem o aumento no número de picos, após a irradiação. Visto que na região não irradiada existem vários aglomerados de tonalidade mais clara, cada um deles é contado como apenas um pico no histograma da figura 6.9 mas contendo várias alturas conforme se observa no histograma da figura 6.8. Isto explica a diferença entre os histogramas das figuras 6.8 e 6.9. Esta diferença favorece a análise proporcionada pelos histogramas de picos, que reflete melhor o efeito da irradiação pelo laser. As larguras dos histogramas foram de $2.2 \mathrm{~nm}$ e $5.0 \mathrm{~nm}$ e centralizadas em $13.3 \mathrm{~nm}$ e $8.9 \mathrm{~nm}$ para as regiões NI e I respectivamente.

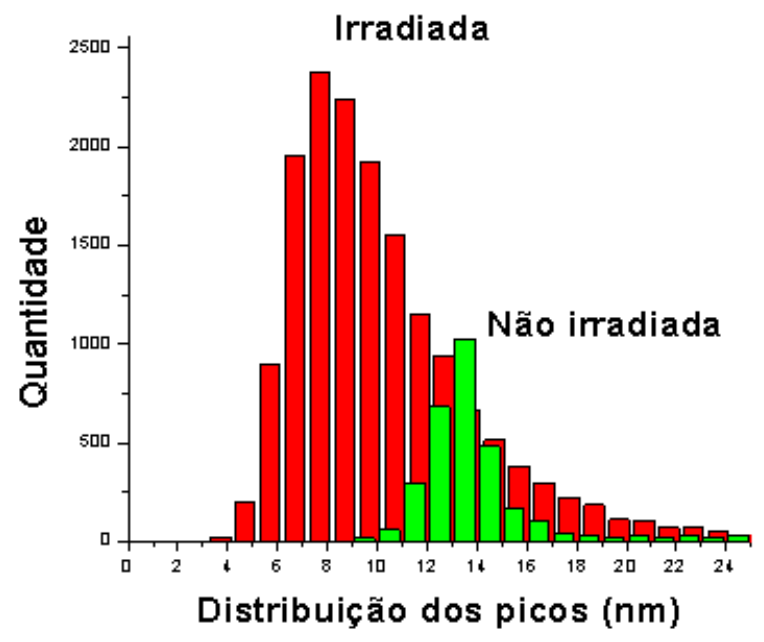

Figura 6.9: Distribuição dos picos contados, após 150 cortes na imagem. Região não irradiada: 3209 picos. Região irradiada: 16151 picos. 
As distribuições das distâncias entre os 100 primeiros picos vizinhos estão plotadas em histogramas na figura 6.10. Estes vizinhos são referentes ao pico localizado na posição $(100,50)$ da imagem.

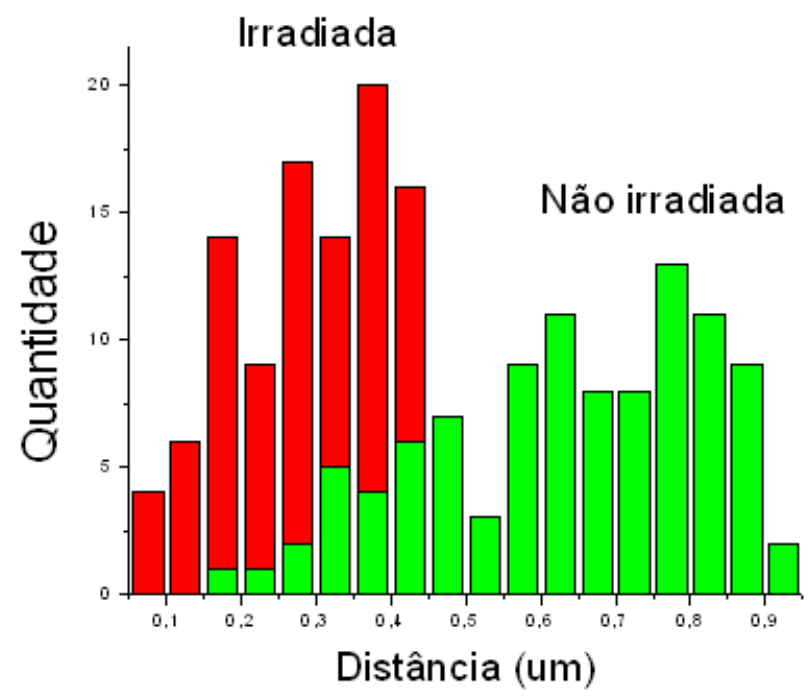

Figura 6.10: Distâncias entre os 100 primeiros picos vizinhos.

Para a região irradiada, o centro da distribuição encontra-se em $0.3 \mu \mathrm{m}$ e para a região não irradiada em $0.6 \mu \mathrm{m}$. As distâncias entre picos na região irradiada são menores visto que a imagem possui uma quantidade maior de picos e por este motivo eles estão mais próximos entre si.

Irradiando-se o filme polimérico de PPV com laser de comprimento de onda $458 \mathrm{~nm}$, observa-se, para tempos relativamente curtos de irradiação, um aumento de sua fotoluminescência. Para tempos muitos longos o efeito é contrário, ou seja, de diminuição da luminescência. Ambos os efeitos, aumento e diminuição estão ligados a estágios distintos de degradação da estrutura por foto-oxidação das cadeias poliméricas. Usando este fenômeno na situação de aumento da fotoluminescência, podemos traçar com o feixe de laser uma grade no filme onde se alternam listras de regiões irradiadas e não irradiadas, usando o aparato experimental já descrito. A figura 6.11(a) mostra a imagem de AFM obtida no modo tapping, e sua imagem equalizada na figura 6.11(b). A escala é de $25.6 \mu \mathrm{m}$. A equalização foi feita para se aumentar a escala dinâmica dos níveis de cinza dos pixels e conseguir um melhor contraste na imagem. Isto também facilita a identificação das frequências na imagem 
da DEP.

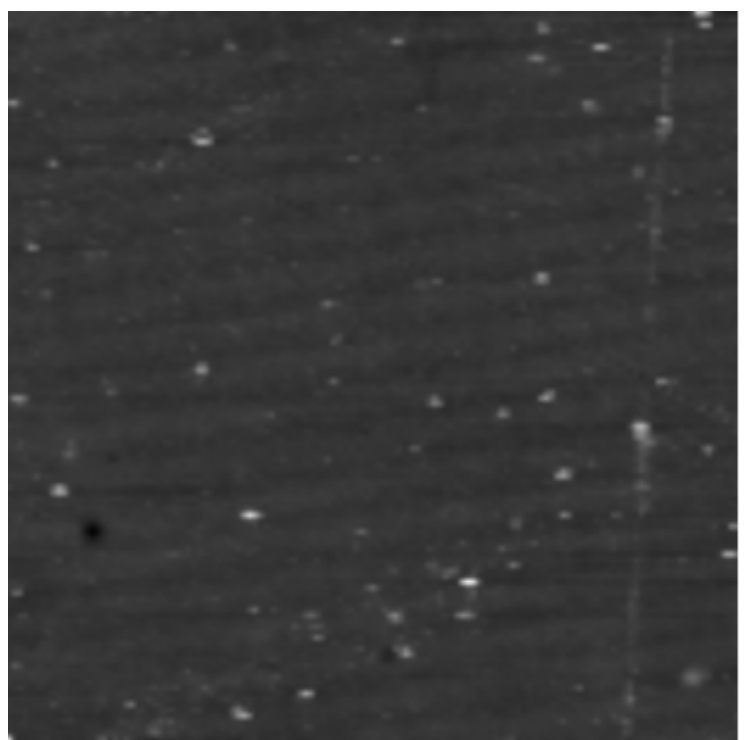

(a)

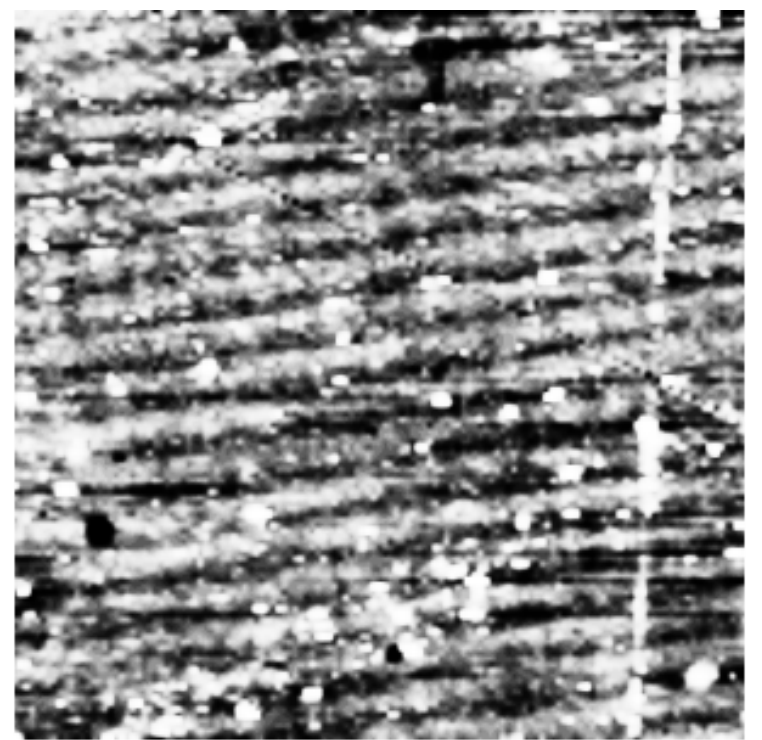

(b)

Figura 6.11: (a) Imagem da grade de difração. (b) A mesma imagem equalizada. Varredura: $25,58 \mu \mathrm{m}^{2}$.

Uma grade similar tem sido observada em filmes azopoliméricos, onde uma força direcionadora que depende do gradiente do campo elétrico e da plasticização local apoiadas pela fotoisomerização trans-cis-trans são os mecanismos responsáveis pela movimentação molecular $[122,123]$. No entanto, no trabalho apresentado neste capítulo, a grade observada na superfície é devida aos canais poliméricos de foto-oxidação que causam alterações na fotoluminescência do PPV, conforme mencionado antes. Esse resultado pode ser de aplicação prática em dispositivos emissores de luz para registrar informações na superfície do material.

A figura 6.12 apresenta a DEP da transformada de Fourier da imagem. São observados dois pontos mais claros, no segundo e quarto quadrantes. Como se pode observar na parte inferior da imagem, o software fornece as informações sobre as frequências em que o mouse aponta (o mouse foi suprimido da imagem). Esses pontos correspondem a uma frequiência de período $1.49 \mu \mathrm{m}$ e orientação de 96.7 graus. Esses dados referem-se a um atributo de periodicidade bem definida na imagem real, provocado pela difração do laser e com esta orientação espacial.

A figura 6.13(a) mostra a seleção destas frequências e a figura 6.13(b) a transformada 


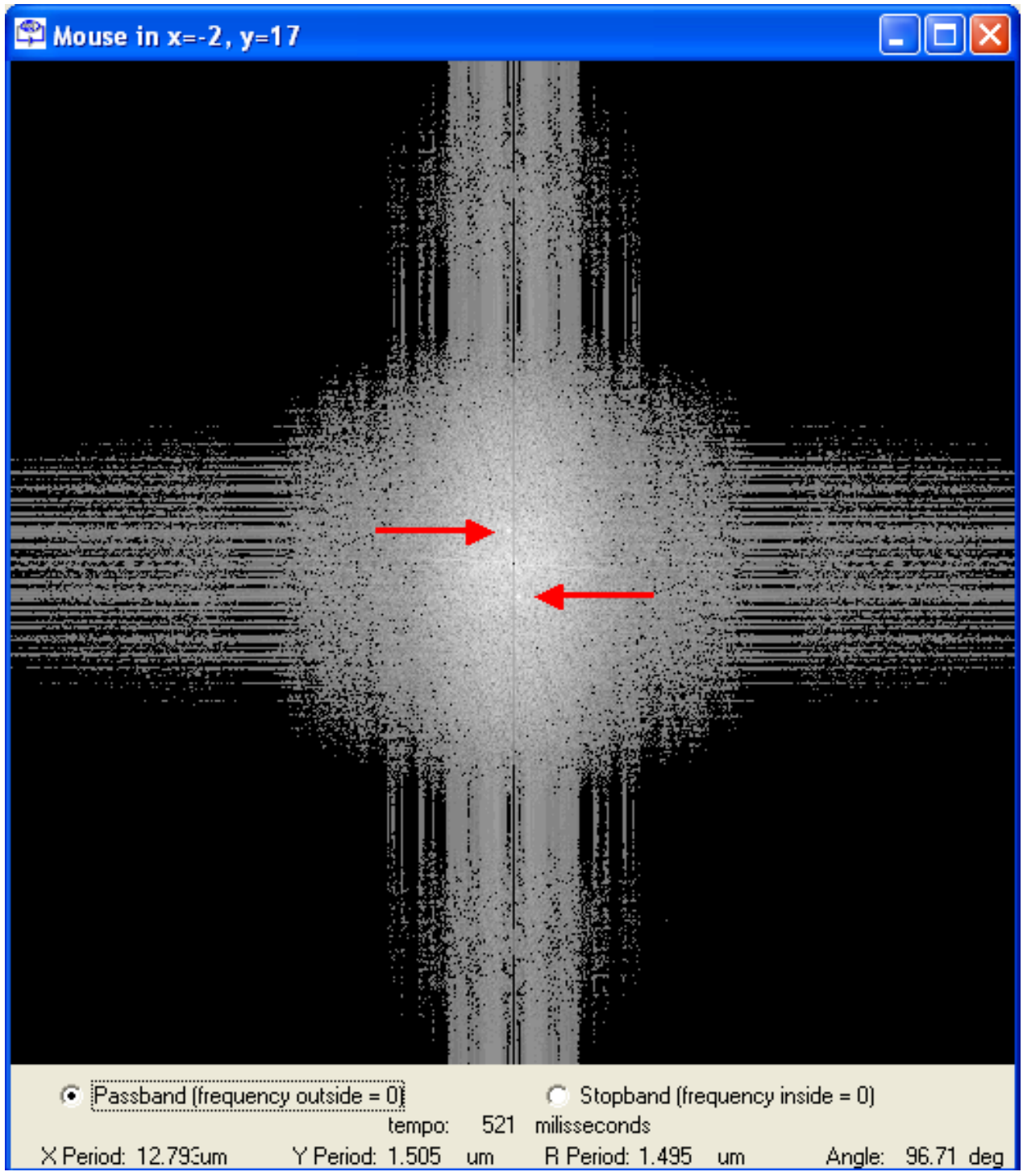

Figura 6.12: Imagem da DEP da grade.

inversa. Observa-se que essas frequiências correspondem a um padrão regular de ondulação na imagem real. A periodicidade desta grade através de análise e processamento das imagens é bastante similar ao obtido através do aparato experimental $(1.41 \mu \mathrm{m})$, evidenciando a confiabilidade dos métodos de análise de imagens.

A figura 6.14 (a) e (b) mostram a seção transversal da imagem original de AFM e a imagem obtida após a filtragem por Fourier. A distância horizontal de um pico a outro pico, na média, para a imagem original é de $1.39 \mu \mathrm{m}$ e $1.51 \mu \mathrm{m}$ para a imagem filtrada.

A diferença em altura pico-vale da grade inscrita na superfície do filme através do processo de foto-oxidação determinado através da seção transversal da imagem original, figura 


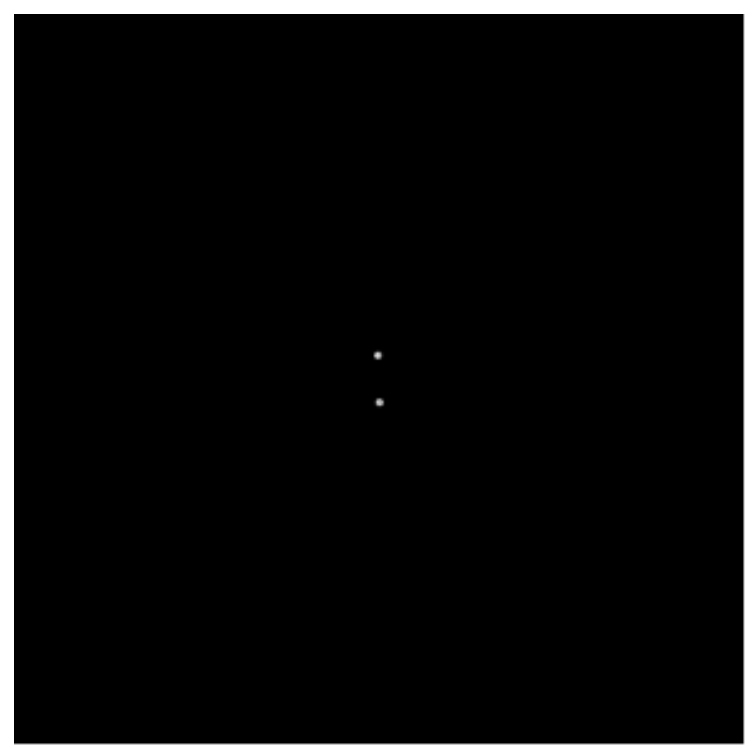

(a)

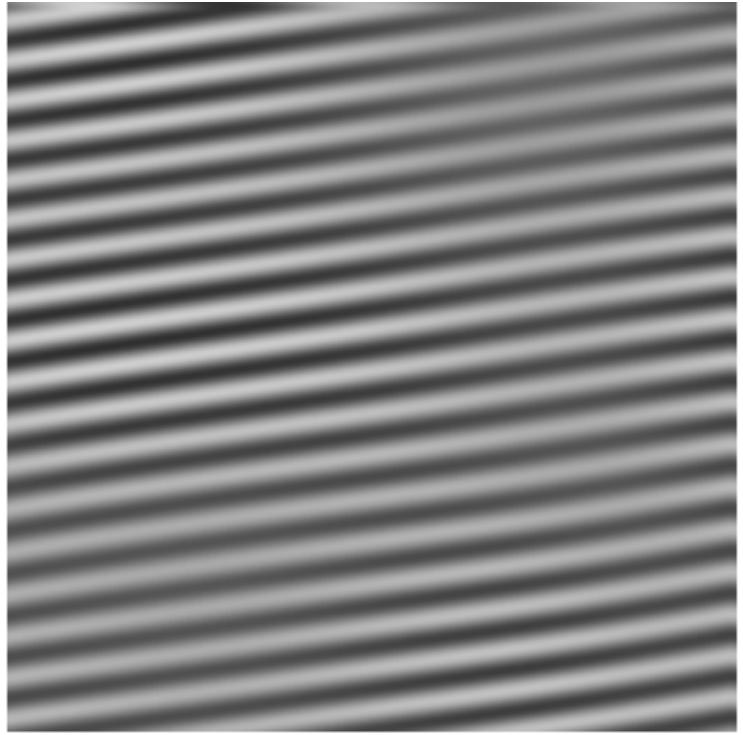

(b)

Figura 6.13: (a) Seleção das frequências da grade. (b) Transformada inversa. Ondulações provocadas pela difração do laser.
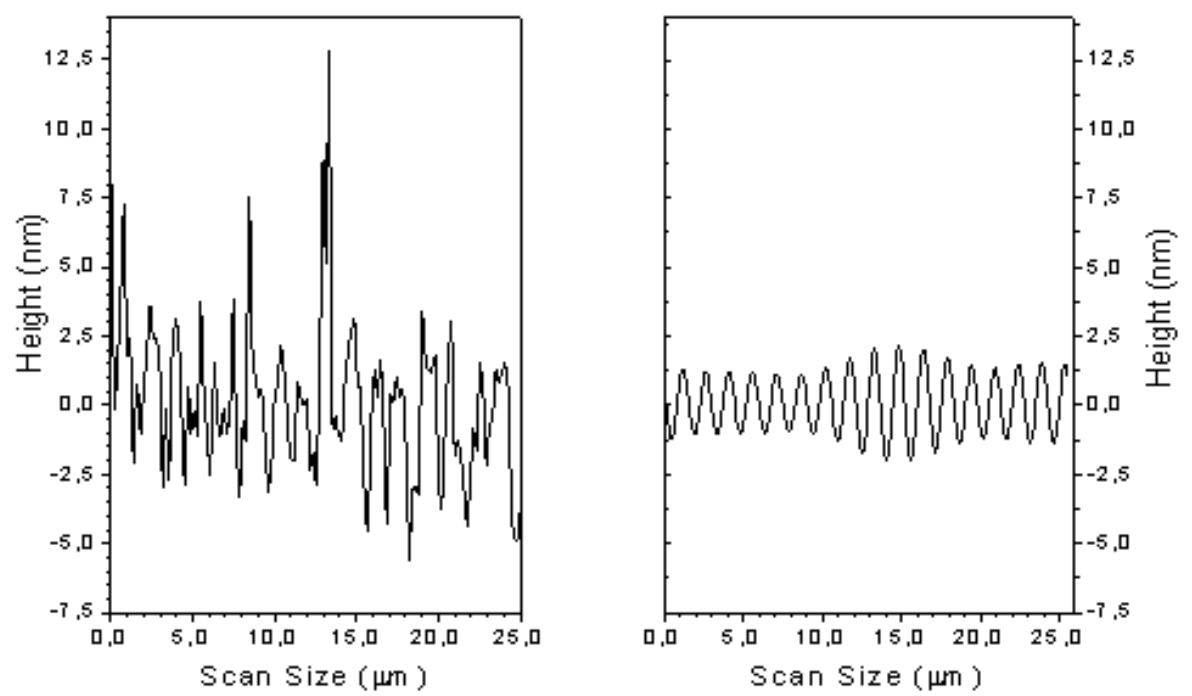

Figura 6.14: (a) Perfil da imagem da figura 6.11(a). (b) Perfil da imagem da figura 6.13(b). Há superposição de frequências visto que ocorreu a seleção de mais de uma frequência.

6.14 (a), possui uma média de 7.9nm. Este valor é menor que os obtidos normalmente em grades de relevo de superfície, em filmes azo-dopados, que em geral apresentam amplitude de modulação em torno de $100 \mathrm{~nm}$. Adicionalmente, a formação de grades de superfície na maioria das vezes é dependente da polarização, sendo mais eficientes para luz polarizada $p$ do que para polarização $s$. Nenhuma indicação da dependência deste tipo de polarização foi 
observada neste experimento. Isto leva a conclusão de que o processo de formação da grade é provavelmente um processo ocorrido no volume e não na superfície.

\subsection{Conclusão}

A análise quantitativa das imagens da figura 6.7 mostra que a morfologia da superfície sofreu modificações, indicada pela diminuição da rugosidade e aumento de picos durante a exposição ao laser em baixa potência.

Observamos que a análise visual da imagem de AFM não é suficiente, visto que os olhos não podem distinguir detalhes importantes da morfologia dos filmes poliméricos de PPV.

A análise estatística da imagem através do software SPIA mostrou a importância da quantificação dos parâmetros morfológicos, das alturas dos pontos (pixels) da imagem e das distâncias entre os primeiros picos vizinhos. Com a ajuda do software a interpretação da imagem torna-se mais confiável que a simples análise visual subjetiva.

Através do processo de foto-oxidação foi produzida uma grade de difração no filme PPV. A pequena diferença de $7.9 \mathrm{~nm}$ em altura pico-vale na superfície indica que o efeito principal ocorreu no volume, de acordo com evidências já conhecidas relacionadas com o aumento de PL [111]. 


\section{Capítulo 7}

\section{Curvatura espontânea de brushes de polímeros}

\subsection{Introdução}

Copolímeros densamente enxertados ou brushes moleculares tem recebido bastante atenção ultimamente [124]. O avanço no controle da estrutura molecular primária e de técnicas de manipulação da conformação molecular de tais brushes de alta ramificação as tornam intrigantes unidades básicas para dispositivos nanoscópicos [125].

O controle da conformação e o estudo de tais moléculas dependem da disponibilidade de ferramentas de análise que atinjam a escala nanométrica, bom contraste com respeito à composição química e propriedades físicas, monitoramento in-situ do movimento molecular e conformação numa resolução de tempo abaixo de milissegundos. Neste respeito, tanto o AFM e a análise de imagens têm-se mostrado ferramentas úteis para os avanços nesta área.

Estudos experimentais de brushes cilíndricas revelaram uma forma peculiar de brushes com uma backbone (cadeia principal) curva [124]. Foi também mostrado que o encurvamento espontâneo da backbone pode ser devido ou influenciado pela elasticidade entrópica das cadeias laterais: cadeias menores se encurvam mais devido a sua distribuição assimétrica com respeito a backbone[125]. No equilíbrio, a curvatura espontânea resulta de um balanço entre a elasticidade das cadeias laterais a elasticidade da interface, figura 7.1. Espera-se que a curvatura aumente com o aumento da cadeia lateral. 


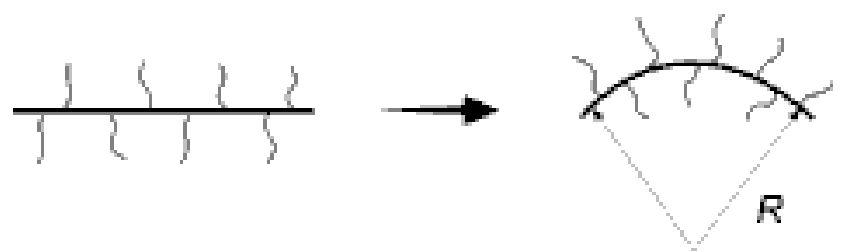

Figura 7.1: A curvatura espontânea de uma brush cilíndrica adsorvida em uma superfície plana pode ser induzida pela redistribuição das cadeias laterais relativas à backbone.

Neste capítulo, será apresentado um estudo sistemático da conformação de brushes cilíndricas com diferentes comprimentos de cadeias laterais. Para medir a conformação, foi utilizado o conceito de curvatura. A medida da curvatura envolve a aplicação de uma série de algoritmos numa sequência de procedimentos. Serão apresentados primeiro os algoritmos envolvidos, a metodologia para a extração da curvatura e alguns detalhes sobre a preparação das amostras. Em seguida serão apresentados os resultados, discussão e as conclusões. De acordo com a teoria, as brushes adsorvidas demonstram curvatura espontânea, no entanto observou-se que a curvatura diminuiu com o aumento da cadeia lateral. Este estudo foi feito em colaboração com o Prof. Sergei Sheiko da University of North Carolina e o Prof. Marcelo P. da Silva da UNICEP.

\subsection{Algoritmos envolvidos}

\subsubsection{Extração do contorno}

As coordenadas dos pixels do contorno da forma em uma imagem binária são obtidas através da aplicação do algoritmo de perseguição de contorno [6]. Através deste método, são obtidas as coordenadas dos pixels do contorno, no sentido horário ou anti-horário numa forma paramétrica. Esta particularidade importante se torna bastante útil numa série de aplicações, em especial para a posterior esqueletização do objeto.

Este método começa percorrendo inicialmente a matriz de pixels, que por convenção será adotada de cima para baixo e da esquerda para direita, conforme indicado na figura 7.2. Considerando que o fundo é branco, esta varredura termina quando encontrar o primeiro pixel preto nesta ordem. Após encontrá-lo o algoritmo percorre o contorno do objeto no 
sentido anti-horário até encontrar novamente o pixel inicial, encerrando o processo. Deste modo o contorno é obtido de tal modo que as coordenadas obtidas serão dos pixels ordenados no sentido anti-horário.

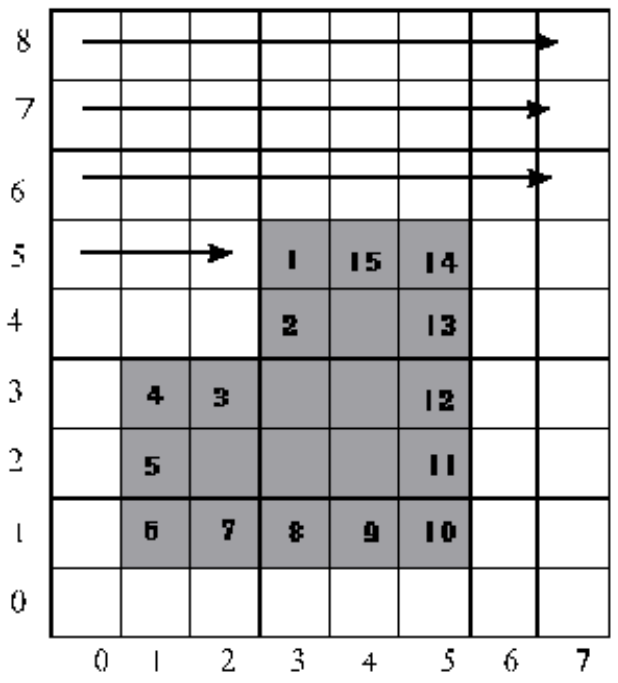

Figura 7.2: Esquema para o algoritmo de perseguição de contorno.

Para o contorno deste objeto, as coordenadas dos pixels seriam, na ordem: $(3,5),(3,4)$, $(2,3),(1,3),(1,2),(1,1),(2,1),(3,1),(4,1),(5,1),(5,2),(5,3),(5,4),(5,5),(4,5)$. Deste modo, o contorno é obtido em uma forma paramétrica.

Analisando o algoritmo de uma forma mais detalhada, cada pixel preto encontrado é guardado em uma lista, e também o pixel branco anterior ao pixel preto guardado. No exemplo da figura 7.2, o primeiro pixel preto possui coordenadas $(3,5)$ e o anterior branco, $(2,5)$. Para encontrar o próximo pixel do contorno, o algoritmo faz uma busca ao redor do pixel atual, até encontrar o próximo pixel preto. É como se o algoritmo "tateasse" ao redor do pixel preto em busca do próximo na sequência. Essa busca começa a partir do pixel branco anterior branco (já guardado) e continua no sentido anti-horário. Deste modo, o pixel anterior branco se torna responsável pela direção em que essa busca começa. As direções possíveis são mostradas na figura 7.3. O pixel P faz parte do contorno.

Voltando a figura 7.2, após o primeiro pixel preto ser guardado, a busca começa na direção do pixel branco anterior, que de acordo com a figura 7.3 é a direção 3. A busca continua até a direção 5. Nesta posição é encontrado o pixel 2 do contorno. Este pixel e o 


\begin{tabular}{|c|c|c|}
\hline 2 & 1 & 8 \\
\hline 3 & $P$ & 7 \\
\hline 4 & 5 & 6 \\
\hline
\end{tabular}

Figura 7.3: Vizinhança de oito para o pixel P do contorno.

anterior branco é guardado. Na próxima busca, a varredura começa na direção 3 novamente e continua até a direção 4, onde se encontra o pixel 3. E assim continua sucessivamente até que o pixel 1 seja encontrado novamente. Neste momento a busca termina e o último pixel guardado é o 16.

\subsubsection{Transformada Distância}

Dada uma imagem binária contendo algum objeto, de forma $C$, e um dos pontos externos ao objeto, que chamaremos de $P$, a distância $d(P, C)$ entre o ponto $P$ e a forma $C$ é definida como sendo a menor distância entre o ponto $P$ e qualquer um dos elementos do conjunto $C$. Este conceito é ilustrado na figura 7.4.

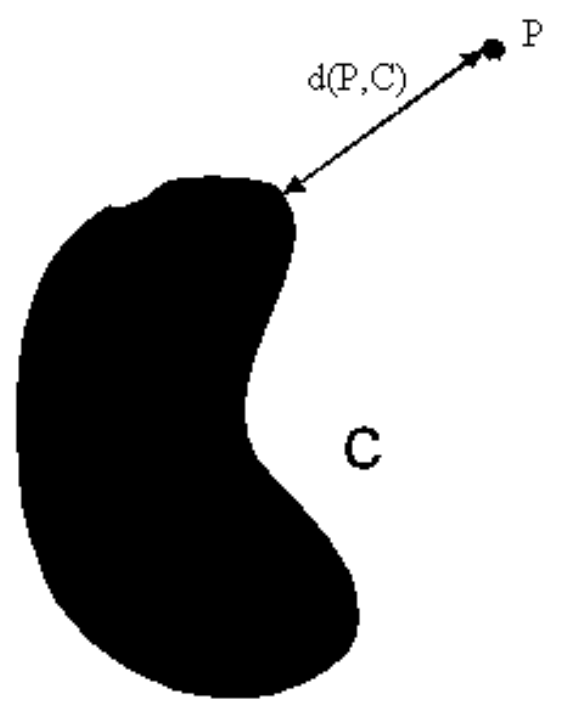

Figura 7.4: Distância d(P,C).

A transformada distância da forma $C$ pode ser então definida como o processo que atribui a cada ponto externo $P$ a $C$ a respectiva distância $d(P, C)$. A figura 7.5 mostra um objeto e a 
imagem correspondente à sua transformada distância, onde as distâncias foram convertidas em tons de cinza.
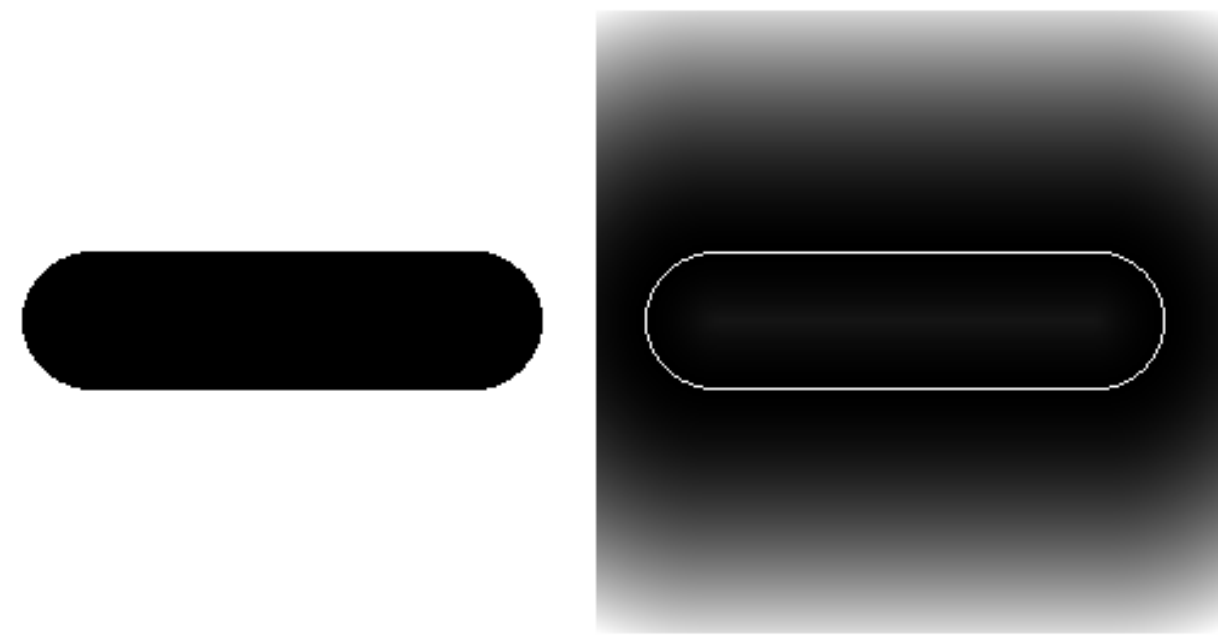

(a)

(b)

Figura 7.5: Objeto e visualização de sua transformada distância.

Convém salientar que para o cálculo da transformada distância foi necessário primeiro a extração da borda através do algoritmo de perseguição de contorno e a partir deste contorno foi aplicado o algoritmo da dilatação exata (veja a seção 5.2.2), onde cada ponto do contorno foi dilatado, calculada a distância correspondente e atribuída à imagem o tom de cinza correspondente, resultando na imagem da Figura 7.5(b). Sendo calculada a menor distância de um ponto externo ao contorno do objeto, este ponto é marcado como já calculado e não será calculado novamente.

\subsubsection{Esqueletização}

O processo de esqueletização é um método para a caracterização de formas. Embora não haja uma definição formal satisfatória para o esqueleto, pode-se entender de um modo informal como sendo uma representação de uma forma, tão estreita quanto possível e que se encontra ao longo da mediana interna da forma. Um dos conceitos matemáticos formais sobre esqueletos é conhecido como medial axis transform - MAT também conhecido como symmetry axis transform - SAT, descrito por Blum [126]. Fundamentalmente, a SAT de uma 
forma contínua corresponde a todas possíveis posições dos centros dos círculos satisfazendo as duas condições seguintes:

1. Ser bitangentes à forma, ou seja, toca a curva em dois pontos distintos;

2. Serem internos à forma.

A figura 7.6 mostra a forma de um retângulo e seu SAT (esqueleto).

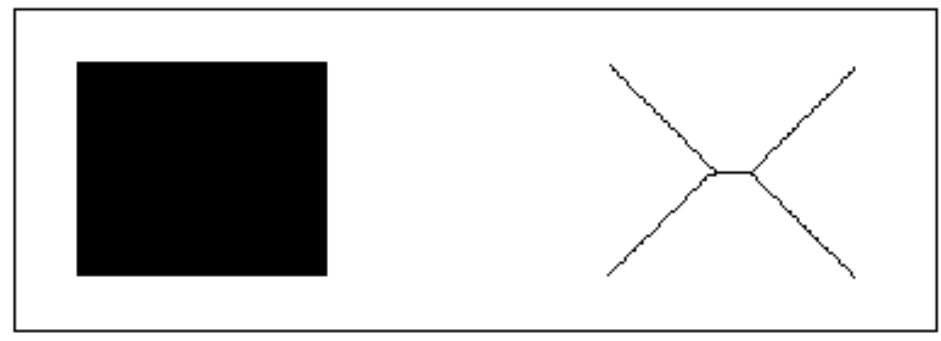

Figura 7.6: Retângulo e seu esqueleto.

OS elementos do SAT podem ser encarados como sendo as posições onde ondas propagantes com velocidade constante originárias da borda da forma se chocam umas com as outras, um conceito diretamente relacionado com as dilatações exatas já comentadas na seção 5.2.2. Visto que o esqueleto representa os centros dos círculos necessários para reconstituir a imagem, na figura 7.7 apresenta-se um histograma da quantidade de círculos necessários para reconstituir a forma do retângulo pelos raios correspondentes. Observa-se que há uma pequena variação nas colunas do histograma. Isto ocorre devido à natureza discreta da grade. A última coluna é maior porque corresponde aos raios da haste central, que reúne uma quantidade maior de círculos de mesmo raio.

No software SPIA, foi desenvolvido um algoritmo que controla a criação do esqueleto permitindo a reconstrução da imagem original a partir do esqueleto [6, 92]. Esta técnica é baseada novamente no conceito de dilatações exatas. Mais especificamente, começamos rotulando os pontos do contorno da forma com valores inteiros sucessivos, tais como ilustrados na figura $7.8(\mathrm{~b})$. 


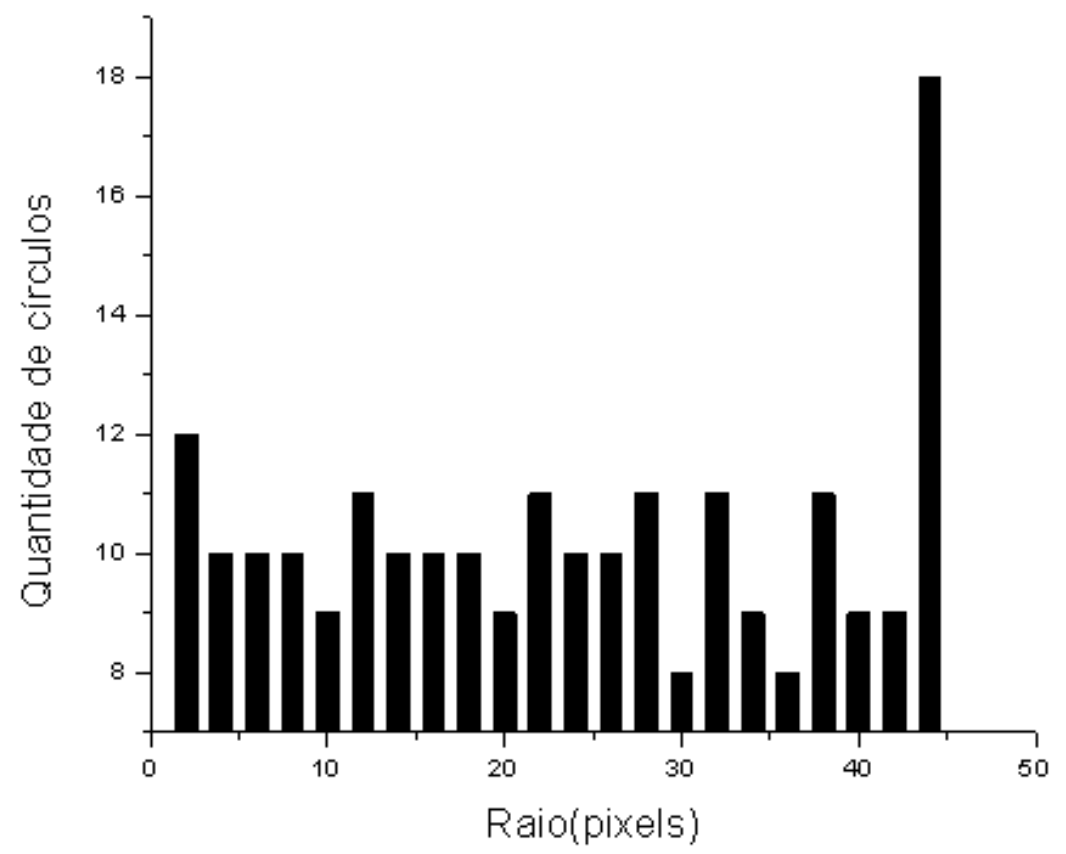

Figura 7.7: Histograma dos raios necessários para a reconstrução do retângulo da figura 7.6

Isto é conseguido com o algoritmo de perseguição de contorno que extrai a borda no sentido anti-horário. Depois, os rótulos (números atribuídos a cada ponto do contorno) são propagados através das dilatações exatas fornecendo uma matriz de rótulos, conforme vista na figura 7.8 (c). Uma vez obtida esta imagem, a diferença máxima entre rótulos dos quatro pixels vizinhos é determinada e atualizada em uma imagem de diferenças. Uma família inteira de esqueletos é obtida simplesmente aplicando-se diversos limiares na imagem das diferenças. A Figura 7.9 apresenta a imagem do contorno de um polímero (a), sua transformada distância(b), os rótulos propagados (c) e a imagem das diferenças(d).

$\mathrm{Na}$ imagem de diferenças, os maiores valores correspondem aos contornos mais distantes e os menores valores aos contornos próximos. Isto significa que se fizermos uma limiarização desta matriz de diferenças poderemos remover os detalhes da imagem. Isto permite que se faça uma reconstituição da imagem por aplicar diversos valores de limiar na matriz de diferenças da figura 7.9, conforme exemplificado na figura 7.10.

A esqueletização será aplicada para a extração da backbone das moléculas, possibilitando uma série de medidas como o comprimento ponta a ponta e posteriormente a curvatura. 


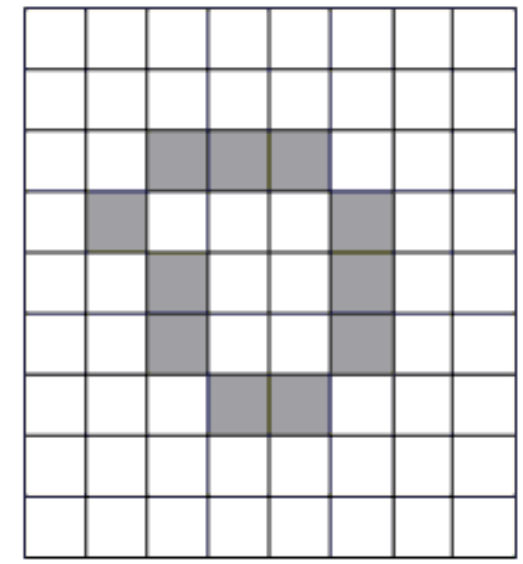

(a)

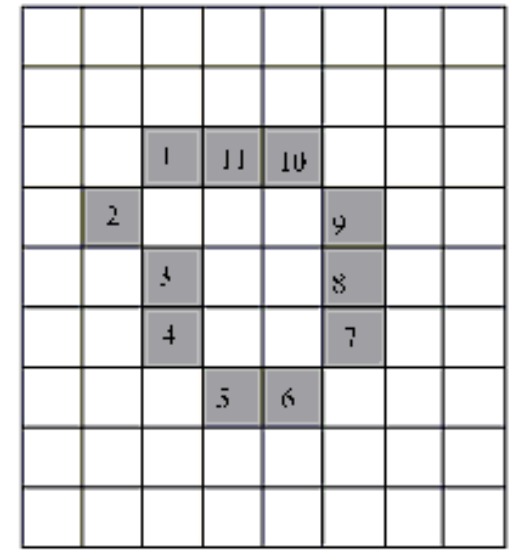

(b)

\begin{tabular}{|c|c|c|c|c|c|c|c|}
\hline & 1 & 1 & 11 & 10 & 10 & & \\
\hline 1 & 1 & 1 & 11 & 10 & 10 & 4 & \\
\hline 2 & 1 & 1 & 11 & 10 & 10 & 9 & 9 \\
\hline 2 & 2 & 1 & 11 & 10 & 9 & 9 & 5 \\
\hline 3 & 3 & 3 & 3 & 8 & 8 & 8 & 8 \\
\hline 3 & 4 & 4 & 4 & 7 & 7 & 8 & 8 \\
\hline+ & 1 & 5 & 5 & 6 & 7 & 7 & 7 \\
\hline & 5 & 5 & 5 & 4 & 5 & 4 & 7 \\
\hline & & 5 & 5 & 4 & 6 & 6 & 7 \\
\hline
\end{tabular}

(c)

Figura 7.8: (a) Pixels do contorno. (b) Contorno rotulado. (c) Propagação dos rótulos.

\subsubsection{Curvatura}

Uma das expressões utilizadas para o cálculo da curvatura é dada pela equação [127]:

$$
k=\frac{\dot{x(t) y \ddot{(t})}-\ddot{x}(t) y(t)}{\left(\dot{x(t)^{2}}+\dot{y(t)}^{2}\right)^{3 / 2}}
$$

onde $x(t)$ e $y(t)$ representam as coordenadas parametrizadas do contorno da forma a ser analisada. As derivadas são feitas em relação ao parâmetro $t$, que representa o rótulo ou posição da coordenada no contorno. Para se calcular a curvatura é necessário estimar a primeira e segunda derivada dos sinais $x(t)$ e $y(t)$. Seja $X(f)$ e $Y(f)$ as transformadas de Fourier 

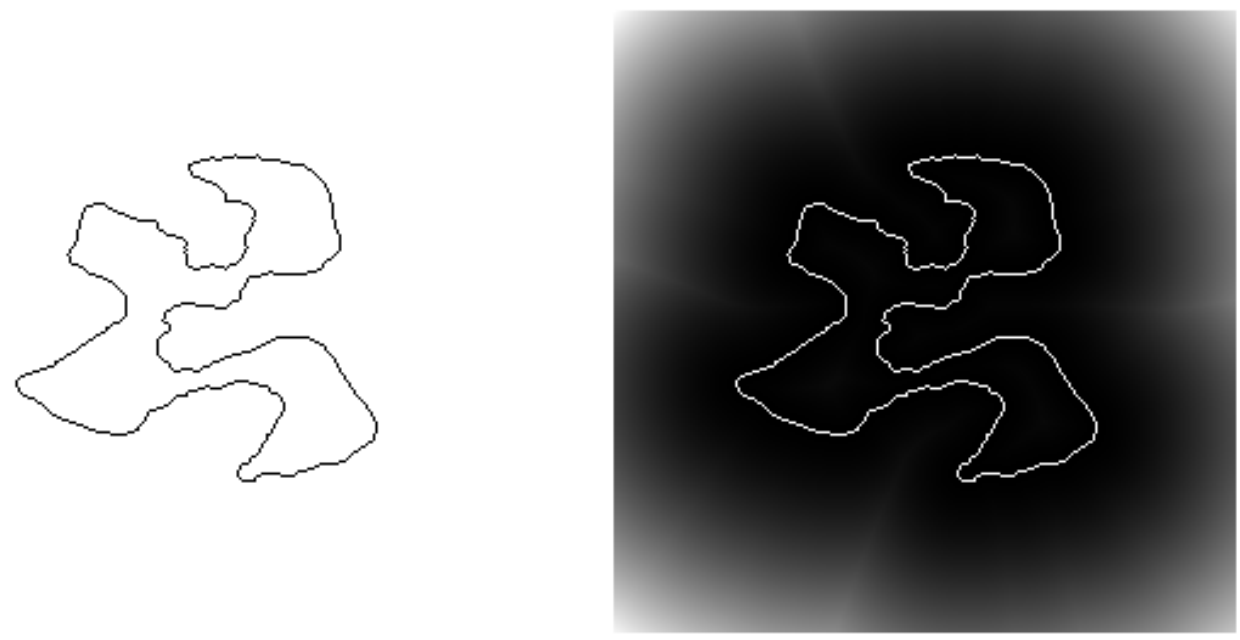

(a)

(b)

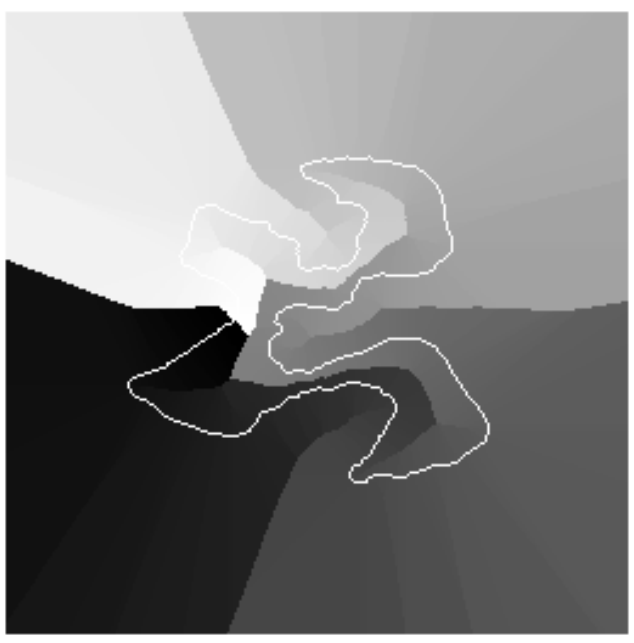

(c)

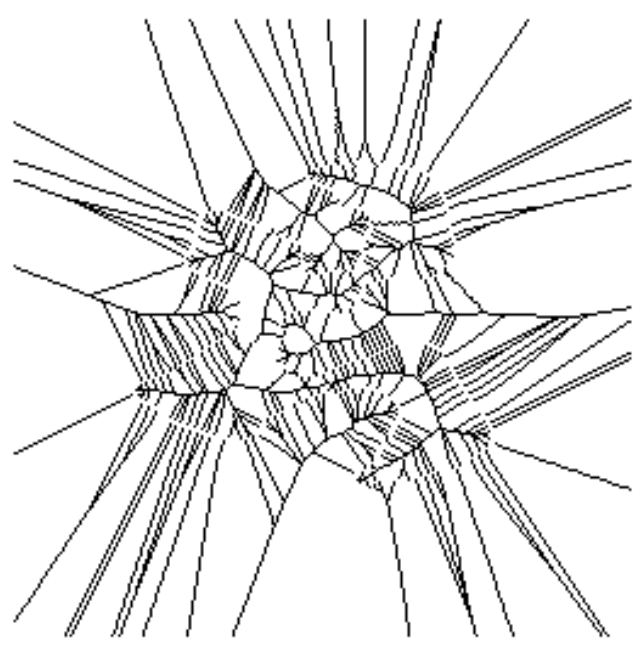

(d)

Figura 7.9: (a) Contorno. (b) Transformada Distância. (c) Rótulos propagados. (d) Imagem das diferenças.

de $x(t)$ e $y(t)$. Aplicando-se a propriedade da derivada da transformada de Fourier [128] temos que:

$$
\dot{X}(f)=i 2 \pi X(f)
$$

$$
\dot{Y}(f)=i 2 \pi Y(f)
$$

$$
\ddot{X}(f)=-(2 \pi f)^{2} \dot{X}(f)
$$




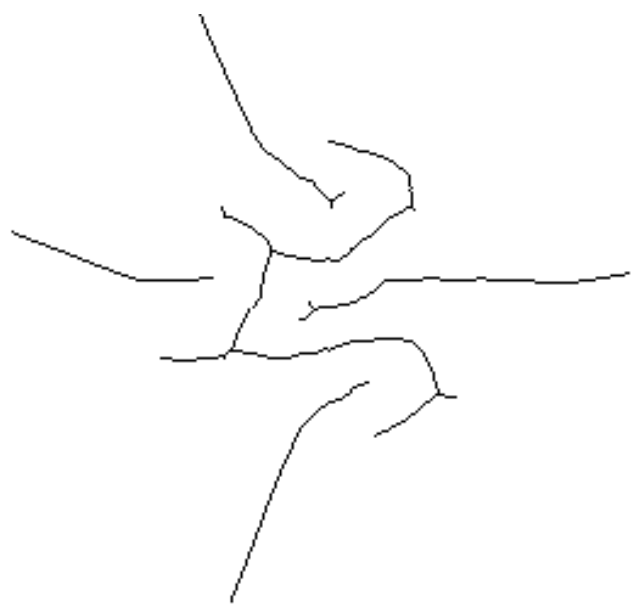

(a)

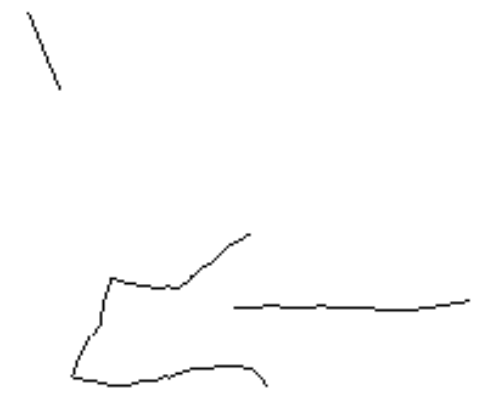

(c)

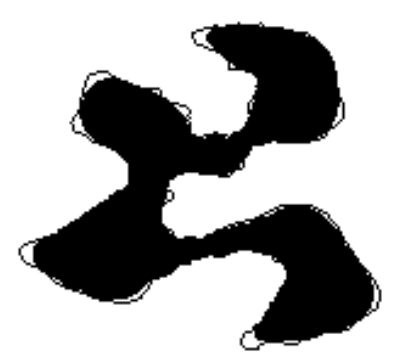

(b)

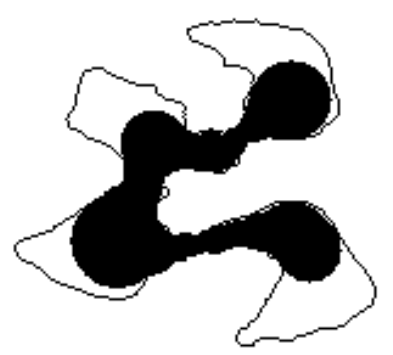

(d)

Figura 7.10: (a) e (b) Reconstrução para limiar 20. (c) e (d) Reconstrução para limiar 120.

$$
\ddot{Y}(f)=-(2 \pi f)^{2} \dot{Y}(f)
$$

onde $i=\sqrt{(}-1)$ e as abreviações $\dot{X}(f), \dot{Y}(f), \ddot{X}(f)$ e $\ddot{Y}(f)$ representam as transformadas de Fourier de $\dot{x}(t), \dot{y}(t), \ddot{x}(t)$ e $\ddot{y}(t)$ respectivamente e não as derivadas com respeito a variável de freqüência $f$. Assim, a aplicação da propriedade acima seguida pela transformada inversa de Fourier permite a estimativa da curvatura por se aplicar a equação 7.10 em termos das transformadas de Fourier dos sinais $x(t)$ e $y(t)$,

$$
\dot{x}(t)=\digamma^{-1}\{\dot{X}(f)\}
$$




$$
\begin{aligned}
& \dot{y}(t)=\digamma^{-1}\{\dot{Y}(f)\} \\
& \ddot{x}(t)=\digamma^{-1}\{\ddot{X}(f)\} \\
& \ddot{y}(t)=\digamma^{-1}\{\ddot{Y}(f)\}
\end{aligned}
$$

Aplicando estes resultados na equação 7.10 obtém-se a curvatura do sinal.

A diferenciação obtida por este método pode ser encarada como uma filtragem passa alta devido ao sinal na frequiência ser multiplicado por $f$. Por conseguinte, ruídos de alta freqüência são acentuados. Este efeito indesejável pode ser atenuado através da introdução de uma filtragem controlada pelo seu desvio padrão, $\sigma$, no processo de estimativa da curvatura. Esta metodologia tem sido eficiente numa série de aplicações [63, 6, 129, 130, 131]. Neste contexto, a diferenciação baseada na propriedade de Fourier deve ser combinada com a filtragem passa baixa proporcionada pela Gaussiana, a fim de se atenuar as altas freqüências. A filtragem é obtida convoluindo-se o sinal com a gaussiana, no espaço. Considerando o teorema da convolução, que declara que a convolução no domínio do espaço é igual a multiplicação no espaço das freqüências [3], a filtragem do contorno pode ser obtida simplesmente multiplicando-se a transformada da gaussiana às equações 7.2, 7.3, 7.4, 7.5 antes de se processar a transformada inversa de Fourier,

$$
\begin{gathered}
g(t)=\frac{1}{\sigma \sqrt{2 \pi}} e^{-\frac{t^{2}}{2 \sigma^{2}}} \\
\dot{X}(f)=i 2 \pi X(f) G(f) \\
\dot{Y}(f)=i 2 \pi Y(f) G(f)
\end{gathered}
$$




$$
\begin{aligned}
& \ddot{X}(f)=-(2 \pi f)^{2} \dot{X}(f) G(f) \\
& \ddot{Y}(f)=-(2 \pi f)^{2} \dot{Y}(f) G(f)
\end{aligned}
$$

O sinal no espaço das freqüências é constituído principalmente de baixas frequências. Isto significa que para altos valores de desvio padrão, o sinal será atenuado em sua amplitude pela gaussiana. Isto provoca um "encolhimento" no contorno. A figura 7.11 mostra o encolhimento do contorno após o processo da filtragem das altas frequências. Por este motivo será aplicada uma compensação a fim de contornar este problema [63, 6].
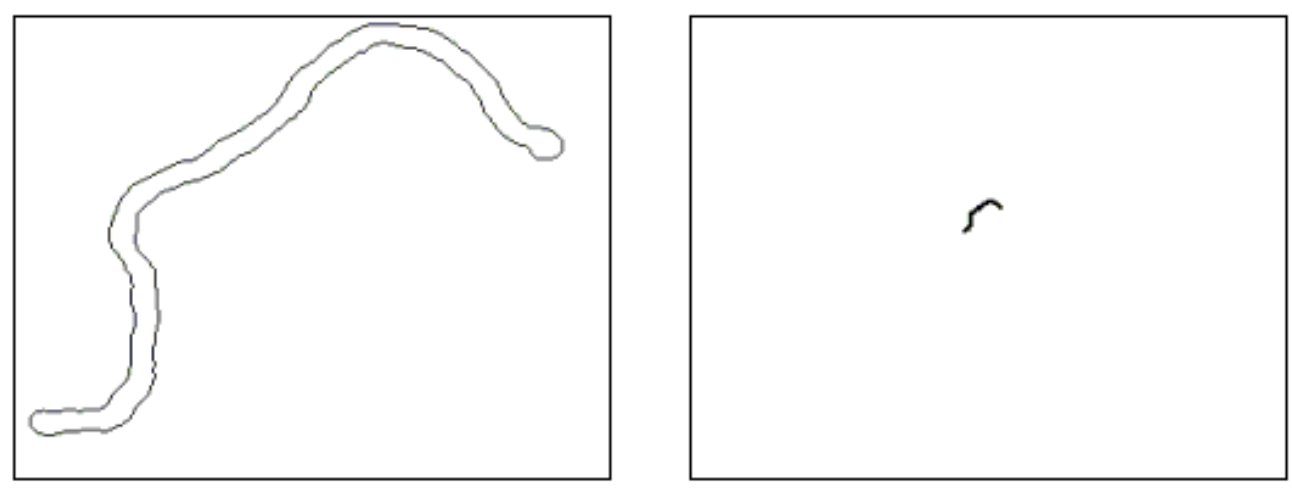

Figura 7.11: Contorno e encolhimento após filtragem.

Esta compensação consiste em manter constante a energia do sinal após a filtragem. A energia total dos sinais que correspondem as coordenadas $x$ e $y$ parametrizadas podem ser definidas como a soma de todos os componentes espectrais do sinal do seu respectivo espectro de potência, de acordo com as equações,

$$
\begin{aligned}
& E_{x}=\sum\left(X(f) \cdot X^{*}(f)\right) \\
& E_{y}=\sum\left(Y(f) \cdot Y^{*}(f)\right)
\end{aligned}
$$

A energia do contorno após a filtragem pela gaussiana $G(f)$ é definida por, 


$$
\begin{aligned}
& E_{f x}=\sum\left(X G(f) \cdot X G^{*}(f)\right) \\
& E_{f y}=\sum\left(Y G(f) . Y G^{*}(f)\right)
\end{aligned}
$$

Deste modo, a compensação será obtida por,

$$
\begin{aligned}
& \Omega_{x}=\sqrt{\frac{E_{x}}{E_{f x}}} \\
& \Omega_{y}=\sqrt{\frac{E_{y}}{E_{f y}}}
\end{aligned}
$$

Este coeficiente escalar $\Omega$ deverá ser multiplicado às derivadas das coordenadas $x$ e $y$ reconstruídas pela transformada de Fourier. Esta técnica tem se mostrado eficiente [63], especialmente porque a energia do sinal está concentrada nos primeiros componentes espectrais no caso de contornos típicos processados em análise de imagens e visão computacional. De outro modo, a atenuação das altas frequências pelo processo de filtragem gaussiana degradaria a estratégia de compensação por energia.

\subsection{Procedimento para obtenção da curvatura das macro- moléculas}

Nosso objetivo é extrair a curvatura ao longo da molécula. Inicialmente a imagem é ampliada de modo que cada pixel corresponda a $1 \mathrm{~nm}$. Depois, é limiarizada a fim de se segmentar as moléculas cujas curvaturas se deseja medir. O resultado é uma imagem binária, como pode ser vista na figura 7.12.

O software, além de fazer o limiar, elimina objetos na imagem de 300 ou menos pixels, por serem irrelevantes e não representarem corretamente uma molécula. Da imagem binária, foram extraídos os contornos de todas as moléculas, utilizando-se o algoritmo de perseguição 


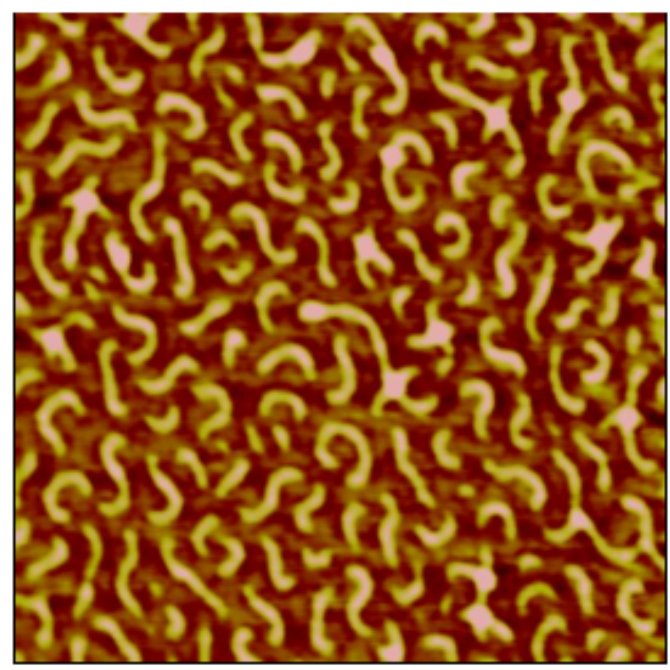

(a)

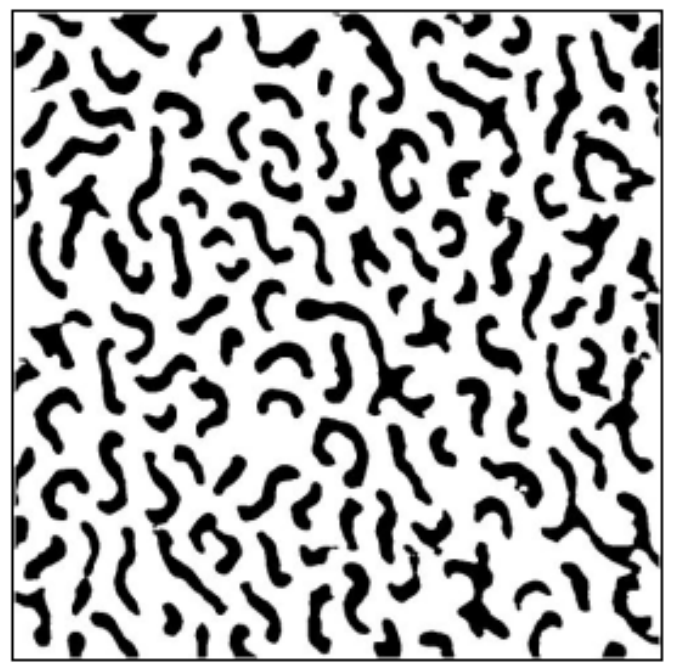

(b)

Figura 7.12: (a) Imagem de brushes. (b) Imagem limiarizada, limiar $=130$. Varredura: $1 \times 1$ $\mu m^{2}$.

de contorno, citado anteriormente. A partir do contorno são extraídos os esqueletos internos de todas as moléculas, escolhendo-se um limiar suficiente para que seja criado o eixo principal da molécula ou backbone. A vantagem deste método de esqueletização é que a sua largura é de um pixel, facilitando a identificação das extremidades e pontos de junção. O resultado pode ser observado na figura 7.13.

No entanto, os esqueletos ainda não estão numa boa representação para se extrair a curvatura. É importante remover os pequenos ramos e esqueletos com mais de duas extremidades. Para isso, todas as extremidades e pontos de junção são identificados. Isto é feito por se analisar a vizinhança de todos os pixels para a devida classificação. O pixel será extremidade se ele tiver apenas um vizinho. A figura 7.14 mostra as situações possíveis.

Uma outra situação que caracteriza uma extremidade é quando o pixel tem dois vizinhos que são vizinhos entre si. Este caso pode ser visto na figura 7.15.

Os pontos de junção possuem ao menos três vizinhos. As 16 possibilidades são mostradas na figura 7.16 .

Alguns pixels com três vizinhos e que não são pontos de junção são eliminados por serem irrelevantes. A figura 7.17 mostra quais são essas situações. 


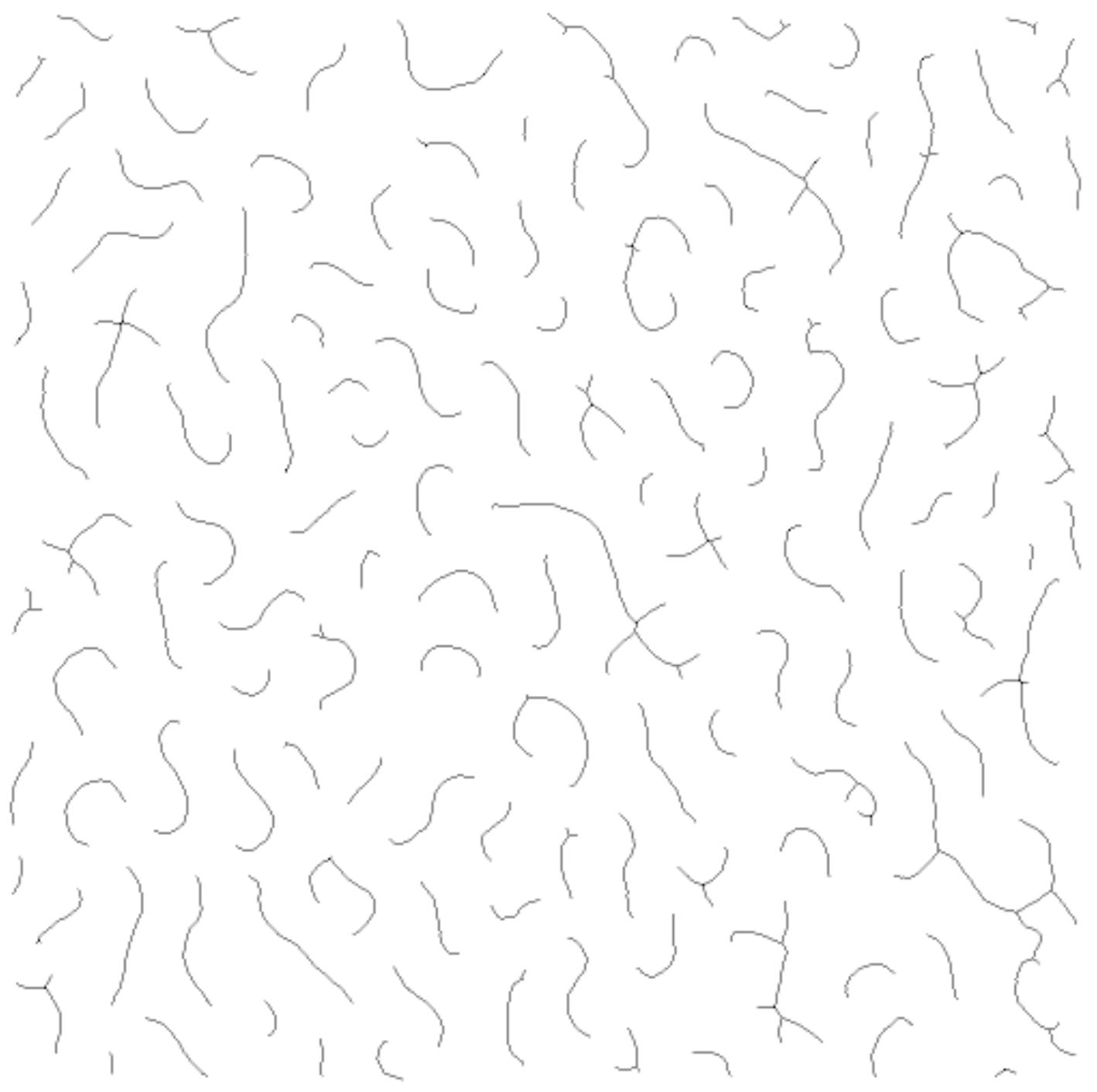

Figura 7.13: Esqueletos das brushes.
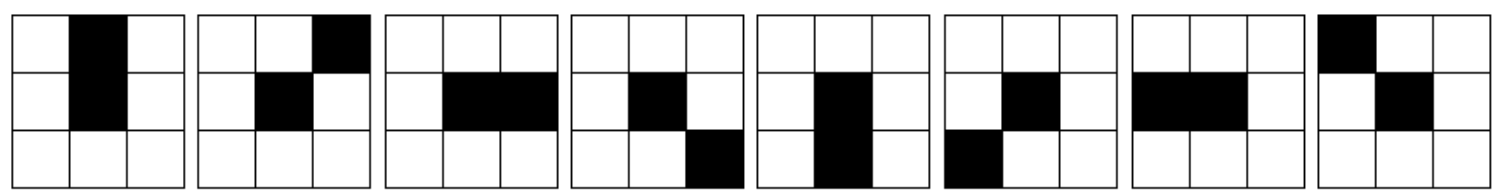

Figura 7.14: Situações de uma vizinhança. O pixel analisado é o central. Neste caso trata-se de uma extremidade.
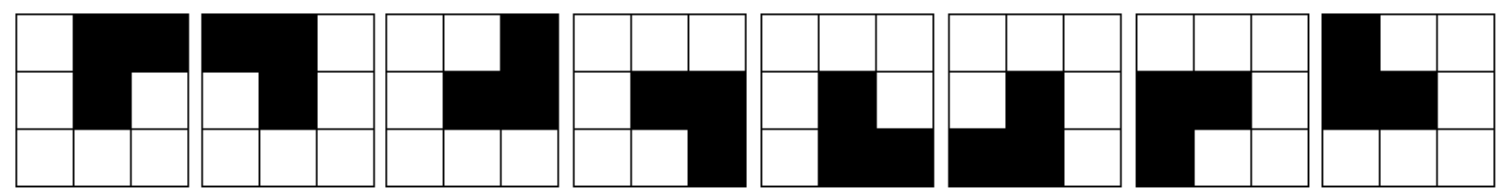

Figura 7.15: Situações de duas vizinhanças. Os vizinhos são vizinhos entre si. O pixel central é extremidade. 


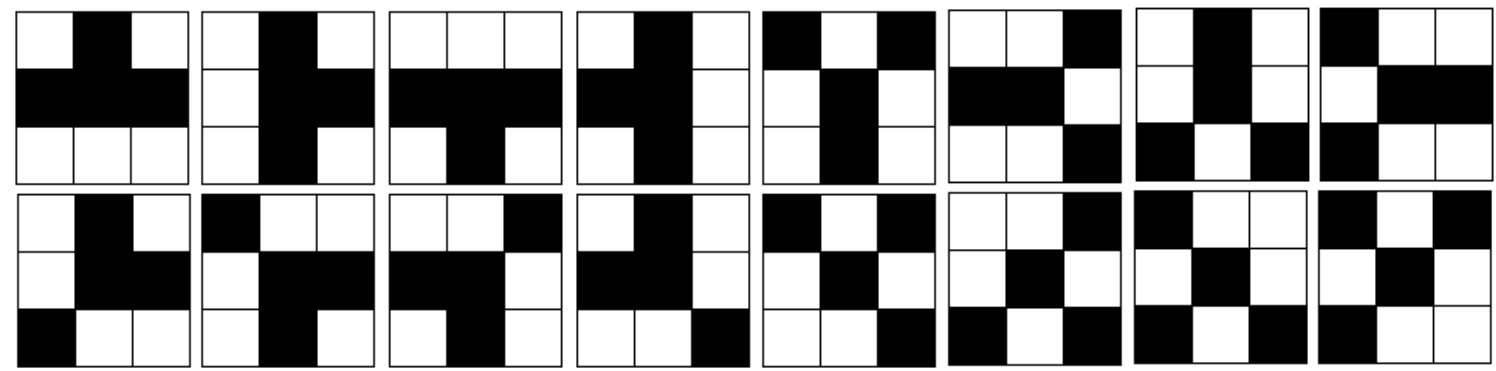

Figura 7.16: Os pontos de junção possuem ao menos três vizinhos que não são vizinhos entre si.

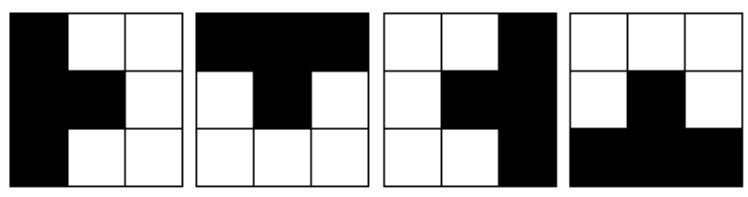

Figura 7.17: Nestes casos os pixels do centro são eliminados por serem irrelevantes.

O próximo passo é calcular as distâncias dos pontos de junção às extremidades, para determinar o comprimento dos ramos. Deste modo, ramos de comprimento menor ou igual a 15 pixels são eliminados e o resultado pode ser visto na figura 7.18.

A partir desta imagem, esqueletos com mais de duas pontas são eliminados por não representarem brushes. Visto que o software guardou uma lista de todos os pontos de junção, os esqueletos que possuem esses pontos de junção são completamente apagados e o resultado é que restam apenas as backbones das moléculas, conforme a figura 7.19.

Será a partir dessas backbones que a curvatura será medida. O algoritmo de estimação de curvatura funciona bem para sinais periódicos, visto que utiliza a transformada discreta de Fourier. Por este motivo é necessário fazer a dilatação de um pixel em cada lado dos pixels da backbone para que se extraia seu contorno. Isto foi feito de acordo com as regras da morfologia matemática para dilatação [6]. A dilatação é mostrada na figura 7.20.

Agora, pode-se extrair a curvatura dessas backbones. O algoritmo obtém a curvatura ao longo de todos os pontos do contorno. Sendo assim, torna-se necessário escolher um dos lados do contorno que será adotado como a curvatura das backbones. Para isso foram encontradas as posições dos pontos de maior curvatura, correspondendo às extremidades, e um mesmo lado foi escolhido para todas as backbones, de uma extremidade para outra 


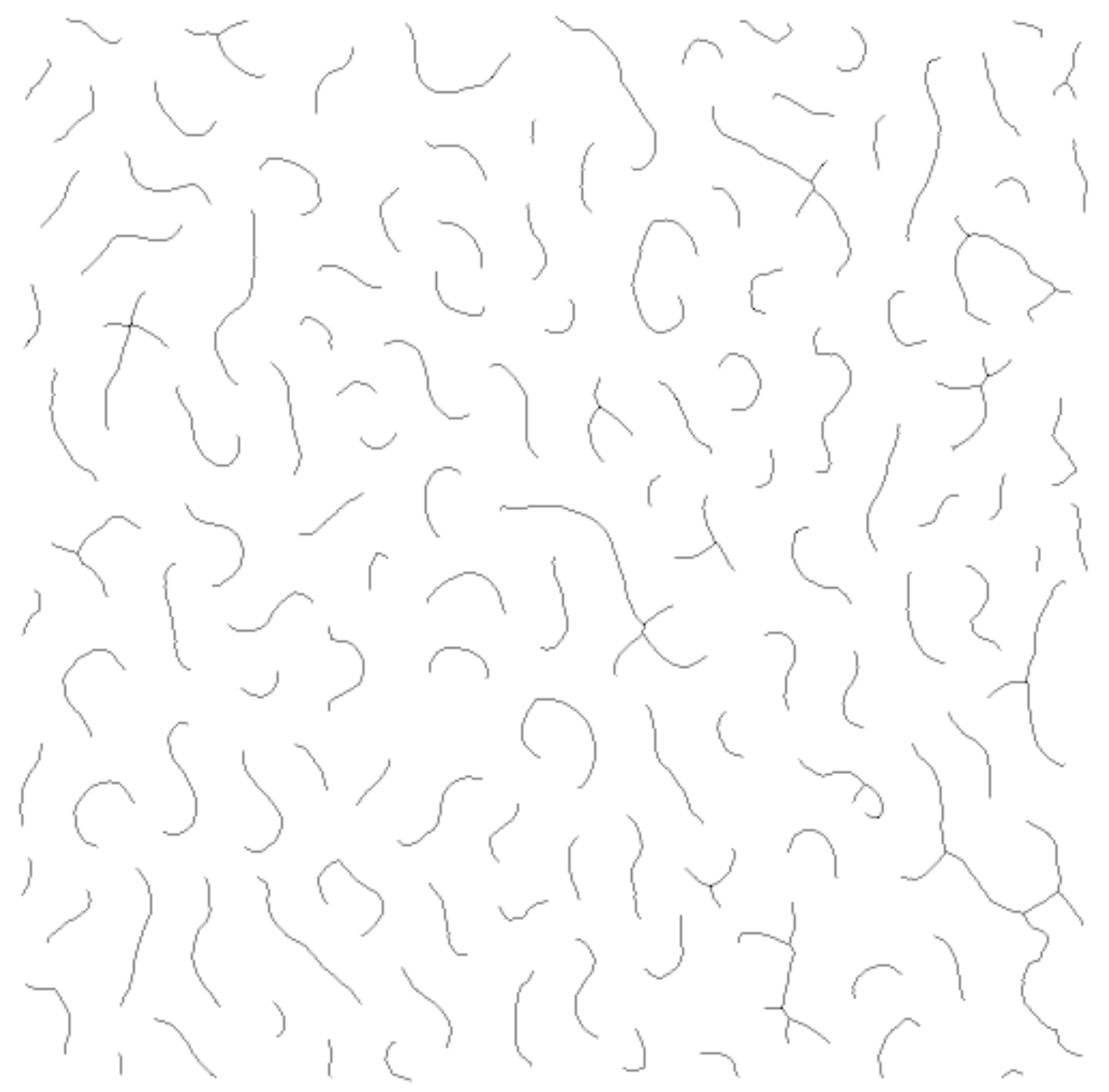

Figura 7.18: Situação dos esqueletos após a eliminação dos ramos pequenos.

extremidade. O critério escolhido foi o sentido anti-horário, partindo da extremidade mais próxima da origem, até a outra extremidade. Após a escolha do lado, as curvaturas muito altas das extremidades foram rejeitadas.

A escolha do desvio padrão da gaussiana para a filtragem multiescala foi feita depois de se realizarem alguns testes em algumas imagens para validação do algoritmo. As imagens escolhidas são semicírculos de raios 60, 40 e 25, que correspondem as curvaturas usuais em imagens das brushes, veja a figura 7.21.

A figura 7.22 mostra o gráfico para a curvatura total do semicírculo de raio 60 e sigma 5 . Este gráfico mostra a curvatura para as duas concavidades ou lados, sendo uma negativa e a 


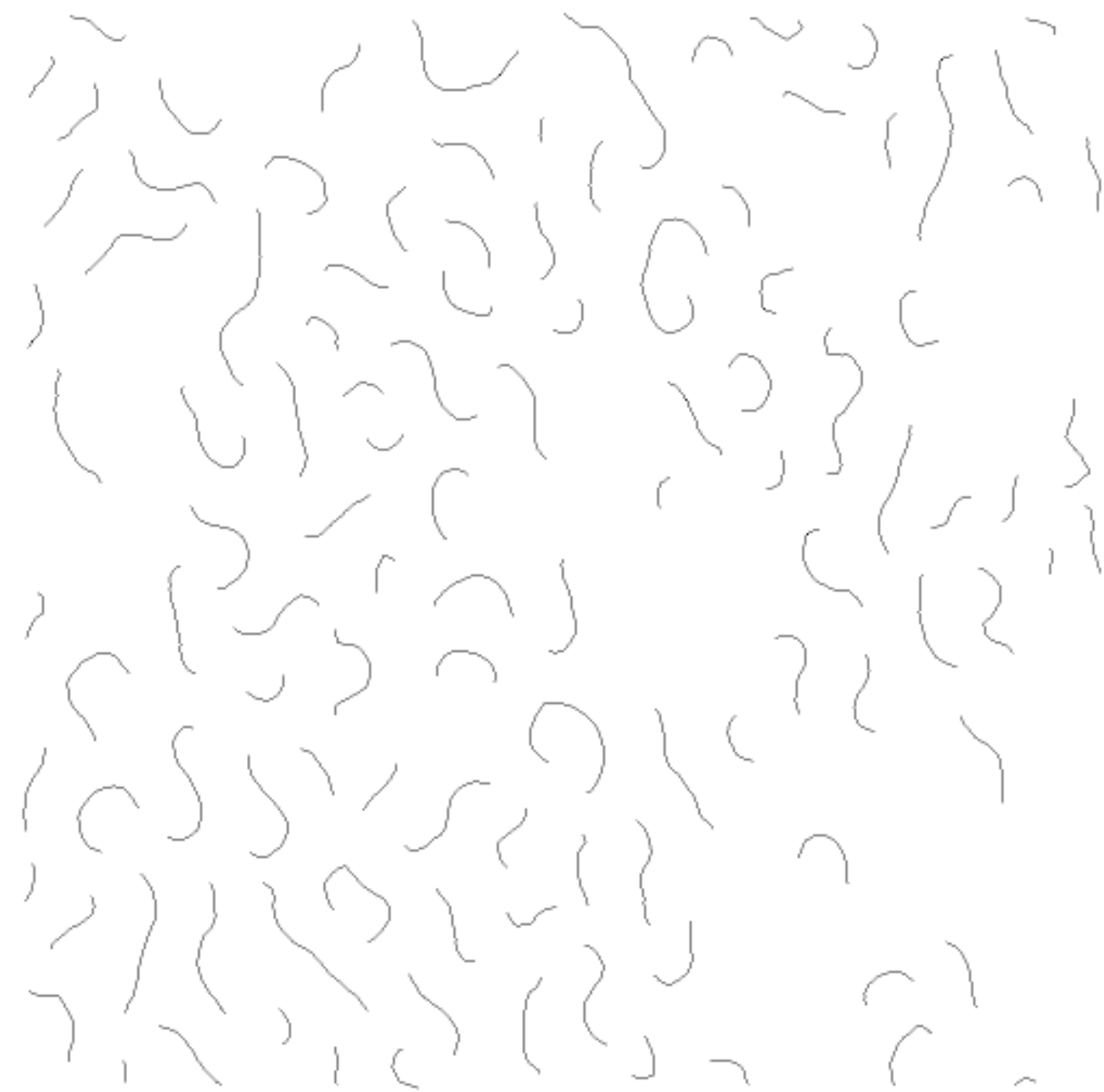

Figura 7.19: Após a eliminação dos esqueletos com mais de três pontas, restam apenas as backbones.

outra positiva de acordo com o sentido escolhido. O gráfico mostra também duas curvaturas altas, correspondendo às extremidades.

Percebe-se uma pequena variação em torno do valor correto devido ao fato de que estamos fazendo uma medida numa grade discreta e não contínua. A precisão da medida para um determinado lado pode ser verificada através dos resultados das medidas para vários sigmas (desvio padrão) da gaussiana que são mostrados nas tabelas 7.1, 7.2, 7.3.

Nesta tabela, sigma representa o desvio padrão da gaussiana para a filtragem multiescala, média refere-se a média da curvatura do lado do semicírculo, desvio padrão é o desvio da curvatura em relação a média e correção é a correção através da conservação da energia do 


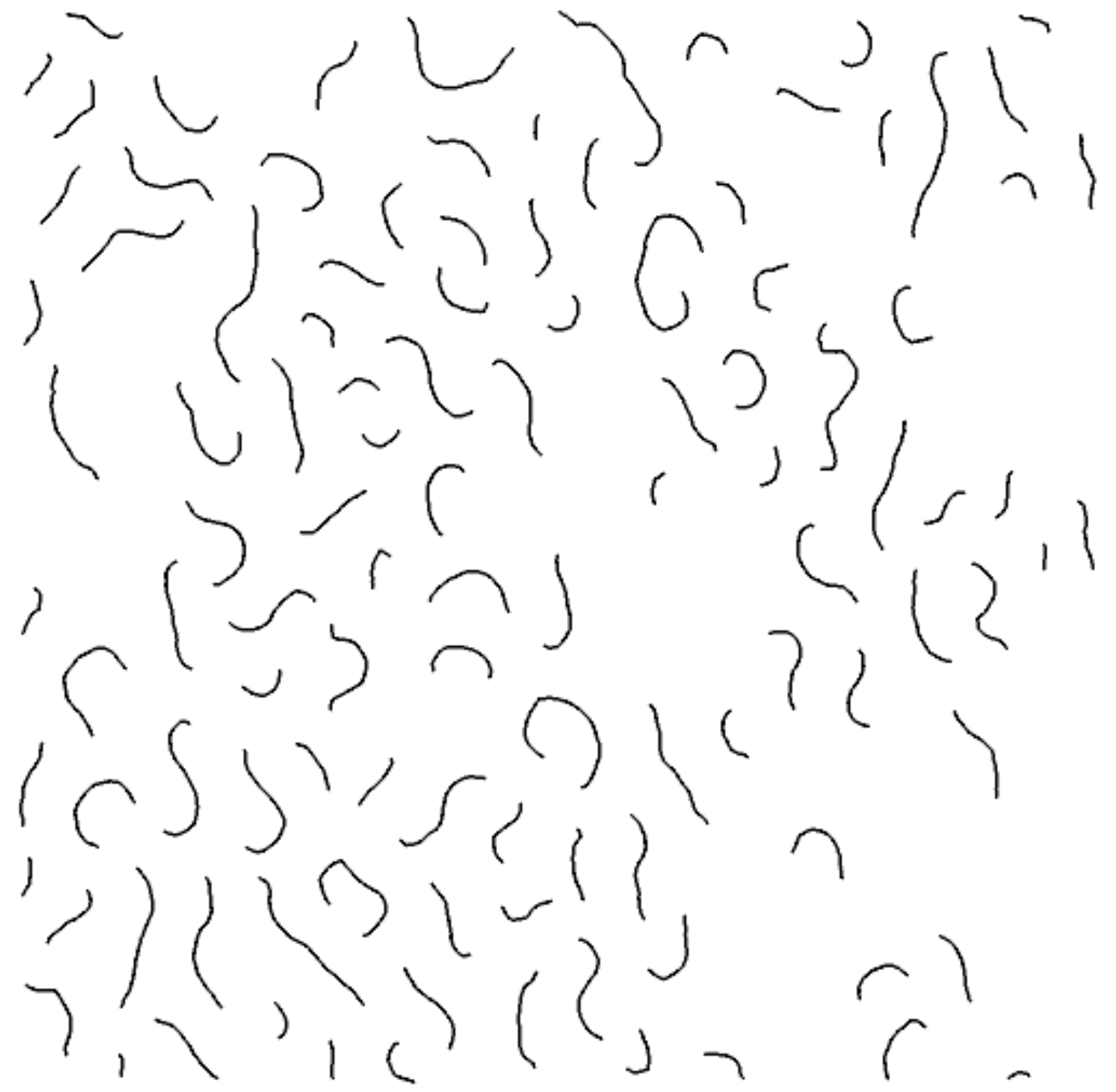

Figura 7.20: Todos os pixels das backbones foram dilatados em um pixel de cada lado.

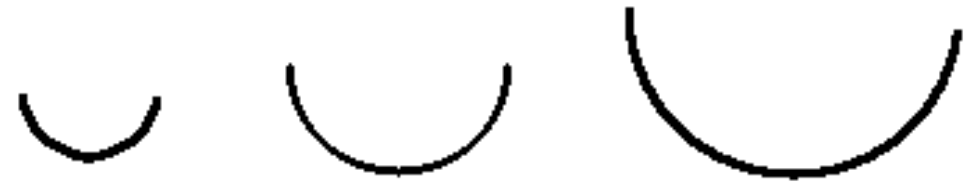

Figura 7.21: Semi-círculos de raios 25, 40 e 60, respectivamente.

sinal.

Estes resultados mostram que os melhores valores para sigma estão entre 4 e 5, pois obtiveram uma melhor média, menor desvio padrão e menor erro RMS. Esta conclusão está de acordo com os testes feitos por Estrozi et al. [132] ao aplicar este mesmo algoritmo em formas $1 \mathrm{D}$ e $2 \mathrm{D}$. 


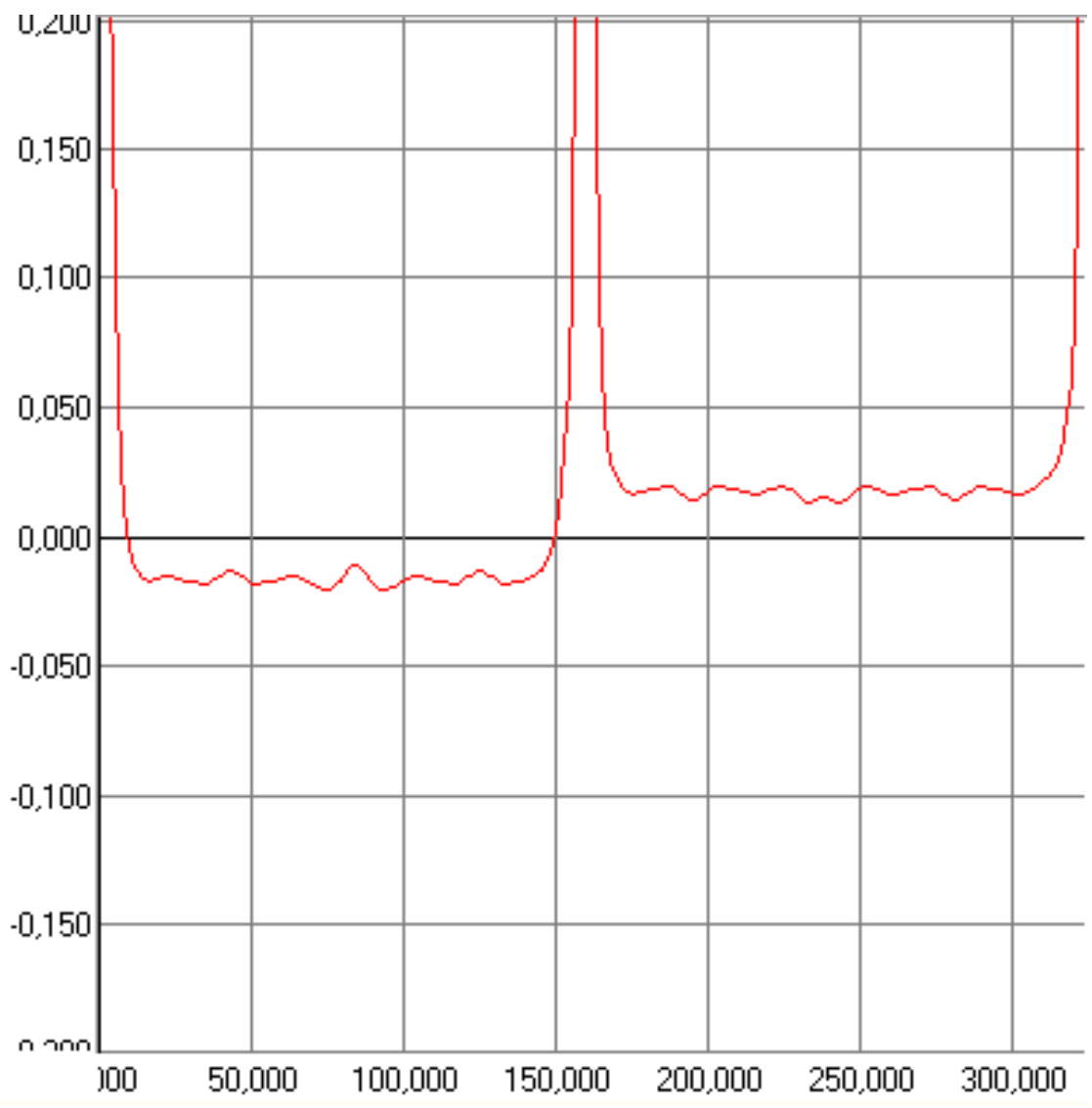

Figura 7.22: Curvatura total do contorno do semicírculo de raio 60 .

A figura 7.23 mostra o histograma das curvaturas da figura 7.20 através do método descrito até aqui. Neste histograma, as curvaturas negativas representam concavidades para um lado e as positivas, concavidades para outro lado. O pico do meio indica que há vários segmentos nos esqueletos das brushes que são aproximadamente retilíneos e outros trechos que são curvos, de curvatura em torno de 0.017 , correspondendo a um raio de curvatura $1 / 0.017=58.82 \mathrm{~nm}$.

A figura 7.24 mostra a mesma imagem das backbones, mostrando em vermelho os pontos de curvatura menor que 0.01 em módulo (seriam intervalos aproximadamente retilíneos) e em azul os pontos de curvatura maior que 0.01 . Esta figura serve para uma análise visual da eficiência do algoritmo de curvatura aplicado em brushes.

Observando-se esta figura, percebe-se que o algoritmo detectou razoavelmente os intervalos de maior e menor curvaturas. Por outro lado, alguns intervalos aparentemente retilíneos produziram curvaturas altas e vice-versa. Isto se dá pelo fato de que ao utilizar a transfor- 
Tabela 7.1: Raio 25. Curvatura exata $=0,04$.

\begin{tabular}{|l|l|l|l|l|l|}
\hline Sigma & Erro RMS & Média & $\begin{array}{l}\text { Desvio } \\
\text { Padrão }\end{array}$ & $\begin{array}{l}N^{o} \text { de pon- } \\
\text { tos }\end{array}$ & Correção \\
\hline \hline 3 & 0,015 & $-0,0438$ & 0,0148 & 42 & 1,00006 \\
\hline 4 & 0,011 & $-0,0429$ & 0,0107 & 42 & 1,00010 \\
\hline $5 *$ & 0,009 & $-0,0413$ & 0,0096 & 42 & 1,00015 \\
\hline 6 & 0,011 & $-0,0394$ & 0,0109 & 42 & 1,00021 \\
\hline 7 & 0,012 & $-0,0379$ & 0,0124 & 42 & 1,00029 \\
\hline
\end{tabular}

Tabela 7.2: Raio 40. Curvatura exata $=0,025$

\begin{tabular}{|l|l|l|l|l|l|}
\hline Sigma & Erro RMS & Média & $\begin{array}{l}\text { Desvio } \\
\text { Padrão }\end{array}$ & $\begin{array}{l}N^{o} \text { de pon- } \\
\text { tos }\end{array}$ & Correção \\
\hline \hline 3 & 0,004 & $-0,0262$ & 0,0035 & 89 & 1,00004 \\
\hline 4 & 0,003 & $-0,0262$ & 0,0024 & 89 & 1,00008 \\
\hline $5 *$ & 0,003 & $-0,0258$ & 0,0027 & 89 & 1,00012 \\
\hline 6 & 0,003 & $-0,0253$ & 0,0033 & 89 & 1,00017 \\
\hline 7 & 0,004 & $-0,0248$ & 0,0040 & 89 & 1,00023 \\
\hline
\end{tabular}

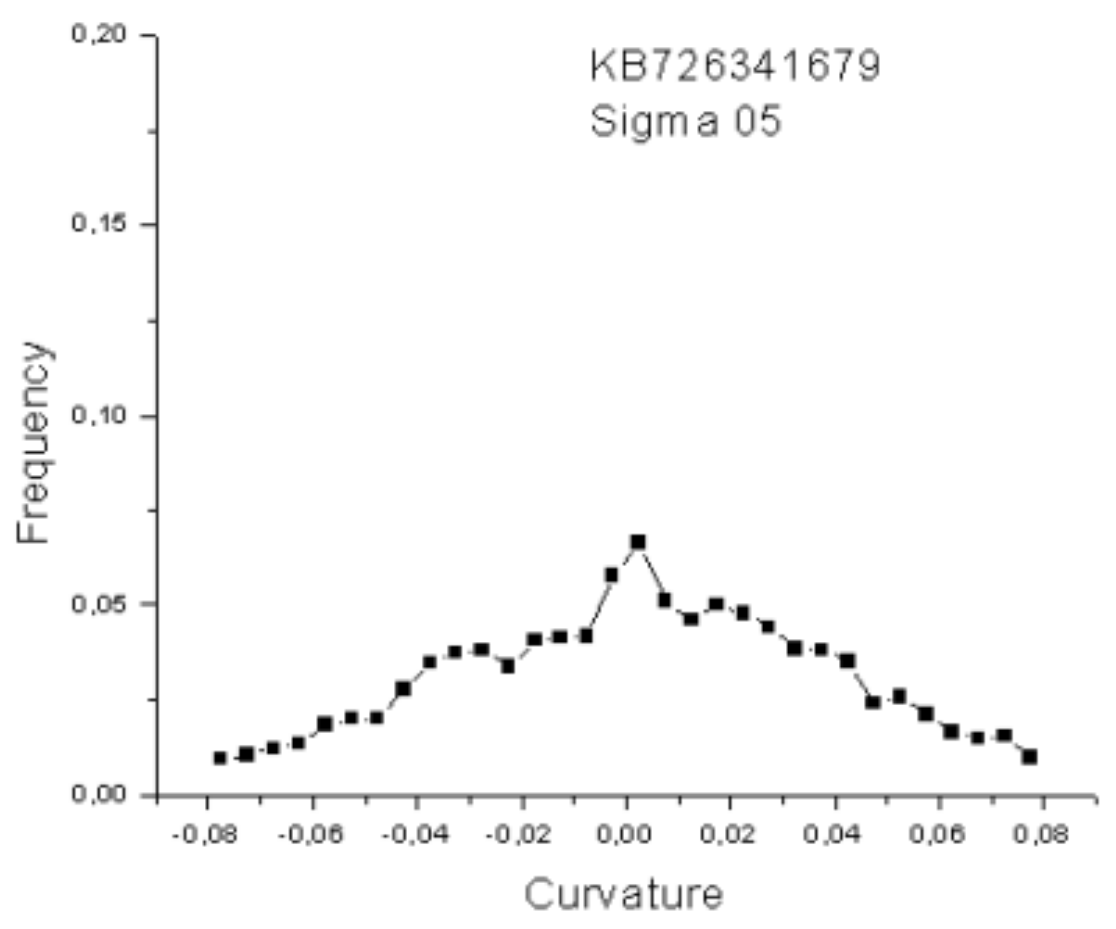

Figura 7.23: Histograma das curvaturas.

mada de Fourier para as derivadas, o resultado da curvatura em cada ponto leva em conta todo sinal. Assim, se houver altas curvaturas próximas de uma região retilínea, isto irá influenciar o resultado neste intervalo. Também, a introdução de um parâmetro de escala no algoritmo, a saber, o sigma da filtragem gaussiana, resulta na interpolação de todo o sinal. 
Tabela 7.3: Raio 60. Curvatura exata $=0,0168$

\begin{tabular}{|l|l|l|l|l|l|}
\hline Sigma & Erro RMS & Média & $\begin{array}{l}\text { Desvio } \\
\text { Padrão }\end{array}$ & $\begin{array}{l}N^{o} \text { de pon- } \\
\text { tos }\end{array}$ & Correção \\
\hline \hline 3 & 0,006 & $-0,0171$ & 0,0060 & 139 & 1,00004 \\
\hline 4 & 0,003 & $-0,0170$ & 0,0031 & 139 & 1,00008 \\
\hline $5 *$ & 0,003 & $-0,0168$ & 0,0026 & 139 & 1,00012 \\
\hline 6 & 0,003 & $-0,0164$ & 0,0029 & 139 & 1,00018 \\
\hline 7 & 0,003 & $-0,0161$ & 0,0034 & 139 & 1,00024 \\
\hline
\end{tabular}

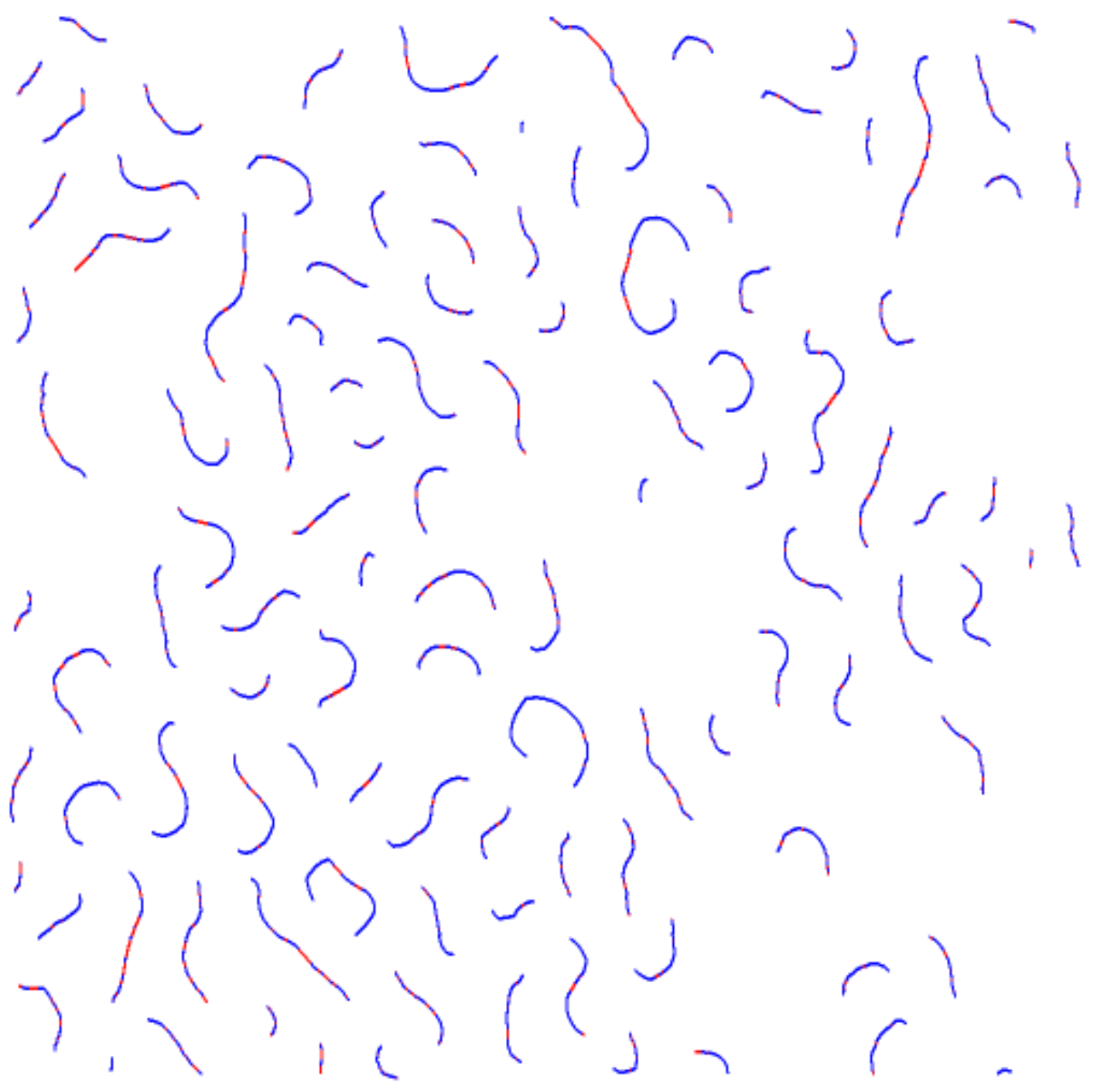

Figura 7.24: Intervalos em vermelho, $(0<k<0.01)$ e em azul, $(k>0.01)$.

Isto significa que as regiões retilíneas foram interpoladas e ajustadas de acordo com a sua vizinhança. Outro fator importante que deve ser levado em consideração é que as extremidades do contorno são regiões de alta curvatura e que tendem a influenciar também no resultado geral. 


\subsection{Parte experimental}

\subsubsection{Materiais}

Uma série de brushes PBA, poli(acrilato de n-butila), figuras 7.25, 7.26, 7.27, 7.28, com diferentes comprimentos da cadeia lateral foi preparada por se enxertar acrilato de n-butila em um macroiniciador [124] poli(metacrilato de 2-(2-bromo propioniloxi)etila), pBPEM, que foi preparado usando a técnica de polimerização radicalar por trasferência atômica (atom transfer radical polimerization, ATRP) [133]. Este método forneceu brushes com um grau de polimerização bem definido da cadeia principal e uma composição uniforme ao longo da backbone. A backbone foi a mesma para todas as quatro brushes com o número médio do grau de polimerização $N=567$. Os graus de polimerização das cadeias laterais PBA foram de $9,27,35$ e 51 respectivamente.

\subsubsection{Caracterização}

A distribuição do peso molecular foi medida através da cromatografia de permeação em gel (GPC) equipada com colunas Waters microstyragel (tamanho do poro $10^{5}, 10^{4}, 10^{3} \AA$ ) e três sistemas de detecção: Um refratômetro diferencial (Modelo Waters 410), laser multiângulo espalhador de luz (MALLS), detector (Wyatt, DAWN EOS), e um viscômetro diferencial (WGE Dr. Bures, h-1001). Veja tabela 7.4 para detalhes.

Tabela 7.4: Pesos moleculares das brushes por MALLS-GPC.

\begin{tabular}{|c|c|c|c|}
\hline$n_{n}^{1)}$ & $N_{n}^{2)}$ & $M_{n}^{3)}, 10^{6}$ & $\frac{M_{w}}{M_{n}}$ \\
\hline \hline 9 & 567 & 0,8 & 1,39 \\
\hline 27 & 567 & 1,4 & 1,54 \\
\hline 35 & 567 & 2,4 & 1,39 \\
\hline 51 & 567 & 4,7 & 1,46 \\
\hline
\end{tabular}

Para esta tabela:

1) Grau de polimerização das cadeias laterais.

2) Grau de polimerização da cadeia principal. 
3) Peso molecular.

4) Índice de polidispersividade.

\subsubsection{Preparação das amostras}

Os filmes Langmuir-Blodget foram produzidos usando um KSV 5000 Instrument cheio com água deionizada (Mili-Q). O filme foi transferido para um substrato de mica a uma velocidade de $0.5 \mathrm{~mm} / \mathrm{min}$. Durante a transferência, a pressão foi mantida constante. A razão de transferência de 0.996 (medida separadamente) assegura que a transferência completa das monocamadas da água para mica foi alcançada.

\subsubsection{Microscopia de força atômica}

As imagens de AFM foram obtidas usando-se um Nanoscope IIIa no modo tapping. A conformação de moléculas individuais foi analisada pelo software SPIA.

\subsection{Resultados e discussão}

Uma das partes mais importantes neste estudo é o equilíbrio da conformação molecular. A preparação da amostra irá se confrontar com duas situações contrárias. Por um lado, as cadeias laterais devem ser adsorvidas a fim de produzir uma brush 2D, por outro lado, as cadeias laterais devem também dessorver para se encurvar. A fim de se resolver essa contradição, as moléculas de brush foram primeiro espalhadas na superfície da água e depois comprimidas em um filme monomolecular pela técnica Langmuir-Blodget, a fim de assumirem uma conformação. A subsequente expansão do polímero resultou na readsorção das moléculas e seu espalhamento em uma monocamada. Enquanto que a compressão mecânica foi usada para dessorver as moléculas, a superfície da água facilitou o equilíbrio da conformação planar. Acreditamos que após muitos ciclos de compressão-expansão, o equilíbrio da conformação das moléculas foi alcançado. 
As imagens de AFM das brushes cilíndricas com diferentes comprimentos de cadeias laterais são mostradas nas figuras 7.25, 7.26, 7.27, 7.28. Nestas figuras, a parte (a) corresponde a conformação antes da compressão e na parte (b), depois da expansão. As moléculas são adsorvidas no substrato de mica devido a forte interação entre as cadeias laterais e o substrato. As cadeias laterais também determinam a distância entre as moléculas nessas figuras. Já foi mostrado que esta distância é proporcional ao comprimento médio das cadeias laterais [134]. Esta observação é consistente com a adsorção praticamente total das cadeias laterais.
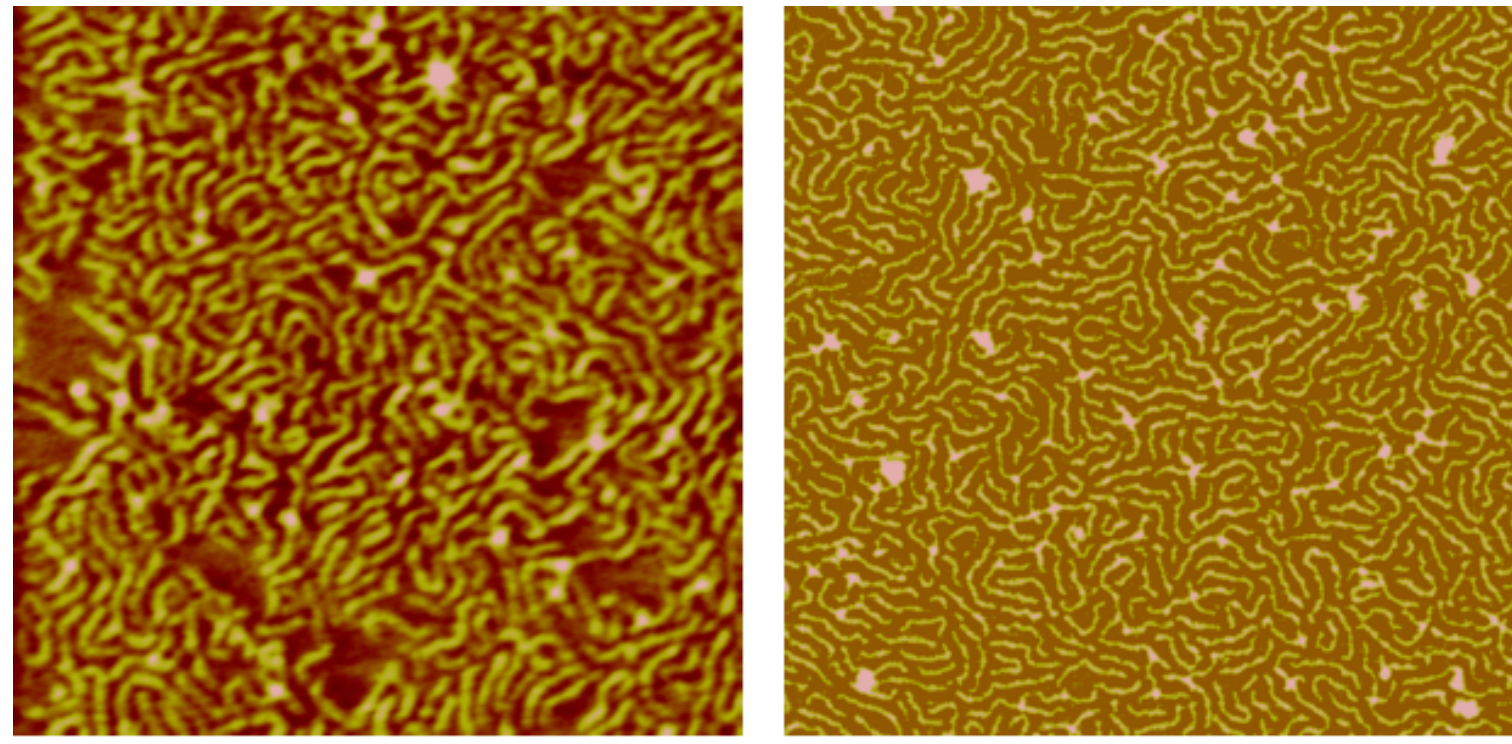

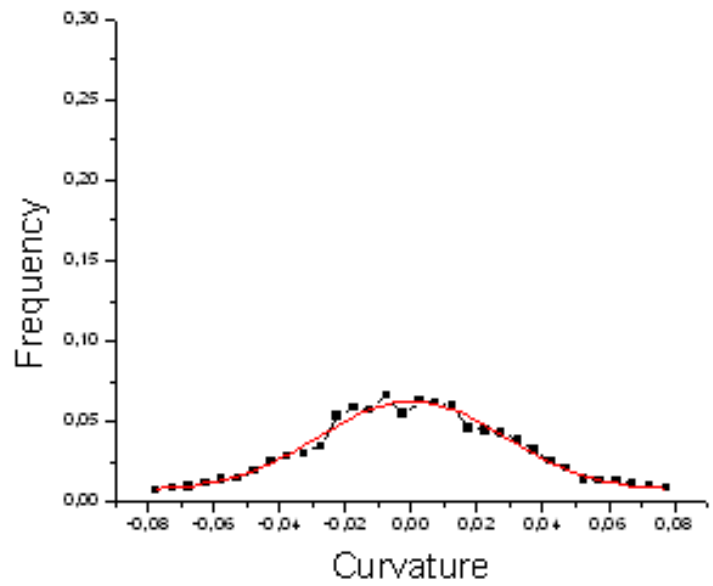

(a)

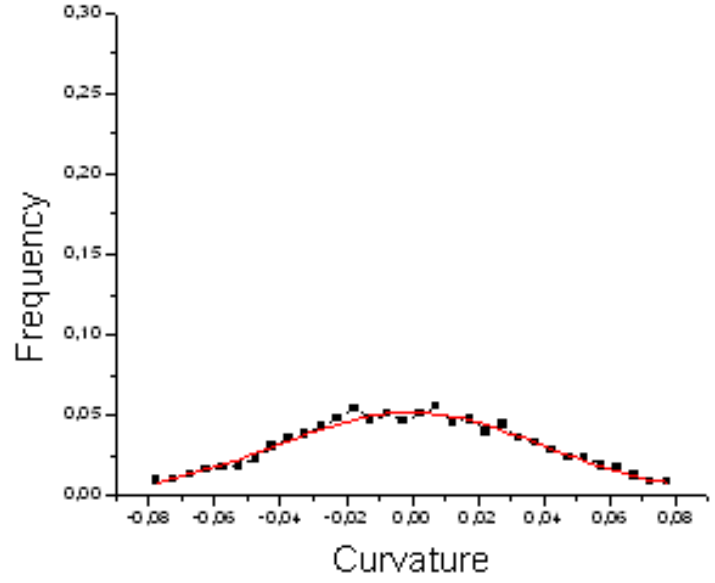

(b)

Figura 7.25: Grau de polimerização = 9. (a) Antes da compressão (b) Após a expansão. Varredura: 1 x $1 \mu \mathrm{m}^{2}$.

Outra observação sobre a curvatura das moléculas adsorvidas. Pode-se observar claramente que as brushes com cadeias laterais menores são mais curvas, 7.25(b) e 7.26(b). 

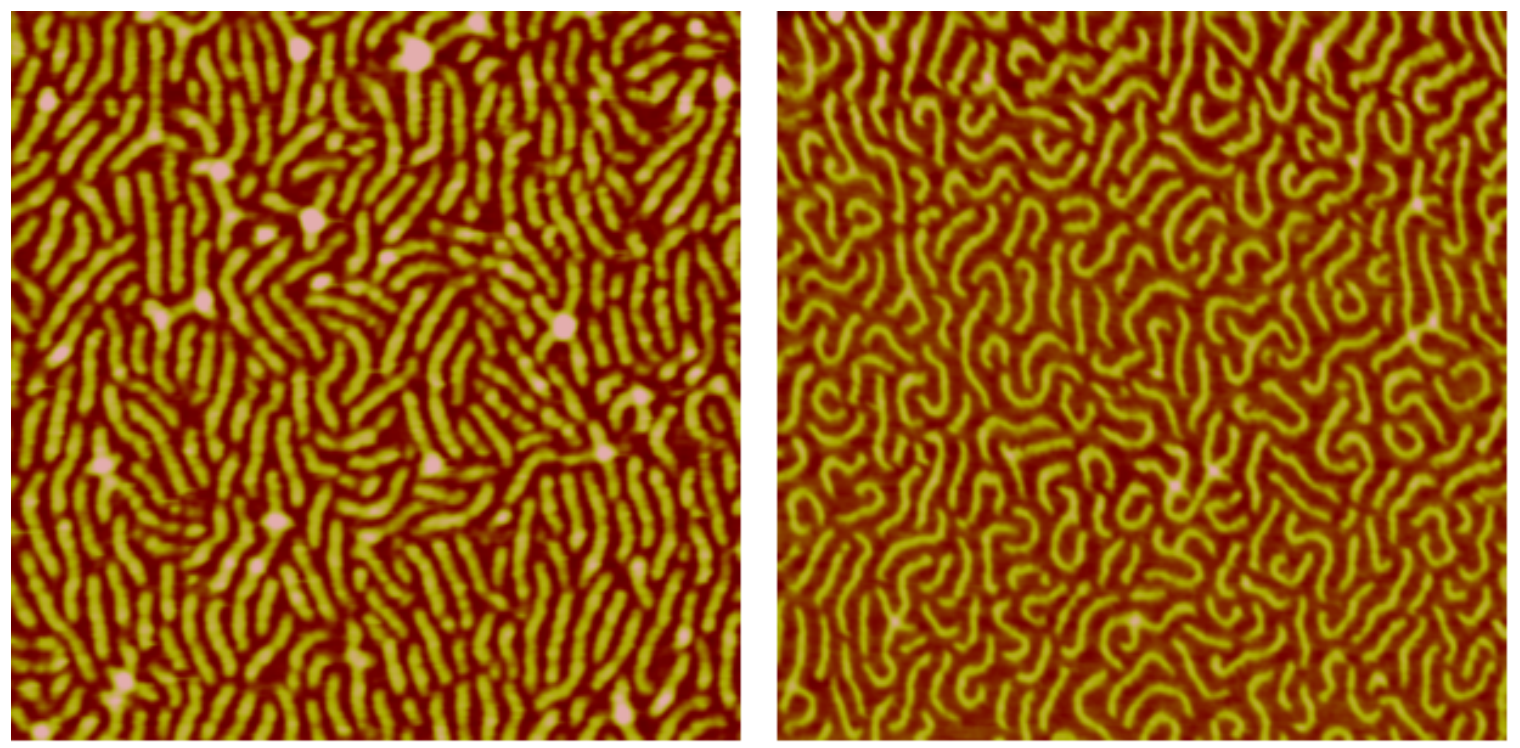

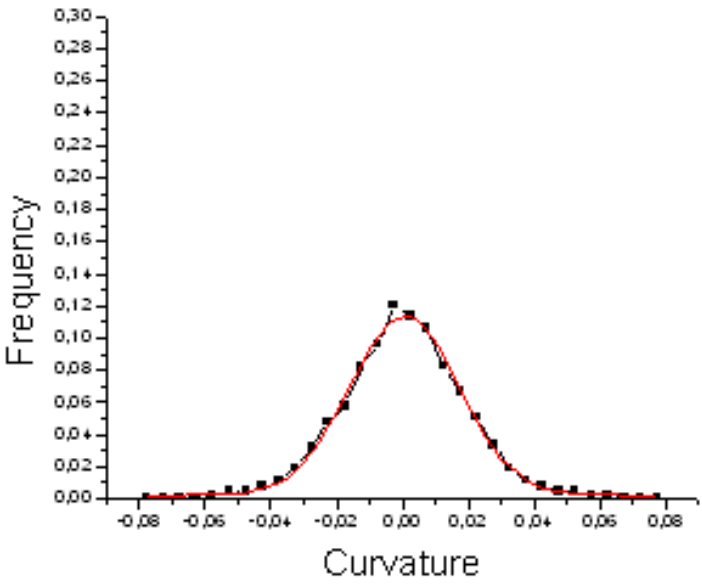

(a)

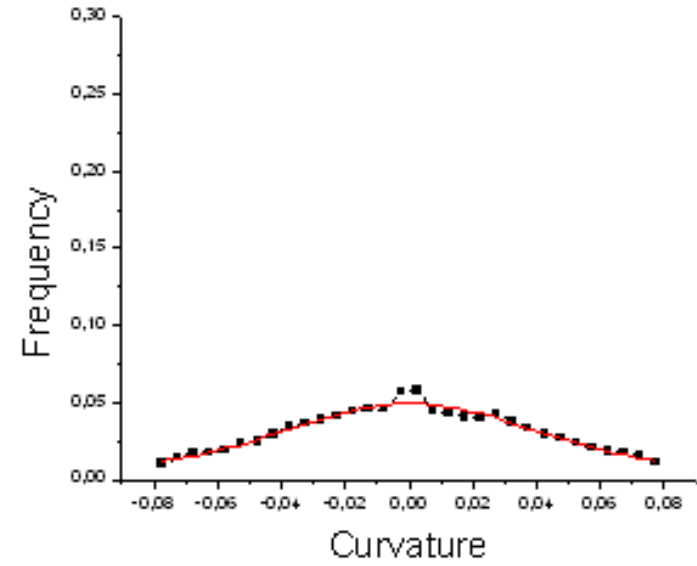

(b)

Figura 7.26: Grau de polimerização = 27. (a) Antes da compressão (b) Após a expansão. Varredura: 1 x $1 \mu \mathrm{m}^{2}$.

No entanto a curvatura se torna menos randômica para brushes com cadeias laterais maiores 7.27(b) e 7.28(b). Em particular, o polímero da figura 7.28 com a cadeia mais longa demonstra a característica de conformação em S e C, esperadas para brushes com estas características.

O software SPIA foi utilizado para determinar a distribuição da curvatura das moléculas. As figuras 7.25, 7.26, 7.27, 7.28 mostram as respectivas distribuições de probabilidade para a curvatura local das brushes, fitadas por uma gaussiana. Para cada polímero, as distribuições, foram medidas para um grande conjunto de moléculas de cerca de 200, para assegurar a 

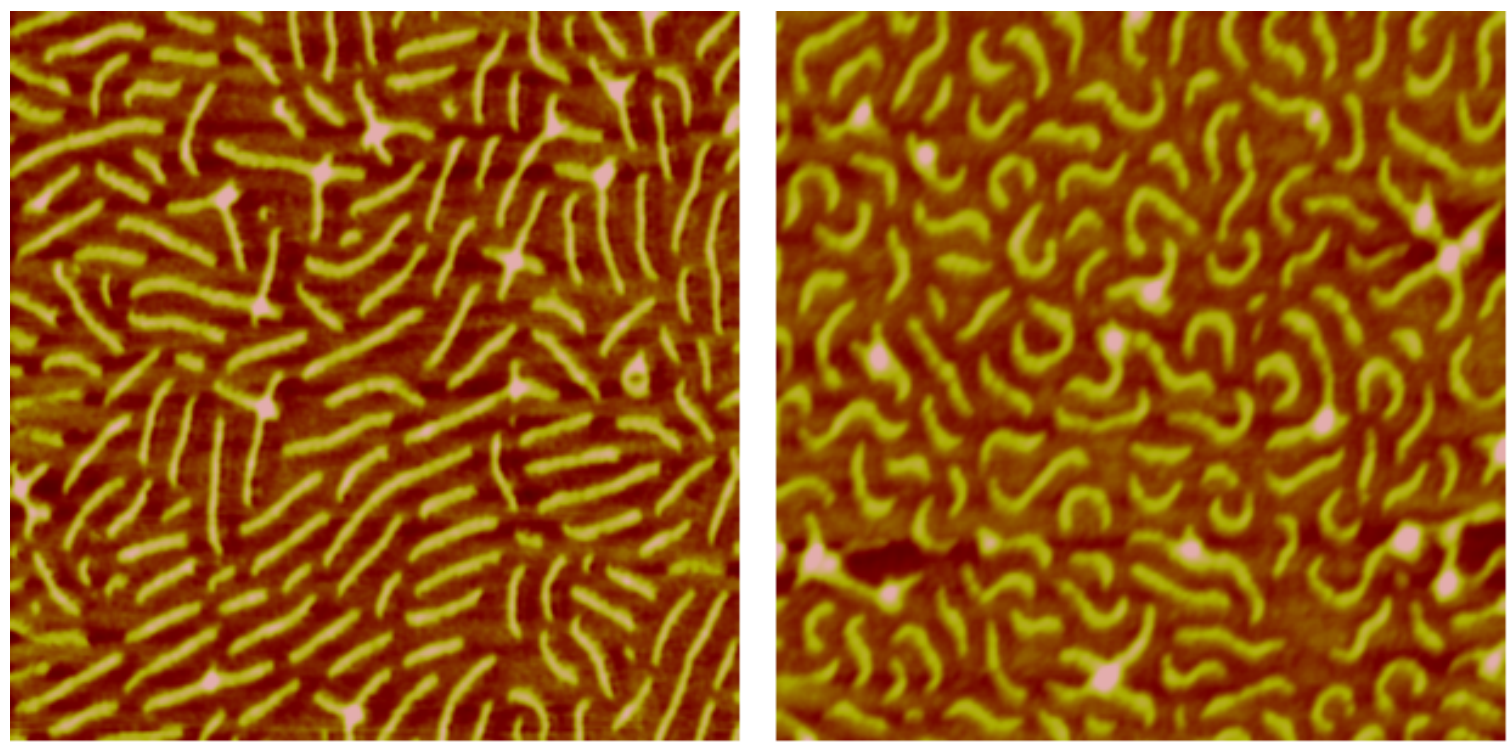

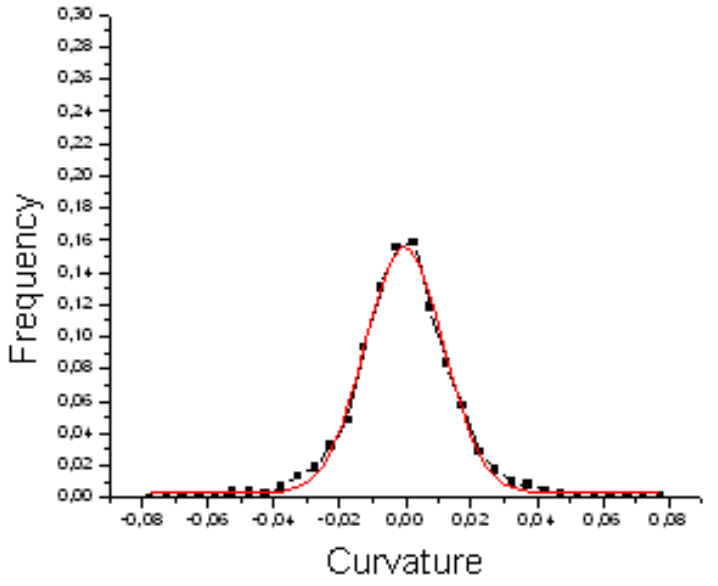

(a)

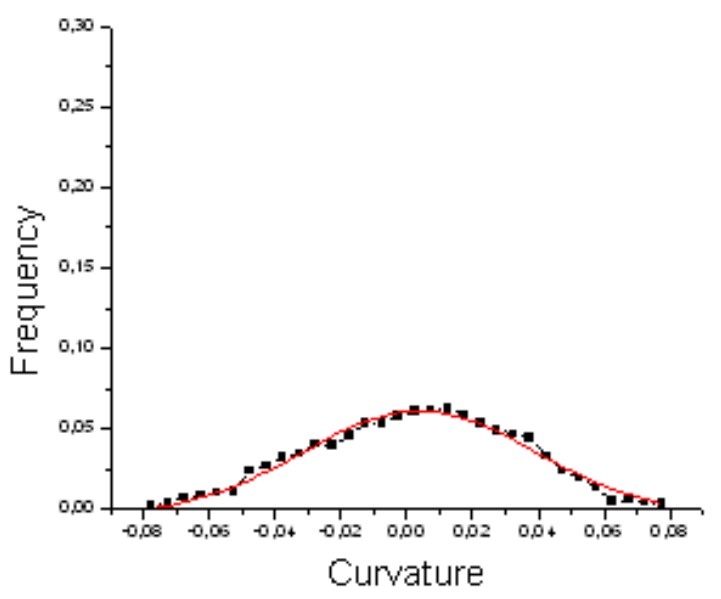

(b)

Figura 7.27: Grau de polimerização $=35$. (a) Antes da compressão (b) Após a expansão. Varredura: $1 \times 1 \mu \mathrm{m}^{2}$.

exatidão estatística.

Analisando as curvaturas vemos que antes e depois da compressão as brushes de menor cadeia lateral possuem uma distribuição maior de curvaturas, com uma quantidade maior de baixas curvaturas, com uma gaussiana de largura 0,079. Isto significa que a conformação deve depender da densidade de enxerto e das frações das cadeias laterais adsorvidas e dessorvidas. Considerando as curvaturas após a expansão, a brush com a maior cadeia lateral mostrou apenas um máximo próximo de zero, que foi consistente com a conformação aproximadamente retilínea da backbone. Além disso, as curvas para as amostras das figuras 7.26 

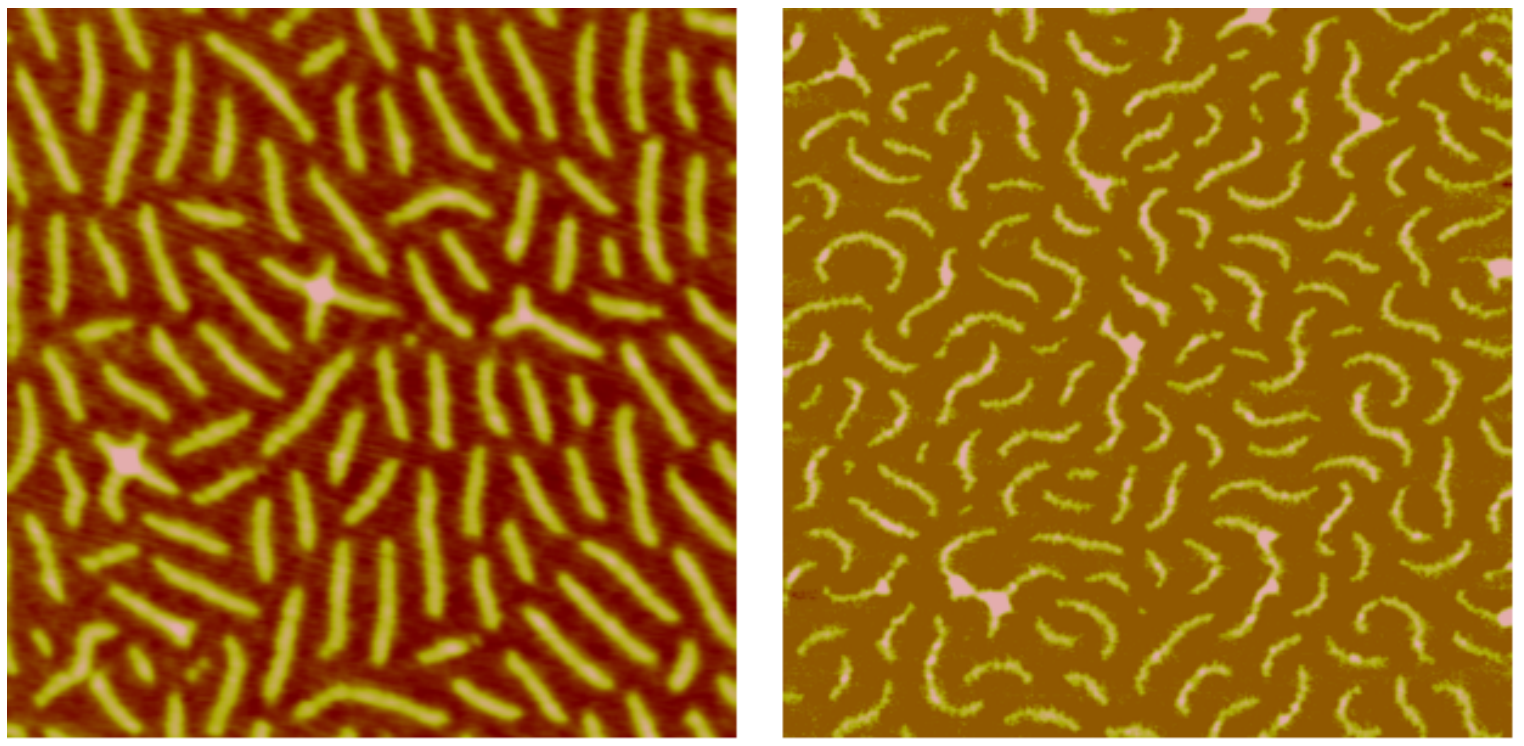

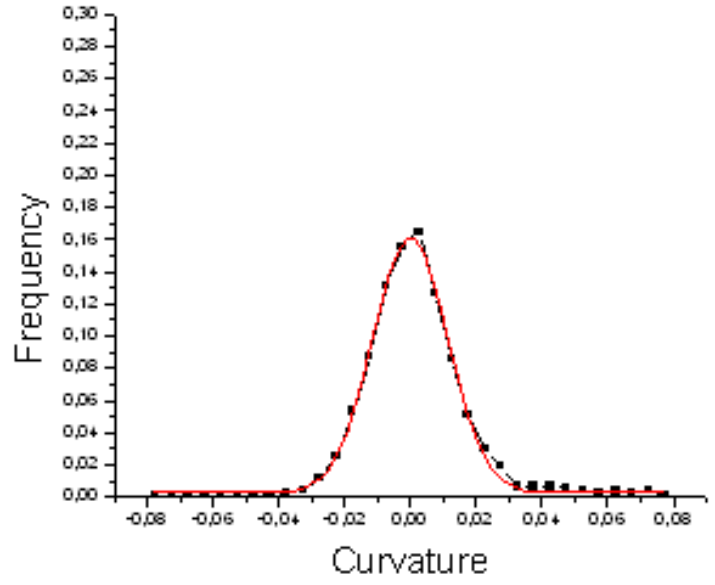

(a)

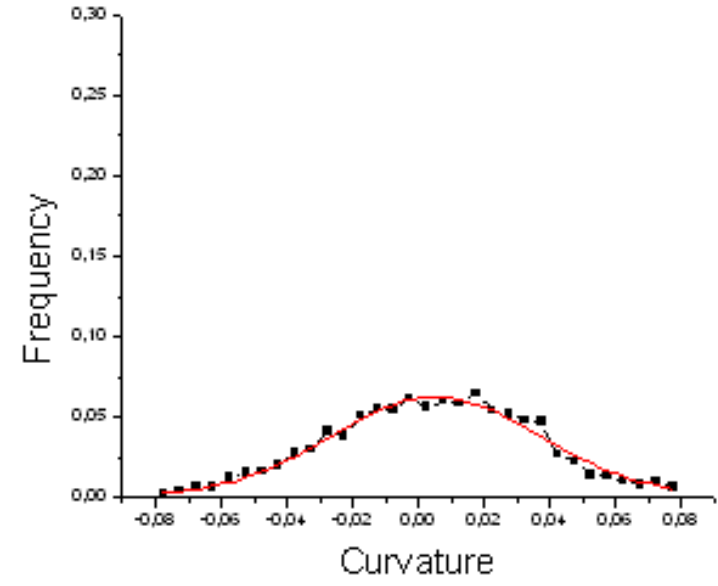

(b)

Figura 7.28: Grau de polimerização $=51$. (a) Antes da compressão (b) Após a expansão. Varredura: $1 \mathrm{x} 1 \mu \mathrm{m}^{2}$.

e 7.27 revelaram uma diminuição na distribuição das curvaturas, com gaussianas de larguras 0, 074 e 0,070 respectivamente. A altura da gaussiana aumenta com o comprimento das cadeias laterais, enquanto que sua largura diminui. A amostra da figura 7.28 com a cadeia mais longa obteve a distribuição de curvaturas menor, com largura da gaussiana 0, 063. Portanto, as brushes demonstram coexistência de duas conformações:

1. Aproximadamente retilínea com curvaturas próximas de zero;

2. conformação com curvatura espontânea. 
Tabela 7.5: Largura da gaussiana.

\begin{tabular}{|c|c|c|}
\hline Grau de polimerização & Antes da compressão & Depois da expansão \\
\hline \hline 09 & 0,05 & 0,08 \\
\hline 27 & 0,03 & 0,08 \\
\hline 35 & 0,02 & 0,07 \\
\hline 51 & 0,02 & 0,06 \\
\hline
\end{tabular}

As larguras das distribuições das curvaturas estão resumidas na tabela 7.5. Em contradição à previsão teórica [125], a distribuição de curvaturas diminuiu com o aumento do comprimento da cadeia lateral.

\subsection{Conclusão}

A curvatura espontânea de brushes em um substrato plano foi investigada por microscopia de força atômica. $\mathrm{O}$ método permitiu a visualização de moléculas individuais e a análise quantitativa de sua conformação. As brushes com cadeias laterais longas $(n=51)$ revelaram conformações com uma distribuição mais estreita de curvaturas. Em contraste, brushes com cadeia lateral menor, $(n=9)$, demonstrou ter uma distribuição mais larga de curvaturas. Esta conformação seria típica para uma conformação aleatória. Para brushes com comprimento intermediário em relação às outras, o AFM permitiu visualizar a coexistência das duas conformações mencionadas aqui. A existência das duas conformações, altas e baixas curvaturas, estão de acordo com a previsão teórica [125]. No entanto, a diminuição da distribuição da curvatura com o aumento do comprimento da cadeia lateral é uma aparente contradição com a teoria. A contradição é explicada pela repulsão estérica das cadeias laterais com alto grau de polimerização [134]. A restrição surge em escalas maiores da cadeia lateral que não foi considerada na teoria. A teoria atual considera somente a curvatura local e não leva em conta interações de longo alcance entre os segmentos das moléculas separados por grandes distâncias ao longo da backbone. O resultado deste trabalho foi publicado em [135]. 


\section{Capítulo 8}

\section{Conclusão e comentários finais}

\subsection{Introdução}

Este capítulo traz comentários finais sobre os trabalhos desenvolvidos e contribuições desta tese em processamento de imagens de polímeros e perspectivas de desenvolvimentos futuros nesta área. Tem por objetivo ressaltar a importância da integração do Processamento de Imagens em imagens de AFM de Polímeros.

\subsection{Conclusões}

Os três capítulos iniciais foram dedicados a chamar a atenção para a aplicação das técnicas de Processamento de Imagens em imagens de Polímeros, como uma integração interdisciplinar com um futuro bastante promissor. Isto se dá pelo fato de que as imagens de Polímeros requerem algoritmos sofisticados de processamento para que se possa obter o máximo de informação destas imagens. Apesar de que tal integração ainda é rara, no Instituto de Física de São Carlos esta colaboração já existe e agora está se estendendo para outros Institutos e Universidades.

O capítulo 2 trouxe uma breve descrição do princípio de funcionamento do AFM. No entanto o objetivo principal foi o de destacar os aspectos críticos da captação das imagens devido a não linearidade do scanner e a interação da sonda com a amostra, que podem introduzir até mesmo grandes distorções em alguns casos, se certos cuidados não forem 
tomados. Estas informações são de fundamental importância para aqueles que trabalharão com o processamento dessas imagens. Com respeito aos modos de operação, o modo tapping mostrou-se o mais apropriado para a captação de imagens de polímeros, por praticamente não danificar a amostra.

O capítulo 3 descreveu o desenvolvimento de softwares específicos para o processamento de imagens de AFM. Observou-se na literatura que diversos grupos de pesquisa tem procurado soluções específicas para seus problemas de análise de imagens, corroborando a necessidade de tal interação. O filtro da mediana é considerado o melhor filtro para um préprocessamento das imagens $[43,114]$. Outros grupos cientes das limitações impostas pelo processo de captação, tem se dedicado no desenvolvimento de softwares específicos para a correção das distorções e compensação da dilatação morfológica provocada pela ponta. Existem alguns freewares que podem ser bastante úteis para quem não quer ficar dependente somente do que acompanha o Nanoscope, tal como o WSxM. Por outro lado, os softwares com mais recursos são pagos, e dentre esses destaca-se o SPIP, o que possui mais recursos tanto de processamento como de análise de imagens. No caso das imagens tratadas nesta tese, as correções foram feitas no software do sistema Nanoscope, que foram satisfatórias para as nossas aplicações.

O capítulo 4 trouxe um estudo de superfícies para o alinhamento de cristais líquidos. Foi desenvolvido um algoritmo para a determinação da orientação principal dos canais produzidos através da matriz de covariância das coordenadas dos pixels dos canais. A orientação medida mostrou estar de acordo com o aparato experimental montado com esta finalidade. As orientações internas dos canais foram obtidas através do operador Sobel que obtém a orientação do gradiente em cada um dos pixels ao longo dos canais. A análise feita através destas ferramentas demonstraram que o Teflon apresentou o relevo mais regular, com canais bem definidos na direção da deposição, enquanto que o PVA apresenta a superfície menos rugosa. As análises de textura mostraram que a superfície de PVA apresentou a orientação mais homogênea. Observou-se também que com o aumento das irregularidades 
ao longo dos canais após o processo de esfregamento das superfícies de PMMA, a energia de ancoramento aumentou. Isto se deu pela formação de cargas na superfície devido ao esfregamento [80]. Concluiu-se que a formação de canais não é o fator mais relevante para a energia de ancoramento dos cristais líquidos, outros fatores como interações moleculares (essas interações dependem da composição química dos materiais) entre o cristal líquido e a superfície a formação de cargas devido ao processo de esfregamento são dominantes no caso do PMMA. No caso do PVA não existem cargas induzidas por esfregamento e por este motivo a sua energia de ancoramento é devido somente às interações moleculares.

A caracterização da morfologia de filmes LBL POMA/PVS foi feita no capítulo 5, através da contagem de domínios globulares contidos nas imagens e da estimativa de seus raios. Foi desenvolvido um algoritmo baseado no conceito dos máximos regionais [93]. A partir da identificação da posição dos domínios, ondas propagantes através do algoritmo das dilatações exatas [6] particionou a imagem em um diagrama de Voronoi. Estes particionamentos coincidiram com as áreas dos domínios, podendo-se determinar a área e o seu raio correspondente. Esta ferramenta de contagem e estimativa da polidispersividade dos raios pode ser aplicada em outras imagens para o mesmo tipo de caracterização, demonstrando ser bastante versátil e útil na análise de imagens de polímeros e de outros materiais. Os resultados do trabalho mostraram que o tamanho dos domínios aumentou com a concentração da solução de POMA, usada na adsorção. Um aumento de quatro vezes nos raios dos domínios levou a uma diminuição de 20 vezes o número de domínios. Atribui-se isso ao aumento da interação polímero-polímero em altas concentrações.

No capítulo 6 foi feita a análise do aumento da fotoluminescência em filmes PPV. Os resultados constituem em mais um exemplo de como a simples análise visual não é suficiente para captar todos os detalhes importantes contidos na morfologia dos filmes. Através de histogramas das alturas dos pontos da imagem, contagem de picos e histogramas das distâncias entre picos conclui-se que a superfície não foi afetada significativamente pela irradiação ao laser e que pode ser usada para se depositar eletrodos metálicos na fabricação de dispositi- 
vos poliméricos emissores de luz. Uma aplicação desenvolvida para esse fenômeno foi uma grade de difração. O padrão periódico existente na superfície do filme foi medido através de um algoritmo de filtragem através da Transformada de Fourier. Este filtro é passa banda, permitindo que o usuário selecione ou remova determinado conjunto de frequências contidos no espectro de potência da imagem. A pequena diferença em altura pico-vale na superfície indica que a grade não foi criada na superfície, mas sim no volume, de acordo com evidências já conhecidas relacionadas com o aumento de PL [111].

O capítulo 7 apresentou um estudo da curvatura espontânea de brushes moleculares depositadas em substratos de mica, após sofrerem compressão pela técnica Langmuir-Blodget. Foram analisadas imagens de brushes com diferentes cadeias laterais, longas, curtas e intermediárias. Asbrushes com cadeias laterais mais curtas apresentaram uma distribuição de curvaturas mais larga, típica de uma conformação aleatória. Para brushes com cadeia lateral de comprimento intermediário e menor, observou-se a coexistência de duas conformações, retilíneas e encurvadas. Por sua vez, a curvatura ao longo das brushes variou bastante, resultando numa distribuição gaussiana mais larga. A existência das duas conformações, curvaturas altas e baixas estão de acordo com a previsão teórica[125]. No entanto, a diminuição da distribuição da curvatura com o aumento do comprimento da cadeia lateral é uma aparente contradição com a teoria. A contradição é explicada pela repulsão estérica das cadeias laterais com alto grau de polimerização [134]. A restrição surge em escalas maiores da cadeia lateral que não foi considerada na teoria. A teoria atual considera somente a curvatura local e não leva em conta interações de longo alcance entre os segmentos das moléculas separados por grandes distâncias ao longo da backbone. Para a extração da curvatura foram adotados os algoritmos contour following para extração do contorno, esqueletização através das dilatações exatas e curvatura pelo método da derivada por Fourier. Estes algoritmos vem sendo usados em diversas aplicações desenvolvidas pelo grupo de Visão Cibernética do Instituto de São Carlos e os resultados obtidos neste trabalho também são bastante satisfatórios como atestam os diversos testes realizados. 


\subsection{Contribuições da tese e desenvolvimentos futuros}

As contribuições da tese concentram-se na aplicação de soluções originais em problemas de imagens de AFM de polímeros. Técnicas tais como esqueletização através das dilatações exatas, curvatura através da derivada por Fourier, máximos regionais foram aplicadas nessas imagens pela primeira vez. Também é importante ressaltar que os problemas propostos obtiveram uma solução específica em cada caso. O método do cálculo da curvatura da backbone através do contorno foi original e poderá ser aplicado em outros casos semelhantes. Do mesmo modo a contagem de domínios e suas respectivas áreas possui inúmeras aplicações.

Uma das maiores contribuições está no software SPIA que reúne todos as funções e algoritmos desenvolvidos. Este software será de grande utilidade para a continuidade da pesquisa e também para outros grupos interessados em manter colaborações conosco, tanto neste Instituto como em outros.

Há diversas perspectivas e desenvolvimentos futuros. Dentre estas podemos citar :

1. Pretende-se desenvolver outros métodos de análise de morfologia de superfícies incluindo Fractal 3D pelo método da salsicha de Minkowski. Este método é importante para se estudar a evolução da superfície sob várias escalas e se aplica particularmente às imagens de AFM por se tratar de imagens de alturas.

2. Caracterização de textura e composição espectral por transformada de Fourier. A caracterização de texturas em imagens possui diversas aplicações, como segmentação de imagens baseada em regiões de textura homogênea. Métodos de análise de frequência local poderão ser úteis, pois a textura pode ser encarada como uma região em que determinado padrão se repete periodicamente.

3. Aplicação das técnicas desenvolvidas em outras imagens de microscopia além de AFM.

4. Métodos de segmentação e identificação de orientações por transformada de Hough. 
5. Segmentação por Watersheds.

6. Desenvolvimento de técnicas de mineração de dados, envolvendo simulated annealing e algoritmos genéticos, para a identificação de tendências e propriedades, caracterizando os diversos tipos de imagens.

7. Inclusão no SPIA de algoritmos para a correção da distorção introduzida pela sonda do AFM. 


\section{Bibliografia}

[1] BINNIG, G.; ROHRER, H. The scanning tunneling microscope. Sci. Am., 253, 40, 1985.

[2] BINNIG, G.; QUATE, C. F.; GERBER, C. Atomic Force Microscope. Phys. Rev. Lett., 56, 930, 1986.

[3] GONZALES, R. C.; WOODS, R. E. Digital Image Processing. Addison-Wesley, 1993.

[4] CASTLEMAN, K. R.; Digital Image Processing. Prentice Hall, Englewood Cliffs, N. J., 1979.

[5] SCHALKOFF, R. J. Digital Image Processing and Computer Vision, John Wiley \& Sons, New York, 1989.

[6] COSTA, L. F.; CESAR JR., R. M. Shape Analysis and Classification. CRC Press, 2001.

[7] RUSS, J. C. Computer-Assisted Microscopy, Plenum Press, New York, 1990.

[8] RUSS, J. C. The Image Processing Handbook, CRC Press, 1995.

[9] WICKRAMASINGHE, H. K. Scanned-probe microscopes. Sci. Am., 260, 98, 1989.

[10] HANSMA, P. K.; RUGAR, D. Atomic force microscopy. Physics Today, 10, 23, 1990.

[11] BINNIG, G.; ROHRER, H.; GERBER, C. WEIBEL, E. 7x7 Reconstruction on Si (111) Resolved in Real Space, Phys. Rev. Lett. 50, 120, 1983.

[12] HANSMA, P. K. et al. STM and ATM: Application to Biology and Technology, Science, 242, 209, 1988.

[13] LI, M. Q. Scanning probe microscopy (STM/AFM) and applications in biology. Appl. Phys. A, 68, 255, 1999.

[14] BINNIG, G.; ROHRER, H. In touch with atoms, Rev. Mod. Phys., 71, S234, 1999.

[15] BINNIG, G.; ROHRER, H. STM - from birth to adolescence, Rev. Mod. Phys., 59, 615, 1987.

[16] PRATER, C. B.; BUTT, H. J; HANSMA, P. K. Atomic force microscopy. Nature, 345, 839, 1990. 
[17] GOULD, S. A. C. et al, The atomic force microscope: a tool for science and industry. Ultramicroscopy, 33, 93, 1990.

[18] HOWLAND, R.; BENATAR, L. A Pratical Guide to Scanning Probe Microscopy. Park Scientific Instruments, 1996.

[19] MAGONOV, S. N.; WHANGBO, M.-H. Surface Analysis with STM and AFM, New York, VCH, publishers, 1996.

[20] AMER, N. H.; MEYER, G. Novel optical approach to atomic force microscopy. Appl. Phys. Lett., 53, 1045, 1988.

[21] GUSTAFSSON, M. G. L.; CLARKE, J. Scanning force microscope springs optimized for optical-beam deflection and with tips made by controlled fracture. J. Appl. Phys., 76, 172, 1994.

[22] MARTIN, Y.; WILLIAMS, C. C.; WICKRAMASINGHE, H. K. Atomic force microscope - force mapping and profiling on a sub 100- scale. J. Appl. Phys., 61, 4723, 1989.

[23] CHEN, X. et al; Interpretation of tapping mode atomic microscopy data using amplitude-phase-distance measurements. Ultramicroscopy, 75, 171, 1998.

[24] ZHONG, Q.; INNIS, D.; KJOLLER, K.; ELING, V. B. Fractured polymer/silica fiber surface studied by tapping mode atomic force microscopy. Surf. Sci. Lett., 290, L688, 1993.

[25] WAWKUSCHEWSKI, A.; CRAMER, K.; CANTOW, H.-J.; MAGONOV, S. N. Optimization of experiment in scanning force microscopy of polymers. Ultramicroscopy, 58, $185,1995$.

[26] BINNIG, G.; SMITH, D. P. E. Single-tube three-dimensional scanner for scanning tunneling microscopy. Rev. Sci. Instrum., 57, 1688, 1986.

[27] BARRETT, R. C.; QUATE, C. F. Optical scan-correction applied to atomic force microscopy. Rev. Sci. Instrum., 62, (6), 1393, 1991.

[28] Scanning Probe Microscopy Training Notebook, Digital Instruments.

[29] EDWARDS, H. et al. Influence of data analysis and other factors on the short-term stability of vertical scanning-probe microscope calibration measurements. J. Vac. Sci. Technol. B, 16, (2), 633, 1998.

[30] EDWARDS, H.; McGLOTHILIN, R.; ELISA, U. Vertical metrology using scanningprobe microscopes: imaging distortions and measurement repeatability. J. Appl. Phys., 83, (8), 3951, 1998.

[31] GRIFFITH, J. E.; GRIGG, D. A. Dimensional metrology with scanning probe microscopes. J. Appl. Phys., 74, R83, 1993.

[32] ALBRECHT, T. R.; AKAMINE, S. CARVER, T. E.; QUATE, C. F. Microfabrication of cantilever styli for the atomic force microscope. J. Vac. Sci. Technol. A, 8, 3386, 1991. 
[33] OHNESORGE, F.; BINNIG, G. True atomic-resolution by atomic force microscopy through repulsive and attractive forces. Science, 260, 1451, 1993.

[34] GRIFFITH, J. E. et al. Scanning probe metrology. J. Vac. Sci. Technol. A, 10, 674, 1992.

[35] MAGONOV, S. N.; RENECKER, D. H. Characterization of polymer surfaces with atomic force microscopy. Ann. Rev. Mat. Sci., 27, 175, 1997.

[36] ALBRECHT, T. R. et al. Imaging and modification of polymers by scanning tunneling and atomic force microscopy. J. Appl. Phys., 64, 1178, 1988.

[37] JIANG, H.; ADAMS, W. W.; EBY, R. K. High performance polymer fibers. in: THOMAS, E. L. (Ed), Structure and properties of polymers. VCH, Weinheim, 1993. v. 12, p.597.

[38] PETERLIN, A. Drawing and annealing of fibrous material. J. Appl. Phys., 48, 4099, 1977.

[39] MAGONOV, S. N.; SHEIKO, S. S.; DEBLIECK, R. A. C.; MOLLER, M. Atomic-force microscopy of gel-drawn ultrahigh-molecular-weight polyethylene. Macromolecules, 26, 6, 1993

[40] SNETIVY, D.; VANCSO, G. J.; RUTLEDGE, G. C. Atomic force microscopy of polymer crystals. 6. Molecular imaging and study of polymorphism in poly(pphenyleneterephthalamide) fibers. Macromolecules, 25, 25, 1992.

[41] VILARRUBIA, J. S. Algorithms for scanned probe microscope image simulation, surface reconstruction, and tip estimation. J. Res. Natl. Inst. Stand. Technol., 102, 425, 1997.

[42] JORGENSEN, J. F. et. al. Hysteresis correction of scanning tunneling microscope images. J. Vac. Sci. Technol. B, 12, (3), 1702, 1994.

[43] WILLIAMS, P. M. et al. Toward true surface recovery: studying distortions in scanning probe microscopy image data. Langmuir, 12, 3468, 1996.

[44] TEGENFELDT, J. O.; MONTELIUS, L. Image widening not only a question of tip sample convolution. Appl. Phys. Lett., 66, (9), 1068, 1995.

[45] REISS, G., SCHNEIDER, F.; VANCEA, J.; HOFFMANN, H. Scanning tunneling microscopy on rough surfaces: deconvolution of constant current images. Appl. Phys. Lett., 57, (9), 867, 1990.

[46] VESENKA, J.; MILLER, R.; HENDERSON, E. Three-dimensional probe reconstruction for atomic force microscopy. Rev. Sci. Instrum., 65, (7), 2249, 1994.

[47] KELLER, D. J.; FRANKE, F. S. Envelope reconstruction of probe microscope images. Surf. Sci., 294, 409, 1993.

[48] MARKIEWICZ, P.; GOH, M. C. Atomic force microscopy probe tip visualization and improvement of images using a simple deconvolution procedure. Langmuir, 10, $5,1994$. 
[49] WILSON, D. L.; KUMP, K. S.; EPPELL, S. J.; MARCHANT, R. E. Morphological restoration of atomic force microscopy images. langmuir, 11, 265, 1995.

[50] VILARRUBIA, J. S. Morphological estimation of tip geometry for scanned probe microscopy. Surf. Sci., 321, 287, 1994.

[51] WILLIAMS, P. M. et al. Blind reconstruction of scanning probe image data. J. Vac. Sci. Technol. B, 14, (2), 1557, 1996.

[52] DONGMO, L. S. et al. Blind restoration method of scanning tunneling and atomic force microscopy images. J. Vac. Sci. Technol. B, 14, (2), 1552, 1996.

[53] VILARRUBIA, J. S. Scanned probe microscope tip characterization without calibrated tip characterizers. J. Vac. Sci. Technol. B, 14, (2), 1518, 1996.

[54] VILARRUBIA, J. S. et al. Experimental test of blind tip reconstruction for scanning probe microscopy. Ultramicroscopy, 85, 141, 2000.

[55] NIE, H. -Y.; WALZAK, M. J. ; Mc INTYRE. Use of biaxially oriented polypropylene film for evaluating and cleaning contaminated atomic force microscopy probe tips: an application to blind tip reconstruction. Rev. Sci. Instrum., 73, (11), 3381, 2002.

[56] FANG, Y. et al. Solid-State DNA by atomic force microscopy. Anal. Chem., 70, 10, 2123, 1998.

[57] SPISZ, T. S. et al. Automated sizing of DNA fragments in atomic force microscope images. Med. Bio. Eng. Comput., 36, 667, 1998.

[58] JAK, M. J. J. et al. Automated detection of particles, clusters and islands in scanning probe microscopy images. Surf. Sci., 494, 43, 2001.

[59] DENG, J. et al. Accurate assessment of the roughness exponent of a fracture surface via scanning tunnelling microscopy. J. Phys. D: Appl. Phys. 32, L45, 1999.

[60] JAMITZKY, F. et al. Scaling-index method as an image processing tool in scanningprobe microscopy. Ultramicroscopy, 86, 241, 2001.

[61] WILLIAMS, J. M.; BEEBE JR., T. P. Analysis of fractal surfaces using scanning probe microscopy and multiple-image variography. J. Phys. Chem., 97, 6249, 1993.

[62] SANCHEZ-SEVILLA, A. et al. Accuracy of AFM measurements of the contour length of DNA fragments adsorbed on mica in air and in aqueous buffer. Ultramicroscopy, 92, $151,2002$.

[63] CESAR JR, R. M.; COSTA, L. F. Towards effective planar shape representation with multiscale digital curvature analysis based on signal processing techniques, Pattern Recognition, 29, 1559, 1996.

[64] ROARK, S. E.; SEMIN, D. J.; ROWLEN, K. L. Quantitative evaluation of SERS-active Ag film nanostructure by atomic force microscopy. Anal. Chem., 68, 473, 1996.

[65] BARRET, S. D. Software for scanning microscopy. Proc. RMS, 37, 3, 167, 2002. 
[66] WILLIAMS, P. M. et al. Biological applications of scanning tunneling microscopy: novel software algorithms for the display, manipulation and interpretation of STM data. Nanotechnology, 2, 172, 1991.

[67] WILLIAMS, P. M. et al. Data analysis using internet: the world wide web scanning probe microscopy data analysis system. Analyst, 122, 1001, 1997.

[68] IGOR, N.; SARTORE, M.; GALLETTI, R. Object-oriented data model for scanning probe microscopy image processing. Image and Vision Computing, 14, 435, 1996.

[69] BOHMIG, S. D.; BRANDL, K. W.; REICHL, B. M.; STORI, H. A multisource image processing enviroment in surface analysis. Fresenius J. Anal. Chem., 353, 609, 1995.

[70] MARKIEWICZ, P.; GOH, M. C. Simulation of atomic force microscope tipsample/sample-tip reconstruction. J. Vac. Sci. Technol. B, 13, (3), 1115, 1995.

[71] RITLEY, K. A.; SCHLESTEIN, M.; DOSCH, H. DataScan: A extensible program for image analysis in Java. Computer Physics Communications, 137, 300, 2001.

[72] BARRET, S. D. et al. The use of macros in AFM image analysis and image processing. J. Comp. Ass. Microsc., 10, 77, 1998.

[73] BICKMORE, B. R. et al. Measuring discrete feature dimensions in atomic force microscopy images with Image SXM. Geo. Mater. Res., 1, 5, 1999.

[74] JEROME, B. Surface effects and anchoring in liquid-crystals. Rep. Prog. Phys., 54, 391, 1991.

[75] OLIVEIRA, E. A.; FIGUEIREDO NETO, A. M.; DURAND, G. Gliding anchoring of lyotropic of nematic liquid crystals on amorphous glass surfaces. Phys. Rev. A, 44, R825, 1991.

[76] VORFLUSEV, V. P.; KITZEROW, H-S.; CHIGRINOV, V. G. Azimutal anchoring energy in photoinduced anisotropic films. Jpn. J. Appl. Phys., 34, L1137, 1994.

[77] BERREMAN, D. W. Solid Surface Shape and the Alignment of an Adjacent Nematic Liquid Crystal. Phys.Rev.Lett., 28, 1683, 1972.

[78] RODRIGUES, C. A., COSTA, L. F. da, FARIA, R. M., SOUZA, N. C., OLIVEIRA JR, O. N., BECHTOLD, I. H., OLIVEIRA, E. A., BONVENT, J. J. Advanced image characterization in scanning probe microscopy. In: XIV BRAZILIAN SYMPOSIUM ON COMPUTER GRAPHICS AND IMAGE PROCESSING (SIBGRAPI-01), Florianópolis, 2001. Proc. of SIBGRAPI 2001, IEEE Computer Society Press. Los Alamitos, California, 2001, 393. (http://computer.org/proceedings/sibgrapi/1330/1330toc.htm, p.393).

[79] MATSUDA H. et al. Estimation of the static eletricity and optical retardation produced by rubbing polyimide and polyamide films with different fabrics. Mol. Cryst. Liq. Cryst., 264, 23, 1995. 
[80] BECHTOLD, I. H. et al. Rubbing-induced charge domains observed by eletrostatic force microscopy: effect on liquid crystal alignment. Liquid Crystals (Taylor \& Francis). aceito, 2003.

[81] RODRIGUES, C. A., BECHTOLD, I. H., COSTA, L. F., BONVENT, J. J., OLIVEIRA, E. A. Image processing of aligning surfaces for liquid crystals. 9th International Topical Meeting on Optics of Liquid Crystals,Napoli, Italy, 2001. (http://www.na.infn.it/olc2001/long_abstracts.htm, abstract $n^{\circ}$ 54).

[82] STEWARD P.A.; HEARN J.; WILKINSON M.C. An overview of polymer latex film formation and properties. Advances in Colloid and Interface Science, 86,(3), 195, 2000.

[83] HO, C. C.; KHEW, M. C. Low Glass Transition Temperature (Tg) Rubber Latex Film Studied by Atomic Force Microscopy. Langmuir, 16, (6), 2436, 2001.

[84] DECHER G.; HONG J. D.; SCHMITT J. Buildup of ultrathin multilayer films by a self-assembly process: III. Consecutively alternating adsorption of anionic and cationic polyelectrolytes on charged surfaces,. Thin Solid Films, 210/211, 831, 1992.

[85] FERREIRA M.; CHEUNG J. H.; RUBNER M. F. Molecular self-assembly of conjugated polyions: a new process for fabricating multilayer thin film heterostructures. Thin Solid Films, 244, 806, 1994.

[86] HAMMOND, P.T. Recent explorations in electrostatic multilayer thin film assembly. Curr. Opin. Colloid Interface Sci., 4, 430, 2000.

[87] DECHER, G. Fuzzy Nanoassemblies: Toward Layered Polymeric Multicomposites. Science, 277, 1232, 1997.

[88] GOH, M. C. et al. Atomic Force Microscopy Studies of Salt Effects on Polyelectrolyte Multilayer Film Morphology. Langmuir, 17, (21), 6655, 2001.

[89] RUBNER, M. F. et al. Fabrication of Microporous Thin Films from Polyelectrolyte Multilayers. Langmuir, 16, 5017, 2000.

[90] OLIVEIRA Jr, O. N. et al. Preparation of parent polyaniline thin films using the selfassembly technique. Synthetic Metals, 101, 726, 1999.

[91] NICOLINI, C. et al.Physical Properties of Polyaniline Films: Assembled by the Layerby-Layer Technique. Langmuir, 15, 1252, 1999.

[92] COSTA, L. F.; ESTROZI, L. F. Multiresolution Shape Representation without Border Shifting. Eletron. Lett., 35, (21), 1829, 1999.

[93] SOILLE, P. Morphological Image Analysis: Principles and Applications, SpringerVerlag, 1999.

[94] COSTA, L. F. Multidimensional scale-space shape analysis. International Workshop on Synthetic-Natural Hibrid Coding and Three Dimensional Imaging, Greece, 1999.

[95] COSTA, L. F.; CAMPOS, A. G.; MANOEL, T. M. An Integrated approach to shape analysis: Results and Perspectives. QCAV2001, France, 2001. p. 23-34. 
[96] COSTA, L. F. Robust Skeletonization through Exact Euclidean Distance Transform and its Application to Neuromorphometry. Real Time Imag., 6, 415, 2000.

[97] FALCÃO, A. X.; COSTA, L. F.; CUNHA, B. S. Multiscale skeletons image foresting transform and its application to neuromorphometry, Patt. Rec., 35, (7), 1571, 2002.

[98] OGNIEVICZ, R. L.; KUBLER, O. Hierarchical voronoi skeletons. Patt. Recog., 28, (3), 343,1995.

[99] OLIVEIRA Jr., O. N. et al. Kinetics of Adsorption of Poly(o-methoxyaniline) SelfAssembled Films. Macromolecules, 30, 6095, 1997.

[100] MATTOSO, L. H. C.; BULHÕES, L. O. S. Synthesis and characterization of poly(oanisidine) films. Synthetic Metals, 52, 171, 1992.

[101] RODRIGUES C. A.; COSTA, L. F.; SOUZA, N. C.; OLIVEIRA Jr., O. N.; SILVA, J. R.; GIACOMETTI, J. A. Adsorption processes in layer-by-layer films of poly(omethoxyaniline): the role of aggregation Thin Solid Films, in press, 2003.

[102] RODRIGUES C. A.; COSTA, L. F.; SOUZA, N. C.; OLIVEIRA Jr., O. N.; SILVA, J. R.; HERNANDES, A. C.; GIACOMETTI, J. A. Diffusion-controlled growth of aggregates in layer-by-layer films of poly(o-methoxyaniline), Synthetic Metals, in press, 2003.

[103] RODRIGUES C. A.; COSTA, L. F.; SOUZA, N. C.; OLIVEIRA Jr., O. N. Statistical characterization of morphological features of layer-by-layer polymer films using image analysis. Journal of Nanoscience and Nanothecnology, in press, 2003.

[104] LI, L., CHAN, C. M., LI, J. X., MG, K. M., YEUNG, K. L., WENG, L. T. A Direct Observation of the Formation of Nuclei and the Development of Lamellae in Polymer Spherulites. Macromolecules, 32, 8240, 1999.

[105] BAR, G., THOMANN, Y., BRANDSCH, R., WHANGBO, M. H. Characterization of the Morphologies and Nanostructures of Blends of Poly(styrene)-blockpoly(ethene-co-but-1-ene)- block-poly(styrene) with Isotactic and Atactic Polypropylenes by Tapping-Mode Atomic Force Microscopy. Langmuir, 14, 1219, 1998.

[106] AKCELRUD, L. Electroluminescent polymers. Prog. Polym. Sci., in press, 2003.

[107] GU, X. et. al. Characterization of polyester degradation using tapping mode atomic force microscopy: exposure to alkaline solution at room temperature. Polymer Degradation and stability, 74, 139, 2001.

[108] CUMPSTON, B. H., JENSEN, K. F. Photo-oxidation of eletroluminescent polymers. TRIP, 4, 151, 1996.

[109] HOLZER, W. et. al. Photodegradation of some luminescent polymers. Chem. Phys., 248, 273, 1999.

[110] BABA, M.; KAKITANI, S.; ISHII, H.; OKUNO, T. Fine atomic image of mica cleavage planes obtained with an atomic force microscope (AFM) and a novel procedure for image processing. Chem. Phys., 221, 23, 1997. 
[111] GOBATO, Y. G. et al. Improvement of photoluminescence efficiency in poly(pphenylene vinylene) induced by laser irradiation. Mol. Cryst. Liq. Cryst., 374, 497, 2002.

[112] GOBATO, Y. G. et al. Photoinduced photoluminescence intensity enhancement in poly(p-phenylene vinylene) films. Appl. Phys. Lett., 81, 942, 2002.

[113] HALLIDAY, D. A. et al. A study on the elimination-reaction of sulfoniumpolyelectrolyte precursor polymers to poly(p-phenylenevinylene. J. Chem. Soc., Chem. Commun., 22, 1685, 1992.

[114] KOKARAM, A. C. et al. Restoration of images from scanning-tunneling microscope. Applied Optics, 34, (23), 5121, 1995.

[115] JIANG, X. L. et al. Polarization dependent recordings of surface relief gratings on azobenzene containing polymer films. Appl. Phys. Lett., 68, 2618, 1996.

[116] LI, X. T.; NATANSOHN, A.; ROCHON P. Photoinduced liquid crystal alignment based on a surface relief grating in an assembled cell. Appl. Phys. Lett. 74, 3791, 1999.

[117] URBAN III, F. K.; ROMINE, P.; ISLAM, Md. S. Advanced image processing in scanning probe microscopy. Thin Solid Films, 253, 318, 1994.

[118] FANG, S. J. et al. Analyzing atomic force microscopy images using spectral methods. J. Appl. Phys., 82, (12), 5891, 1997.

[119] BARFORD, W.; BURSILL, R. J. Theory of molecular excitons in the phenyl-based organic semiconductors. Chem. Phys. Lett., 268, 535, 1997.

[120] CHANDROSS, M. et al. Excitons in poly(para-phenylenevinylene). Phys. Rev. B, 50, $14702,1994$.

[121] RAUCHER, U. et al. Exciton versus band description of the absorption and luminescence spectra in poly(p-phenylenevinylene). Phys. Rev. B, 42, 9830, 1990.

[122] KUMAR, J. et al.Gradient force: The mechanism for surface relief grating formation in azobenzene functionalized polymers. Appl. Phys. Lett., 72, 2096, 1998.

[123] BIAN, S. et al. Photoinduced surface deformations on azobenzene polymer films. $J$. Appl. Phys., 86, (8), 4498, 1999.

[124] SHEIKO, S. S.; PROKHOROVA, S. A.; BEERS, K. L.; MATYJASZEWSKI, K.; POTEMKIN, I.I; KHOKHLOV, A. R.; MOLLER, M. Single molecule rod - globule phase transition for brush molecules at a flat interface. Macromolecules, 34, 8354, 2001.

[125] POTEMKIN, I.I; KHOKHLOV, A.R.; PROKHOROVA, S.; SHEIKO, S.S.; MOLLER, M.; BEERS, K.L.; MATYJASZEWSKI, R.F.; WIGGINS, J.S.; PUCKETT, A.D. Spontaneous curvature of comb-like polymers at a flat interface. submitted to Macromolecules, 2002. 
[126] BLUM, H. A transformation for extracting new descriptors of shape, models for the perception of speech and visual form. Whathen-Dunn, MIT Press, Cambridge, Mass, 1967.

[127] THOMAS JR, G. B. Cálculo. Vol.2, Ao Livro Técnico, Rio de Janeiro, 1968.

[128] BRACEWELL, R. N. The Fourier Transform and its Applications. $2^{\text {nd }}$ ed., McGrawHill, New York, 1986.

[129] COSTA, L. F.; CESAR JR., R. M. The application and assessment of multiscle bending energy for morphometric characterization of neural cells. Rev. Sci. Instr., 68, 2177, 1997.

[130] COSTA, L. F.; CESAR JR., R. M. Piecewise linear segmentation of digital contours in $\mathrm{O}(\mathrm{N} \log (\mathrm{N}))$ through a technique based on effective digital curvature estimation. Real Time Imaging, 1, 409, 1995.

[131] COSTA, L. F.; VELTE, T. J. Automatic characterization and classification of ganglion cells from the salamander retina. J. Comp. Neurol., 404, 33, 1999.

[132] ESTROZI, L. F. et al. 1D and 2D fourier-based approaches to numeric curvature estimation and their comparative performance assessment. Digital Signal Processing, 13, $1,172,2003$.

[133] SHEIKO, S. S.; MOLLER, M. M.; BORNER, H. G.; BEERS, K. ; MATYJASZEWSKI, K. Synthesis of molecular brushes with block copolymer side chains using atom transfer radical polymerization. Macromolecules, 34, 4375, 2001.

[134] SHEIKO, S. S.; MOLLER, M. Visualization of macromolecules - a first step to manipulation and controlled response. Chem. Rev., 101, 4099, 2001.

[135] RODRIGUES, C. A.; SHEIKO, S. S.; PEREIRA-DA-SILVA, M. A.; , SHIRVANIANTS, D. G.; BEERS, K.; MATYJASZEWSKI, K.; POTEMKIN, I. I.; MOLLER, M. Spontaneous curvature of polymer brushes. Polim. Prep. (Am. Chem. Soc., Div. Polym. Chem.), in press. 2003. 


\section{Apêndice A}

\section{O software SPIA}

Este software segue uma estrutura padrão em softwares de processamento de imagens. Foi desenvolvido com uma interface MDI (Multiple Document Interface) onde se pode abrir diversas janelas de uma só vez. A interface pode ser observada na figura A.1.

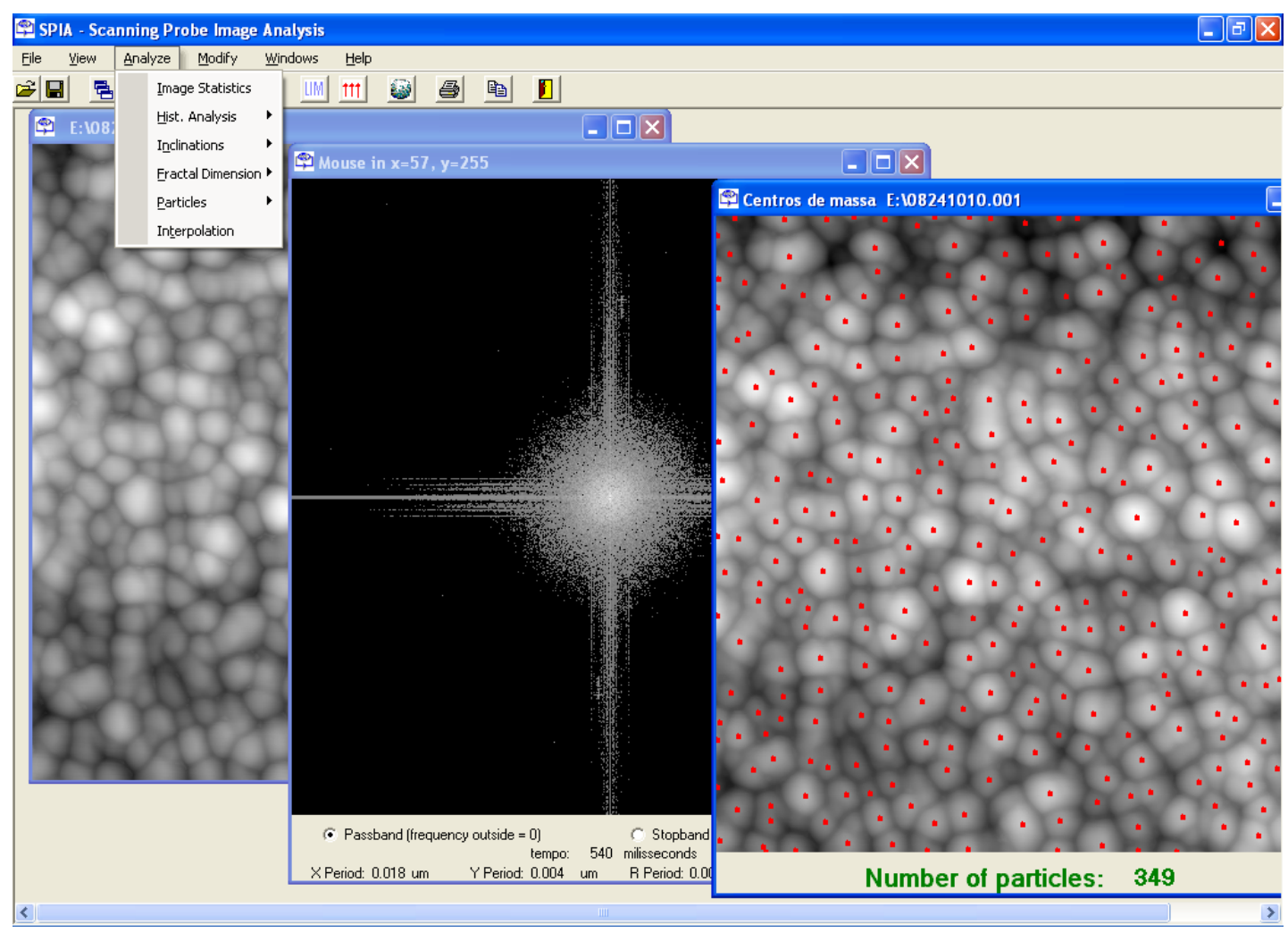

Figura A.1: Interface do SPIA.

As funções estão divididas em vários menus ao longo da barra de ferramentas. Existem também alguns botões de acesso rápido para algumas funções que são utilizadas com mais frequência. A seguir será feita uma descrição das funções contidas nos menus e submenus. 


\section{A.1 Menu File}

Open: Abre imagens nos formatos bmp, pgm, txt (ASCII) e o formato das imagens do software do Nanoscope III da Digital Instruments, versões 4.3x e 4.4x.

New: Cria imagens de teste.

Save: Salva em bmp ou em txt (imagem ou dados, ASCII).

Save As: Escolhe o local onde será salva a imagem em bmp.

Exit: Fecha o software.

\section{A.2 Menu View}

Zoom: O usuário seleciona com o mouse a região da imagem com a tecla Ctrl pressionada, podendo fazer o zoom de $2 \mathrm{x}$ ou $4 \mathrm{x}$.

Stretch: Comprime a imagem para $512 \times 512$.

Line Plot: Escolha de um perfil da imagem.

Threshold: Faz a limiarização automática através do método da menor diferença das entropias.

Quadrant: Seleção de um dos quatro quadrantes da imagem.

Histograms: Escolha do histograma dos tons de cinza da imagem, da imagem equalizada, do filtro sobel e sobel equalizado.

Media: Média de todos os tons de cinza da imagem.

\section{A.3 Menu Analyze}

Image Statistics: Dados estatísticos sobre a imagem, que inclui rugosidade RMS, altura máxima, média, escala da imagem.

Hist. Analysis: Funções para o estudo dos substratos utilizados no alinhamento de cristais líquidos, histograma das alturas na imagem, e histograma das alturas dos picos.

Inclinations: Funções para o estudo das inclinações de domínios na imagem.

Fractal Dimension: Dimensão Fractal 2D pelo método da salsicha de Minkowski.

Particles: Contagem de partículas. O usuário deve entrar com o número de cortes e o limite inferior para os cortes. Estimativa dos raios dos objetos através do diagrama de Voronoi. Análise estatística de cada corte feito na imagem.

Interpolation: Interpola sinal 1D através da série de Fourier. 


\section{A.4 Menu Modify}

Eraser Area: Elimina objetos em imagens binárias com uma quantidade de pixels igual ou menor que um valor definido pelo usuário.

Manual Threshold: Aplica limiar para um valor em nanometros.

Threshold: Aplica limiar definido em tons de cinza.

Skeleton: Extrai o esqueleto de uma ou mais formas em imagens binárias.

Curvature: Extrai curvatura dos contornos de um ou mais objetos contidos na imagem.

Contour Following: Extrai o contorno de um ou mais objetos através do algoritmo de perseguição de contorno.

Morphology: Aplica dilatação ou erosão em esqueletos.

Flip: Inverte a imagem.

Rotate: Gira a imagem.

Make circle: Cria imagem binária de circunferência com raio definido pelo usuário.

Equalization: Aplica equalização na imagem.

Central Component: Centraliza um objeto em imagem binária.

Filters: Filtro da mediana, Sobel, operador cruzado, suavização gaussiana do contorno multiescala.

Density Map: Mapa de densidades após a contagem de objetos.

Contour Perimeter Area: Extração do contorno por análise da vizinhança, perímetro e área do objeto.

Draw in image Escreve linhas brancas para particionar imagens binárias.

Negative Obtém o negativo da imagem.

Circular Border Coloca uma moldura circular branca na imagem.

White Border Coloca uma borda branca ma imagem.

Convolution Convolução da imagem com uma gaussiana ou máscara definida pelo usuário.

\section{A.5 Menu Windows}

Este menu tem diversas opções para ordenação e fechamento das janelas. 


\section{Apêndice B}

\section{Formato do arquivo do Nanoscope III}

\section{B.1 Organização geral do arquivo}

As imagens que são capturadas pelo sistema do AFM, Nanoscope III, são armazenadas como arquivos binários. Há também a opção para que sejam exportados com arquivos ASCII, mas esse procedimento quadruplica o tamanho do arquivo. Dependendo do número de imagens contidas no arquivo (por exemplo, imagem de altura e de fase), e do número de pontos contidos na imagem, o tamanho poderá variar. Por exemplo, para uma varredura de 512x512, o arquivo binário com uma imagem terá $532 \mathrm{~KB}$ e o arquivo salvo todo em ASCII terá cerca de $2000 \mathrm{~kb}$. Independente do tamanho, todos os arquivos incluem :

1. Um cabeçalho contendo vários parâmetros de configuração usados durante a captura da imagem original, uma linha característica para indicar o fim do cabeçalho (Ctrl-Z), dados randômicos (padding data);

2. Os dados da imagem, compreendendo dois bytes $\left(2^{16}\right)$ por pixel.

O cabeçalho é fundamental para a interpretação dos dados, pois provê a informação necessária para a escala em Z,X e Y, etc. e revela exatamente onde começam os dados no arquivo.

Os arquivos contendo duas ou mais imagens contém listas de parâmetros separadas e os dados da imagem, conforme a figura B.1. Um exemplo abreviado de um arquivo com duas imagens é mostrado a seguir (para a versão 4.42):

$\backslash *$ File list

$\backslash$ Version : $0 x 04420004$

$\backslash$ Date : 04 : 03 : 17 PM Tue Nov 091999

$\backslash$ Start context : $O L$

$\backslash$ Data length : 20480 - Tamanho do cabeçalho.

$\bullet$

(até aqui, parâmetros comuns às duas imagens). 

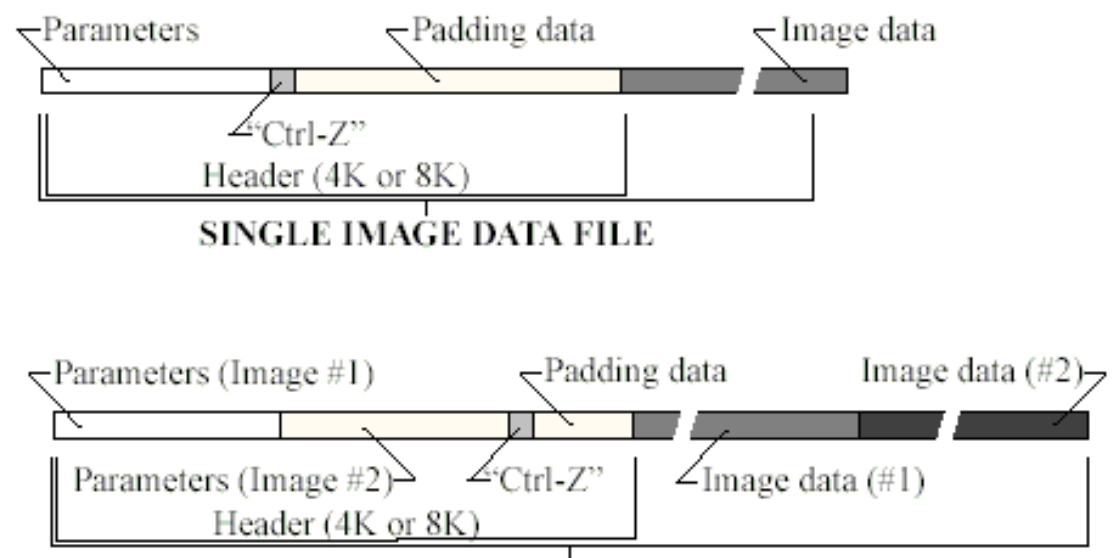

TWO-IMAGE DATA FILE

Figura B.1: Estrutura do arquivo de dados da imagem (Nanoscope Command Reference Manual).

\* Ciao image list - Parâmetros da primeira imagem.

$\backslash$ Data of f set : 20480 - Posição onde começa a primeira imagem.

$\backslash$ Data length : 524288 - Tamanho da primeira imagem, em bytes.

-

\ Ciao image list - Parâmetros da segunda imagem.

$\backslash$ Data of f set : 544768 - Posição onde começa a segunda imagem.

$\backslash$ Data length : 524288 - Tamanho da segunda imagem.

-

$\backslash *$ File list end - Fim dos parâmetros

(a partir daqui, padding e dados binários da imagem).

Dependendo da versão do software do Nanoscope, a lista de parâmetros poderá variar um pouco. Para este arquivo, há 157 linhas de parâmetros comuns, 27 linhas para a primeira imagem, 27 linhas para a segunda imagem e a última linha que indica o final. O $\backslash$ Datalength : 20480 inicial, significa que o cabeçalho tem $20 \mathrm{~KB}$, cada imagem tem 524288 bytes ou $512 \mathrm{~KB}$, que correspondem a $512 \times 512 \times 2$ bytes. Como este arquivo contém duas imagens, seu tamanho será de $20 \mathrm{~KB}+2 \times 512 \mathrm{~KB}=1044 \mathrm{~KB}$. (Nota: $1 \mathrm{~K}=1024$ bits.)

\section{B.2 Convertendo os dados da imagem em alturas}

Por ocasião da captura da imagem, os dados são armazenados em valores de 16 bits, possibilitando a cada pixel um valor no range de $\pm 32.768\left(2^{16}=65.536\right)$. Para que as variações da superfície tirem o máximo proveito possível da resolução vertical, os dados deverão ser escalados do máximo ao mínimo deste range. Isto significa que não importa quão plana seja 
a superfície varrida, sua altura máxima será sempre um valor próximo de 32.768 e o mínimo próximo de -32.768 .

\section{B.2.1 Calculando os valores para as versões $4.3 x$ e $4.4 x$}

A escala da imagem pode ser obtida diretamente do parâmetro $\backslash$ Scansize, juntamente com sua unidade.

Para obter os dados em altura, precisamos de dois parâmetros, Sens. Zscan e Z scale. Por exemplo, suponhamos que o dado de determinado pixel seja 1000. As linhas com esses parâmetros fornecem o seguinte :

\Sens. Zscan : V $7.588637 \mathrm{~nm} / \mathrm{V}$

\2 : Zscale : V [Sens.Zscan $](0.006713765 \mathrm{~V} /$ LSB) 4.363947V

A altura em nanometros será dada pela equação :

$$
\text { Altura }=\frac{\text { dado }}{2^{16}} * \text { Sens. Zscan } * Z \text { scale }
$$

Que para este exemplo será :

$$
\text { Altura }=\frac{1000}{65536} * 7.588637 \mathrm{~nm} / \mathrm{V} * 4.363947 \mathrm{~V}=0.505 \mathrm{~nm} .
$$

O mesmo procedimento pode ser seguido para calcular a frequência, corrente, potencial, amplitude dos dados, etc. usando-se o $Z$ scale apropriado. 